\begin{abstract}
UNIVERSIDADE DE SÃO PAULO
FACULDADE DE FILOSOFIA, LETRAS E CIÊNCIAS HUMANAS

DEPARTAMENTO DE LETRAS MODERNAS

PROGRAMA DE PÓS-GRADUAÇÃO EM LÍNGUA, LITERATURA E CULTURA

ITALIANAS
\end{abstract}

Daniela Aparecida Vieira

A DIDATIZAÇÃO DE MATERIAIS AUTÊNTICOS PARA O ENSINO DO ITALIANO LÍNGUA ESTRANGEIRA

Versão corrigida

São Paulo

2012 


\author{
UNIVERSIDADE DE SÃO PAULO \\ FACULDADE DE FILOSOFIA, LETRAS E CIÊNCIAS HUMANAS \\ DEPARTAMENTO DE LETRAS MODERNAS \\ PROGRAMA DE PÓS-GRADUAÇÃO EM LÍNGUA, LITERATURA E CULTURA \\ ITALIANAS
}

Daniela Aparecida Vieira

\title{
A DIDATIZAÇÃO DE MATERIAIS AUTÊNTICOS PARA O ENSINO DO ITALIANO LÍNGUA ESTRANGEIRA
}

\author{
Versão corrigida
}

Dissertação apresentada ao Programa de PósGraduação em Língua, Literatura e Cultura Italianas do Departamento de Letras Modernas da Faculdade de Filosofia, Letras e Ciências Humanas da Universidade de São Paulo para obtenção do título de Mestre em Letras

Área de Concentração: Língua, Literatura e Cultura Italianas

Orientadora: Professora Dra. Paola Giustina Baccin 
Autorizo a reprodução e divulgação total ou parcial deste trabalho, por qualquer meio convencional ou eletrônico, para fins de estudo e pesquisa, desde que citada a fonte. 
A meus queridos pais, pelo amor, carinho, dedicação, apoio, incentivo, força, atenção e paciência. 


\section{AGRADECIMENTOS}

A Deus, por ter me dado tantos presentes nesta vida. Muito obrigada por tudo!

A Maria Luiza e Antonio, meus adorados pais, pelo amor, carinho e atenção que sempre me deram e pelo apoio incondicional em todas as etapas da minha vida.

À CAPES, por ter financiado parte de minha pesquisa.

À professora Paola Baccin, minha querida orientadora e minha primeira professora de italiano, por ter despertado em mim a paixão por essa língua, por ter me incentivado a fazer Mestrado, por ter me dado muito apoio e carinho, desde que nos conhecemos e por ter me ensinado muito, tanto na graduação quanto na pós-graduação.

À professora Fernanda Ortale, pelas aulas excelentes que me deu na pós-graduação, pela amizade, pelo carinho, pelo apoio e pelas sugestões e orientações preciosas que me deu desde 2010, ano em que fui sua aluna, até agora.

Ao professor José Simões, pela leitura cuidadosa de meu projeto de pesquisa e pelas sugestões que me deu na qualificação.

À professora Elisabetta Santoro, por ter sido uma ótima coordenadora do Italiano no Campus e por ter me ensinado muito no período em que trabalhei no IC.

À professora Cecilia Casini, por ter me ensinado muito no período em que fui sua aluna e por ter sempre confiado em mim.

À professora Giliola Maggio, pelas aulas de italiano tão divertidas que me deu.

À professora Lílian Passarelli, pelas aulas maravilhosas, na PUC-SP, que me fizeram ver o texto como um verdadeiro instrumento de ensino-aprendizagem de línguas.

À professora Regina Sellan, por ter me ajudado a desenvolver minhas primeiras reflexões quanto ao uso dos materiais autênticos.

Ao Marco Di Leonardo, meu querido "ragazzo", pelo amor, pelo carinho e pelo apoio que me deu, mesmo à distância, e por ter contribuído com o aumento da minha coleção de materiais autênticos.

Ao meu primo Cristiano Jesuíta, pelo apoio, pelo carinho, pelo incentivo e pelas conversas acadêmicas, literárias e filosóficas.

A meus colegas do Italiano no Campus, sem cujo apoio eu não teria conseguido aplicar meu questionário em todas as turmas do IC. Muito obrigada, Ana Paula de Souza, Carolina Varuzza, Cristiane Aragão, Eloína Ribeiro, Flávio Soares Júnior, Gloria Vinci, Graziele Altino, Ingrid Nardeli, Luciana Cammarota, Luciana Mauro, Tatiane Severino e Vinicio Corrias! 
A Flávio Soares Júnior, Tatiane Severino, Ana Paula de Souza, Marcel Vasconcelos, Rômulo de Souza e Ivair Castelan pela amizade, pelo carinho e pelo apoio.

A Alexandre Antoniazzi e Luciana Mauro, amigos muito especiais, pelo carinho, pelas trocas de experiências e pelo apoio.

A Darius Emrani, pela amizade, pelo carinho e por ter me convidado para ministrar uma oficina na livraria SBS.

À Cristiane Aragão, amiga querida que sempre se mostrou disposta a conversar sobre a minha pesquisa e sobre tantas "coisas da vida", além de sempre ter me dado muito apoio e carinho.

À Michele de Araújo Silva, minha confidente de todas as horas, amiga sempre presente na minha vida, nos momentos bons e ruins.

À Miriam Machado, minha colega e amiga, que me deu muito apoio e orientações no momento em que tentei solicitar uma licença na escola onde trabalho.

À Rita Maria Oliveira, amiga querida, que sempre torceu por mim.

À Vania Ortiz e Ana Cláudia da Silva, amigas queridas com quem estudei na graduação e que estão muito presentes na minha vida até hoje.

À Priscila e Carolina, minhas irmãs, pelo carinho e apoio.

A todos os meus amigos da EMEI onde trabalho há dez anos.

À Alice Reis e Simone Pereira, amigas queridas, pelo carinho, pelo apoio e pela força.

À Andrea Varella, Claudia Donegá e Maria Esther Dentello, amigas e colegas carinhosas e presentes na minha vida há anos.

A Paulo dos Santos Correa, por ter contribuído muito com o aumento do meu repertório musical italiano e por ter sido sempre muito atencioso comigo.

À Nádia Rodrigues e Sergio Cuzziol, meus primeiros alunos particulares, pela vontade de aprender e pela paciência com a minha inexperiência.

A meus queridos alunos e ex-alunos, especialmente a Adalberto Carpinelli, Amilkar Henrique, Beatriz Helena, Lígia Mies, Maria Celeste Mendes, Maria Célia Roque, Maria Teresa Ferriani, Mariana Magri, Nádia Mofatti, Oswaldo De Dominicis Júnior, Reinaldo Lindo e Sandro Detoni, por terem participado com entusiasmo e alegria (além de perguntas, dúvidas e sugestões) das aulas que construímos juntos e por terem me ajudado a ter certeza de que tem muito valor o meu trabalho.

A todas as pessoas que, direta ou indiretamente, participaram da minha vida nesses três anos e meio de Mestrado. Desculpem-me por não ter citado os nomes de todos vocês! 


\section{RESUMO}

VIEIRA, D.A. A didatização de materiais autênticos para o ensino do italiano língua estrangeira. 2012. 278 f. Dissertação (Mestrado) - Faculdade de Filosofia, Letras e Ciências Humanas da Universidade de São Paulo, São Paulo, 2012.

O principal objetivo desta dissertação é investigar, dos pontos de vista teórico e prático, o processo de didatização de textos autênticos no âmbito do ensino do italiano como língua estrangeira (LE). Quanto aos aspectos teóricos, procuramos apresentar as definições dos termos material didático, material autêntico e didatização. Procuramos, também, enfatizar a importância dos textos autênticos no processo de ensino-aprendizagem do italiano LE. Para alicerçar nosso trabalho, baseamo-nos na Teoria da Aprendizagem Significativa, de David Ausubel, na Teoria de Aquisição de Segunda Língua, de Stephen Krashen, e na Linguística Textual. A primeira consiste em uma teoria do âmbito da educação em geral e explica a importância dos conhecimentos prévios dos alunos no processo de ensino-aprendizagem. A segunda é uma teoria da área de aquisição/aprendizagem de línguas e interessa-nos, particularmente, pelo conceito de input compreensível. Já a terceira consiste em uma vertente da Linguística cujo objeto de estudo é o texto, que é considerado um instrumento resultante de processos cognitivos e de interações sociais. Essas três teorias têm bases cognitivistas e ofereceram-nos subsídios para a elaboração desta dissertação. Tentamos mostrar, com base em tais teorias, que a didatização de materiais autênticos pode ser uma maneira de oferecer insumo compreensível aos alunos e favorecer a aprendizagem significativa da língua-alvo por parte deles. No tocante aos aspectos práticos, por sua vez, realizamos uma pesquisa com os estudantes e com os professores do Italiano no Campus, curso de difusão cultural da Faculdade de Filosofia, Letras e Ciências Humanas da Universidade de São Paulo, no qual demos aulas de 2009 a 2011. Ademais, descrevemos algumas atividades que construímos com base em materiais autênticos e que utilizamos em uma classe de nível elementar (A1 do Quadro Comum Europeu de Referência para as Línguas). Essa pesquisa consiste em dois questionários: o que elaboramos para os alunos contém dezenove perguntas, e o que fizemos para os professores possui apenas quatro questões. A análise das respostas dos discentes, bem como a análise das respostas dos docentes parece ter evidenciado que os materiais que mais interessam aos alunos são, geralmente, aqueles que o professor mais utiliza em suas aulas. Os comentários dos aprendizes corroboram o que postulam muitos teóricos da pedagogia de línguas, isto é, que é importante que o professor de LE não use apenas o livro didático (LD) e que, para os discentes, a variedade de materiais e atividades pode tornar as aulas mais motivantes. A análise das respostas dos docentes parece ter mostrado que, na opinião dos professores, faz-se necessário utilizar outros materiais além do manual didático, mas que este ocupa, ainda, um lugar central no processo de ensino-aprendizagem do italiano LE. Com base nos dados analisados, parece-nos que essa centralidade deva-se, sobretudo, a três motivos: a obrigatoriedade do uso do LD; o fato de este ser uma referência para os aprendizes; e a praticidade desse instrumento aliada à falta de tempo que o professor tem para selecionar outros materiais e elaborar suas próprias atividades.

Palavras-chave: italiano língua estrangeira, materiais autênticos, didatização, input compreensível, aprendizagem significativa. 


\begin{abstract}
VIEIRA, D.A. The didactization of authentic materials for the teaching of Italian as foreign language. 2012. 278 p. Master's Thesis - Faculty of Philosophy, Languages and Human Sciences at the University of São Paulo, São Paulo, 2012.
\end{abstract}

The main purpose of this thesis is to investigate, from the theoretical and practical point of view, the process of didactization of authentic texts in the teaching of Italian as foreign language (FL). Regarding the theoretical aspects, we have attempted to present the definition of the terms didactic material, authentic material and didactization. We also have sought to emphasize the importance of authentic texts in the process of teaching-learning Italian as a foreign language. In order to establish a foundation for our work, we have based it on David Ausubel's Theory of Meaningful Learning, on Stephen Krashen's Theory of Second Language Acquisition, and on Textual Linguistics. The first consists of a theory of the scope of education in general and explains the importance of the student's previous knowledge in the teaching-learning process. The second is a theory in acquisition/learning of languages and interests us especially because of the concept of comprehensible input. The latter consists of a branch in Linguistics whose purpose is the study of the text, which is considered an instrument that results from cognitive processes and social interactions. These three theories have cognitivist bases and provide us with tools for the development of this work. We have tried to show, based on such theories, that the didactization of authentic materials can be a way to provide comprehensible input to the students and to favor the meaningful learning of the target-language by them. Regarding the practical aspects, we have conducted a research with the students and teachers of Italian in the campus, the cultural dissemination course at the Faculty of Philosophy, Languages and Human Sciences at the University of São Paulo, in which we have taught from 2009 to 2011. Also, we have described some activities we developed that were based on authentic materials, which we used in an elementary level class (A1 from the Common European Framework of Reference for Languages). This research comprises of two questionnaires: the one with the students includes nineteen questions and the one conducted with the teachers includes four questions. The analysis of the students' answers and the analysis of the teachers' answers show that the materials that most interest the students are the ones used the most by the teachers in classes. The apprentices' comments corroborate what is postulated by many theoreticians in language teaching, i.e., it is important for the FL teacher not to be restricted to the textbook, and for the student, the variety of materials and activities might render the classes more captivating. The analysis of the teachers' answers seems to show that in their opinion it is necessary to use other materials apart from the teaching manual, which still occupies a central position in the process of teaching-learning Italian as foreign language. Based on the analyzed data, it seems to us that this centrality has three reasons: the obligation to use the textbook; the fact that the textbook is a reference for the apprentices; and the practical aspect of this tool connected to the teacher's lack of time to choose other materials and create their own activities.

Keywords: Italian as foreign language, authentic materials, didactization, comprehensible input, meaningful learning. 


\section{RIASSUNTO}

VIEIRA, D. A. La didattizzazione di materiali autentici per l'insegnamento dell'italiano lingua straniera. 2012. 278 f. Tesi (Master) - Facoltà di Filosofia, Lettere e Scienze Umane dell’Università di San Paolo, San Paolo, 2012.

Il principale scopo di questa tesi è quello di investigare, dai punti di vista teorico e pratico, il processo di didattizzazione di testi autentici nell' ambito dell'insegnamento dell'italiano come lingua straniera (LS). Riguardo agli aspetti teorici, abbiamo cercato di presentare le definizioni dei termini materiale didattico, materiale autentico e didattizzazione. Abbiamo cercato inoltre di enfatizzare l'importanza dei testi autentici nel processo di insegnamentoapprendimento dell'italiano LS. Per sostenere la nostra tesi ci siamo basati sulla Teoria dell'Apprendimento Significativo, di David Ausubel, sulla Teoria dell'Acquisizione della Seconda Lingua, di Stephen Krashen e sulla Linguistica Testuale. La prima consiste in una teoria dell'ambito dell'educazione in generale e spiega l'importanza delle conoscenze pregresse degli allievi nel processo di insegnamento-apprendimento. La seconda è una teoria dell'area dell'acquisizione/apprendimento delle lingue e ci interessa particolarmente per il concetto di input comprensibile. La terza invece consiste in un filone della Linguistica il cui oggetto di studio è il testo, che viene considerato uno strumento risultante da processi cognitivi e da interazioni sociali. Queste tre teorie hanno basi cognitive e ci hanno offerto sussidi all'elaborazione di questa tesi. Abbiamo provato a dimostrare, in base a queste teorie, che la didattizzazione di materiali autentici può offrire un input comprensibile agli studenti e favorire l'apprendimento significativo della LS da parte loro. Per quanto riguarda gli aspetti pratici, invece, abbiamo fatto un'indagine a cui hanno partecipato gli studenti e gli insegnanti dell'Italiano nel Campus, corso libero della Facoltà di Filosofia, Lettere e Scienze Umane dell'Università di San Paolo, in cui abbiamo dato lezioni dal 2009 al 2011. Inoltre, abbiamo descritto alcune attività che abbiamo costruito in base ai materiali autentici e che abbiamo utilizzato in una classe di livello A1 del Quadro Comune Europeo di Riferimento per le Lingue. Questa indagine consiste in due questionari: quello che abbiamo elaborato per gli alunni contiene diciannove domande e quello che abbiamo fatto per gli insegnanti ne ha soltanto quattro. Pare che l'analisi delle risposte dei discenti nonché l'analisi delle risposte dei docenti abbia evidenziato che i materiali che interessano di più agli studenti sono di solito quelli che l'insegnante utilizza di più nelle sue lezioni. I commenti degli apprendenti ribadiscono quello che sostengono molti teorici della glottodidattica, cioè che è importante che l'insegnante di LS non usi soltanto il libro didattico (LD) e che per i discenti la varietà dei materiali e delle attività può rendere più motivanti le lezioni. Pare che l'analisi delle risposte dei docenti abbia mostrato che nella loro opinione è necessario utilizzare altri materiali oltre al manuale didattico ma che esso occupa ancora un posto centrale nel processo di insegnamento-apprendimento dell'italiano LS. In base ai dati analizzati ci sembra che questa centralità sia dovuta soprattutto a tre motivi: l'obbliegatorietà dell'uso del LD; il fatto che esso sia un riferimento per gli apprendenti; e la praticità di questo strumento abbinata alla mancanza di tempo che l'insegnante ha per selezionare altri materiali e elaborare le sue proprie attività.

Parole-chiave: italiano lingua straniera, materiali autentici, didattizzazione, input comprensibile, apprendimento significativo. 


\section{LISTA DE GRÁFICOS}

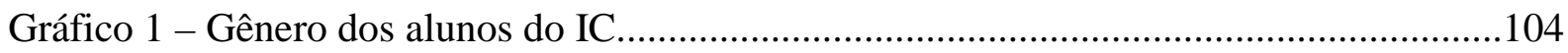

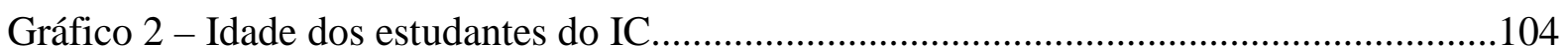

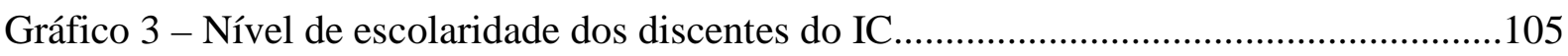

Gráfico 4 - Áreas de formação dos aprendizes do IC...........................................................105

Gráfico 5 - Profissões dos alunos do Italiano no Campus......................................................106

Gráfico 6 - Nível do Italiano no Campus cursado pelos aprendizes......................................107

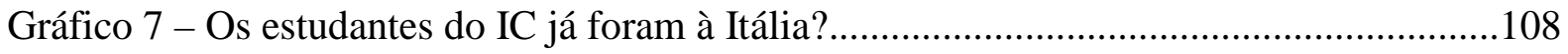

Gráfico 8 - Quanto tempo os estudantes do IC que já foram à Itália ficaram lá?..................109

Gráfico 9 - Os discentes gostam das aulas de italiano? ....................................................110

Gráfico 10 - Do que os alunos do IC mais gostam nas aulas de italiano?............................111

Gráfico 11 - Os estudantes do IC têm contato com a língua-alvo fora das aulas?.................115

Gráfico 12 - Formas de contato que os alunos do IC estabelecem com o italiano fora da sala

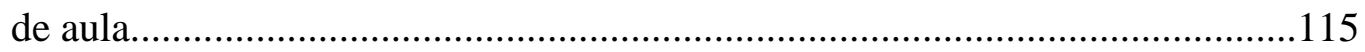

Gráfico 13 - Quais atividades de compreensão oral os alunos do IC preferem?...................118

Gráfico 14 - Atividades que, segundo os discentes do IC, não foram realizadas nas aulas que eles já tiveram.....

Gráfico 15-De quais atividades de compreensão escrita os estudantes do IC mais gostam?

Gráfico 16-Atividades de compreensão escrita que, segundo os alunos, não foram trabalhadas nas aulas de italiano do IC.

Gráfico 17 - Atividades de produção oral das quais os estudantes do IC mais gostam

Gráfico 18 - Atividades de produção oral as quais, segundo os discentes, não foram utilizadas em suas aulas de italiano LE...

Gráfico 19 - Atividades de produção escrita preferidas pelos estudantes do IC.

Gráfico 20 - Atividades de produção escrita que, de acordo com os alunos do IC, não foram utilizadas nas aulas. .125

Gráfico 21 - Atividades gramaticais de que os alunos do IC mais gostam...... 126

Gráfico 22 - Atividades gramaticais que, de acordo com os aprendizes, não foram aplicadas nas aulas do IC.

Gráfico 23 - Atividades lexicais de que os estudantes do IC mais gostam. 128

Gráfico 24 - Atividades lexicais que, segundo os estudantes do IC, não foram trabalhadas nas 
aulas

Gráfico 25 - Atividades lúdicas preferidas pelos estudantes do IC

Gráfico 26 - Atividades lúdicas que, segundo os discentes, não foram usadas nas aulas......131

Gráfico 27 - De acordo com os aprendizes do IC, há alguma atividade que o professor deveria usar (mais) em sala de aula?

Gráfico 28 - Atividades que, segundo os discentes do IC, deveriam ser (mais) utilizadas nas aulas

Gráfico 29 - Os estudantes do IC gostam do livro Linea diretta?

Gráfico 30 - Opiniões favoráveis dos alunos quanto ao LD adotado no Italiano no Campus.

Gráfico 31 - Opiniões desfavoráveis dos aprendizes quanto ao LD adotado no Italiano no Campus.

Gráfico 32 - Materiais assinalados como primeira opção pelos alunos do IC

Gráfico 33 - Materiais que, segundo os alunos do IC, não foram usados nas aulas.

Gráfico 34 - Segundo os alunos do IC, há algum material que o professor/monitor deveria utilizar (mais) na sala de aula?

Gráfico 35 - Materiais que, de acordo com os aprendizes, deveriam ser (mais) usados nas aulas do Italiano no Campus

Gráfico 36 - Quais materiais os professores costumam utilizar nas aulas do Italiano no Campus? 


\section{LISTA DE TABELAS E FIGURAS}

Tabela 1 - Objetivos de cada pergunta do questionário respondido pelos alunos do IC........100

Tabela 2 - Perguntas do jogo "Lupo Alberto"

Figura 1 - Modelo da operação global do ensino de línguas proposto por Almeida Filho......40

Figura 2 - O tabuleiro do jogo de percurso que confeccionamos........................................181

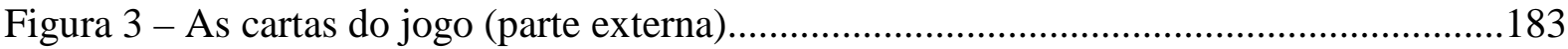

Figura 4 - A primeira historinha que trabalhamos com nossa turma..................................185

Figura 5 - A segunda história do lobo Alberto trabalhada com nossos alunos......................188

Figura 6 - A terceira e última história utilizada com nossos aprendizes..............................191 


\section{SUMÁRIO}

INTRODUÇÃO.

\section{MATERIAIS AUTÊNTICOS: FONTES DE INPUT PARA A APRENDIZAGEM SIGNIFICATIVA DE UMA LÍNGUA ESTRANGEIRA. 8}

1.1. Textos didáticos e textos autênticos: algumas definições...............................................

1.2. Algumas polêmicas quanto à utilização de textos didáticos nas aulas de LE....................14

1.3. A importância da utilização de materiais autênticos no ensino de línguas

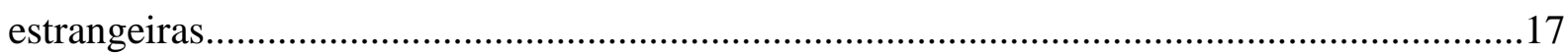

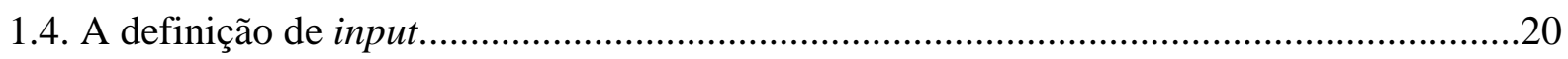

1.5. Aquisição e aprendizagem: processos complementares................................................27

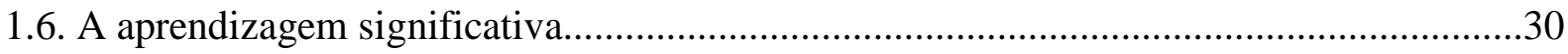

2. A PRESENÇA (OU AUSÊNCIA) DE MATERIAIS AUTÊNTICOS EM ALGUNS DOS PRINCIPAIS MÉTODOS E ABORDAGENS DE ENSINO DE LÍNGUAS

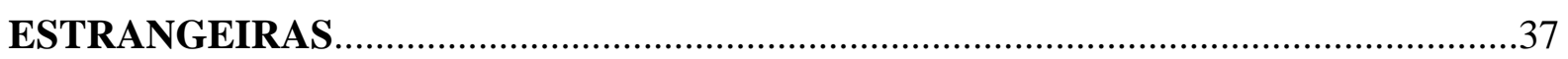

2.1. Abordagem, método e técnica - algumas definições.....................................................37

2.2. A utilização (ou não) de textos autênticos nos métodos tradicionais de ensino de línguas

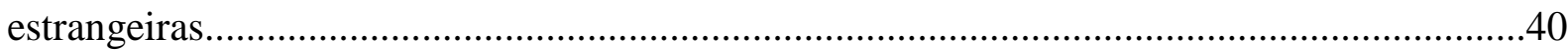

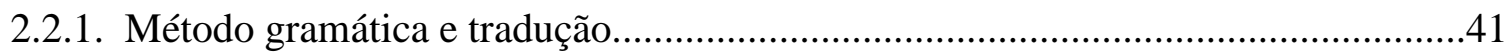

2.2.2. Método da leitura (Reading method) ...................................................................

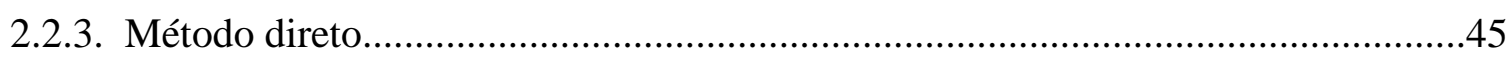

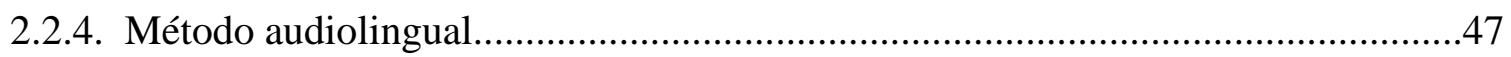

2.3. A presença (ou ausência) de materiais autênticos nos métodos alternativos de ensino de

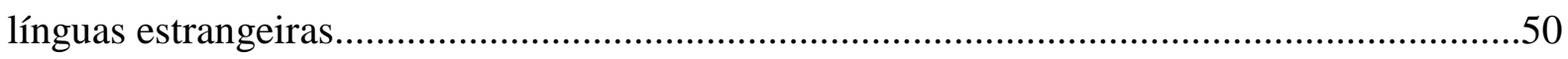

2.3.1. Método comunitário (CLL - Community Language Learning)...............................51

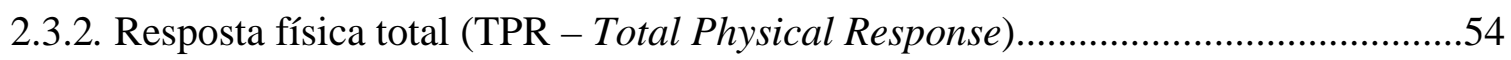

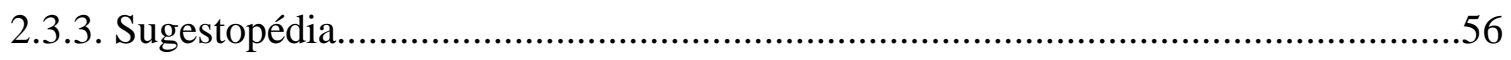

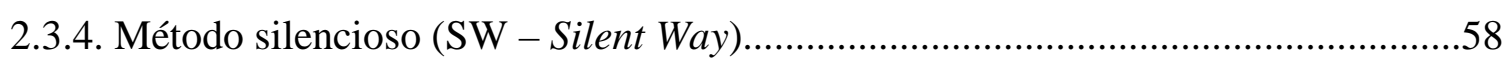

2.4. A utilização de materiais autênticos na abordagem comunicativa...................................61 
3.1. O que é didatização?. .68

3.2. Algumas técnicas de didatização de materiais autênticos .70

3.2.1. Técnicas didáticas para o desenvolvimento de habilidades e competências.............71

3.2.2. Técnicas didáticas sob uma perspectiva neurolinguística....................................76

3.2.3. As técnicas didáticas e a aprendizagem significativa da língua-alvo......................78

3.3. Alguns conceitos da Linguística Textual importantes no processo de didatização de materiais autênticos.

3.3.1. Texto e discurso. 84

3.3.2. Gênero textual e tipo textual. .86

3.3.3. Suporte. .89

3.4. Textos autênticos, conceitos da Linguística Textual e didatização. .89

3.4.1. Os textos autênticos orais no ensino de LE .93

3.4.2. O ensino de línguas estrangeiras e os textos autênticos escritos. .95

\section{O PAPEL DOS MATERIAIS AUTÊNTICOS E DIDÁTICOS NO PROCESSO DE ENSINO-APRENDIZAGEM DO ITALIANO LE: O PONTO DE VISTA DOS ALUNOS 98}

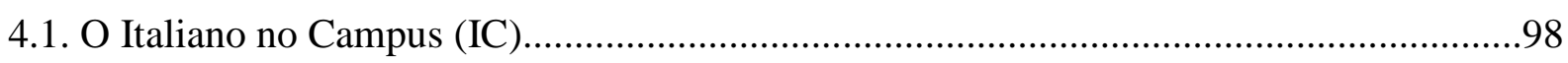

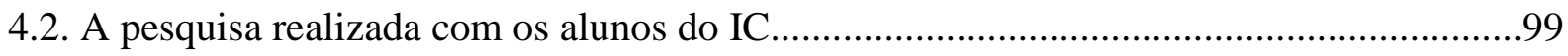

4.2.1. O perfil dos aprendizes do Italiano no Campus.......................................................103

4.2.2. Motivos pelos quais os alunos querem estudar italiano.......................................107

4.2.3. A quantidade de alunos que já foi à Itália...............................................................108

4.2.4. Razões pelas quais os aprendizes do IC gostam das aulas de italiano....................110

4.2.5. Aspectos de que os alunos gostam e de que não gostam nas aulas de italiano.

4.2.6. Aspectos que os discentes consideram que poderiam ser melhores nas aulas de italiano LE.

4.2.7. Os alunos do IC e o contato com a língua italiana fora da sala de aula...... 114

4.3. As atividades preferidas pelos estudantes do IC 116

4.3.1. As preferências dos aprendizes quanto às atividades de compreensão oral. 118

4.3.2. As opiniões dos estudantes no tocante às atividades de compreensão escrita. 120

4.3.3. As preferências dos discentes no tocante às atividades de produção oral 122

4.3.4. As atividades de produção escrita prediletas dos aprendizes. 
4.3.5. As opiniões dos discentes no que concerne às atividades gramaticais. 126

4.3.6. As percepções dos aprendizes quanto às atividades lexicais 128

4.3.7. As atividades lúdicas preferidas pelos alunos do Italiano no Campus.

4.3.8. As atividades que os alunos do Italiano no Campus prefeririam que o professor utilizasse (mais) nas aulas.

4.4. Opiniões dos alunos quanto ao livro didático adotado no IC.

4.5. Os materiais de que os estudantes do Italiano no Campus mais gostam.

4.5.1. Os materiais que o professor deveria utilizar (mais) nas aulas de italiano: as opiniões dos discentes.

4.6. Os materiais utilizados nas aulas do Italiano no Campus - as opiniões dos professores

\section{OS MATERIAIS AUTÊNTICOS NA SALA DE AULA DE ITALIANO LE: DESCRIÇÃO E APLICAÇÃO DE ALGUMAS ATIVIDADES.

5.1. A utilização de materiais autênticos em uma de nossas turmas iniciantes no estudo do italiano língua estrangeira. 150

5.2. A canção nas aulas de italiano LE 152

5.2.1. As duas canções trabalhadas com nossa turma de nível I. 154

5.3. A escolha do gênero textual folheto de supermercado. 156

5.3.1. A didatização de um folheto de supermercado.

5.3.2. A aplicação das atividades elaboradas com base no gênero textual folheto de supermercado: relatos de prática. 168

5.4. A escolha do gênero textual história em quadrinhos. 175

5.4.1. A didatização de algumas histórias em quadrinhos: a seleção dos textos e a definição dos objetivos.

5.4.2. A didatização de algumas histórias do lobo Alberto - as atividades propostas e alguns relatos de prática. 


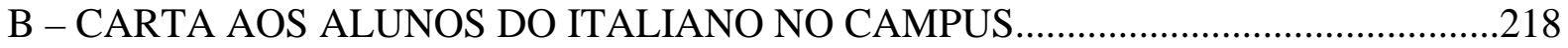

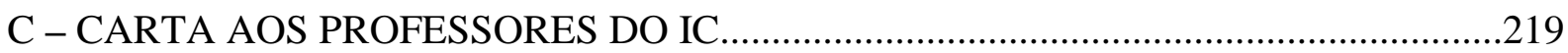

D - ATIVIDADES BASEADAS NA CANÇÃO “LAURA NON C'È”...............................220

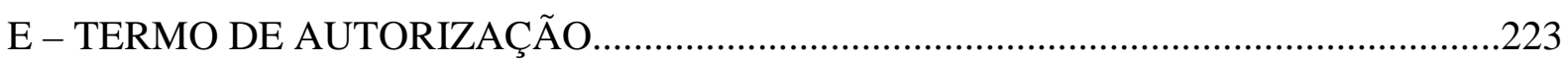

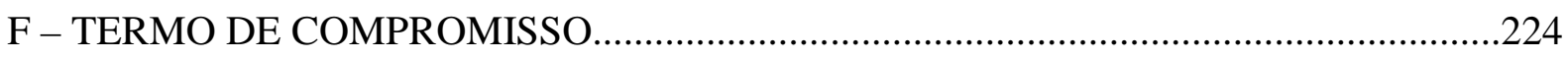

G - TRADUÇÃO DAS PERGUNTAS DO JOGO “LUPO ALBERTO”.............................225

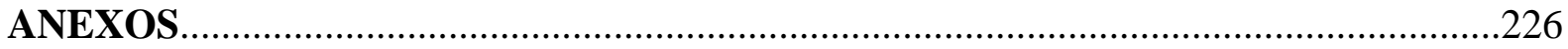

A - ATIVIDADES BASEADAS NA CANÇÃO “CI VUOLE UN FIORE”, RETIRADAS

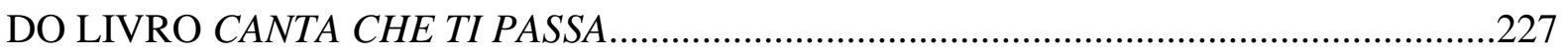

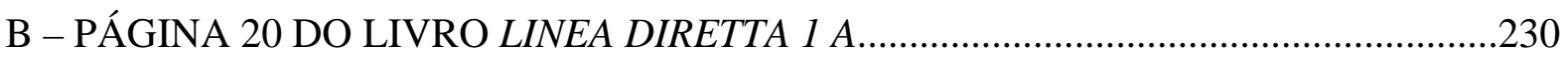

C - FOLHETO DO SUPERMERCADO CARREFOUR ITALIANO..................................231

D - PÁGINAS INICIAIS DO LIVRO LUPO ALBERTO. T. V. B. LUPO! - ENTREVISTA A SILVER E DESCRIÇÃO DOS PERSONAGENS DO MUNDO

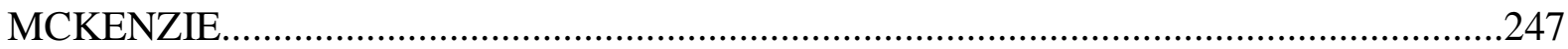




\section{INTRODUÇÃO}

A ideia de desenvolvermos uma pesquisa sobre a didatização ${ }^{1}$ de materiais autênticos para o ensino do italiano língua estrangeira (LE) surgiu em 2005, ano em que em que começamos a lecionar italiano, mas só se concretizou no final de 2008, quando, finalmente, conseguimos escrever nosso projeto de pesquisa e submetê-lo ao processo seletivo para ingresso no Mestrado em Língua, Literatura e Cultura Italianas da Faculdade de Filosofia, Letras e Ciências Humanas da Universidade de São Paulo (FFLCH-USP).

Decidimos pesquisar esse tema pelos seguintes motivos:

- o descontentamento com o trabalho com um determinado livro didático: em uma das instituições de ensino onde trabalhávamos, usava-se (e ainda usa-se) In italiano ${ }^{2}$, um livro didático que apresenta atividades que focam, quase exclusivamente, aspectos gramaticais da LE e o faz, basicamente, sob a forma de exercícios estruturais muito mecânicos, isto é, não propõe atividades motivantes, nem do ponto de vista do professor, nem do aluno. Ao utilizá-lo com estudantes do nível elementar (A1, de acordo com a nomenclatura do Quadro Comum Europeu de Referência para as Línguas), os aprendizes sempre se queixavam daquele tipo de exercício, cuja feitura exigia deles, quase sempre, apenas a inserção de palavras em espaços em branco, ou a transformação de frases isoladas. Quando fazíamos uso apenas do manual didático nas aulas, tínhamos a impressão de que, como as atividades eram muito "previsíveis" e repetitivas, tornavam-se bastante cansativas para os aprendizes (e para nós). Mas, nessa instituição, algumas vezes, podíamos utilizar outros materiais, além de tal livro didático, e, nessas ocasiões, percebíamos que o nível de motivação aumentava na sala de aula. Ademais, em outras instituições de ensino de idiomas, pudemos usar livros didáticos que nos pareciam bastante interessantes, pois, entre outros motivos, apresentavam excertos de textos autênticos;

- um grande interesse pessoal que tínhamos por um material autêntico específico: a canção. Como muitos alunos sempre declaram que gostam da música italiana, sempre acreditamos que ela pudesse ser utilizada como um valioso instrumento no processo de ensino-aprendizagem do italiano. Sempre acreditamos nisso, também, porque nós,

\footnotetext{
${ }^{1} \mathrm{O}$ termo didatização é o equivalente da palavra italiana didattizzazione. Esse termo é utilizado, na literatura da área da pedagogia de línguas, tanto na língua portuguesa quanto na língua italiana, embora seja mais frequentemente usado nesta do que naquela.

${ }^{2} \mathrm{Na}$ verdade, In italiano é uma gramática pedagógica utilizada como livro didático em algumas instituições de ensino, como a escola de idiomas onde lecionávamos.
} 
como aprendizes dessa língua, adquirimos muitos conhecimentos gramaticais, lexicais e, inclusive, culturais, a partir do trabalho com canções italianas. Nossa ideia inicial era a de fazer um projeto de pesquisa referente apenas ao uso da canção como material autêntico a ser usado no ensino do italiano LE, mas, depois, ao conversar com a nossa orientadora, professora Dra. Paola Baccin, decidimos expandir o tema, uma vez que a canção, como material autêntico, já tem sido muito explorada por pesquisadores e autores de livros didáticos;

- a nossa dificuldade pessoal em trabalhar com o material autêntico: a vontade de fazer uso do material autêntico para "deixar a língua-alvo menos artificial" (cf. WIDDOWSON, 1978, p.112) e, também, o fato de termos pouca experiência no âmbito do ensino de LE fizeram com que nos déssemos conta de que seria necessário aprofundar o estudo do tema em questão, para realmente apropriarmo-nos dele e aprendermos a utilizar essa categoria de material de forma a atender aos interesses e necessidades de nossos alunos.

Esses foram os motivos de ordem pessoal que nos levaram a escolher a didatização de textos autênticos como objeto de investigação teórica e prática. O tema que escolhemos não tem, no entanto, apenas relevância de caráter pessoal; ele também é importante do ponto de vista teórico, visto que, no âmbito específico do ensino do italiano como LE, há poucos estudos referentes à didatização de materiais autênticos. Portanto, esperamos que nosso trabalho possa representar uma contribuição, ainda que modesta, a essa área.

Na presente dissertação, nosso objetivo geral consiste em investigar, dos pontos de vista teórico e prático, o processo de didatização de textos autênticos. Este trabalho divide-se em cinco capítulos: os três primeiros são de caráter teórico, e os dois últimos tematizam a prática; isto é, nos capítulos 1,2 e 3 tratamos de teorias que embasam nossa pesquisa (a Teoria de Aquisição de Segunda Língua, de Krashen; a Teoria da Aprendizagem Significativa, de Ausubel; e a Linguística Textual), e nos capítulos 4 e 5 procuramos relacioná-las à prática didático-pedagógica, discorrendo sobre o ponto de vista dos alunos quanto aos materiais autênticos e didáticos e descrevendo o processo de didatização de textos autênticos. A seguir, apresentamos detalhadamente cada capítulo. 
No capítulo 1, nosso objetivo consiste em mostrar a importância da utilização de materiais autênticos nas aulas de língua estrangeira (LE) ${ }^{3}$, com enfoque, particularmente, nas aulas de italiano LE, pois esse é o nosso contexto de trabalho docente.

$\mathrm{Na}$ maior parte da bibliografia referente aos materiais autênticos, encontramos os termos texto autêntico e material autêntico empregados, quase sempre, como sinônimos, o que nos leva a pensar que, para muitos teóricos da área da pedagogia de línguas ${ }^{4}$, parece não haver grande diferença de significado entre ambos. Por isso, na dissertação que aqui se apresenta, utilizaremos os dois termos do mesmo modo que o fazem tais teóricos, isto é, consideraremos que ambas as expressões designam o mesmo objeto.

Para ressaltar a importância do uso dos materiais autênticos, discorremos, inicialmente, sobre as definições dos termos texto didático e texto autêntico, caracterizando-os como as duas principais categorias de materiais que são empregados no ensino de uma língua-alvo.

Quanto ao primeiro termo, não há, entre os diversos autores, controvérsias quanto à sua definição. Todavia, apesar de o termo material didático possuir, praticamente, uma definição unívoca, existem muitas polêmicas concernentes ao uso do representante clássico desse tipo de material: o livro didático (LD). Há autores, como Widdowson (1978), por exemplo, que não são muito favoráveis à utilização do LD, em virtude da artificialidade da maioria dos textos que o integra. Mas, para alguns autores, como Mezzadri (2003), o uso desse material é necessário, pois permite que o aluno tenha um percurso de estudo organizado e autônomo.

Já quanto à definição do segundo termo, há muitas controvérsias entre os diferentes teóricos que se dedicaram ao seu estudo; ou seja, o termo material autêntico não possui uma única definição. Em nossa dissertação, apresentamos as definições

\footnotetext{
${ }^{3}$ Há teóricos que utilizam os termos língua estrangeira (LE) e segunda língua (L2) como sinônimos. Há, também, autores que mantêm a distinção apresentada pela literatura da área de glotodidática, segundo a qual, o termo língua estrangeira refere-se a uma língua estudada e aprendida em espaços onde ela não tem qualquer estatuto sociopolítico, e segunda língua diz respeito a uma língua não materna e oficial utilizada e aprendida dentro de um território em que ela tem uma função reconhecida. Para o objetivo central do presente trabalho, a diferença entre ambos os termos parece ser significativa, visto que nossa pesquisa situa-se, especificamente, no âmbito do ensino-aprendizagem da língua italiana no Brasil. Por isso, para referirmo-nos à língua que é nosso objeto de ensino e pesquisa, empregaremos apenas o termo língua estrangeira (LE).

${ }^{4} \mathrm{Em}$ italiano, o termo mais frequentemente utilizado para pedagogia de línguas é "glottodidattica". Embora exista, em português, o termo glotodidática, este é pouco usado. Tanto na língua portuguesa quanto na italiana, emprega-se, frequentemente, o termo didática das línguas estrangeiras ("didattica delle lingue straniere") como sinônimo dos termos já mencionados. Assim, na presente dissertação, usaremos todos esses termos como equivalentes um do outro.
} 
propostas por Coste (1970), Wilkins (1976), Widdowson (1978), Breen (1985), Nunan (1992), Pallotti (1998), entre outros autores.

Por não haver uma definição unívoca para o termo em questão, e, tendo em vista a necessidade de explicitar nosso objeto de estudo, pareceu-nos necessário, no trabalho que aqui se apresenta, elaborar uma definição para esse termo. Nossa definição baseia-se nas que foram propostas por alguns desses teóricos e será exposta no primeiro capítulo.

Depois de esclarecer os conceitos de material didático e de material autêntico, procuramos enfatizar a importância da utilização desse último em nossas aulas de LE. Para tanto, apoiamo-nos nos conceitos de input compreensível, de Krashen (1982) e de aprendizagem significativa, de Ausubel (1968), tentando mostrar algumas relações entre ambos os conceitos e a didatização de textos autênticos para o ensino de uma língua-alvo.

No capítulo 2, nosso objetivo principal consiste em analisar a presença (ou ausência) dos materiais autênticos em alguns dos principais métodos e abordagens de ensino de línguas estrangeiras. Para realizar essa análise, procuramos, primeiramente, situar, no âmbito da pedagogia de línguas, os materiais que constituem objeto de nosso estudo; por isso, no capítulo em questão, abordamos, de modo muito sucinto, com base em Anthony (1963), Richards e Rodgers (1986), Borneto (1998), Balboni (1995) e Almeida Filho (1993), as diferenças entre os conceitos de abordagem, método e técnica, procurando mostrar que a escolha de um determinado tipo de material, em detrimento de outro, está diretamente concatenada à abordagem de ensino do professor de LE.

Em seguida, discorremos acerca da utilização (ou não) de materiais autênticos nos métodos tradicionais de ensino de línguas mais conhecidos, a saber: o método gramática e tradução, o reading method, o método direto e o método audiolingual. Para tanto, descrevemos brevemente cada um deles, em seus aspectos didáticos e linguísticos, baseando-nos em Borneto (1998), Larsen-Freeman (1997), Richards e Rodgers (1986) e Piva (2000). Dentro de cada descrição, procuramos abordar a questão dos materiais empregados nesses métodos, com o intuito de verificar em que medida os materiais autênticos são usados (ou não) em cada um deles.

Também no capítulo 2, utilizando algumas das referências teóricas acima mencionadas, buscamos investigar a presença (ou ausência) dos materiais autênticos nos métodos alternativos de ensino de LE. Para isso, fizemos uma descrição sucinta dos seguintes métodos: Community Language Learning, Total Physical Response, Sugestopédia e Silent Way. No interior de cada descrição, discorremos sobre os materiais empregados em cada um desses métodos. 
Além disso, baseando-nos em Richards e Rodgers e em Scalzo (1998), apresentamos algumas breves reflexões sobre a utilização de materiais autênticos na abordagem comunicativa.

Para encerrarmos o segundo capítulo, com base em todos os teóricos supracitados, apresentamos nossas conclusões quanto à análise da presença/ausência dos materiais autênticos nos principais métodos e abordagens de ensino de línguas estrangeiras; essas conclusões não pretendem ter caráter definitivo, uma vez que, como dissemos, fizemos breves descrições dos métodos anteriormente mencionados, e não um estudo exaustivo e aprofundado sobre cada um deles. Tais considerações finais, portanto, são reflexões a respeito da utilização dos materiais autênticos, objeto de nossa pesquisa.

No capítulo 3, pretendemos explicar o processo de didatização de materiais autênticos. Para tanto, primeiramente, discorremos sobre o conceito de didatização, procurando explicitar que, por não termos encontrado, na literatura consultada, uma definição clara para esse termo, tivemos de propor uma definição para ele.

Em seguida, discorremos sobre algumas técnicas didáticas, situando-as no esquema hierárquico proposto por Anthony (1963) e reiterado por Almeida Filho (1993), Balboni (1995) e Borneto (1998). Mostramos, também, algumas compilações de técnicas organizadas por três teóricos italianos: Balboni (1995), Mezzadri (2003) e Danesi (1998). Os agrupamentos de técnicas propostos pelos dois primeiros autores foram feitos com base no desenvolvimento de habilidades e competências. Já a compilação organizada pelo terceiro diz respeito a aspectos neurolinguísticos.

Apresentadas e comentadas essas listas de técnicas, procuramos identificar aquelas que estão mais diretamente relacionadas ao trabalho com os conhecimentos prévios dos alunos, isto é, aquelas que mais podem nos auxiliar a favorecer a aprendizagem significativa (conceito de Ausubel) da língua estrangeira por parte de nossos discentes.

Após tentar explicitar algumas relações entre o processo de aprendizagem significativa e as técnicas didáticas, discorremos acerca de alguns conceitos da Linguística Textual (LT) importantes no processo de didatização de materiais autênticos.

Tendo em vista que não há apenas uma Linguística Textual, procuramos esclarecer que optamos pela LT de base sociocognitiva, porque essa teoria linguística está em consonância com outras duas teorias que embasam o trabalho que aqui se apresenta e sobre as quais discorremos no capítulo 1: a Teoria de Aquisição de Segunda Língua, de Krashen e a Teoria da Aprendizagem Significativa, de Ausubel. 
Os conceitos da LT de que tratamos no terceiro capítulo são estes: texto, discurso, gênero textual, tipo textual e suporte. Decidimos discorrer sobre eles, pois cada um desses conceitos está ligado ao material autêntico, que é nosso objeto de investigação teórica e prática.

Esclarecidos esses conceitos, baseando-nos em Begotti (s. d.), Spinelli (2003) e Marcuschi (2008) apresentamos alguns agrupamentos possíveis para os materiais autênticos e algumas reflexões concernentes à utilização de textos autênticos orais e escritos no processo de ensino-aprendizagem de uma língua-alvo.

No capítulo 4, tendo em vista que os alunos são o centro do processo de ensinoaprendizagem, nosso escopo principal consiste em investigar o ponto de vista deles quanto aos materiais autênticos e didáticos. Para realizar tal investigação, elaboramos um questionário com dezenove perguntas referentes a diversos aspectos envolvidos no processo de ensino-aprendizagem de línguas estrangeiras e, em particular, do italiano LE e solicitamos que os estudantes do Italiano no Campus (curso de difusão cultural da Faculdade de Filosofia, Letras e Ciências Humanas da Universidade de São Paulo) respondessem todas as questões. Solicitamos, ademais, aos professores desse curso que também respondessem algumas questões.

Como nosso objeto de estudo consiste nos materiais, apresentamos e analisamos apenas as respostas dos alunos às perguntas que, direta ou indiretamente, dizem respeito a esses instrumentos utilizados nas aulas de LE.

Após mostrarmos uma análise dos dados concernentes às opiniões dos aprendizes e uma interpretação possível para as suas respostas, apresentamos uma brevíssima análise das respostas dos professores do Italiano no Campus (IC) quanto aos materiais utilizados nas aulas. No final do quarto capítulo, procuramos comparar as opiniões dos docentes às dos discentes.

No capítulo 5, por sua vez, tentamos mostrar, na prática, alguns aspectos teóricos tratados nos capítulos anteriores, descrevendo o processo de didatização de dois materiais autênticos: o folheto de supermercado e a história em quadrinhos. Trabalhamos esses dois gêneros textuais junto a nossos alunos de uma turma do nível I do Italiano no Campus.

Obviamente, utilizamos outros textos autênticos com todas as nossas classes do IC, mas optamos por descrever detalhadamente apenas o processo de didatização desses dois gêneros trabalhados com um grupo de nível I, porque nos interessa tentar mostrar que o trabalho com esses valiosos instrumentos de ensino-aprendizagem da LE pode ser 
realizado em qualquer estágio de estudo da língua-alvo, inclusive no primeiro nível de aprendizagem linguística.

A escolha desses dois gêneros e as atividades que elaboramos com base neles deram-se em função dos conteúdos que os discentes precisavam aprender, porque faziam parte do programa do nível I do Italiano no Campus e, também, em função dos interesses que os estudantes demonstraram durante o semestre.

Ao discorrer sobre o processo de didatização, procuramos mostrar as etapas que fazem parte dele, a saber: a definição do gênero textual a ser didatizado, a escolha do texto pertencente a tal gênero, a definição dos objetivos a serem atingidos pelos alunos a partir do material trabalhado, a preparação de atividades com base neste, a aplicação dessas atividades e a avaliação de tal aplicação.

Em suma, no último capítulo de nossa dissertação, procuramos ilustrar, na prática, a complexidade do processo de didatização de materiais autênticos no contexto específico de ensino-aprendizagem do italiano LE.

Concluídos os cinco capítulos, apresentamos nossas considerações finais, elaboradas a partir dos aspectos teóricos e práticos tratados nesta dissertação. Essas considerações finais sintetizam nosso trabalho e têm um caráter reflexivo: são reflexões que construímos, ao longo dos três anos e meio que dedicamos à realização de nossa pesquisa de Mestrado, com base nos postulados teóricos que embasaram o trabalho que aqui se apresenta e com base em nossa experiência docente no âmbito do italiano LE. 


\section{MATERIAIS AUTÊNTICOS: FONTES DE INPUT PARA A APRENDIZAGEM SIGNIFICATIVA DE UMA LÍNGUA ESTRANGEIRA}

Neste capítulo, nosso objetivo consiste em enfatizar a importância da utilização de materiais autênticos nas aulas de língua estrangeira (LE), particularmente, nas aulas de italiano LE. Pretendemos mostrar que esses materiais, se adequadamente didatizados, podem ser uma fonte de input compreensível para os alunos e, ao mesmo tempo, favorecer a aprendizagem significativa da língua-alvo por parte deles.

\subsection{Textos didáticos e textos autênticos: algumas definições}

No final da década de 1970 e durante a década de 1980, a abordagem comunicativa favoreceu, no âmbito da pedagogia de línguas, uma atenta análise dos contextos de uso linguístico e estimulou um grande debate referente ao conceito de autenticidade. Esse debate foi ocasionado não apenas em decorrência da importância que se passou a dar aos contextos de uso da língua, como também em virtude do combate à artificialidade dos textos veiculados por vários livros didáticos. Criou-se, assim, segundo Franzoni (1992), uma dicotomia que perdura, até hoje, na área de ensino-aprendizagem de línguas estrangeiras (LE): "autêntico"/“natural” versus "não autêntico"/“artificial”.

Nessa dicotomia, o primeiro polo, que se refere aos materiais autênticos, é, geralmente, considerado positivo, de acordo com a autora; e o segundo polo, que diz respeito aos textos didáticos, negativo. Contudo, ela ressalta não ter a intenção de reforçar tal dicotomia, e sim, de fazer uma reflexão a respeito da presença desses dois polos no ensino de LE.

Assim como essa estudiosa, não pretendemos reforçar essa dicotomia, mas apenas apresentar uma reflexão teórica e prática que temos desenvolvido, nos últimos anos, com relação à utilização de textos autênticos no processo de ensino-aprendizagem do italiano LE. Além disso, com base nas teorias que estudamos para fazer este trabalho e em nossa prática didático-pedagógica, podemos dizer que tanto os materiais autênticos quanto os didáticos têm sua utilidade no processo de ensino-aprendizagem de uma língua-alvo e podem "conviver", nesse processo, de maneira muito profícua para o professor e para os alunos. Nesta parte de nossa dissertação, discorreremos sobre as definições dadas aos termos texto didático e texto autêntico. 
Na pedagogia de línguas, em geral, os textos didáticos definem-se, basicamente, como sendo aqueles "elaborados por autor de material didático com objetivos puramente metacognitivos" (SILVA, 1999, p. 39). Ao usar a expressão "autor de material didático", Silva parece referir-se ao autor de livros didáticos; no entanto, como sabemos, nós, professores de línguas estrangeiras, também preparamos materiais específicos para nossos alunos, portanto, essa expressão também poderia fazer referência ao próprio docente. Bonvino (2008) reforça essa ideia, quando afirma que também podem ser considerados didáticos os materiais elaborados pelo professor de LE.

Os materiais didáticos são, portanto, os materiais preparados com a finalidade específica de se ensinar uma língua-alvo, independentemente de quem os tenha produzido (o autor de livros didáticos, ou o professor de LE). O representante principal dessa categoria de material é - afirma Franzoni - o livro didático (LD), também conhecido como livro de texto ou manual didático.

O LD é um caso particular de material didático, pois consiste em um suporte que contém, em geral, muitos gêneros textuais. O suporte, segundo Marcuschi (2008), é uma superfície física ou virtual que fixa e mostra o texto. Os gêneros contidos no LD são, em sua maioria, os da esfera do discurso pedagógico, como a explicação textual, as instruções para produção de textos, os exercícios escolares etc. Todavia, os livros didáticos de LE publicados nos últimos anos também contêm textos autênticos que se materializam em diversos gêneros, entre os quais: a receita culinária, o cardápio, o bilhete de trem, o poema, a entrevista, entre outros. Assim, podemos dizer que o LD é um material didático cuja constituição pode abranger tanto textos didáticos quanto textos autênticos, o que o caracteriza como um material especial.

De qualquer modo, no tocante à definição do termo texto didático, parece haver, portanto, certo consenso entre os estudiosos da área da pedagogia de línguas. As polêmicas referentes a essa categoria de material, e, especialmente ao LD, dizem respeito à sua utilização e serão abordadas mais adiante.

A definição do termo material autêntico, entretanto, não é consensual. De acordo com Franzoni (1992), o termo material ou documento autêntico foi empregado pela primeira vez, no âmbito da pedagogia de línguas, por Coste, que, em 1970, definiu-o da seguinte forma: "tudo aquilo que não foi preparado para o ensino de francês como língua estrangeira (...), aquilo que não é adaptado ou retocado (...) que não se limita somente a 
formas escritas" 5 (p. 36). Esse autor, contudo, não se mostrava muito satisfeito com a definição que ele mesmo propusera, pois definia material autêntico pela negação. Apesar disso, o termo continua a ser utilizado até hoje, no âmbito do ensino de línguas, para nomear os materiais que não são produzidos com finalidades didáticas.

Para Wilkins (1976), autor de Notional Syllabuses (obra que é considerada o marco da abordagem comunicativa), os materiais autênticos são aqueles que não foram escritos ou gravados para o discente estrangeiro, mas que foram originalmente elaborados para um público de falantes nativos.

Por sua vez, Widdowson $\left(1978\right.$, p. 113) ${ }^{6}$ afirma que texto autêntico seria "uma porção de discurso genuíno, uma amostra real de uso”. Para ele, a autenticidade se configura na relação dialógica entre o autor e o destinatário do texto. Assim, com base nos postulados desse teórico, podemos dizer que o aprendiz de uma LE, ao ter contato com um texto autêntico e compreendê-lo, reinterpreta e avalia os novos conteúdos, colocando-os no mundo ideológico e cultural que ele já possui. Desse modo, não se trata de adquirir um conhecimento novo, mas sim, de ampliar os próprios conhecimentos anteriores, o que determina um processo de apropriação, que se agiliza quanto maior for a qualidade e a quantidade dos conhecimentos prévios do estudante.

Já Breen (1985) considera que os materiais autênticos consistem em quaisquer fontes de dados que possam servir como meio de ajuda ao aprendiz para desenvolver uma interpretação autêntica, isto é, a interpretação mais próxima possível da que poderiam fazer os falantes nativos de uma língua. Para esse teórico, o texto autêntico é um mero instrumento dentro do processo de ensino-aprendizagem de uma LE. Esse autor afirma que a autenticidade é o resultado da interdependência entre textos, aprendizes, tarefas de aprendizagem e situação social da sala de aula.

Assim, a questão da autenticidade intrínseca aos textos ficaria, de acordo com tal estudioso, em um segundo plano, no qual passariam a ser considerados autênticos tanto os materiais produzidos com fins "comunicativos" ("autênticos" no sentido em que Coste e Wilkins empregam o termo) quanto aqueles que são elaborados ad hoc, com fins "metacomunicativos". Com base nos postulados de Breen, o foco da autenticidade

\footnotetext{
${ }^{5}$ Todas as traduções contidas nesta dissertação são de nossa autoria. No texto original, a frase de Coste, acima mencionada, é a seguinte: “(...) tout ce qui n'a pas été préparé à fins d'enseignement du français langue étrangère (...) ce qui n'est pas adapté ou retouché (...) pas seulement limité aux formes écrites".

${ }^{6} \mathrm{O}$ texto de Widdowson em cuja leitura nos baseamos para fazer esta dissertação é de 1978, mas, no presente trabalho, utilizamos a tradução desse texto feita, em 2005, por Almeida Filho.
} 
abrange tanto os materiais quanto as tarefas que são realizadas em um espaço social específico: a sala de aula, espaço em que, segundo o autor, tudo o que acontece é autêntico.

Quanto à questão da autenticidade dos textos, Nunan (1992), considera-a relativa; afirma que, nas aulas de LE, podem ser usados diálogos e textos escritos que visam exemplificar gramática e vocabulário, mas, também, textos que ele denomina naturalísticos e que, a seu ver, seriam aqueles reescritos a partir de textos autênticos, destinados a estudantes que se encontram em níveis principiantes.

Pallotti (1998) também relativiza o conceito de material autêntico, ressaltando que, se considerarmos que um texto seja autêntico para a comunidade para a qual foi criado, e, se os aprendizes estrangeiros forem tidos como uma comunidade, então até mesmo o texto criado ou simplificado com fins didáticos pode ser considerado autêntico.

Há estudiosos que questionam se o fato de se trabalhar o material autêntico, nas aulas de LE, torna-o menos autêntico. Para Johns (1994), por exemplo, um texto só pode ser considerado autêntico em seu contexto originário, ou seja, se empregado fora do contexto em que foi produzido, deixaria de ser um texto autêntico. $\mathrm{O}$ autor argumenta que, quando o texto passa a ser "instrumento de aprendizagem", perde sua autenticidade. Dessa maneira, a partir do momento em que tal texto é utilizado em sala de aula, deixa de ser rigorosamente autêntico e torna-se, praticamente, "didático", já que será usado no processo de ensino-aprendizagem da língua-alvo.

Brown e Menasche (s. d.), assim como Breen, consideram que a autenticidade está relacionada tanto aos materiais linguísticos quanto às tarefas propostas no processo de ensino-aprendizagem da LE. Para esses dois autores, há vários graus de autenticidade, e a autenticidade completa é impossível de se alcançar na sala de aula.

Quanto à autenticidade do input, definido como o texto escrito ou oral que é lido ou escutado pelo aprendiz, Brown e Menasche propõem cinco graus, que são os seguintes:

1. Autenticidade do input genuíno: o texto é criado apenas para a "vida real" (isto é, em um contexto real de comunicação entre falantes da LE), não para a sala de aula, mas é empregado no ensino da língua estrangeira.

2. Autenticidade do input alterado: não há mudança de significado no input original, porém, devido a modificações lexicais, gramaticais etc, esse insumo não é exatamente como o texto original. 
3. Autenticidade do input adaptado: o input é elaborado para a "vida real", no entanto é adaptado/simplificado pelo professor para ser usado na sala de aula.

4. Autenticidade do input simulado: o input é criado para a sala de aula, mas tenta copiar o estilo e o formato de um insumo genuíno; é o que Franzoni chamaria de material autentificado.

5. Inautenticidade: o input é criado para a sala de aula não com o intuito de assemelharse aos materiais autênticos propriamente ditos, embora possa apresentar algumas características em comum com eles.

No que se refere à autenticidade das tarefas, os graus propostos pelos dois teóricos são:

1. Autenticidade da tarefa genuína: existe quando os aprendizes participam de tarefas pelas mesmas razões e da mesma maneira que as realizariam no mundo real.

2. Autenticidade da tarefa simulada: nesse tipo de tarefa, há alguma tentativa de copiar o real na sala de aula, mas o foco está na aprendizagem da LE.

3. Autenticidade da tarefa pedagógica: ocorre quando não se tem a intenção de copiar o real, mas a tarefa é útil na sala de aula.

Segundo os dois estudiosos, esse modelo de graus de autenticidade do insumo e da tarefa é bastante adequado para abarcar a complexa realidade dos materiais, das atividades e da produção linguística dos alunos.

Tendo em vista os graus de autenticidade do input propostos por Brown e Menasche, parece-nos pertinente a ideia de que, sempre que possível, nós, professores de LE, devemos garantir a nossos alunos a oportunidade de trabalhar, em sala de aula, com materiais que apresentam insumo genuíno; ou seja, a nosso ver, é preferível trabalhar com textos autênticos sem modificações, adaptações ou simplificações, pois, fora da sala de aula, é com essa categoria de textos que os aprendizes se defrontarão. O que possibilitará a compreensão e a apropriação de tais textos pelos estudantes é o conjunto de atividades que o professor elaborará com base nesse material, e não alterações, adaptações ou simplificações operadas no texto.

Além do conceito de autenticidade, outro conceito importante, no âmbito da pedagogia de línguas, é o de autentificação. Segundo Franzoni (1992), tal conceito referese a um fenômeno que se vem dando em relação aos materiais didáticos: consiste em um fenômeno que opera, a princípio, no nível dos diálogos "simulados" que fazem parte dos manuais didáticos e que pode estender-se a toda a construção desses manuais. 
Os diálogos que compõem tais livros podem ser, basicamente, de dois tipos: os que propõem um texto autêntico (no sentido em que Coste e Wilkins empregam o termo), o qual se refere a uma comunicação natural, espontânea; e os que simulam um texto autêntico (texto oral simulado). A autentificação consistiria, assim, na transcrição de excertos de textos autênticos nos livros didáticos, ou na produção - pelos autores de tais livros - de textos cujo objetivo é o de assemelhar-se aos que são utilizados em situações reais de comunicação.

Com base nos aspectos já expostos, podemos dizer que há, no âmbito da pedagogia de línguas, basicamente, dois tipos de materiais: os didáticos e os autênticos; embora se possa considerar, também, a existência de uma categoria "intermediária" de material (os materiais autentificados). Quanto aos dois tipos básicos, os primeiros possuem uma definição unívoca, ou seja, não há controvérsias, entre os teóricos da área da pedagogia de línguas, quanto ao termo utilizado para nomear os materiais preparados especificamente para o ensino de uma língua-alvo. Os segundos, por sua vez, não apresentam uma única definição, isto é, o termo material autêntico possui significados diversos para diferentes autores.

Obviamente, nenhuma dessas definições pode ser considerada melhor do que as outras; trata-se apenas de definições diferentes entre si: algumas mais restritas, como as de Coste e Wilkins; outras mais amplas, como as de Widdowson e Breen, por exemplo. Considerando essa variedade de definições, bem como as especificidades da sala de aula de LE (espaço que tem a sua própria autenticidade, como afirma Breen; mas onde se realiza um processo um tanto quanto artificial, segundo Widdowson), parece-nos necessário apresentar a nossa definição para o termo material autêntico.

Para tanto, partiremos de uma questão levantada por Widdowson ${ }^{7}$, ao tratar da "artificialidade" do processo de ensino-aprendizagem de uma língua-alvo: "como podemos artificializar e, ainda assim, deixar a língua-alvo menos artificial?’. A nosso ver, tentar responder essa pergunta, poderia nos ajudar a formular nossa definição, que se baseia em algumas das que citamos anteriormente. Assim, para nós, o material autêntico é aquele que permite deixar a língua-alvo o menos artificial possível, devido ao fato de esse material não ter sido produzido com finalidades estritamente didáticas, mas com propósitos comunicativos reais.

\footnotetext{
${ }^{7}$ Ibid., p. 112.
} 
Portanto, de nosso ponto de vista, o termo material autêntico refere-se aos textos (orais, escritos, visuais ${ }^{8}$ ) que os falantes de uma determinada língua utilizam para se expressar e se comunicar uns com os outros; consistem em materiais que veiculam os aspectos sócio-histórico-culturais de uma comunidade linguística e que podem ser um instrumento valioso no processo de ensino-aprendizagem de uma língua estrangeira, constituindo-se numa fonte de insumo para os aprendizes. No presente trabalho, para referirmo-nos ao termo em questão, utilizaremos, doravante, a definição que acabamos de mencionar.

\subsection{Algumas polêmicas quanto à utilização de textos didáticos nas aulas de LE}

Como dissemos anteriormente, quanto à definição do termo texto didático, não há polêmicas entre os teóricos da área de glotodidática; há, todavia, polêmicas quanto à utilização desse tipo de material no processo de ensino-aprendizagem de línguas estrangeiras: há pesquisadores e professores que defendem o seu uso (em alguns casos, o seu uso exclusivo), mas há, também, alguns que preferem não empregar textos didáticos e que, como Widdowson (1978), apresentam argumentos não muito favoráveis à utilização desse tipo de material, tais como:

- a artificialidade dos textos didáticos, que, muitas vezes, assumem "um caráter de vitrine de amostras", o que reduz proporcionalmente a força do material linguístico como discurso. Afirma esse teórico que

(...) mesmo quando há uma tentativa de se introduzirem traços para emprestar uma aparência de normalidade, esses traços não se plasmam num texto de modo natural e servem somente para acentuar a sua anormalidade. Às vezes, por exemplo, os textos de leitura são apresentados em forma de diálogos, mas esses são tão obviamente um expediente cômodo para ressaltar a forma que acabam perdendo qualquer semelhança com prosa real ${ }^{9}$.

\footnotetext{
${ }^{8}$ Em nossa dissertação, baseando-nos em Comodi (1995) e em Begotti (s. d.), optamos por chamar de visuais os materiais autênticos em que são usadas unicamente imagens, como as fotografias e as pinturas. Neste trabalho, não nos ocuparemos desse tipo de material autêntico, visto que, no âmbito do ensino de LE, embora ele possa ser utilizado, por exemplo, para a realização de atividades de produção textual (oral e escrita), ele não é constituído por elementos linguísticos. Aqui, daremos ênfase ao trabalho com gêneros textuais que apresentam aspectos linguísticos (podendo, em alguns casos, também, apresentar elementos extralinguísticos, como as imagens). Marcuschi (2008) ressalta que há gêneros textuais cujas características não nos permitem classificá-los simplesmente como orais ou escritos, pois esses gêneros, além de abarcarem textos orais ou escritos, são acompanhados por imagens ou outros elementos extralinguísticos. Entre tais gêneros, podemos mencionar: a publicidade na TV, a história em quadrinhos, a charge, etc. Por isso, parece-nos razoável considerar que os materiais autênticos que se valem apenas de imagens sejam materiais visuais.

${ }^{9}$ WIDDOWSON, op. cit, p. 110.
} 
- o fato de esses textos, em geral, não estarem ligados a um contexto real de comunicação e de não apresentarem, portanto, uma dimensão de uso verdadeiro;

- a presença, nesse tipo de material, de grande quantidade de exercícios em que se utilizam frases isoladas e descontextualizadas.

Contudo, Widdowson esclarece que, ao apresentar esses argumentos, ele não tem a intenção de insinuar

(...) que textos desse tipo estejam inapelavelmente condenados: eles podem, sem dúvida alguma, servir a um propósito útil. Mas, é importante compreender, segundo meu melhor juízo, e o mais claramente possível, que tipo de linguagem eles apresentam exatamente e, com isso, poder apreciar os limites de sua utilidade $^{10}$.

De qualquer forma, segundo esse autor, tais materiais "são deficientes enquanto discurso, no sentido de que lhes falta a dimensão de uso verdadeiro" (p. 111). Concordando com esse teórico, podemos dizer que os materiais didáticos, mesmo quando bem estruturados, não refletem plenamente a complexa realidade da língua estrangeira e não atendem, em geral, os diferentes interesses do aprendiz.

Entretanto, é necessário lembrar que tal estudioso mostrava-se desfavorável à utilização de textos didáticos, porque, na época em que ele escreveu a obra que citamos nesta dissertação, esses textos empregados no ensino de LE (tanto os produzidos pelos autores de LD, quanto os que eram preparados pela maior parte dos professores de LE) não representavam nenhum gênero textual e eram demasiadamente diferentes dos produzidos em situações reais de comunicação; a respeito desses textos didáticos, Widdowson ressalta que eles

visam ser uma manifestação de partes selecionadas do sistema linguístico e, como consequência, acabam exibindo ocorrência tipicamente alta de certas estruturas. Esses textos assumem um caráter de vitrine de amostras e a sua força enquanto discurso diminui proporcionalmente (1978, p. 110).

Hoje em dia, porém, muitos dos livros didáticos publicados recentemente são bem elaborados; portanto, parecem satisfazer às necessidades dos alunos no que se refere à aprendizagem de uma língua-alvo. Um dos motivos pelos quais esses livros podem ser considerados bons é a presença de excertos de textos autênticos e de textos autentificados.

Apesar de os novos livros didáticos contribuírem para que os discentes possam se comunicar em situações reais, é fundamental que o professor, em suas aulas, não se limite ao uso desse instrumento de ensino-aprendizagem, visto que, como afirma Franzoni, o

${ }^{10}$ Ibid., p. 111. 
livro didático constitui apenas uma forma - a dos autores - de apresentar a LE como objeto de estudo e, portanto, não deve ser visto nem pelo docente nem pelos aprendizes como depositário da língua a ser estudada. Ademais, os próprios autores de livros didáticos fazem ressalvas quanto ao uso exclusivo desse tipo de material. Mezzadri (2003, p. 96), por exemplo, ressalta que o LD "tende a uniformizar os estudantes, a homologá$\operatorname{los}^{11}$,

Entretanto, obviamente, por ser um teórico da área da pedagogia de línguas, mas, também, um renomado autor de manuais didáticos para o ensino do italiano LE, esse estudioso apresenta os seguintes argumentos favoráveis ao emprego do material em questão:

O livro de texto oferece a possibilidade didática de seguir um percurso planejado, organizado e efetivado em uma proposta balanceada e integrada que leva em conta múltiplos aspectos ligados ao projeto educativo em sua totalidade. Para o estudante, o livro de texto constitui um guia, uma referência organizada, frequentemente dotada de materiais de consulta, como glossários, esquemas resumidores etc que permitem uma visão global e uma possibilidade de gestão autônoma em fase de estudo ${ }^{12}$.

Com relação, especificamente, aos livros didáticos de italiano para estrangeiros, Spinelli (2003, p. 134) salienta que "não é desejável pensar que (...) os livros de texto, mesmo nos casos em que são bem estruturados e articulados, reflitam plenamente a complexa realidade do italiano e encontrem os heterogêneos interesses dos estudantes ${ }^{13}$ ".

Desse modo, é possível afirmar que o manual didático não é capaz de atender aos diversos interesses dos alunos e tende a deixar de lado a heterogeneidade que caracteriza qualquer grupo de estudantes; em outras palavras, não existe um LD que sirva para todos, que atenda aos diferentes interesses de todos os aprendizes. Aliás, todos nós, professores, sabemos bem que não existe material (didático ou autêntico) com essa característica, e é por isso que é importante que, na sala de aula de língua estrangeira, não seja utilizado exclusivamente um único tipo de material.

\footnotetext{
${ }^{11}$ No original: “(...) tende a uniformare gli studenti, a omologarli”.

${ }^{12}$ No original: "Il libro di testo offre la possibilità didattica di seguire un percorso pianificato, organizzato e realizzato in una proposta bilanciata e integrata che tiene presente molteplici aspetti legati al progetto educativo nel suo insieme. Per lo studente il libro di testo costituisce una guida, un riferimento organizzato, spesso fornito di materiali di consultazione, quali glossari, schemi riassuntivi ecc che permettono uno sguardo d'insieme e una possibilità di gestione autonoma in fase di studio" (MEZZADRI, 2003, p. 95).

${ }^{13}$ No original: "Non è auspicabile pensare che (...) i libri di testo, anche nei casi in cui risultino ben strutturati ed articolati, riflettano appieno la complessa realtà dell'italiano e incontrino gli eterogenei interessi degli studenti".
} 


\subsection{A importância da utilização de materiais autênticos no ensino de línguas estrangeiras}

De acordo com Begotti (s. d.), Comodi (1995) e Spinelli (2003), os textos autênticos são valiosos materiais que podem ser utilizados nas aulas de italiano LE, pois apresentam a língua em uso, a língua em situações reais de comunicação. $\mathrm{O}$ uso dos materiais autênticos, manifestações vivas da cultura e da civilização que se comunica por meio da língua na qual foram produzidos - a língua italiana, em nosso contexto de trabalho docente -, revela-se fundamental no sentido de levar o estudante de italiano LE a uma descoberta agradável da língua e da cultura italianas e em direção a um melhor conhecimento de si mesmo, de sua própria língua e de sua própria cultura.

Segundo Comodi (1995), os textos autênticos constituem modelos reais de língua, ou seja, apresentam a língua em contextos reais de comunicação, uma vez que não são produzidos com fins didáticos. Ademais, os materiais autênticos trazem, em si, marcas do contexto sócio-histórico-cultural no qual foram elaborados, ilustrando diversos modelos de língua oral e escrita.

Margutti (2004) afirma que os estrangeiros que aprendem italiano na Itália têm um contato privilegiado com o idioma, uma vez que estão em um ambiente de imersão, no qual se deparam com a L2 pelas ruas, nos restaurantes, nas escolas, nas lojas e em todos os lugares por onde passam, o que lhes possibilita, também, um contato privilegiado com a cultura do país. Para tais aprendizes, portanto, falar, escrever, compreender o que escutam e o que leem em italiano constitui uma necessidade.

Já para os estudantes de italiano no Brasil não existe, em geral, um contato privilegiado com a língua e a cultura italianas. Às vezes, a aula de italiano representa uma das poucas possibilidades que os discentes têm para praticar a produção oral e escrita em italiano, bem como a compreensão oral e escrita nesse idioma. Por isso, a aula de italiano LE precisa ser prazerosa para os estudantes. Com o intuito de tornar mais interessantes as aulas, o professor pode valer-se dos materiais autênticos.

Hoje em dia, como todos sabemos, os alunos, mesmo sem estar na Itália, podem ter contato com a língua italiana fora da sala de aula; esse contato pode ocorrer, por exemplo, através da internet. Mas, geralmente, nesta, eles não encontrarão textos didáticos, e sim, diferentes textos autênticos. Por isso, na sala de aula, se não trabalharmos materiais autênticos junto aos estudantes, estes terão, provavelmente, dificuldades para compreender tais textos e/ou para produzir textos em situações reais de 
comunicação que se desenvolvem fora das aulas, como as dos bate-papos, no MSN ou no Skype, com parentes e amigos italianos.

Tendo em vista esse aspecto, utilizar, nas aulas, materiais autênticos significa, segundo Comodi (1995), não apenas dar aos alunos condições para enfrentar a realidade fora da sala de aula, como também ajudá-los a desenvolver as habilidades que lhes serão úteis na vida real, e o modo mais eficaz de se exercitar uma habilidade parece ser o de praticá-la durante as aulas.

A utilização dos materiais autênticos, no ensino, parece, dessa maneira, ser ainda mais profícua, vantajosa e necessária em realidades como a brasileira, isto é, numa realidade de um país distante da Itália, em que alguns alunos têm remotas possibilidades de uma estada no país em que se fala a língua estrangeira por eles estudada e, para os quais, "as trocas com os nativos são muito reduzidas, e são os materiais didáticos que constituem grande parte do input ${ }^{14 "}$ (Bonvino, 2008, p.10).

Todo texto autêntico produzido em italiano representa uma manifestação original da cultura italiana em um dado momento, em relação a um determinado contexto e, desse modo, oferece aos alunos um modelo de entendimento das situações e de comportamento por parte dos italianos. De acordo com Comodi (1995), o uso dos materiais autênticos pode despertar, nos discentes, certa curiosidade quanto às diferenças entre sua própria cultura (no caso, a brasileira) e a cultura italiana, certa complacência no reconhecimento de comportamentos semelhantes, uma grande satisfação em saber fazer um paralelo entre a cultura brasileira e a italiana.

Ainda segundo a autora, esse estabelecimento de diferenças e semelhanças facilita o processo de aproximação dos alunos brasileiros à cultura italiana e pode promover, neles, uma espécie de afetividade. Conhecer a língua, a história e os costumes da Itália por meio dos textos autênticos pode levar os estudantes a aprender a respeitar e a apreciar a cultura italiana, pelas diferenças e semelhanças que esta tem com a cultura brasileira.

Além disso, quanto à escolha dos materiais a serem utilizados na sala de aula, Bonvino (2008, p. 26-27) sustenta que

há muitas razões para preferirmos materiais autênticos. Usá-los na classe significa (...) favorecer a motivação dos estudantes à aprendizagem, tratando modelos de língua diretamente ligados à realidade sociocultural contemporânea em contínua evolução ${ }^{15}$.

\footnotetext{
${ }^{14}$ No original: “(...) gli scambi con i nativi sono molto ridotti e sono i materiali didattici che costituiscono gran parte dell'input”.

${ }^{15}$ No original: "Vi sono molte ragioni per preferire materiali autentici. Usare in classe materiali autentici significa (...) favorire la motivazione degli studenti all'apprendimento, trattando modelli legati alla realtà socioculturale contemporanea in continua evoluzione".
} 
Margutti (2004, p. 49) argumenta que os textos autênticos podem ser usados como recursos para variar e enriquecer as oportunidades de exposição dos estudantes aos usos da língua em situações reais de comunicação. Contudo, a autora esclarece que

\begin{abstract}
não se quer, aqui, sugerir que se usem somente materiais autênticos na classe, mas se trata de ter consciência das características e potencialidades que estes podem ter em um percurso de ensino da língua e, portanto, de balancear e integrar a proposta didática com instrumentos adequados aos diversos objetivos do ensino no decorrer da aula, ou de um percurso inteiro de ensino, e às necessidades dos estudantes ${ }^{16}$ (grifo da autora).
\end{abstract}

$\mathrm{O}$ argumento que essa autora apresenta vai ao encontro do que já dissemos anteriormente: nas aulas de língua estrangeira, é importante e necessário empregar diferentes materiais, pois, no processo de ensino-aprendizagem da LE, os materiais autênticos e didáticos podem, sim, conviver de maneira muito proveitosa tanto para o docente quanto para o discente.

Contudo, sempre que possível, é fundamental que usemos textos autênticos em nossas aulas, porque estes dão aos alunos a oportunidade de ter acesso ao que Brown e Menasche denominam input genuíno, o qual, segundo Spinelli, contribuirá para o desenvolvimento da estrutura cognitiva do aprendiz, para o desenvolvimento de suas habilidades intuitivas e analíticas e, também, para a aproximação deles à cultura do povo falante nativo da língua-alvo.

Tendo em vista a importância do insumo genuíno no processo de ensinoaprendizagem da LE, trataremos, nesta dissertação, da didatização de materiais que veiculam apenas esse tipo de input, isto é, textos que, embora sejam utilizados na sala de aula, foram produzidos em um contexto real de comunicação entre falantes da línguaalvo. Mas, o que significa didatizar um material autêntico?

$\mathrm{Na}$ literatura consultada, não encontramos uma definição para o termo didatizar, embora muitos autores o empreguem; entre eles, podemos citar: Balboni (1994), Mezzadri (2003), Spinelli (2003), Bonvino (2008) e Begotti (s.d.). Esses teóricos utilizam frequentemente o termo em questão e seus correlatos ("didattizzazione", "didattizzato", "didatticizzazione" etc), todavia não dizem, de forma elucidativa, o que eles significam.

Por isso, foi-nos necessário, com base na leitura das obras de tais autores, elaborar uma definição, que é a seguinte: didatizar um texto autêntico significa, basicamente,

\footnotetext{
${ }^{16}$ No original: "Non si vuole qui suggerire di usare solo materiali autentici in classe, ma si tratta di essere consapevoli delle caratteristiche e potenzialità che questi possono avere in un percorso di insegnamento della lingua e, quindi, nel bilanciare e integrare la proposta didattica con strumenti adeguati ai diversi obiettivi dell'insegnamento nel corso della lezione o di un intero percorso di insegnamento e ai bisogni degli studenti".
} 
torná-lo acessível e compreensível aos discentes, não a partir de simplificações, adaptações ou alterações promovidas nesse texto, mas sim, a partir de atividades elaboradas com base nele e que possam ir ao encontro das necessidades e dos interesses dos alunos, permitindo-lhes, portanto, compreender o texto autêntico trabalhado em sala de aula e apropriar-se dele.

A didatização é, de acordo com Begotti, um processo árduo e complexo, para o desenvolvimento do qual não basta criar alguns exercícios de forma improvisada; é um processo que requer tempo, estudo e dedicação por parte do professor que se propõe a realizá-lo.

A didatização de materiais autênticos representa uma mudança muito importante no âmbito metodológico, uma mudança que, segundo Kumaravadivelu (2006), faz parte da Era Pós-Método: nesta, o professor não é mais visto como passivo (que simplesmente segue livros didáticos e programas propostos, quase sempre, por outras pessoas - diretor, coordenador etc), mas sim, como um criador ativo de atividades.

Nessa perspectiva, o professor tem a autonomia de saber como agir dentro dos limites acadêmicos e administrativos impostos pelas instituições, pelos currículos e pelos livros didáticos, desenvolvendo uma abordagem crítico-reflexiva sobre a sua própria prática de ensino; dessa abordagem, faz parte a didatização de materiais autênticos que o docente considere úteis no processo de ensino-aprendizagem da língua-alvo.

No capítulo 3, discorreremos mais detidamente sobre o conceito de didatização e suas implicações no âmbito da pedagogia de línguas; agora, no entanto, trataremos do conceito de input, que é primordial em nossa dissertação.

\subsection{A definição de input}

O termo input refere-se à língua-alvo oferecida ao aprendiz e, segundo Balboni (1999), foi empregado, pela primeira vez, na área de didática das línguas estrangeiras, por Krashen, um estudioso que pode ser considerado cognitivista, pois seus postulados baseiam-se, segundo Borneto (1998, p. 30):

(...) no estudo dos conhecimentos linguísticos adquiridos (e, por assim dizer, 'introjetados') por crianças e adultos após vários tipos de exposição à língua materna e às línguas estrangeiras. Nesse sentido, refere-se ao desenvolvimento 
das capacidades cognitivas (relativamente à língua) que uma pessoa experimenta, em geral, nas várias fases de sua vida ${ }^{17}$.

Em 1977, Krashen propôs sua Teoria de Aquisição de Segunda Língua ${ }^{18}$. Essa teoria sofreu modificações sucessivas por parte de seu autor, que, em 1985, apresentou sua versão definitiva, declarando-se absolutamente convencido de sua validade.

A teoria em questão é composta por cinco hipóteses: distinção entre aquisição e aprendizagem, ordem natural, monitor, insumo compreensível e filtro afetivo. Segue, abaixo, uma breve descrição de cada uma delas.

A primeira hipótese, a da distinção entre aquisição e aprendizagem diz respeito aos processos envolvidos na apropriação de uma segunda língua. Krashen (1982) explica que os adultos apresentam dois modos diferentes e independentes de desenvolver competência numa língua-alvo.

O primeiro consiste na aquisição, que é um processo muito parecido com a forma como as crianças desenvolvem a capacidade que possuem em sua primeira língua (L1) ${ }^{19}$. Esse processo é subconsciente, isto é, quando ocorre a aquisição da L2, o adquirente ${ }^{20}$ nem sempre se dá conta de que está se apropriando dela; só percebe isso, ao ver-se utilizando a língua-alvo para comunicação. Para Krashen, podem ser considerados sinônimos de aquisição os termos aprendizagem implícita, aprendizagem informal e aprendizagem natural.

O segundo modo de desenvolver competência em uma língua estrangeira, por sua vez, é o processo de aprendizagem, que, segundo o autor da Teoria de Aquisição de Segunda Língua, consiste no conhecimento consciente de uma língua-alvo, em saber regras, ter consciência delas e saber dizê-las. Para esse estudioso, alguns sinônimos de aprendizagem da LE podem ser conhecimento formal e aprendizagem explícita.

\footnotetext{
${ }^{17}$ No original: “(...) sullo studio delle conoscenze linguistiche acquisite (e per così dire 'introiettate') da bambini e adulti a seguito di vari tipi di esposizione alla lingua materna e alle lingue straniere. In questo senso si riferisce allo sviluppo delle capacità cognitive (relativamente alla lingua) che una persona sperimenta in generale nelle varie fasi della propria vita".

${ }^{18}$ Krashen desenvolveu a Second Language Acquisition Theory para tentar explicar, inicialmente, processos referentes à apropriação do inglês como L2. Todavia, posteriormente, esse autor propôs a aplicação de sua teoria aos processos que envolvem a apropriação da LE. Por isso, na parte 1.4 de nossa dissertação (parte em que trataremos, especificamente, dessa teoria), os termos segunda língua e língua estrangeira serão empregados indistintamente.

${ }^{19} \mathrm{O}$ termo primeira língua (L1) refere-se à língua adquirida na infância - por esse motivo, considerada primeira ou nativa - e, em geral, no convívio familiar - em especial, no convívio com a mãe -, por isso, denominada, também, materna (cf. BALBONI, 1999 e PALLOTTI, 1998). Assim, em nosso trabalho, empregaremos os termos primeira língua (L1) e língua materna (LM) como sinônimos.

${ }^{20}$ Utilizaremos os termos adquirente e aprendiz como sinônimos, pois, em nosso trabalho, a distinção entre aquisição e aprendizagem, proposta por Krashen, não é de grande relevância. Portanto, nesta dissertação, empregaremos os termos aquisição e aprendizagem, bem como seus correlatos, do mesmo modo que o fazem Pallotti (1998), De Marco e Wetter (2000) e Bonvino (2008), autores que os usam, geralmente, como sinônimos.
} 
De acordo com Krashen, os adultos também têm a capacidade de adquirir língua, o que não significa que eles serão sempre capazes de atingir níveis de falantes nativos na língua-alvo. $\mathrm{O}$ autor sustenta que o adulto pode acessar o mesmo dispositivo de aquisição de língua usado pela criança, isto é, sob sua ótica, os processos de aquisição da primeira língua e da segunda língua são similares. Além disso, para ele, a aquisição e a aprendizagem são dois processos distintos e independentes, o que implica dizer, por exemplo, que a aprendizagem não pode se tornar aquisição.

A segunda hipótese, a da ordem natural, propõe que a aquisição de estruturas gramaticais processa-se numa ordem previsível, ou seja, os adquirentes de uma determinada língua têm a tendência de internalizar certas estruturas gramaticais mais cedo, e outras, mais tarde. Os percursos de aquisição de diferentes indivíduos não são sempre exatamente os mesmos, porém há, entre essas trajetórias, semelhanças claras e estatisticamente significativas. Ademais, Krashen ressalta que, embora a ordem de aquisição de uma segunda língua não seja a mesma que a da primeira língua, existem semelhanças entre ambas as ordens de aquisição.

Já a terceira hipótese, a do monitor, tem a ver com o desempenho em segunda língua. Segundo tal hipótese, a aquisição e a aprendizagem são utilizadas de maneiras bastante específicas. A primeira é responsável pela nossa produção e pela nossa fluência em uma L2; já a segunda funciona como um monitor ou editor, sendo responsável unicamente por promover mudanças na forma dos enunciados que produzimos. Tais mudanças podem ocorrer antes de falarmos ou escrevermos, ou depois, na autocorreção.

De acordo com a hipótese do monitor, as regras formais, ou aprendizagem consciente, apresentam um papel bastante limitado no desempenho em segunda língua. $\mathrm{O}$ desempenho, afirma Widdowson (1978), baseando-se em Chomsky, tem dois aspectos: o da forma gramatical (conhecimento de regras linguísticas) e o do uso comunicativo (conhecimento de regras linguísticas para a comunicação eficaz). Assim, o monitor estaria muito mais relacionado ao primeiro aspecto do que ao segundo.

Segundo Krashen, para que o monitor possa funcionar adequadamente, precisam ser satisfeitas três condições; estas são necessárias, porém não são suficientes, ou seja, o aprendiz pode não utilizar sua gramática consciente, ainda que as três condições sejam satisfeitas. As condições a que se refere Krashen são as seguintes:

- tempo: para poder pensar a respeito das regras e usá-las com eficácia, o adquirente de uma L2 precisa de tempo suficiente; 
- foco na forma: para utilizar o monitor de modo eficiente, o aprendiz da L2 precisa estar atento à forma (gramatical);

- conhecimento das regras: é preciso que o aprendiz conheça as regras linguísticas.

Desse modo, as situações monitoradas são aquelas em que se focaliza a forma, e não a comunicação. Em situações não monitoradas (foco no uso comunicativo), segue-se a ordem natural; já em situações monitoradas, não se segue a ordem natural; seguem-se ordens de dificuldade. O monitor possibilita, ao usuário de uma L2, utilizar formas linguísticas que ele já aprendeu, mas que ainda não adquiriu.

Quanto à variação individual no uso do monitor, Krashen diz que há três tipos básicos de desempenhador linguístico:

- superusuários do monitor: pessoas que tentam monitorar o tempo todo, comparando a sua produção ao conhecimento consciente que possuem da L2. Esses usuários são tão preocupados com a correção, que não conseguem expressar-se com fluência;

- subusuários do monitor: são os que confiam plenamente no sistema adquirido e não usam (ou não têm) conhecimento consciente das regras gramaticais. Quando se autocorrigem, geralmente o fazem por ter uma intuição do que é correto;

- usuários ótimos do monitor: são aqueles que usam o monitor, sem deixá-lo interferir na comunicação. Tais usuários podem valer-se de sua competência aprendida para suplementar sua competência adquirida.

A quarta hipótese, a do input compreensível, é a que interessa particularmente à nossa pesquisa. Essa hipótese busca responder a questão que, segundo Krashen, é uma das mais importantes da área da pedagogia de línguas: como adquirimos linguagem? De acordo com tal hipótese, uma condição necessária para avançar de um estágio $i$ (que indica a competência corrente, o estágio atual em que se encontra o aprendiz) para o estágio $i+1$ é a de que o adquirente compreenda o input que contenha $i+1$, em que compreender quer dizer que o aprendiz presta atenção ao sentido, e não à forma da mensagem.

Krashen, com essa hipótese, defende a ideia de que adquirimos linguagem apenas quando compreendemos a que contém estruturas "um pouco além" do estágio em que estamos naquele momento. Ele explica esse aparente paradoxo, afirmando que, para compreender textos na língua-alvo, usamos não apenas a nossa competência linguística, como também o contexto, nosso conhecimento de mundo e informações extralinguísticas.

Para o autor da Teoria de Aquisição de Segunda Língua, a hipótese do insumo está relacionada à aquisição, e não à aprendizagem. Além disso, ele acredita que, quando o 
input é compreendido e em quantidade suficiente, $i+1$ terá sido automaticamente apresentado. Ainda dentro dessa hipótese, Krashen defende a ideia de que a capacidade de produção oral emerge, com o tempo, por si própria, bastando, para que isso ocorra, fornecer insumo compreensível ao aprendiz.

A hipótese do insumo compreensível - afirma esse teórico - está relacionada a outros pressupostos envolvidos no processo de aquisição de segunda língua. Um deles é o "período silencioso", um fenômeno que se observa melhor na aquisição de L2 por crianças. Este diz respeito ao período em que, durante meses no processo de aquisição de L2 em ambiente linguístico natural e informal, a criança (ou o adquirente adulto) fala pouco. Isso se deve ao fato de a criança estar construindo uma competência na segunda língua ao seu redor, competência que se desenvolve por meio, exclusivamente, do ouvir e compreender, segundo Krashen.

A quinta hipótese, a do filtro afetivo, estabelece como os fatores afetivos relacionam-se ao processo de aquisição de L2. Serve para explicar por que aprendizes expostos à mesma quantidade de input compreensível têm tempos e êxitos de aprendizagem diferentes. $\mathrm{O}$ conceito de filtro afetivo foi, segundo Krashen, proposto por Dulay e Burt. O autor da Teoria de Aquisição de Segunda Língua postula a existência de três categorias de variáveis afetivas que interferem no processo de aquisição de uma língua-alvo, a saber: a motivação (alunos mais motivados tendem a obter melhores êxitos nesse processo), a autoconfiança (aprendizes confiantes e com uma imagem positiva de si mesmos, em geral, obtêm melhores resultados na aquisição de uma L2) e ansiedade (a baixa ansiedade favorece o processo em questão).

O filtro afetivo é uma barreira psicológica que age para impedir que o input seja utilizado na aquisição da língua-alvo. Isso quer dizer que alunos com filtro afetivo baixo tendem a ter um melhor desempenho no processo de apropriação da L2. Krashen sustenta que o insumo compreensível e o grau de rigidez do filtro são as verdadeiras causas da aquisição de uma L2.

A teoria de Krashen foi alvo de severas críticas (cf. MCLAUGHLIN, 1987), por ser considerada muito vaga e generalizante. O próprio Krashen admite que é difícil, por exemplo, definir, de modo prático, a noção de input +1 . O mesmo problema acontece a outros conceitos de sua teoria: quais critérios empíricos podem ser usados para estabelecer que um determinado aprendiz utilizou o monitor? Como saber se certa regra foi aprendida, e não adquirida? Como se pode averiguar se o filtro afetivo está alto ou baixo? Como se pode definir quem e quando o usa? Assim, segundo Pallotti (1998), o 
problema principal das hipóteses propostas por Krashen é que elas não consistem em afirmações científicas.

Apesar disso, a teoria de Krashen é útil, pois fornece um quadro geral do processo de aquisição de uma segunda língua, e, dentro de tal quadro, é possível levantar questões mais específicas, que podem ser verificadas empiricamente. O conceito elaborado pelo autor da Teoria de Aquisição de Segunda Língua que interessa à nossa pesquisa é o de input compreensível, pois, a nosso ver, didatizar textos autênticos significa torná-los compreensíveis aos alunos, proporcionando-lhes um contato agradável com a LE, o que poderá resultar na aprendizagem significativa (ou até mesmo na aquisição, de acordo com a distinção proposta por Krashen) da língua estrangeira.

No tocante ao conceito de insumo compreensível, a principal crítica feita a Krashen deve-se ao fato de ele afirmar que o input compreensível seja o principal fator responsável pela aquisição de uma língua. Não concordamos com esse teórico, quando faz tal afirmação; porém, assim como Pallotti (1998) e Bonvino (2008), defendemos, sim, a ideia de que, embora o input compreensível não seja suficiente, ele é necessário e indispensável no processo de ensino-aprendizagem de uma LE. Nesse sentido, a didatização de materiais autênticos pode ser uma das formas de fazer o input tornar-se compreensível para os alunos. Portanto, esse conceito da teoria de Krashen é muito pertinente à nossa pesquisa.

Apesar de fazer certas críticas à teoria de Krashen (as quais se apoiam nas críticas já feitas por McLaughlin), Pallotti (1998), baseando-se nos conceitos propostos pelo autor da Teoria de Aquisição de Segunda Língua, retoma dois processos importantes relacionados ao input: o intake e o output. O primeiro consiste na parte do insumo à qual o adquirente presta atenção e que mantém, pelo menos por um período breve, em sua memória. O segundo, por sua vez, refere-se a tudo aquilo que o aprendiz produz, tanto oralmente quanto por escrito. Esse teórico italiano salienta que o processo de aprendizagem linguística resulta de uma interação dinâmica entre input e processos cognitivos do aprendiz e afirma que o insumo, para se tornar intake, tem de ser, ao menos em parte, compreensível.

Assim, ele define input compreensível como sendo os discursos que conseguimos entender, mesmo que não sejamos capazes de produzi-los e mesmo que não compreendamos todos os detalhes desses discursos.

Elisabetta Bonvino (2008) concorda com Pallotti, quando esse teórico ressalta a importância de o input ser, pelo menos parcialmente, compreensível; a autora explica que, 
para ela, isso significa que o insumo deve ser acessível ao nível do estudante, mas sem ser muito fácil, ou seja, é importante que o insumo possa ser compreendido pelo aluno e lhe forneça novos conhecimentos.

Para delinear brevemente os mecanismos cognitivos responsáveis pelo processo de aquisição, essa estudiosa apoia-se num modelo teórico do processo de aquisição linguística (modelo adotado, por exemplo, por Ellis e por Pallotti), que é considerado uma expansão e uma superação do modelo proposto por Krashen. Esse modelo envolve os conceitos de input, intake, output (os quais, originalmente, fazem parte da Teoria de Aquisição de Segunda Língua, de Krashen) e interlíngua. Tais postulados podem ser explicados da seguinte maneira: nem todo o input recebido é captado pelo aluno, pois, às vezes, ele ainda não tem condições de captá-lo. A parte do insumo que o aprendiz capta passa a constituir o intake, ou seja, a parte do input reelaborada pelo aprendiz, a qual compõe e reestrutura o seu sistema interlinguístico (ou interlíngua).

A interlíngua consiste no sistema linguístico do aprendiz, constituído pelas suas tentativas de chegar à $\mathrm{L} 2 \mathrm{e}$, portanto, um sistema em contínuo progresso. $\mathrm{O}$ intake é a parte do input que o aprendiz realmente adquire. A partir do intake, é possível produzir novas frases na língua-alvo; a essa produção dá-se o nome de output. Para que o input se torne intake, é preciso que o input seja notado e compreendido pelo aluno.

A esse respeito, Pallotti nos chama a atenção para o fato de que a transformação do input em intake depende, em última análise, do aprendiz: é somente este que pode fazer com que o material linguístico que o circunda seja notado, elaborado, analisado e integrado ao seu sistema interlinguístico. Assim, Pallotti defende a ideia de que a pura e simples quantidade de insumo (mesmo que grande) não é capaz de produzir todos esses efeitos, se não houver um empenho ativo por parte de quem aprende. Quanto a essa ideia, concordamos totalmente com esse teórico, pois a responsabilidade pela aprendizagem de uma língua-alvo não pode ser atribuída apenas ao professor, ao input, às atividades realizadas nas aulas etc, mas também (e, talvez, sobretudo) ao estudante, que deve ter um papel ativo em seu próprio processo de aprendizagem da LE.

De qualquer forma, o insumo é, como já foi dito, um dos fatores que favorecem esse processo, portanto, é possível concluir que

(...) existem, no momento, algumas provas da utilidade do input compreensível para o processo de aquisição e, sobretudo, não existe qualquer prova do fato de 
que um input menos compreensível produza resultados melhores ${ }^{21}$ (PALLOTTI, 1998, p. 163).

Desse modo, com base em tudo o que foi exposto nesta parte de nosso trabalho, podemos dizer que o insumo é um dos fatores necessários e indispensáveis no processo de aprendizagem da LE; por essa razão, precisamos ter clareza do que é e de como se dá tal processo, assunto acerca do qual discorreremos a seguir.

\subsection{Aquisição e aprendizagem: processos complementares}

A distinção entre aquisição e aprendizagem constitui, como vimos, a primeira hipótese da teoria de Krashen (1982), autor para quem ambos os processos são formas distintas e "separáveis" de se desenvolver competência em uma segunda língua; isto é, para o autor da Teoria de Aquisição de Segunda Língua, aquisição e aprendizagem são processos distintos e independentes um do outro e, portanto, a aprendizagem não conduz à aquisição.

Entretanto, como já mencionado, Krashen sofreu duras críticas por causa do caráter vago e generalizante de sua teoria. De fato, no que concerne à sua primeira hipótese, é muito difícil saber, com precisão, os limites entre esses dois processos, como salienta Pallotti. Vejamos, abaixo, o que postulam alguns autores a respeito dessas duas formas de se apropriar de uma língua-alvo.

Danesi (1998) explica que, geralmente, em neurolinguística, o termo aquisição refere-se ao processo de apropriação da L1, ou, também, de uma L2 em casos de bilinguismo precoce. O termo aprendizagem, por sua vez, diz respeito à língua estrangeira que, sob tal perspectiva, é considerada uma segunda língua estudada em contexto escolar, formal. Contudo, considerando a plasticidade cerebral, é possível dizer que a aquisição e a aprendizagem não configuram processos separáveis.

Do ponto de vista neurolinguístico, o processo de aquisição envolve, principalmente, as modalidades metafóricas do hemisfério direito; já a aprendizagem de uma LE, em contextos formais, envolve, sobretudo, as modalidades analíticas do hemisfério esquerdo.

\footnotetext{
${ }^{21}$ No original: “(...) esistono al momento alcune prove dell'utilità dell'input comprensibile per il processo di acquisizione e, soprattutto, non esiste alcuna prova del fatto che un input meno comprensibile produca risultati migliori".
} 
Os hemisférios direito e esquerdo correspondem a duas estratégias comunicativas diversas, tanto durante a aquisição da língua materna por crianças quanto durante a aprendizagem da língua estrangeira por adultos. Por isso, tanto o processo de aquisição quanto o de aprendizagem podem ser vistos como o resultado das estratégias adotadas para efetuar a comunicação. Elas seriam típicas tanto das interações íntimas e informais quanto das interações formais. Um falante adulto pode adotar ambos os tipos de estratégias, de acordo com o interlocutor e com o contexto da situação comunicativa, mas, também, com base em fatores socioculturais assumidos durante o seu processo de aproximação da cultura veiculada pela língua-alvo.

Ainda segundo Danesi, em situações íntimas e informais, estão envolvidas, sobretudo, as funções neuropsicológicas do hemisfério direito do cérebro, as quais são características do processo de aquisição da língua. Em situações mais formais, por sua vez, têm maior desempenho as funções do hemisfério esquerdo, as quais estão relacionadas ao processo de aprendizagem linguística.

$\mathrm{Na}$ idade adulta, nas primeiras fases do processo de aprendizagem da LE, o hemisfério direito oferece maior contribuição do que em fases mais avançadas. Nestas, o hemisfério esquerdo domina o processo. Isso quer dizer que, como o cérebro é um órgão que tem muita plasticidade e pode ser modificado pela experiência, a aprendizagem de uma língua-alvo pode mudar, sensivelmente, a organização cerebral.

Assim, sob a ótica neurolinguística, aquisição e aprendizagem são termos que designam processos diferentes, mas que complementam um ao outro na organização cerebral de um indivíduo que está se apropriando de uma língua-alvo.

Sob a perspectiva glotodidática, de acordo com alguns teóricos, entre os quais Pallotti (1998), a primeira hipótese da teoria de Krashen também é questionável. O autor do livro La seconda lingua usa os termos aquisição espontânea (ou natural, ou não dirigida) para designar a aquisição de uma segunda língua em um contexto natural, em que não há um ensino explícito da língua, mas todos a usam nas interações; e aquisição dirigida (ou mediante instrução) para referir-se à aquisição de uma língua estrangeira em um contex to de instrução explícita, por exemplo, através de aulas.

Assim, Pallotti denomina aquisição espontânea ao processo que Krashen chama simplesmente de aquisição, e ao processo que este teórico chama de aprendizagem aquele dá o nome de aquisição dirigida. Além disso, Pallotti, no livro já citado, afirma empregar os termos aquisição e aprendizagem, quase sempre, como sinônimos, fazendo distinção entre ambos apenas quando extremamente relevante. 
Portanto, para esse autor, aquisição e aprendizagem são, geralmente, sinônimos, pois, a seu ver, ambos os processos são complementares, o que torna difícil delimitá-los. Ademais, ele sustenta que a dicotomia aquisição/aprendizagem não dá conta de explicar os diversos processos envolvidos na aquisição de uma língua.

De Marco e Wetter (2000) ampliam a primeira hipótese da teoria de Krashen e, também, discordam dele, no tocante à dicotomia aquisição/aprendizagem. Tais autoras mencionam a existência de três tipos de processos de apropriação de uma língua-alvo: a aprendizagem espontânea, a aprendizagem dirigida e a aprendizagem mista. Essas estudiosas ressaltam que entre os três tipos não há limites nítidos. Da mesma forma que Pallotti, elas utilizam os termos aquisição e aprendizagem como sinônimos: ora utilizam os três termos que acabamos de mencionar, ora utilizam, como equivalentes destes, respectivamente, os termos aquisição espontânea, aquisição dirigida e aquisição mista.

No que concerne ao primeiro tipo de aprendizagem de uma segunda língua, elas afirmam que a aquisição espontânea ocorre quando a L2 é aprendida em um contexto resultante de situações comunicativas autênticas. Nestas, o input é fornecido em velocidade normal e por numerosos falantes; além disso, ele não se apresenta sempre de modo nítido e claro e não é formulado em função do desenvolvimento linguístico do aprendiz. As autoras destacam, também, a importância da cultura no processo de aprendizagem espontânea, afirmando que o insumo, nesse tipo de aquisição, implica uma dimensão pragmática que envolve uma nova dimensão cultural. Assim, o aprendiz encontra-se diante de um mundo cultural diferente, razão pela qual a sua situação vai além da aprendizagem linguística.

Quanto ao segundo tipo, elas esclarecem que a aquisição se dá, em geral, em um lugar determinado (a sala de aula) e com um tempo definido (horas de curso). Nesse caso, o input oferecido prevê uma progressão linear, e a língua a ser aprendida é ensinada por uma ou por poucas pessoas.

No tocante ao terceiro tipo, as duas teóricas explicam que a aprendizagem mista envolve tanto a aquisição espontânea quanto a dirigida. Nesse caso, o insumo não só abrange as dimensões pragmáticas, como também facilita o desenvolvimento das habilidades que, na aprendizagem espontânea, são deixados de lado, como a leitura e a escrita. Enquanto a aprendizagem dirigida leva, sobretudo inicialmente, a uma aplicação linguística orientada por regras, e a aprendizagem espontânea, a uma aplicação de comunicação espontânea, muitas vezes incorreta do ponto de vista gramatical, a aprendizagem mista promove uma competência comunicativa melhor, segundo as autoras. 
Por fim, com o intuito de melhor explicar esse terceiro tipo de aquisição de uma língua-alvo, elas salientam que os processos de aprendizagem de um idioma não são puramente espontâneos ou dirigidos: mesmo em situações de aprendizagem espontânea, é possível haver momentos de aprendizagem dirigida e vice-versa.

No trabalho que aqui se apresenta, assim como Pallotti, De Marco e Wetter, empregaremos os termos aquisição e aprendizagem como sinônimos, pois concordamos com esses teóricos, quando afirmam que é difícil estabelecer os limites entre ambos os processos. Parece-nos, portanto, mais adequado dizer que a aquisição e a aprendizagem não são processos que se contrapõem, mas sim, processos que se complementam; não configuram uma oposição, mas sim, uma sequência, um continuum, constituindo, desse modo, processos indissociáveis.

\subsection{A aprendizagem significativa}

"O que o aluno já sabe deve servir de andaime para que ele alcance o que ainda não sabe".

Vilson Leffa

Considerando a aquisição e a aprendizagem de uma LE como processos complementares e indissociáveis, gostaríamos de destacar, na presente dissertação, a importância da Teoria da Aprendizagem Significativa, de David Ausubel (1968). Por ser um psicólogo da educação, sua teoria refere-se ao ensino-aprendizagem em geral, e não especificamente ao ensino-aprendizagem de LE. Contudo, parece-nos que os postulados desse teórico podem ser aplicáveis ao âmbito da pedagogia de línguas, porque, geralmente, nas aulas de LE, um de nossos principais objetivos consiste em propiciar aos alunos a aprendizagem significativa da língua-alvo.

Ausubel é um representante do Cognitivismo, corrente da psicologia que se originou no final da década de 1960, em contraposição à Psicologia Behaviorista. Portanto, esse autor propõe uma explicação teórica do processo de aprendizagem segundo um ponto de vista cognitivista, apesar de reconhecer a importância da experiência afetiva em tal processo. Os objetos de estudo da Psicologia Cognitiva são os processos de compreensão, transformação, armazenamento e utilização da informação envolvida na cognição. 
Esta consiste no processo por meio do qual o mundo de significados tem origem: à medida que o ser humano se situa no mundo, estabelece relações de significação, isto é, atribui significados à realidade em que se encontra. Tais significados não são entidades estáticas, mas pontos de partida para a atribuição de outros significados. Origina-se, então, a estrutura cognitiva (os primeiros significados), a qual se configura como pontos básicos de ancoragem dos quais derivam outros significados.

Nesse sentido, Ausubel define a aprendizagem significativa como um processo no qual o novo conhecimento é adquirido, atribuído e construído através da interação com algum conhecimento prévio, especificamente relevante, existente na estrutura cognitiva do aprendiz. Segundo o autor, esta consiste em uma edificação mental ordenada, isto é, uma estrutura mental em que o aprendiz armazena todos os conhecimentos. A partir dessa interação, ambos os conhecimentos se modificam: o novo passa a ter significados para o aprendiz, que amplia sua estrutura cognitiva, e o prévio adquire novos significados, tornando-se mais elaborado, mais refinado.

A aprendizagem significativa, que, segundo Moreira (2001), é o conceito mais importante da teoria de Ausubel, processa-se quando novas ideias, informações ou conceitos interagem com os que são relevantes, abrangentes e já disponíveis na estrutura cognitiva do aprendiz. Essas ideias, informações e conceitos novos são assimilados pelos já existentes, contribuindo para sua diferenciação, elaboração e estabilidade. Aquilo que já existe na estrutura cognitiva funciona, então, como ancoradouro para o novo conhecimento.

Desse modo, para Ausubel, a aprendizagem significativa diz respeito a um processo de aquisição de conhecimentos, no qual um conhecimento já existente na estrutura cognitiva do aprendiz serve como ancoradouro, isto é, como ponto de apoio para o novo conhecimento. O conhecimento prévio que servirá de ancoradouro para o novo conhecimento e que, ao mesmo tempo, em virtude da ancoragem, se transformará, é denominado subsunçor (subsumer). Ausubel esclarece, então, que o aprendiz deve ter os subsunçores adequados para dar significado ao novo conhecimento.

A expressão subsunçores adequados diz respeito aos conhecimentos prévios relacionados ao conceito ou conteúdo a ser aprendido. Isso quer dizer que o conhecimento a ser adquirido não interage com qualquer conhecimento prévio, mas sim, com um subsunçor que tenha alguma relação com o novo conhecimento.

O autor da Teoria da Aprendizagem Significativa defende a ideia de que o fator que mais influencia a aprendizagem é aquilo que o estudante já sabe, ou seja, seus 
conhecimentos prévios. Ausubel admite, contudo, que eles não são o único fator que exerce influência sobre tal processo. Se considerarmos, especificamente, o âmbito do ensino-aprendizagem de LE, podemos afirmar que há, basicamente, três tipos de conhecimentos prévios:

- o conhecimento linguístico - o aluno já possui conhecimentos referentes, no mínimo, à sua própria L1 e, em muitos casos, a outras línguas estrangeiras;

- o conhecimento de mundo;

- o (re)conhecimento das diferentes características e estratégias linguísticas, comunicativas e estilísticas que fazem parte dos variados gêneros textuais orais e escritos.

Esses três tipos poderão influenciar o processo de aprendizagem significativa da língua-alvo pelo estudante e, portanto, nós, professores de LE, devemos levá-los em consideração, no momento de preparar nossas aulas e de selecionar e/ou elaborar os materiais a serem usados nestas, visando torná-los realmente instrumentos de ensinoaprendizagem da língua estrangeira. A esse respeito, Leffa (s. d.), um teórico brasileiro cujos postulados vão ao encontro da teoria de Ausubel, ressalta que

para que a aprendizagem ocorra, é também necessário que o material entregue
ao aluno esteja adequado ao nível de conhecimento do conteúdo a ser
desenvolvido. O que o aluno já sabe deve servir de andaime para que ele
alcance o que ainda não sabe. Ninguém aprende algo que é totalmente
conhecido e nem algo que seja totalmente novo. A capacidade de acionar o
conhecimento prévio do aluno é uma condição necessária para o sucesso de um
determinado material (p. 16, grifo nosso).

A relevância dos conhecimentos prévios do aprendiz, no processo de aprendizagem de uma língua estrangeira, também é, de certa forma, destacada por Krashen: na hipótese do insumo compreensível, esse teórico salienta que, para compreender textos na língua-alvo, usamos não apenas a nossa competência linguística, como também o contexto, nosso conhecimento de mundo e informações extralinguísticas. Krashen diz, na verdade, que, para compreender um texto oral ou escrito, na LE, utilizamos os conhecimentos prévios de que dispomos. Nesse sentido, a hipótese do input compreensível corrobora os postulados da teoria ausubeliana.

Ausubel considera altamente organizado o armazenamento de conhecimentos na mente humana; nessa organização, forma-se uma hierarquia conceitual, na qual conhecimentos mais específicos são relacionados a conceitos e proposições mais gerais, mais amplos. No tocante ao âmbito específico do ensino-aprendizagem de línguas, sob a ótica cognitivista, a linguagem é considerada parte integrante e integrada do sistema 
cognitivo geral da mente humana, ancorada à percepção, às capacidades associativas e à organização geral da mente. Nessa perspectiva, a linguagem tem um papel fundamental na aquisição de conhecimentos, pois é através dela que o ser humano estabelece relações com o mundo que o circunda, adquirindo e assimilando novos conhecimentos.

As crianças adquirem conhecimentos, sobretudo, por meio de um processo denominado formação de conceitos, o qual está relacionado à construção de conhecimentos por meio de descobertas, elaborações e avaliações de hipóteses e de generalizações; esse processo dá origem aos primeiros subsunçores.

Os adultos, por sua vez, possuem, normalmente, um grande número de subsunçores, por isso, raramente adquirem conhecimentos através da formação de conceitos; nessa fase da vida, em geral, a formação de conceitos é substituída pela assimilação de conceitos, que é o resultado da interação entre conhecimentos prévios e novos.

Assim, o mecanismo humano de aprendizagem, na fase adulta, é, por excelência, a assimilação; ou seja, o indivíduo, em particular o adulto, tende a usar conhecimentos prévios (subsunçores) para assimilar novos conhecimentos, isto é, para atribuir-lhes significados, que passarão a integrar sua estrutura cognitiva.

Em sua teoria, Ausubel discorre, também, sobre a aprendizagem mecânica, ou seja, aquela em que novos conhecimentos são incorporados à estrutura cognitiva sem encontrar um conhecimento no qual se ancorar, como se fossem informações a serem memorizadas ao "pé da letra". É esse tipo de aprendizagem que ocorre, por exemplo, em geral, quando solicitamos aos estudantes que memorizem regras gramaticais ou listas de palavras. Quando o armazenamento, a internalização e a incorporação de conhecimentos se dão de forma arbitrária e sem atribuição de significados, diz-se que a aprendizagem é mecânica ou automática.

Uma grande questão levantada pelos postulados de Ausubel diz respeito à origem dos conhecimentos prévios: caso eles não estejam presentes na estrutura cognitiva para viabilizar a aprendizagem significativa, como é possível criá-los? Como resposta a essa questão, Ausubel apresenta a definição de aprendizagem mecânica, afirmando que esta se faz necessária e inevitável, no momento em que o aprendiz se defronta com informações ou conceitos que lhe sejam inteiramente novos.

Afirma, ademais, que, posteriormente, a aprendizagem mecânica pode transformar-se em significativa. Portanto, esses dois tipos de aprendizagem não configuram uma dicotomia, uma oposição; há, na verdade, um continuum entre ambas. 
Pensando na aplicação da teoria de Ausubel à área de didática das línguas estrangeiras, é possível dizer que os alunos adultos utilizarão, como subsunçores, seus conhecimentos linguísticos da e na L1 (e/ou de outras línguas que eles conheçam), seu conhecimento de mundo e o (re)conhecimento das diferentes características e estratégias linguísticas, comunicativas e estilísticas que fazem parte dos variados gêneros textuais orais e escritos. Nessa perspectiva, Ausubel salienta que o ensino de uma LE deveria ter como ponto de partida os conceitos que o aluno já possui em sua LM. Para reforçar essa ideia de Ausubel, citamos, a seguir, um trecho do livro de Widdowson (1978, p. 21-22):

(...) por exemplo, o professor, nos estágios iniciais de um curso de língua estrangeira, poderia levantar uma caneta, apontar para ela e dizer: Isto é uma caneta. (...) É verdade que a frase faz referência a algo na situação criada pelo professor. Mas essa situação que ele criou não é aquela que normalmente exigiria dele fazer uso de tal frase. Os alunos sabem que o objeto é uma caneta. O que eles não sabem é como esse objeto é denominado na nova língua (grifo nosso).

Como sabemos, em sua obra, nas páginas acima mencionadas, Widdowson discorre sobre as diferenças entre forma gramatical e uso comunicativo da língua. Mas, a nosso ver, o trecho que acabamos de citar também pode ser usado para ilustrar a importância de o professor levar em consideração os conhecimentos prévios que os alunos já têm em sua língua materna e/ou em outras línguas.

Por isso, com base nos postulados de Ausubel e de Widdowson, podemos dizer, a partir do exemplo citado por este, que o aprendiz já formou o conceito de caneta em sua primeira língua, ou seja, o estudante já tem, em sua mente, esse conhecimento; o que o aluno ainda não sabe é como nomear esse objeto na língua-alvo. Assim, o professor, para favorecer a aprendizagem significativa da língua estrangeira, sobretudo nos estágios iniciais de estudo da LE pelos discentes, deve levar em conta os conhecimentos prévios destes e ter uma postura tolerante com relação à presença da L1 dos aprendizes na sala de aula.

Para que ocorra a aprendizagem significativa, além de ter os subsunçores adequados, também é essencial que o aluno queira dar significado aos novos conhecimentos, ou seja, é preciso que ele se predisponha a aprender significativamente, esforçando-se em integrar os novos conhecimentos às aquisições cognitivas anteriores. Em geral, o que é aprendido de maneira significativa tem, muitas vezes, significados pessoais. Isso quer dizer que o aluno aprende mais e melhor aquilo que desperta o seu interesse. No tocante a esse aspecto, Bonvino (2008, p. 19), fazendo referência especificamente ao ensino de L2, afirma que 
do ponto de vista dos conteúdos, de fato, os interesses dos indivíduos podem ser extremamente variados e dependem, em grande parte, da rede de conhecimentos que o indivíduo construiu até aquele momento. Se um elemento não tem nada a ver com os conhecimentos prévios de um indivíduo, é mais fácil que não desperte o seu interesse. Se, ao contrário, um elemento, mesmo sendo novo, encontra algum ponto de apoio na rede de conhecimentos de um indivíduo, será mais facilmente considerado saliente por ele ${ }^{22}$ (grifo nosso).

Por um lado, isso quer dizer que, geralmente, aquilo que desperta o nosso interesse está relacionado ao repertório cognitivo de que já dispomos; e que, por outro lado, algo acerca do qual não temos absolutamente nenhum conhecimento dificilmente despertará o nosso interesse.

Assim, baseando-nos nos postulados de Ausubel e de Bonvino, podemos afirmar que os conhecimentos prévios têm realmente importância central no processo de ensinoaprendizagem de uma língua-alvo: estes são responsáveis, em grande parte, pelo processo de aprendizagem significativa e, também, pelos interesses do aprendiz.

De acordo com a teoria ausubeliana, a aprendizagem significativa é facilitada quando os elementos mais gerais, mais abrangentes de um conteúdo são introduzidos em primeiro lugar e, posteriormente, então, esse conteúdo é progressivamente diferenciado, em termos de detalhe e especificidade. Assim, segundo Ausubel, ao prepararmos nossas aulas, devemos ter em mente que os aspectos mais gerais e mais abrangentes da disciplina a ser ministrada devem ser apresentados no início para, somente depois, serem progressivamente detalhados. Ao propor isso, tal estudioso baseia-se em duas hipóteses:

- é mais fácil o aprendiz captar aspectos pormenorizados de um conteúdo abrangente previamente aprendido do que chegar a esse conteúdo por meio de suas partes; ou seja, é mais fácil partir do todo para se chegar aos detalhes que o compõem do que partir destes pare se chegar àquele;

- a organização dos conhecimentos referentes a uma determinada disciplina, na mente de um indivíduo, consiste em uma estrutura hierárquica, em cujo topo estão as ideias mais abrangentes, mais amplas; estas, progressivamente, incorporam proposições, conceitos e fatos menos abrangentes e mais detalhados.

Transpondo esse princípio para o âmbito glotodidático, é possível afirmar que, no ensino de línguas, é preferível ter o texto como unidade de ensino-aprendizagem, em vez de frases ou palavras isoladas. Esse princípio implica, também, no fato de que é

\footnotetext{
${ }^{22}$ No original: "Dal punto di vista dei contenuti, infatti, gli interessi degli individui possono essere estremamente vari e dipendono in gran parte dalla rete di conoscenze che l'individuo si è costruito fino a quel momento. Se un elemento non ha nulla a che vedere con le conoscenze pregresse di un individuo, è più facile che non susciti il suo interesse. Se invece un elemento, pur essendo nuovo, trova qualche appiglio alla rete di conoscenze di un individuo, sarà da questi più facilmente considerato saliente".
} 
importante partir do texto para se chegar às partes que o compõem, e não o contrário. No ensino de LE, tal princípio é aplicado, por exemplo, quando utilizamos, em nossas aulas, primeiramente, as técnicas de compreensão global e, depois, as de compreensão detalhada: partimos do texto como um todo para se chegar aos seus detalhes, o que poderá favorecer a aprendizagem significativa da língua-alvo.

Moreira (2001, p. 72), embora defenda e divulgue a teoria de Ausubel no Brasil, parece interpretar sua aplicação ao âmbito da pedagogia de línguas de maneira equivocada, ao dizer que "frase e som são os conceitos mais inclusivos relevantes ao ensino de língua estrangeira". Essa afirmação é equivocada, se levarmos em conta que, como postula a Linguística Textual, as pessoas não se comunicam através de frases e sons isolados, mas sim, por meio de textos. O texto é, portanto, o conceito mais abrangente, na área de didática das línguas estrangeiras sob uma perspectiva ausubeliana e, por esse motivo, deveria ser o ponto de partida, o material de base para o processo de ensinoaprendizagem de uma LE.

Moreira defende a ideia de que, nos estágios iniciais de estudo de uma LE, sejam ensinadas frases na língua estrangeira e fonemas dessa língua, através de comparações com a língua materna dos estudantes. Não concordamos com essa ideia, porque, a nosso ver, a LM serve, sim, como subsunçor para a aprendizagem significativa da LE, portanto o uso daquela não deve ser proibido na sala de aula de LE; mas, se a L1 for utilizada nas aulas de modo descontextualizado, como no caso proposto pelo autor em questão (isto é, partindo-se de frases e fonemas isolados), é provável que os alunos não desenvolvam uma aprendizagem significativa da língua-alvo, e sim, uma aprendizagem mecânica.

Tendo em vista os aspectos já tratados, podemos afirmar que, se um de nossos objetivos, como professores de LE, consiste em favorecer o processo de aprendizagem significativa da língua-alvo, é imprescindível levarmos em conta os conhecimentos prévios de nossos alunos, pois é a partir disso que conheceremos os interesses e as necessidades de aprendizagem dos estudantes e, poderemos, então, preparar nossas aulas de modo a propiciar um ensino da língua estrangeira que realmente atenda tais interesses e necessidades. 


\title{
2. A PRESENÇA (OU AUSÊNCIA) DE MATERIAIS AUTÊNTICOS EM ALGUNS DOS PRINCIPAIS MÉTODOS E ABORDAGENS DE ENSINO DE LÍNGUAS ESTRANGEIRAS ${ }^{23}$
}

\author{
"Per comprendere un ambito di studi è sempre utile conoscerne, \\ almeno a grandi linee, la storia ${ }^{24 \%}$.
}

Gabriele Pallotti

O capítulo que aqui se apresenta tem como objetivo uma análise da presença (ou ausência) dos materiais autênticos em alguns dos principais métodos e abordagens de ensino de línguas estrangeiras, desde os métodos tradicionais até a abordagem comunicativa.

\subsection{Abordagem, método e técnica - algumas definições}

Para situar, no âmbito do ensino-aprendizagem de línguas estrangeiras, os materiais autênticos, objeto central de nosso estudo, faz-se necessária a compreensão de três conceitos fundamentais dessa área: os de abordagem, método e técnica. Quanto à definição desses termos, não há um consenso entre os diversos teóricos que se dedicaram ao seu estudo. Portanto, no presente trabalho, não faremos uma tentativa de delimitação terminológica; apenas apresentaremos algumas definições propostas por estudiosos que tentaram explicar as diferenças entre esses três termos.

Em 1963, Anthony ${ }^{25}$, citado por Richards e Rodgers (1986), propôs um esquema hierárquico para definir os conceitos já mencionados; para ele, a abordagem é o nível em que pressupostos e crenças sobre o que seja uma língua e sobre o que seja ensinar uma língua são especificados; a abordagem define-se, assim, como uma teoria, uma filosofia de ensino de línguas. Já o método consiste no nível em que a teoria é colocada em prática e em que as escolhas são feitas com base em habilidades específicas a serem ensinadas. $\mathrm{O}$ método seria, então, segundo esse teórico, o nível intermediário entre a abordagem e as

\footnotetext{
${ }^{23}$ Um resumo deste capítulo foi apresentado no V Encontro de Pós-Graduandos (V EPOG) da Faculdade de Filosofia, Letras e Ciências Humanas da Universidade de São Paulo, realizado em outubro de 2010. Alguns meses após o evento, o texto apresentado foi publicado, sob a forma de artigo, em um CD que reúne todos os textos apresentados no V EPOG.

${ }^{24}$ Tradução nossa: "Para compreender um âmbito de estudos, é sempre útil conhecer, pelo menos em linhas gerais, a sua história" (PALLOTTI, 1998, p.16).

${ }^{25}$ ANTHONY, E. M. “Approach, method and technique”. In: English Language Teaching 17: p. 63-67.
} 
técnicas. Estas, por sua vez, consistem no nível em que são descritos os procedimentos de sala de aula.

Richards e Rodgers, diferentemente de Anthony, consideram que, no topo dessa hierarquia, está o método, ao qual se subordinam a abordagem, o planejamento e a técnica, que se encontram no mesmo nível.

Para Borneto (1998), o método é algo que vai além de uma técnica ou de uma estratégia de ensino, pois faz referência a uma teoria de ensino, a uma teoria linguística, a uma série de hipóteses sobre o aprendiz e sobre a natureza da aprendizagem. Parece-nos que, ao fazer menção ao termo teoria de ensino, o autor está, na verdade, tratando do conceito de abordagem; isto é, para ele, assim como para Anthony, o método estaria subordinado à abordagem. Esse teórico italiano, em seu livro C'era una volta il metodo, explica o que significa, na prática, a seu ver, tal conceito e por que ele e tantos outros teóricos são "contra" o método:

$\mathrm{Na}$ prática, este [o método] implica um conjunto de atitudes implícitas ou explícitas que fazem dele uma espécie de sistema de referência para o professor, até tocar os problemas da escolha, articulação e progressão dos materiais didáticos a serem utilizados na interação com os alunos. E é exatamente esse caráter sistemático e que tende a ser rígido que foi colocado em discussão, mesmo porque cada método enfatiza apenas alguns aspectos da didática e da aprendizagem em detrimento dos outros. (...) Na realidade, não pode existir um método que seja bom para todas as situações que se apresentam na praxe do ensino, porque várias são as exigências e diferentes os atores que participam $\operatorname{dela}^{26}$.

Balboni (1995), por sua vez, também apresenta uma perspectiva teórica que vai ao encontro das concepções de Anthony e de Borneto, ou seja, para o docente da Università Ca' Foscari, a abordagem é a dimensão em que se explicitam tanto as finalidades da educação linguística quanto os objetivos do ensino da LE e em que se definem as coordenadas científicas com base nas quais propor métodos que possam atingir os objetivos do processo de ensino-aprendizagem de uma língua-alvo. Já o método seria, para esse estudioso, um conjunto de princípios metodológicos e didáticos que traduzem uma abordagem em modelos. A técnica, por sua vez, consistiria em uma atividade que representa as indicações do método e as finalidades da abordagem.

\footnotetext{
${ }^{26}$ No texto original: "In pratica, esso implica un insieme di assunzioni implicite o esplicite che ne fanno una sorta di sistema di riferimento per l'insegnante fino a toccare $i$ problemi della scelta, articolazione $e$ progressione dei materiali didattici da utilizzare nell'interazione con gli allievi. Ed è proprio questo carattere sistematico e tendenzialmente rigido che è stato messo in discussione, anche perché ciascum metodo enfatizza solo alcuni aspetti della didattica e dell'apprendimento a scapito degli altri. (...) In realtà non può esistere un metodo che vada bene per tutte le situazioni che si presentano nella prassi dell'insegnamento, perché varie sono le esigenze e differenti gli attori che vi prendono parte" (BORNETO, 1998, p. 18).
} 
Esse teórico salienta que não há métodos certos/errados, bons/ruins, mas apenas adequados ou não à abordagem que se propõem a colocar em prática. Ele também ressalta que as técnicas não são boas/ruins, modernas/antiquadas; são simplesmente coerentes ou não com o método e a abordagem, além de serem eficazes ou não no que se refere a atingir os objetivos didáticos previamente estabelecidos.

Almeida Filho (1993) propõe uma perspectiva teórica que também é baseada na de Anthony. De acordo com o teórico brasileiro, a abordagem também encontra-se no topo da hierarquia e consiste em uma força que imprime movimento ao processo de ensinar e aprender uma língua; é uma filosofia, um enfoque que envolve um conjunto de conhecimentos, pressupostos, crenças e teorias referentes ao que é uma língua e ao que é aprender e ensinar uma língua-alvo. O método, por sua vez, consistiria em um conjunto de princípios metodológico-didáticos que se traduzem no modo de organizar a experiência de ensinar e de aprender uma língua. Já as técnicas, entendidas como as atividades propriamente ditas, consistiriam, juntamente com os procedimentos e os recursos, o terceiro nível hierárquico na proposta de Almeida Filho.

Dentro do modelo proposto por esse autor, estão relacionados à abordagem de ensino:

- o planejamento das unidades de um curso;

- a produção e/ou seleção de materiais;

- o método;

- a avaliação do rendimento dos alunos (mas também a própria autoavaliação do professor).

Reproduzimos, a seguir, um esquema que ilustra o modelo proposto por esse teórico no livro Dimensões comunicativas no ensino de línguas. Como se vê em tal esquema, a abordagem influencia todas as fases da operação global do ensino de línguas. 


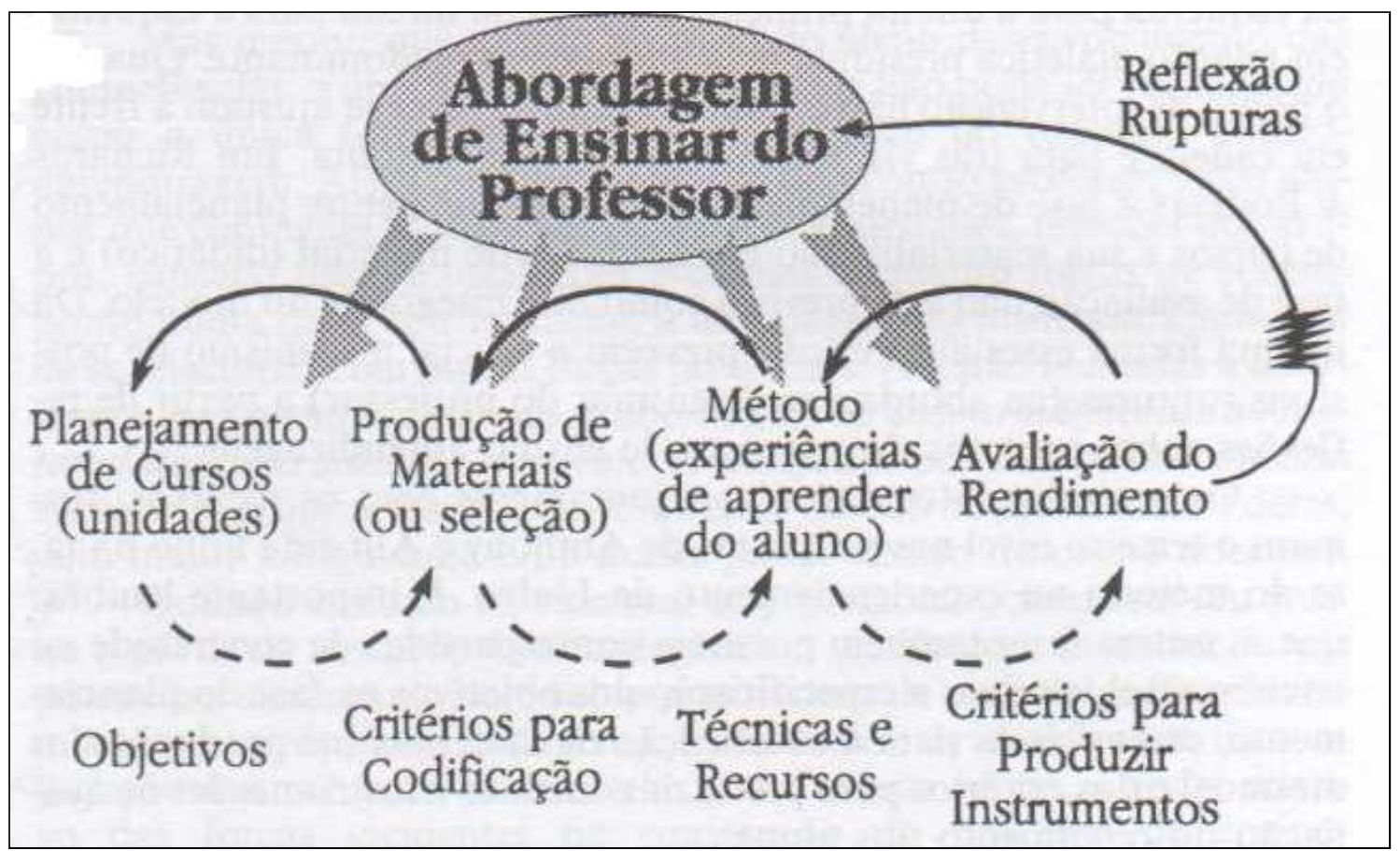

Figura 1 - Modelo da operação global do ensino de línguas proposto por Almeida Filho ${ }^{27}$

Baseando-nos em tal proposta, podemos afirmar que abordagem, método e técnica são conceitos distintos um do outro e que são partes de um esquema hierárquico que caracteriza a operação global do ensino de línguas. Com base nesse modelo, também podemos dizer que a escolha e a elaboração de materiais estão diretamente relacionadas à abordagem, ou seja, optar por um determinado material, em detrimento de outro, tem a ver, sobretudo, com a abordagem de ensinar do professor.

Como dissemos anteriormente, os materiais autênticos são o foco de nosso estudo, por isso, interessa-nos compreender em que medida esses materiais estão presentes ou não em diferentes métodos e abordagens de ensino de línguas. A seguir, trataremos desse assunto.

\subsection{A utilização (ou não) de textos autênticos nos métodos tradicionais de ensino de línguas estrangeiras}

Na história do ensino de línguas estrangeiras, encontram-se diversos métodos e abordagens; os métodos mais "antigos", empregados em âmbito glotodidático, são

\footnotetext{
${ }^{27}$ ALMEIDA FILHO, op. cit, p. 19.
} 
denominados métodos tradicionais. Dentre eles, os principais são: o método gramática e tradução, o método da leitura (reading method), o método direto e o método audiolingual.

Como já dissemos anteriormente, nosso objetivo consiste em verificar se os materiais autênticos estavam presentes (ou não) em tais métodos. Para tanto, discorreremos brevemente sobre cada um deles e tentaremos analisar em que medida os materiais que são nosso objeto de estudo eram utilizados (ou não) em cada um dos métodos tradicionais de ensino de LE.

\subsubsection{Método gramática e tradução}

O método gramática e tradução foi desenvolvido, inicialmente, para o ensino das línguas clássicas (o latim e o grego, línguas em cujo âmbito continua a ser empregado até os dias atuais) e difundiu-se a partir do final do século XVIII. Considerava-se importante estudar as línguas clássicas, porque elas representavam o meio de conhecer o pensamento antigo e a literatura greco-romana e, também, porque se pensava que essas línguas tivessem uma estrutura lógica muito rígida, cujo estudo poderia melhorar a capacidade de raciocínio dos aprendizes.

Na Europa, no século XIX, esse método também passou a ser utilizado no ensino das línguas modernas, embora se soubesse que elas apresentavam características diferentes das línguas clássicas: estas são conhecidas apenas sob a forma escrita, isto é, aquilo que sabemos a respeito delas nos foi legado em forma de textos escritos, especialmente, de textos literários; ademais, as línguas clássicas não são línguas faladas, o que também as difere das chamadas línguas modernas.

O estudo das línguas clássicas era considerado uma atividade de alta cultura e prestígio, enquanto o estudo das línguas modernas era tido como uma atividade menos prestigiosa; por isso, acreditava-se que empregar, no ensino destas, o mesmo método utilizado no ensino daquelas seria uma maneira de tornar as línguas modernas tão "nobres" quanto as clássicas.

Como podemos ver por seu nome, o método em questão dá muita importância a dois aspectos: a gramática e a tradução. Por meio da tradução, o aprendiz tem contato não apenas com a língua estrangeira, mas também com a sua literatura, que representava a forma mais significativa, mais elegante e mais prestigiosa de expressão linguística. 
Dentro desse método, a língua é vista como um conjunto de regras a serem aprendidas, uma a uma, utilizando-se como ponto de partida as tradicionais classes gramaticais, ou seja, artigo, substantivo, adjetivo, verbo, advérbio etc. Essas regras são apresentadas pelo professor ao aprendiz em sua língua materna (LM/L1), ou seja, o ensino da LE ocorre em L1. Tal método não possui bases teóricas, portanto, nesse sentido, é pré-teórico (PIVA, 2000, p. 179). Conhecer uma língua significa aprender as suas regras gramaticais e o léxico, através da tradução. A tradução de textos literários ou de frases elaboradas ad hoc é a atividade central (praticamente exclusiva) proposta por tal método.

As habilidades receptivas (compreensão oral e escrita) são trabalhadas a partir de frases isoladas e de excertos de textos literários: o aluno entra em contato, praticamente, apenas com a língua literária e tem pouquíssimo contato com a língua oral. Esta é trabalhada, basicamente, através de ditados, atividade em que o aprendiz escuta e transcreve palavras isoladas e frases soltas, fora de contexto, pronunciadas várias vezes pelo professor, que é o ponto de referência essencial, sendo considerado o "detentor do saber", aquele que conhece a LE. Os alunos, por sua vez, têm um papel muito passivo, quase exclusivamente receptivo. Ademais, os interesses e necessidades deles não são levados em conta, uma vez que o método não prevê intervenções dos estudantes durante as aulas.

Já as habilidades produtivas (produção oral e escrita) são desenvolvidas a partir do exercício de tradução; por isso, exercita-se pouco a produção oral. Consequentemente, os aprendizes não desenvolvem uma boa pronúncia na língua-alvo: a pronúncia é, em geral, descrita sob a forma de sons isolados e letras que se assemelham ou se diferenciam dos da língua materna.

Como as aulas são ministradas na L1 dos alunos, o método é destinado a classes monolíngues. Além disso, como requer a leitura e a tradução de textos literários, esse método era utilizado para ensinar uma LE a estudantes que tivessem um nível cultural médio-alto.

Os textos literários são os principais materiais utilizados no método gramática e tradução e consistem em um tipo de texto autêntico, embora, naquela época, ainda não fossem assim denominados (como vimos, o termo material autêntico surgiu na década de 1970).

A literatura é uma fonte de material autêntico, visto que os textos literários são produzidos sem finalidade didática e veiculam a cultura do povo que se expressa por meio 
da língua em que foram escritos. Assim, parece-nos possível dizer que o uso dos materiais autênticos na pedagogia de línguas nasceu junto com os métodos de ensino de LE: o primeiro método de ensino de línguas estrangeiras foi o método gramática e tradução e ele já propunha o emprego de um tipo de texto autêntico, antes mesmo que essa categoria de material recebesse a denominação que tem hoje.

Todavia, o referido método propunha um uso bastante restrito para o tipo de material de que estamos tratando: empregava os textos literários apenas para ilustrar aspectos gramaticais da língua-alvo e para propor exercícios de tradução, deixando de lado tanto os aspectos sócio-histórico-culturais de tais textos quanto sua dimensão comunicativa.

Desse modo, é possível afirmar que o método gramática e tradução, apesar de propor o emprego de textos autênticos no ensino da língua-alvo, o faz de maneira bastante reducionista, ou seja, não explora o material autêntico - nesse caso, o texto literário - em toda a sua potencialidade, não o explora como valioso instrumento de ensinoaprendizagem da língua-alvo; apenas o utiliza como mero instrumento de ensino gramatical e de ensino de tradução.

\subsubsection{Método da leitura (Reading method)}

O método por meio do qual se visava desenvolver exclusivamente a habilidade de leitura e compreensão de textos foi elaborado na década de 1920 por alguns educadores ingleses e americanos. Na verdade, esse método é uma variante do método gramática e tradução: o reading method mantém a ideia de que aprender uma LE significa conhecer a sua gramática e ampliar os conhecimentos lexicais; além disso, mantém como principal referência a língua escrita. A diferença básica entre ambos os métodos consiste no fato de que o reading method restringe o objetivo do ensino-aprendizagem de uma língua-alvo ao desenvolvimento de uma única habilidade: a de compreensão escrita, o que revela uma visão meramente instrumental do processo de ensinar e aprender uma LE.

Como esse método concentra-se no desenvolvimento de uma única habilidade, sua aplicação leva, em geral, à obtenção de resultados rápidos, isto é, relativamente em pouco tempo, é provável que o aprendiz consiga ler textos escritos na língua-alvo. A obtenção de resultados rápidos faz com que tal método (e variantes dele) seja utilizado, até hoje, no 
ensino de línguas para fins específicos, como é o caso dos cursos instrumentais de línguas estrangeiras.

Estudar uma LE apenas para compreender textos escritos nessa língua equivale, segundo Piva (2000, p. 181), a "uma marginalização do interesse cultural que a L2 apresenta para o aprendiz, no sentido de que o aprendiz não pode aspirar a um maior conhecimento da $\mathrm{L}^{28}$ ".

No reading method, a língua utilizada no processo de ensino-aprendizagem é a língua materna dos alunos; as principais técnicas empregadas, nesse método, são: exercícios de leitura oral na língua-alvo, repetição frequente de palavras novas, exercícios focados no vocabulário e atividades para o desenvolvimento da capacidade de leitura extensiva (global) e de leitura intensiva (detalhada).

Na década de 1920, quando foi desenvolvido o método em questão, e nas décadas seguintes, os principais materiais utilizados nele eram textos construídos ad hoc, elaborados com base em uma visão graduada de aprendizagem: dos textos com estruturas mais simples àqueles com estruturas mais complexas. Portanto, tal método, inicialmente, não propunha a utilização de materiais autênticos, diferentemente do método gramática e tradução, que, de alguma forma, utilizava já um tipo de material autêntico (os textos literários). Além dessa, outra diferença entre ambos os métodos consiste no fato de que este emprega, praticamente, apenas textos literários, enquanto aquele passou a utilizar, em fases posteriores de seu desenvolvimento, diferentes tipos de materiais autênticos.

Atualmente, nos cursos de línguas estrangeiras instrumentais, muitas vezes, empregam-se textos autênticos de áreas específicas de interesse dos estudantes para o desenvolvimento da habilidade de compreensão escrita. Isso permite-lhes conhecer textos de tais áreas e familiarizar-se com eles, visando a compreendê-los em um espaço de tempo relativamente breve.

Assim, podemos dizer que o reading method, ao longo de sua evolução, no tocante ao emprego dos materiais, passou por modificações: inicialmente, propunha apenas o uso de textos elaborados ad hoc (didáticos, portanto, dentro da definição que mencionamos no capítulo 1) e, nos dias atuais, propõe, sobretudo, o emprego de textos autênticos. Tal mudança deve-se, talvez, ao fato de que os aprendizes que optam por fazer cursos de LE instrumentais, geralmente, têm o objetivo de ler e compreender, em um espaço de tempo

\footnotetext{
${ }^{28}$ No original: "una marginalizzazione dell'interesse culturale che la L2 riveste per l'apprendente, nel senso che l'apprendente non può aspirare ad una maggiore conoscenza della L2".
} 
relativamente curto, textos específicos de suas áreas de interesse, e o trabalho com textos autênticos, nesses cursos, pode facilitar o alcance de tal finalidade.

\subsubsection{Método direto}

A respeito do contexto histórico em que surgiu o método direto, Piva (2000, p. 181) afirma que:

Com o nome de método direto refere-se a uma série de métodos inicialmente conhecidos com nomes diversos (método reformado, método natural, método psicológico, método fonético); cada um dos quais, com características em comum, faz parte do amplo movimento de reforma do ensino das línguas estrangeiras que começou na Europa a partir da segunda metade do século passado $^{29}$ [o século XIX].

No final do século XIX, tanto na Europa quanto nos Estados Unidos, o ensinoaprendizagem de línguas estrangeiras passou a ser motivado por exigências práticas de comunicação entre diversos países. Consequentemente, o método gramática e tradução passou a ser criticado por teóricos da área de ensino de línguas (Berlitz, Sweet, Jespersen, Palmer): criticava-se esse método sobretudo pelo fato de ele não favorecer o desenvolvimento das habilidades de produção e compreensão oral dos alunos.

Segundo Larsen-Freeman (1997), o principal objetivo do método direto consiste em fazer com que os aprendizes tenham um contato direto com a língua estrangeira e possam se comunicar nela e que a aprendizagem da LE possa acontecer de forma quase tão natural quanto a da LM. Para tanto - afirma a autora -, acreditava-se que os alunos tivessem que aprender a pensar na língua-alvo, razão pela qual a aprendizagem da LE deveria ocorrer através da imersão do aluno no contexto de uso dessa língua. Essa imersão poderia ocorrer no contexto em que a língua estrangeira realmente era utilizada, ou por meio da simulação do contexto natural na sala de aula.

Enfatiza-se, primeiramente, a língua oral (falada por nativos), e não a escrita. Por isso, os alunos estudam a língua usual do dia a dia, e não a língua literária como no método gramática e tradução. Visando-se favorecer o contexto de imersão na língua-alvo e garantir que os aprendizes pudessem pensar na LE, o uso da língua materna deles era

\footnotetext{
${ }^{29}$ No original: "Col nome di metodo diretto ci si riferisce ad una serie di metodi inizialmente noti con nomi diversi (metodo riformato, metodo naturale, metodo psicologico, metodo fonetico), che rientrano tutti con caratteristiche comuni nell'ampio movimento di riforma dell'insegnamento delle lingue straniere avviatosi in Europa a partire dalla seconda metà del secolo scorso".
} 
abolido na sala de aula em que se empregava o método direto. Portanto, praticamente, nunca se faziam traduções para a LM dos discentes e, quando o professor pretendia introduzir uma palavra ou frase na língua-alvo, fazia-o por meio de realia ${ }^{30}$, mímicas ou figuras.

Nesse método, o ensino é baseado em situações (exemplos: "no banco", "no supermercado", "numa loja de roupas" etc) ou em temas (geografia, dinheiro, música, tempo atmosférico, entre outros). Jamais se apresentam regras gramaticais de forma explícita em tal método; a gramática é ensinada indutivamente. Desse modo, solicita-se aos aprendizes que utilizem a língua-alvo, e não que demonstrem seu conhecimento acerca dela. Além de estudar a LE, os alunos também estudam a cultura do povo que a fala.

Como o método direto dá grande ênfase à língua oral, para a eficácia de sua aplicação, acreditava-se que, preferencialmente, o professor de LE deveria ser um falante nativo da língua-alvo ou ter uma fluência na LE semelhante à do nativo (RICHARDS; RODGERS, 1986, p. 13), o que nem todos os docentes tinham. Esse foi um dos fatores que resultaram no declínio do referido método na década de 1930.

No que concerne aos materiais, o método direto propõe, sobretudo, a utilização de textos produzidos ad hoc, com os quais se faz uma série de atividades, tais como: leitura em voz alta e exercícios de ditado para o trabalho com a pronúncia correta; reconstrução do significado de cada palavra, recorrendo-se ao contexto e à associação de palavras e imagens, ou através do uso de paráfrases e sinônimos.

Contudo, o uso de materiais autênticos (bilhetes de trem, fotografias, artigos de jornal etc) também é proposto por tal método, pois, como já foi dito anteriormente, pretendia-se colocar o aluno em contato direto com a língua-alvo e com a cultura dos falantes nativos dessa língua, simulando situações reais de comunicação. Além disso, o uso de realia, uma categoria de material autêntico, era frequente para ilustrar vocábulos mais concretos, visto que, nesse método, não podiam ser feitas traduções para a língua materna dos alunos.

Diferentemente do reading method, que, como o próprio nome diz, emprega textos autênticos apenas para o desenvolvimento da habilidade de leitura, o método direto

\footnotetext{
30 "Realia: oggetti e altri materiali autentici usati nell'insegnamento di una lingua straniera". Definição retirada do Dizionario di Glottodidattica, de Balboni (1999). "Realia: objetos e outros materiais autênticos usados no ensino de uma língua estrangeira" (tradução nossa).
} 
utiliza-se desse tipo de material para o desenvolvimento das quatro habilidades linguísticas básicas (fala, escuta, leitura e escrita).

\subsubsection{Método audiolingual}

Esse método foi desenvolvido na Segunda Guerra Mundial pelo ASTP (Army Specialized Training Program), cuja elaboração deve-se ao linguista estruturalista americano Leonard Bloomfield: era o programa linguístico do exército americano, destinado à formação de tradutores militares e soldados que deveriam entrar em contato com as populações dos países liberados ou ocupados pelas tropas dos Estados Unidos. Tal programa consistia em aulas de dez horas diárias, ministradas seis vezes por semana por um falante nativo. O método em questão produziu excelentes resultados, porém estes decorreram, provavelmente, muito mais do contato intensivo com a língua-alvo do que de uma base metodológica bem desenvolvida.

Diferentemente do método direto, o método audiolingual possui uma base teórica de referência: a Linguística Estrutural. Ademais, é influenciado pelas teorias pedagógicas do Behaviorismo, que considera a língua como uma forma do comportamento humano e vê a aprendizagem de línguas como a aquisição de hábitos comportamentais.

Bloomfield é considerado o fundador da Linguística Estrutural norte-americana. Segundo essa teoria linguística, a língua é considerada um conjunto de sistemas de elementos estruturalmente relacionados para a codificação de sentido. Esses elementos, basicamente, são: fonemas, morfemas, palavras, frases e orações. O método audiolingual, que se valia da Linguística Estrutural como uma de suas bases científicas, postula que aprender uma língua significa ter o domínio de estruturas linguísticas e das regras por meio das quais os elementos estruturais se combinam.

O método em questão também apoiava-se na Psicologia Comportamental (ou Behaviorismo), que teve em Skinner seu principal representante. De acordo com esse teórico, o ser humano é capaz de produzir um repertório amplo de comportamentos, os quais dependem de três elementos essenciais na aprendizagem, isto é, o estímulo, a resposta e o reforço. Para Skinner, os comportamentos são selecionados através de três níveis:

- nível filogenético - que corresponde aos aspectos biológicos da espécie e da hereditariedade do indivíduo; 
- nível ontogenético: que está relacionado à história de vida do indivíduo;

- nível cultural: o conjunto de aspectos culturais que influenciam a conduta humana.

Segundo o Behaviorismo, todo comportamento seria aprendido através de condicionamento; portanto, a língua (que, dentro dessa concepção, é uma forma do comportamento) poderia ser aprendida por meio da formação de hábitos. Assim, pode-se dizer que o método audiolingual embasa-se em princípios da Linguística Estrutural e da Psicologia Behaviorista.

Dentro de tal método, está presente a convicção de que seja necessário e possível ensinar uma LE com bases científicas, que garantam a eficácia do ensino. Com tal método, Bloomfield conseguiu demonstrar que era possível ensinar línguas estrangeiras, em um curto espaço de tempo, mesmo para grupos numerosos de alunos.

Em virtude do sucesso do método, ele continuou a ser desenvolvido e difundido no pós-guerra, passando a ser amplamente usado no ensino de línguas em diversos contextos, e não mais apenas em contexto militar. O principal representante dessa nova fase foi Robert Lado, que sintetizou os aspectos do método em questão em quinze princípios gerais, a saber:

1) Devem ser desenvolvidas, primeiramente, as habilidades orais (fala e escuta) e, depois, as habilidades escritas (leitura e escrita).

2) Devem-se apresentar ao aprendiz estruturas sintáticas elementares.

3) A aprendizagem dá-se através da formação de hábitos: memorizam-se e repetem-se as estruturas para fixá-las como um hábito linguístico.

4) Aprende-se a pronúncia por meio da imitação e do emprego de exercícios fonéticos.

5) Não é necessário ampliar o vocabulário na primeira fase da aprendizagem; o importante é concentrar-se nas estruturas.

6) É preciso prestar muita atenção às estruturas, pois as dificuldades na aprendizagem de uma LE estão ligadas às estruturas diferentes daquelas da LM.

7) A língua escrita é introduzida sob a forma de transcrição de diálogos.

8) Os modelos de frases são apresentados progressivamente: parte-se sempre de uma estrutura já conhecida pelo aprendiz e acrescenta-se ou modifica-se um único elemento de cada vez.

9) Não se considera importante a tradução.

10) Utilizam-se modelos linguísticos autênticos: a língua é apresentada como se fala realmente e não como deveria ser falada. 
11) A maior parte do tempo da aula deve ser dedicada à prática de exercícios estruturais, que são a principal atividade a ser feita pelos alunos.

12) Devem ser feitos, nas aulas, exercícios progressivos que ajudem o aprendiz a construir determinados tipos de frases.

13) Os exercícios orais devem procurar imitar a velocidade natural da fala.

14) O professor deve reforçar positivamente a correta execução dos exercícios pelos estudantes.

15) Deve-se estimular a motivação dos aprendizes, fazendo-os identificar-se o máximo possível com a cultura do povo cuja língua estão estudando.

Os quinze princípios de Lado sintetizam as características do método em questão.

Dentre eles, interessa-nos, particularmente, no trabalho que aqui se apresenta, o décimo, pois, de certa forma, marca a presença da autenticidade no método audiolingual, embora esta tenha mais um caráter de autentificação do que de autenticidade propriamente dita: as aulas embasadas por esse método iniciam-se, geralmente, com a representação de uma situação da vida real; a situação pode ser representada por uma imagem (uma foto, por exemplo) ou por uma sequência de imagens. Pelas imagens, pode-se entender o contexto geral e o diálogo que se desenvolve na situação ilustrada. A presença de um elemento visual facilita a compreensão da situação pelos alunos e dá a ela um tom de autenticidade.

Os diálogos são compostos por frases autênticas pronunciadas por um falante nativo da língua-alvo, porém tais frases contêm exatamente as estruturas que devem ser apresentadas aos discentes durante a aula. Portanto, consistem em materiais autentificados, e não propriamente autênticos.

Os principais materiais utilizados no método audiolingual são os livros com exercícios estruturais (pattern drills), que podem ser de vários tipos, desde os que envolvem os aspectos fonético-fonológicos (trabalhados, sobretudo, no laboratório linguístico) até os que englobam os aspectos sintáticos. A memorização das frases, que constituem as unidades básicas de aprendizagem, e dos diálogos ocorre por meio de exercícios de repetição.

Dessa maneira, podemos dizer que o método audiolingual utiliza, principalmente, materiais didáticos, constituídos por exercícios elaborados ad hoc; no entanto, também propõe o emprego de materiais autênticos, ou melhor, de materiais autentificados, com cujo uso visa-se ensinar estruturas linguísticas aos discentes, o que representa uma utilização bastante reducionista dos materiais. 


\subsection{A presença (ou ausência) de materiais autênticos nos métodos alternativos de ensino de línguas estrangeiras}

Na década de 1960, o método audiolingual passou a sofrer severas críticas. Chomsky $(1965)^{31}$ foi um dos teóricos que mais criticou a Linguística Estrutural e o Behaviorismo, pilares que sustentavam tal método. Para esse estudioso, a Psicologia Comportamental não dava conta de explicar, de modo satisfatório, fenômenos linguísticos como a rápida aquisição da linguagem por crianças pequenas.

Além disso, de acordo, com a teoria da gramática transformacional, proposta por Chomsky, as propriedades fundamentais da língua provêm de aspectos inatos da mente, razão pela qual as orações não são aprendidas por imitação e repetição (como postulava a teoria behaviorista), mas são geradas pela competência subjacente do aprendiz.

No início da década de 1970, outro teórico que também contribuiu com a decadência dos métodos tradicionais de ensino, em particular do método audiolingual, foi Hymes (1972). Contudo, diferentemente de Chomsky, para quem a aquisição da língua por crianças pequenas estava relacionada apenas às suas estruturas mentais inatas, Hymes postula que a aquisição da língua também envolve fatores socioculturais; tal autor introduz, dessa maneira, o conceito de competência comunicativa.

Assim, segundo esse teórico, para que um falante seja comunicativamente competente, este não deve somente dominar as estruturas da língua, mas deve saber, também, como ela é utilizada pelos membros de uma comunidade linguística. Para tanto, esse falante deve ser capaz de produzir enunciados adequados ao contexto, viáveis em termos de processamento cognitivo (respeitando, por exemplo, limitações de memória), e plausíveis, ou seja, os enunciados devem corresponder ao uso da língua por seus falantes e não lhes causar estranhamento.

Desse modo, com a decadência do método audiolingual, por volta do final da década de 1960 e durante a de 1970, começaram a concretizar-se, na Europa e nos Estados Unidos, movimentos de contestação dos métodos tradicionais, em especial dos métodos gramática e tradução e audiolingual: na Europa, começou a desenvolver-se a abordagem comunicativa, e, paralelamente, nos EUA, desenvolveram-se os métodos

\footnotetext{
${ }^{31}$ O texto de Chomsky é de 1965, mas a tradução desse texto em cuja leitura nos baseamos para escrever o presente trabalho é de 1975.
} 
humanistas (ou alternativos) de ensino de LE. Discorreremos sobre a abordagem comunicativa mais adiante; agora, trataremos dos métodos humanistas.

Justamente porque se opunham aos métodos tradicionais, tais métodos ficaram conhecidos como métodos alternativos. Estes também são denominados métodos holísticos ou humanístico-afetivos, visto que, diferentemente dos tradicionais (que se concentravam muito mais nos resultados do ensino da LE do que no processo de aprendizagem), voltavam sua atenção à pessoa, ao ser humano, às características psicológicas dos aprendizes e aos problemas com os quais eles podem lidar durante seu percurso de aprendizagem linguística.

Todos os métodos alternativos apresentam, segundo Borneto (1998), as seguintes características em comum:

a) Supremacia da pedagogia: por terem sido desenvolvidos por psicólogos, pedagogos ou cientistas e, portanto, não por linguistas, os métodos alternativos atribuem uma importância menor aos aspectos linguísticos e focalizam sua atenção no aprendiz e no processo de aprendizagem da língua-alvo.

b) Centralidade do aprendiz: busca-se favorecer a aprendizagem da língua-alvo de forma não traumática, auxiliando o aprendiz a superar os obstáculos e a sentir-se motivado.

c) Multimodalidade: pluralidade de canais de aquisição de informações.

d) Infantilização: um dos aspectos mais criticados da didática alternativa reside no fato de que todos os métodos humanistas propõem um processo de infantilização do aprendiz, isto é, buscam simular a situação de aprendizagem típica das crianças que adquirem a L1 ou também uma L2.

e) Atmosfera não competitiva.

f) O professor como aquele que orienta as operações de aprendizagem linguística dos discentes.

A seguir, discorreremos brevemente sobre alguns dos principais métodos alternativos de ensino de línguas estrangeiras, a saber: Community Language Learning (método comunitário), Total Physical Response (resposta física total), Sugestopédia e Silent Way (método silencioso). Na breve descrição de cada um deles, tentaremos identificar a presença (ou ausência) dos materiais autênticos, tema que constitui o cerne deste capítulo. 
O método comunitário foi desenvolvido, em 1972, por Charles A. Curran, professor de psicologia da Loyola University de Chicago. Os referenciais teóricos do CLL são a Psicologia Humanista e a Psicoterapia do Counseling (aconselhamento, terapia centrada na pessoa), de Carl Rogers.

Curran foi aluno de Rogers e, ao desenvolver o método em questão, estabeleceu um paralelismo entre a Psicoterapia e o processo de aprendizagem: o aprendiz (learner) é considerado o paciente, e o professor de LE (knower), o conselheiro ou terapeuta. A relação entre ambos é decisiva no processo de ensino-aprendizagem da língua-alvo, para que o aluno supere os obstáculos que dificultam sua aprendizagem linguística; por isso, esta deve ocorrer num clima de aconselhamento terapêutico.

A terapia centrada na pessoa embasa-se na ideia de que os seres humanos interagem com o ambiente e, diante de ameaças, reagem defendendo-se. Essa terapia visa garantir que o paciente (o aprendiz) se sinta seguro, possa compreender a si mesmo e melhorar-se. Para tanto, o CLL, baseando-se nessas teorias de caráter psicológico, procura reproduzir o percurso da formação da personalidade, a partir de seu estágio infantil.

Dentro desse método, a personalidade e a segurança do estudante são reforçadas por meio da interação com outros aprendizes, considerados membros de uma mesma comunidade; daí deriva o nome do método. Nessa comunidade, todos tentam aprender uns com os outros e ajudar-se mutuamente. Portanto, é um método que propõe a cooperação, e não a competição. Os temas das aulas são escolhidos pelos próprios alunos, de acordo com seus interesses e com a sua participação emotiva, o que mostra que o CLL é um método em que o aprendiz é o centro do processo de ensinar e aprender uma línguaalvo.

A principal característica do CLL é a de tentar reproduzir, no processo de ensinoaprendizagem de uma LE, as fases de desenvolvimento da personalidade humana, desde o nascimento até a fase adulta: o método sustenta que aprender uma língua-alvo significa passar de uma situação passiva e receptiva (como a de um bebê) a uma situação de responsabilidade e capacidade de gerenciar e usar os próprios conhecimentos (como a de um adulto).

No Community Language Learning, a língua é vista como uma parte fundamental da maturação psicológica e do processo de socialização da personalidade, por isso é considerada um instrumento de comunicação. A pesquisa inicial de Curran era centrada na observação de pequenos grupos de estudantes universitários americanos para os quais 
ele pretendia ensinar, simultaneamente, quatro línguas estrangeiras: o francês, o espanhol, o alemão e o italiano.

Para atingir esse objetivo, o pesquisador utilizava a language alternation (alternância de línguas): os aprendizes formulavam uma frase na língua materna, e o professor traduzia-a, em voz baixa, para uma das línguas-alvo; tal frase em LE era repetida em voz alta pelo aprendiz e comunicada, assim, aos outros aprendizes. Estes, por sua vez, poderiam solicitar ao professor que a traduzisse para uma das outras línguas estrangeiras estudadas, ou poderiam formular outra frase na própria LM e pedir ao professor que a traduzisse, continuando, desse modo, a passar de uma língua à outra, com o auxílio do knower.

Nas aulas embasadas por tal método, os alunos sentam-se em círculo, de modo que todos possam se ver e se comunicar uns com os outros, e o professor fica atrás dos alunos, para não intimidá-los. Dessa forma, a principal habilidade exercitada no CLL é a expressão oral, e o conteúdo da aula é sempre escolhido pelos estudantes: são eles quem decidem sobre o que falarão. As principais técnicas empregadas nesse método são:

- a tradução de frases da LM para a LE;

- a repetição e gravação dessas frases ou de conversas pelos aprendizes;

- a transcrição de tais frases ou conversas pelo professor - os alunos podem copiar essa transcrição, e a coletânea de transcrições das conversas entre os discentes compõe o livro de texto de referência para a classe;

- $\quad$ análise - as transcrições são analisadas pelo grupo;

- atividades livres - em grupos, os estudantes podem elaborar novas frases, a partir das transcrições já realizadas; depois, podem apresentar as novas frases a toda a classe;

- reflexão e observação - concluídas as atividades, o professor solicita aos alunos que reflitam e falem sobre a experiência, podendo, para isso, usar a L1;

- conversação livre - os aprendizes participam de conversações livres com o professor ou com os outros discentes.

No tocante aos materiais utilizados no CLL, é possível dizer que, em tal método, não são empregados materiais autênticos, pois, como vimos, o material linguístico das aulas embasadas pelo Community Language Learning é construído durante as próprias aulas, isto é, são frases soltas e textos orais, que, depois, são transcritos pelo professor e copiados pelos aprendizes e que, ao final das aulas, constitui o livro de texto da classe. Tendo em vista que esse livro serve de referência para o grupo, talvez se possa afirmar que, de certa maneira, ele seria um livro didático, o qual, no entanto, diferentemente dos 
manuais didáticos convencionais, é confeccionado por seus próprios usuários. Portanto, no CLL, não estão presentes os materiais autênticos.

\subsubsection{Resposta física total (TPR - Total Physical Response)}

O TPR consiste, basicamente, em um método cujo pressuposto essencial é o de que se ensina e se aprende uma língua estrangeira por meio da "resposta física" a uma série de comandos verbais, isto é, por meio da associação entre a palavra e o movimento físico, o que ajuda a ativar o hemisfério direito do cérebro, podendo facilitar a aquisição da LE. O Total Physical Response foi desenvolvido, em 1977, por James Asher, professor de psicologia da Universidade de S. José, Califórnia.

Asher considera que o processo de aprendizagem de uma língua estrangeira é comparável ao da aprendizagem "natural" da língua materna na infância: na fase inicial de sua vida, a criança escuta e, antes de começar a expressar-se oralmente, responde com o olhar ou com gestos às palavras de seus pais, as quais, em geral, apresentam-se sob a forma de comandos e pedidos; assim, Asher acredita que, através da mesma modalidade, um adulto possa aprender uma LE. Ele acredita que a aprendizagem de uma língua-alvo envolva totalmente a pessoa, tanto mentalmente quanto fisicamente: o comando é dado verbalmente, mas a resposta a tal comando é física; daí deriva o nome do método.

De acordo com o TPR, assim como a criança passa por uma longa fase de silêncio, em que escuta, entende e reage fisicamente, mas não fala, o aprendiz de uma LE (adulto) também deve passar por uma longa fase de escuta silenciosa, na qual não lhe seja solicitado falar. A produção oral se desenvolverá de modo espontâneo, quando essa fase estiver estabilizada.

Quanto aos aspectos linguísticos, no método em questão, a língua é considerada, quase exclusivamente, como código oral: por ser um método baseado no modelo de aquisição da L1 na infância, não reserva muito espaço à modalidade escrita da língua, nem sob a forma de leitura, nem sob a forma de escrita. No programa didático do TPR, as habilidades escritas são vistas como secundárias, como uma consolidação final do que já foi adquirido oralmente.

Com relação ao nível lexical, o TPR divide a língua em abstractions e nonabstrations, isto é, elementos abstratos e não abstratos; os primeiros são os substantivos que representam conceitos abstratos, já os segundos consistem em 
substantivos concretos e verbos no imperativo. Para Asher, num momento inicial do processo de ensino-aprendizagem de uma LE, os aprendizes podem adquirir conhecimento e competência suficientemente completos e detalhados da língua-alvo através de elementos concretos, sem recorrer às abstrações. Em um momento posterior, os elementos abstratos podem ser introduzidos e explicados na LE, visto que os alunos já terão interiorizado o código linguístico.

A aula embasada por tal método tem um ritmo rápido e deve ser minuciosamente preparada pelo professor. No TPR, os alunos não têm muita influência no que se refere ao desenvolvimento da aula e à apresentação dos seus conteúdos. Essa aula tem, em geral, as seguintes fases:

- revisão - uma retomada da aula anterior, em que são exercitados velhos comandos e suas respectivas ações;

- novos comandos;

- recombinação - nessa fase, podem ser introduzidas formas e frases complexas, que não se limitam ao uso do imperativo;

- material novo - o professor introduz novo material linguístico, por meio da descrição de suas próprias ações;

- revisão do novo material - uma fase muito dinâmica, na qual todos os comandos e ações exercitados na aula são repetidos e recombinados em forma de uma brincadeira muito rápida;

- leitura e escrita - essa fase raramente ocorre, pois, como já foi dito, o TPR enfatiza as habilidades orais.

No que concerne aos materiais empregados no TPR, pode-se dizer que não há, nesse método, um texto-base de referência. Visciola (1998, p. 76) salienta que:

No estágio inicial da aprendizagem, são suficientes a voz do professor, o conjunto de gestos que o movimento físico implica e os objetos encontrados na sala em que se desenvolvem as aulas (canetas, cadernos, cadeiras, bancos). Em seguida, faz-se uso de imagens, slides, realia, para fornecer um suporte visual aos temas a serem apresentados durante a aula ${ }^{32}$.

Além desses, outros materiais usados no Total Physical Response são os student kits, uma criação de Asher: um conjunto de materiais que representam diversos cenários em miniatura (a casa, a cozinha, a sala, o aeroporto, o banco, a escola etc). A utilização

\footnotetext{
${ }^{32}$ No texto original: "Allo stadio iniziale dell'apprendimento sono sufficienti la voce dell'insegnante, l'insieme dei gesti che il movimento fisico implica e gli oggetti reperibili nell'aula in cui si svolgono le lezioni (penne, quaderni, sedie, banchi). In seguito, viene fatto uso di immagini, diapositive, realia, per fornire un supporto visivo agli argomenti da presentare durante la lezione".
} 
desses kits não requer movimentos físicos e permite ao aprendiz responder, de seu lugar, aos comandos do professor, manipulando os elementos autoadesivos nos respectivos cenários.

No tocante aos materiais autênticos, portanto, é possível afirmar que, no TPR, esse tipo de material é pouquíssimo utilizado: em linhas gerais, o material autêntico faz-se presente, nesse método, apenas sob a forma de realia.

\subsubsection{Sugestopédia}

Em 1979, Georgi Lozanov, médico e psicoterapeuta búlgaro, desenvolveu um método de ensino de línguas estrangeiras que, por meio da aprendizagem inconsciente, permitisse explorar, de maneira eficaz, as capacidades de aprendizagem e de memorização da mente humana. Nasceu, desse modo, a sugestopédia, apresentada ao público como um método para cursos intensivos e destinado a adultos. Lozanov declarava, abertamente, que se utilizava da sugestão e da aprendizagem inconsciente em sua prática didática. As ideias principais que constituem a base desse método são estas:

a) Sugestão/autossugestão: segundo Lozanov, as pessoas, desde a infância, são sugestionadas, isto é, condicionadas a comportamentos para adaptarem-se à realidade social em que vivem. Esse condicionamento reduz a criatividade e a flexibilidade mental do indivíduo, o que dificulta a aquisição de novos conhecimentos, entre os quais os linguísticos. Assim, a tarefa do professor que utiliza o método em questão seria a de levar o aprendiz à autossugestão, isto é, livrá-lo das suas influências negativas, para, em seguida, sugestioná-lo de maneira positiva com relação à aprendizagem. Tal aspecto dá nome ao método: sugestopédia é um vocábulo composto pelas palavras sugestão e pedagogia.

b) Elaboração consciente e inconsciente: o método busca favorecer a aquisição inconsciente da língua-alvo (por meio do jogo e da intervenção da música) e a aprendizagem consciente (através do estudo lexical, gramatical, de traduções etc).

c) Utilização da música: Lozanov acreditava que a música, principalmente barroca, produzia dois efeitos importantes no processo de ensino-aprendizagem da LE, ou seja, a criação de uma atmosfera tranquila e adequada às "sugestões positivas" que facilitam a aprendizagem e a ativação do hemisfério direito do cérebro. 
No que concerne aos aspectos linguísticos, na sugestopédia, dá-se muito mais importância ao vocabulário do que à gramática, por isso, propõe-se o uso de textos longos nas aulas, para enriquecer o vocabulário dos alunos. Como os textos longos podem trazer problemas de compreensão, sobretudo para os aprendizes de níveis iniciais de estudo da LE, Lozanov propõe que cada texto seja acompanhado por sua respectiva tradução para a L1 do aluno.

Quanto aos aspectos didáticos, as aulas embasadas pelo referido método dividemse, basicamente, em duas partes: a apresentação do material linguístico e a ativação dos conhecimentos linguísticos. A primeira parte divide-se em:

1. Introdução - o professor procura criar uma atmosfera tranquila na sala de aula, valendo-se de exercícios de relaxamento. Depois, tenta evocar nos aprendizes aquilo que eles já sabem da língua-alvo e, em seguida, lê o texto em voz alta para os alunos, faz mímicas para que eles compreendam o texto lido e o traduz inteiramente, frase por frase.

2. Reprodução - o professor relê o texto e faz mímicas, como na introdução; os aprendizes devem repetir o texto em coro e imitar os gestos do professor.

3. Concerto ativo - também chamado de fase analítica; nessa parte da aula, o professor entrega aos alunos o texto escrito e sua respectiva tradução e faz a leitura do texto em voz alta, ao som de uma música adequada à atmosfera do texto que será trabalhado na aula.

4. Concerto passivo ou fase associativa - os aprendizes são relaxados e escutam, novamente, o texto lido pelo professor, mas, agora, ao som de música barroca.

A segunda fase, a da ativação, consiste na parte da aula em que são tratados os aspectos gramaticais e em que é promovida a produção linguística dos alunos. É composta por duas fases de exercícios: na fase inicial, os estudantes analisam, modificam e exploram o texto (da fase da apresentação do material linguístico) em atividades realizadas em duplas ou em grupos; na última fase, promove-se a comunicação livre entre os aprendizes, que participam de exercícios dinâmicos, como jogos e comunicações em contextos reais.

Com relação às técnicas empregadas na sugestopédia, as principais são: a mudança de identidade (na primeira aula, os alunos e o professor assumem cada qual uma identidade fictícia; geralmente, a de um dos personagens do texto que será lido), a utilização da música, as técnicas de relaxamento e de visualização, a gestualidade e os jogos. 
No que se refere aos materiais usados nesse método, o principal deles consiste em um livro de textos, constituído, geralmente, por dez unidades; cada qual contém um diálogo longo, com cerca de duzentas a quatrocentas palavras; cada diálogo é acompanhado por sua respectiva tradução, por algumas explicações gramaticais e, às vezes, por material complementar (pequenos textos referentes ao país cuja língua é objeto de estudo dos aprendizes e sobre a cultura do povo falante nativo de tal língua). Assim, nota-se que, na sugestopédia, o material central é o material didático.

Apesar dessa centralidade do material didático, podemos dizer que o material autêntico, ainda que de forma muito discreta, também marca sua presença nesse método: na terceira fase da primeira parte da aula sugestopédica, ou melhor, na fase do concerto ativo, o professor lê em voz alta o texto didático para os alunos, ao som de uma música que tenha relação com a atmosfera do texto. Essa música pode ser de algum cantor do país cuja língua os aprendizes estudam e, portanto, consiste em um material autêntico, ou seja, produzido sem finalidades didáticas. A respeito da música a ser utilizada no concerto ativo, Giardini (1998, p. 102) ressalta que:

Lozanov e Gateva (1983) e Schuster e Gritton (1986) dão indicações quanto aos trechos musicais preferíveis, mas, na realidade, podem-se escolher, também, canções diversas - por exemplo, originárias do país de que se aprende a língua contanto que se tenha verificado anteriormente quais sensações suscitam no público e se tais músicas são de seu agrado. Deve-se sempre lembrar que a música escolhida para essa fase deveria ser considerada alegre, clara, estimulante e agradável ${ }^{33}$.

Portanto, é possível afirmar que, de algum modo, o material autêntico também é empregado nesse método alternativo de ensino de línguas estrangeiras do qual acabamos de tratar. Tendo em vista que a música é um elemento muito importante na sugestopédia, talvez possamos, então, dizer que esse tipo de material autêntico tem um papel relevante em tal método.

\subsubsection{Método silencioso (SW - Silent Way)}

\footnotetext{
${ }^{33}$ No original: "Lozanov e Gateva (1983) e Schuster e Gritton (1986) danno indicazioni in merito ai brani musicali da preferire, ma in realtà si possono scegliere anche motivi diversi-per esempio originari del paese di cui si impara la lingua - purché si sia verificato in precedenza quali sensazioni suscitano e quale sia il gradimento presso il pubblico. Va tenuto sempre presente che la musica scelta per questa fase dovrebbe essere recepita come allegra, chiara, stimolante e piacevole".
} 
O método silencioso foi criado e desenvolvido, em 1972, por um pedagogo egípcio, Caleb Gattegno. Como não era um linguista, Gattegno desenvolveu, inicialmente, suas reflexões sobre os problemas do ensino-aprendizagem em geral, partindo da ideia de que a aprendizagem não ocorre por imitação, como defendiam os behavioristas. Esse pedagogo sustenta que cada pessoa deve procurar, dentro de si mesma, as respostas para as perguntas que qualquer tipo de aprendizagem coloca. Por causa dessa sua visão acerca do processo de ensino-aprendizagem, Gattegno é considerado cognitivista, embora o SW seja enquadrado nos métodos humanistas.

No âmbito da pedagogia de línguas, o método criado por Gattegno caracteriza-se por instrumentos técnicos muito específicos e, sobretudo, diferentemente dos demais métodos alternativos de ensino de línguas estrangeiras, por não se preocupar com os aspectos afetivos do aprendiz: o SW enfatiza o potencial intelectual do aluno, que é posto constantemente sob tensão, o que pode suscitar emoções e sentimentos negativos no estudante.

Uma das características essenciais do método e da qual deriva o seu nome é o uso do silêncio. Gattegno tinha notado que alguns professores falavam muito durante as aulas, não permitindo que os aprendizes tivessem tempo e possibilidade de elaborar suas próprias estratégias de aprendizagem. Para esse teórico, falar significa indicar modelos e antecipar soluções. Por isso, ele acredita que o professor deve ficar em silêncio e jamais deve intervir, mas deve estimular, por meio de gestos e outros instrumentos, a atividade verbal e intelectual dos discentes. Ao mesmo tempo, esse pedagogo defende a ideia de que o professor deve propiciar a interação entre os aprendizes, dirigindo-a e fornecendo estímulos que provoquem o esforço mental dos alunos.

Quanto aos aspectos linguísticos, o autor do SW não acredita que as teorias linguísticas ajudem no processo de ensino-aprendizagem de uma LE, pois a seu ver, a língua é um substituto da experiência, ou seja, um instrumento ao qual a experiência dá conteúdo e substância.

Além disso, Gattegno acredita que cada língua tenha o seu próprio "espírito", que é muito influenciado pelo sistema fonético de cada uma: os sons de uma língua são o aspecto que mais a diferencia das outras e caracteriza-a em sua especificidade. Por isso, o método criado por Gattegno dá grande ênfase à pronúncia e à entonação, que são introduzidas por meio de instrumentos específicos em que os sons são associados às cores, de modo que fiquem impressos na memória e sejam mais facilmente assimilados pelo sistema cognitivo do aprendiz. 
No método silencioso, aprender uma LE é considerado um processo bastante artificial, para a realização do qual se deve, portanto, explorar tudo aquilo que já se sabe da primeira língua (a L1 pode, então, ser usada nas aulas); trata-se de um processo que não é automático nem inconsciente, mas sim, que requer conscientização e controle.

No que concerne ao léxico, o SW distingue o "vocabulário funcional" do "vocabulário de luxo": o primeiro é composto pelas palavras gramaticais (gramemas, isto é, preposições, artigos, conjunções etc) e por algumas palavras largamente utilizadas na comunicação; o segundo constitui-se por palavras lexicais (lexemas, ou seja, substantivos, adjetivos, verbos etc), que servem para enriquecer a comunicação.

Com relação aos materiais, o Silent Way emprega instrumentos didáticos específicos, criados pelo próprio Gattegno, a saber:

- a batuta - semelhante à utilizada por um maestro, serve para indicar sons e palavras nas tabelas e para solicitar que os alunos falem;

- os bastões coloridos - pequenos bastões de diferentes dimensões e cores utilizados para fixar o vocabulário, ampliá-lo, induzir e imitar diversas situações;

- a tabela fonética - uma tabela preta que contém retângulos coloridos, representando cada qual um som da língua-alvo;

- a tabela Fidel para as grafias - uma tabela com letras coloridas; cada letra tem a cor correspondente ao som aprendido na tabela fonética;

- a tabela com o "vocabulário funcional";

- os desenhos - dez desenhos sobre temas recorrentes (casa, família, escola etc) que servem para ampliar o "vocabulário de luxo";

- livros com exercícios de leitura e escrita.

Tais livros são de dois tipos: as Mil frases e as leituras breves (short passages). As Mil frases são, no método silencioso, o primeiro exercício de leitura na língua-alvo. Segundo Gattegno, por causa de sua limitada competência na LE, os aprendizes dos níveis iniciais não têm condições de enfrentar a leitura de um texto longo e complexo; por isso, o pedagogo que desenvolveu o SW criou essa coletânea de frases, agrupadas por temas, entre os quais: a casa, a comida, o trabalho, a família, a instrução etc.

As leituras breves, por sua vez, consistem em textos que constituem, na visão de Gattegno, uma passagem intermediária e necessária do percurso do aprendiz em direção à sua autonomia, entendida como a capacidade de compreender qualquer texto escrito na língua-alvo com as mesmas modalidades com as quais compreenderia um texto escrito 
em sua língua materna. Acerca dos textos para as leituras breves empregados no método silencioso, Pontesilli (1998, p. 127) afirma que:

Embora estes também sejam criados ad hoc, diferentemente do que ocorre com as Mil frases, o vocabulário e a sintaxe dos textos não são sujeitos a qualquer tipo de seleção ou restrição. $\mathrm{O}$ único tipo de controle é relativo à extensão do texto proposto (entre 200 e 900 palavras). Os assuntos são diversos: temas sociais, trabalho, viagens, eventos naturais, curiosidades etc ${ }^{34}$.

Ao lermos a afirmação acima, fica claro que os livros utilizados no SW, assim como os instrumentos específicos empregados nesse método, fazem parte da categoria dos materiais didáticos. No entanto, quando Pontesilli comenta que as leituras breves são textos que não são sujeitos a nenhum tipo de seleção ou restrição, podemos reconhecer aqui, talvez, uma tentativa, por parte de Gattegno, de autentificar o material, isto é, de aproximá-lo dos textos autênticos, ou melhor, de torná-los parecidos com os textos que circulam no universo de leitura dos falantes nativos da língua que é objeto de estudo dos aprendizes.

Parece-nos possível dizer, portanto, que, no método silencioso, embora não se utilizem materiais autênticos, empregam-se não só materiais didáticos, como também materiais autentificados.

\subsection{A utilização de materiais autênticos na abordagem comunicativa}

Como vimos, a incessante busca pela melhor maneira de ensinar línguas estrangeiras, bem como o descontentamento de teóricos da pedagogia de línguas e de professores de LE com os métodos tradicionais de ensino levaram ao desenvolvimento dos métodos humanistas nos Estados Unidos e da abordagem comunicativa na Europa. Apesar de os métodos alternativos de ensino de línguas não terem tido uma grande repercussão, forneceram alguns pressupostos importantes para o movimento comunicativo: a partir de tais métodos, os aspectos psicológicos e afetivos do aprendiz passaram a ser considerados tão importantes quanto os seus aspectos cognitivos, e o foco do processo de ensino-aprendizagem deslocou-se do professor e do ato de ensinar para o aluno e a aprendizagem.

\footnotetext{
${ }^{34}$ No original: "Sebbene anche questi siano creati ad hoc, a differenza di quanto avviene per le Mille frasi il vocabolario e la sintassi dei brani non sono soggetti ad alcun tipo di selezione o restrizione. L'unico tipo di controllo è relativo alla lunghezza del testo proposto (tra le 200 e le 900 parole). Gli argomenti sono diversi: temi sociali, lavoro, viaggi, eventi naturali, curiosità ecc".
} 
A abordagem comunicativa nasceu no início da década de 1970, contrapondo-se aos métodos tradicionais então dominantes (em especial, ao método gramática e tradução e ao audiolingual). Chomsky, embora tenha desautorizado a aplicação de sua teoria ao ensino de línguas, contribuiu com as mudanças que levaram ao desenvolvimento da abordagem comunicativa, criticando a aplicação da teoria behaviorista ao ensino de línguas estrangeiras. Esse estudioso opõe-se a essa teoria, fazendo duras críticas ao postulado de que a aprendizagem somente ocorre mediante estímulo, resposta e reforço.

Para o linguista americano, as teorias estruturais não davam conta de responder pelas características fundamentais das línguas, isto é, a criatividade e a singularidade de orações individuais. Entretanto, a teoria de Chomsky apresenta uma característica fundamental em comum com a Linguística Estrutural: a importância dada ao estudo da estrutura da língua.

Por isso, a teoria desse linguista também foi criticada por vários autores, entre os quais Hymes (1972): enquanto aquele estudioso afirma que a competência é um processo inato de produção de sentenças gramaticalmente corretas, Hymes defende a ideia de que a competência deve ser ensinada como prática social de linguagem. Ele introduz, assim, o conceito de competência comunicativa, que, basicamente, consiste na utilização, pelo falante/ouvinte, de todo o conhecimento necessário, do ponto de vista sociolinguístico, cultural e pragmático, para interagir nas mais diversas situações de uso da língua.

Além de Hymes, outro teórico que muito contribuiu para o desenvolvimento da abordagem comunicativa foi Wilkins que, em 1972, publicou um documento no qual propunha uma definição funcional ou comunicativa de língua baseada em funções que são necessárias ao aprendiz de uma LE, para que ele possa compreender a língua-alvo e saber expressar-se por meio dela. Para esse teórico, estas são de dois tipos: categorias semântico-gramaticais e categorias de funções comunicativas.

Em 1976, Wilkins revisou e expandiu esse documento, publicando um livro cujo título é Notional Syllabuses, considerado o marco do movimento comunicativo funcional. Em tal obra, o autor discute três abordagens de ensino, a saber: gramatical, situacional e nocional, explicitando as limitações das duas primeiras e as vantagens propiciadas pela última.

Todavia, o livro de Wilkins também foi criticado por outros teóricos, entre os quais Widdowson (1978), que afirma que o autor de Notional Syllabuses apresenta, nessa obra, listas de funções isoladas, do mesmo modo que um planejamento estrutural apresenta as unidades gramaticais. 
De acordo com Widdowson, o planejamento nocional não apresenta a linguagem como discurso, não podendo, portanto, desenvolver a competência comunicativa do aprendiz. Para esse autor, tal competência refere-se a um conjunto de estratégias ou procedimentos criativos utilizados para realizar os valores dos elementos linguísticos em contextos de uso.

Esse teórico sustenta que o foco da atenção do planejamento nocional está em itens, e não em componentes do discurso e no processo de sua criação; dessa forma, ele acredita que esse planejamento não difere, essencialmente, do planejamento estrutural, visto que este também lida com itens.

No entanto, embora aponte algumas limitações do planejamento nocional proposto por Wilkins e postule que ainda há muito a ser feito no âmbito da pedagogia de línguas, Widdowson considera que a mudança de enfoque das orações para as funções/noções representa já um avanço significativo em tal âmbito.

Depois da obra de Wilkins, foram publicadas muitas outras que também forneceram as bases teóricas do movimento comunicativo, entre as quais a de Canale e Swain (1980) e a de Canale (1983).

Na obra de 1980, esses dois autores redefinem o conceito de competência comunicativa, que já fora tratado por Hymes e Widdowson. Assim, em tal obra, Canale e Swain, postulam que a competência comunicativa abrange três componentes, que devem ser igualmente enfatizados no processo de ensino-aprendizagem de uma língua-alvo. Tais componentes são:

- a competência gramatical - que implica a habilidade de reconhecer as características da língua e utilizá-las para formar palavras e frases;

- a competência sociolinguística - a qual diz respeito ao conhecimento das regras sociais que norteiam o uso da língua;

- a competência estratégica - que se refere às estratégias utilizadas pelo falante para compensar qualquer imperfeição no conhecimento das regras.

Em 1983, Canale revisou e redefiniu o modelo acima, adicionando-lhe a competência discursiva. Para esse teórico, tal competência envolve a conexão de uma série de orações e frases com a finalidade de constituir um todo significativo a ser partilhado pelo falante/escritor e ouvinte/leitor. O autor ressalta, ainda, que as quatro competências devem ser trabalhadas nas aulas de LE, desfazendo, dessa maneira, a interpretação equivocada de que, na abordagem comunicativa, o componente gramatical deva ser ignorado. 
Embasando-se em conceitos propostos por Hymes (1972), Wilkins (1976), Widdowson (1978), Canale e Swain (1980), Canale (1983) e outros estudiosos (como os filósofos da linguagem Austin e Searle), a abordagem comunicativa, ao contrário dos métodos tradicionais, dá muito mais ênfase à comunicação do que à gramática e às estruturas linguísticas. Como já mencionamos, isso não significa, contudo, que a abordagem comunicativa deixe de lado o desenvolvimento da competência gramatical.

O objetivo central do processo de ensino-aprendizagem, nessa abordagem, consiste em fornecer aos alunos os instrumentos necessários, do ponto de vista sociolinguístico, cultural e pragmático, para que eles possam interagir ativamente nas mais diversas situações de uso da LE. Esse objetivo refere-se à competência de ação, ou seja, ao "saber fazer com a língua" (saber utilizá-la, efetivamente, em situações de comunicação real).

Com o intuito de alcançar tal objetivo, propõe-se que, nas aulas embasadas por essa abordagem, a disposição dos móveis da sala de aula favoreça, o máximo possível, a interação entre os alunos; por esse motivo, geralmente, estes sentam-se em semicírculo, ou em pequenos grupos, conforme as tarefas propostas pelo professor.

O docente utiliza, nas aulas, exclusivamente (ou quase exclusivamente), a línguaalvo e solicita, aos aprendizes, que falem, também, nessa língua; porém em classes monolíngues e nas quais o professor conhece a LM dos estudantes, ele mostra-se tolerante quanto ao uso da L1 pelos alunos. Assim, a abordagem comunicativa mostra-se flexível, no que concerne à aceitação da língua materna dos estudantes.

Essa abordagem desenvolveu-se ao longo de quase trinta anos e tornou-se uma referência indispensável na didática das línguas estrangeiras. A respeito da importância da abordagem comunicativa, Borneto (1998, p. 131) ressalta que "hoje em dia, não existe, praticamente, uma abordagem que não seja influenciada pela abordagem comunicativa nas premissas ou na prática ${ }^{35}$ ".

Em sua fase inicial de desenvolvimento, a abordagem comunicativa, visando combater os métodos tradicionais de ensino de línguas, apresentava os seguintes princípios:

1. Grande atenção aos usos da língua: as formas linguísticas são apresentadas aos estudantes não apenas em seu aspecto sistemático, mas também (e principalmente) em

\footnotetext{
${ }^{35}$ No original: “(...) oggigiorno non esiste praticamente approccio che non ne sia influenzato nelle premesse o nella pratica".
} 
relação às funções que elas exercem em diversos tipos de comunicação, de acordo com o grau de formalidade da situação comunicativa e com as intenções do falante.

2. Autenticidade do material linguístico: a língua-alvo é o máximo possível autêntica, ou seja, corresponde àquela que se pode encontrar em situações reais de comunicação. Privilegia-se, assim, o uso de materiais autênticos no processo de ensinoaprendizagem da língua-alvo, tais como: textos extraídos de revistas e jornais, gravações de conversas ou de programas de rádio e TV, convites, publicidades, canções etc; ou seja, evita-se o emprego de frases e textos elaborados ad hoc, que, como vimos, eram muito utilizados tanto em métodos tradicionais quanto em métodos alternativos de ensino de LE.

3. Progressão e unidade didática ${ }^{36}$ : na abordagem comunicativa, nasce o conceito de unidade didática, entendida como conjunto coerente de conteúdos, formas linguísticas, informações culturais, práticas de interação, exercícios etc. Assim, a progressão dos temas didáticos não se baseia mais em critérios gramaticais, e sim, em conteúdos e funções que se pretendem trabalhar com os aprendizes.

4. Diferenciação da oferta didática: a abordagem propõe uma série de cursos diferenciados, que atendam às diversas exigências dos alunos; surgem, então, cursos de LE para fins acadêmicos, profissionais, entre outros.

5. Papel ativo do aprendiz: desde o início das aulas, incentiva-se o aprendiz a interagir com seus colegas para participar de situações comunicativas reais ou para simular tais situações. Por isso, dramatizações, role play, atividades em duplas ou em grupos e jogos tornam-se atividades constantes na classe.

Em suas fases subsequentes, a abordagem comunicativa manteve todos esses (ou quase todos) princípios fundamentais. De acordo com alguns teóricos ${ }^{37}$, tal abordagem, ao longo de seu desenvolvimento, recebeu várias interpretações, razão por que se pode falar em movimento comunicativo. Esse movimento materializa-se em diversas tendências metodológicas, entre as quais:

- comunicativizadas - nestas, não se discutem as concepções fundamentais da abordagem comunicativa, mas apenas propõem-se algumas atividades baseadas no "saber fazer com a língua";

- funcionalizadas - organizam o ensino da LE com base em listas de funções;

\footnotetext{
${ }^{36}$ Segundo Borneto (1998), o conceito de unità didattica (unidade didática) vem cedendo lugar a um conceito mais flexível na área da pedagogia de línguas: o conceito de unità di apprendimento (sequência didática).

${ }^{37}$ Cf. os textos, citados neste capítulo, de Almeida Filho, Borneto e Scalzo.
} 
- críticas - consideram importantes todos os elementos constituintes do processo de ensino-aprendizagem da língua-alvo (o aprendiz, o professor, a LE, os materiais etc) e preocupam-se com as reflexões teóricas a respeito da abordagem comunicativa, por isso veem o aluno como sujeito histórico e visam promover a aprendizagem através da construção de um discurso histórico-crítico;

- espontaneístas - dizem respeito ao equívoco de que o professor comunicativo é espontâneo e não precisa planejar suas aulas.

No tocante ao papel do aluno, sabemos que, na abordagem comunicativa, apesar de ser favorecida a interação social, através de atividades em duplas e em grupos, buscase sempre respeitar a personalidade de cada aprendiz, bem como suas preferências de estudo, suas estratégias de aprendizagem, suas motivações, seu ritmo; enfim, o discente é visto como o centro do processo de ensino-aprendizagem da língua-alvo e respeitado em sua singularidade.

Quanto ao papel do professor, pode-se afirmar que a ele compete ativar e apoiar a atividade individual e autônoma do aprendiz, ou seja, o "professor comunicativo" é considerado um "facilitador" da aprendizagem.

No que concerne aos materiais, Richards e Rodgers (1986, p. 168) afirmam que, dentro da abordagem comunicativa, os materiais autênticos têm "o papel primário de

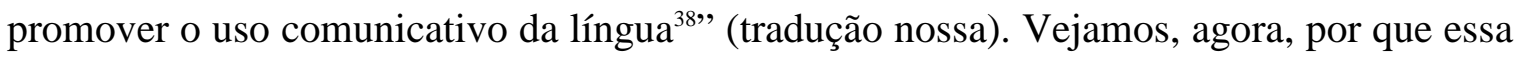
abordagem defende a utilização dos textos autênticos em âmbito glotodidático.

Por enfatizar a importância dos usos da língua no processo de ensinoaprendizagem da LE, a abordagem comunicativa propõe que se deve ensinar a "língua em uso", isto é, a língua utilizada em conversações espontâneas entre falantes nativos. Segundo Scalzo (1998, p. 145):

Trata-se de uma língua verdadeira, autêntica, não atenuada por experimentos de laboratório linguístico, caracterizada pela presença de expressões idiomáticas e coloquiais e por "defeitos" da performance, como falsas partidas, hesitações, lapsos, anacolutos etc (no caso da língua falada) ${ }^{39}$.

A autora ressalta que é sobretudo esse tipo de língua que deve ser proposto em uma classe "comunicativa", pois é esse tipo de língua que os aprendizes encontrarão em

\footnotetext{
${ }^{38}$ No texto original: "(...) the primary role of promoting communicative language use".

${ }^{39}$ No original: "Si tratta di una lingua vera, autentica, non edulcorata da esperimenti di laboratorio linguistico, caratterizzata dalla presenza di espressioni idiomatiche e colloquiali, e da 'guasti' della performance quali false partenze, esitazioni, lapsus, anacoluti ecc (nel caso della lingua parlata)".
} 
situações reais de comunicação com falantes nativos da língua-alvo. Ela explica que vem daí a necessidade e a importância de se empregarem materiais autênticos nas aulas.

A afirmação de Scalzo faz-nos pensar em um aspecto inovador da abordagem comunicativa, quanto ao uso dos materiais autênticos: o emprego de textos autênticos orais espontâneos no processo de ensino-aprendizagem da LE (e não mais textos orais produzidos ad hoc, como em alguns métodos tradicionais e alternativos).

Contudo, na abordagem comunicativa, raramente é mencionado o emprego de textos autênticos que não tenham um caráter de textos do cotidiano, como os textos literários, que, na história dos métodos e abordagens de ensino de línguas estrangeiras, são, possivelmente, os materiais autênticos mais "antigos", no sentido de que talvez tenham sido os primeiros materiais não didáticos a serem utilizados no processo de ensino-aprendizagem de uma LE. Apesar disso, excertos de tais textos também podem ser encontrados em alguns livros didáticos publicados nos últimos anos.

Dessa maneira, podemos dizer que a abordagem comunicativa, para combater a artificialidade de frases inventadas e de textos elaborados ad hoc, presentes tanto em métodos tradicionais quanto em métodos alternativos de ensino de línguas, propõe a utilização de diferentes materiais autênticos, e, especialmente daqueles que ilustram a "língua em uso"; porém, ao privilegiar o uso de materiais autênticos que são mais facilmente encontrados em situações reais de comunicação corriqueira (conversações, textos de jornal, de revistas etc), coloca em posição secundária outros tipos de materiais autênticos, como os textos literários. 


\section{O PROCESSO DE DIDATIZAÇÃO DE MATERIAIS AUTÊNTICOS}

Neste capítulo, nosso objetivo consiste em explicar o que significa didatizar materiais autênticos, visando à sua utilização nas aulas de língua estrangeira. Para tanto, retomaremos a definição de didatização apresentada no capítulo 1 e discorreremos sobre algumas técnicas didáticas e alguns conceitos da Linguística Textual importantes no processo de didatização desses materiais.

\subsection{O que é didatização?}

Em seu texto "Didattizzazione di materiali autentici e analisi dei manuali di italiano per stranieri", Begotti (s. d: 4$)^{40}$ afirma que "entre as competências exigidas de um professor encontra-se, certamente, a capacidade de didatizar materiais autênticos para os próprios estudantes ${ }^{41}$ ". A autora afirma, também, que a didatização é um processo árduo e complexo, para a realização do qual não basta criar alguns exercícios de forma improvisada. Entretanto, essa estudiosa não explica, de maneira explícita, o que ela chama de didatização.

Aliás, não apenas Begotti, como também outros teóricos, entre os quais Balboni (1994), Mezzadri (2003), Spinelli (2003) e Bonvino (2008), como dissemos no capítulo 1 desta dissertação, empregam o termo em questão e seus correlatos (“didattizzare", "didattizzato", "didatticizzazione" etc), sem, contudo, explicar claramente o que eles significam.

Por isso, tendo em vista que a didatização é um conceito fundamental no trabalho que aqui se apresenta, foi-nos necessário, a partir da leitura das obras de tais autores, elaborar uma definição: para nós, o termo didatização designa o complexo processo de exploração do texto autêntico por meio de técnicas didáticas que visam torná-lo acessível e compreensível aos alunos, fazendo com que este seja realmente um instrumento de ensino-aprendizagem da língua-alvo.

\footnotetext{
${ }^{40} \mathrm{O}$ texto de Paola Begotti encontra-se disponível em: http://venus.unive.it/filim/materiali/accesso_gratuito/Filim_didattizzazione_analisi_teoria.pdf. Acesso em 25 de maio de 2012.

${ }^{41}$ No texto original: "Tra le competenze richieste ad un insegnante ritroviamo sicuramente la capacità di didattizzare materiali autentici per i propri studenti".
} 
A didatização não implica em alterações, adaptações ou simplificações promovidas no texto autêntico pelo professor, mas sim, na elaboração de atividades com base em tal texto. Tais atividades são criadas pelo docente a partir desse material, sem que o professor efetue modificações no texto em questão; isto é, o processo de didatização, a nosso ver, diz respeito à criação de atividades a partir de um material que apresenta input genuíno, e não um input alterado ou adaptado.

Com base na Teoria de Aquisição de Segunda Língua, de Krashen, e na Teoria da Aprendizagem Significativa, de Ausubel, podemos dizer que didatizar materiais autênticos constitui uma maneira de oferecer aos alunos input compreensível, o que poderá resultar na aprendizagem significativa da LE por parte deles. Assim, a didatização desse tipo de material consiste em um processo que permite tornar o texto autêntico acessível e compreensível aos discentes, a partir de atividades que vão ao encontro de suas necessidades e de seus interesses e que lhes permitam, portanto, apropriar-se desse texto trabalhado em sala de aula.

A apropriação do texto autêntico por parte do aprendiz consiste, segundo Widdowson (1978), no processo de compreensão do texto, bem como em sua reinterpretação e inserção no repertório de conhecimentos linguísticos e culturais que o aluno já possui, isto é, apropriar-se do texto significa compreendê-lo, integrá-lo aos próprios conhecimentos prévios e ampliá-los, de modo a construir novos conhecimentos a partir desse texto.

O processo de didatização do material autêntico requer, do professor de línguas estrangeiras que se propõe a realizá-lo, tempo, estudo e dedicação. São etapas essenciais desse processo: a escolha de um texto autêntico com base nas necessidades e interesses do grupo de alunos ao qual ele será destinado; a definição e a delimitação dos objetivos a serem atingidos a partir do trabalho com esse texto; a seleção e/ou elaboração de atividades que permitam explorar, ao máximo, o texto selecionado; a aplicação de tais atividades e a avaliação dessa aplicação.

Como dissemos anteriormente, a didatização envolve o conhecimento e a utilização de técnicas didáticas. Estas consistem em atividades que fazem referência a abordagens e métodos de ensino de LE e, se adequadamente escolhidas, elaboradas e aplicadas, as técnicas podem facilitar o processo de apropriação dos textos autênticos pelos estudantes.

As definições de abordagem e método já foram abordadas no capítulo 2 deste trabalho, por esse motivo, no presente capítulo, discorreremos apenas sobre as técnicas. $\mathrm{O}$ 
conhecimento de técnicas didáticas por parte do professor pode permitir-lhe explorar as potencialidades de cada texto, bem como ampliar e diversificar o repertório de atividades a serem oferecidas aos discentes, embora saibamos que é impossível ter um repertório completo das técnicas utilizáveis. De qualquer forma, conhecer diferentes técnicas e aplicá-las nas aulas pode contribuir para que estas sejam interessantes e não se tornem repetitivas e monótonas. A esse respeito, Mezzadri (2003, p. 100) ressalta que:

Se a motivação é fundamental para promover a aprendizagem, então faz-se necessário (...) estimular a curiosidade, da qual o prazer é um componente fundamental, através da variedade de atividades e de seu formato, evitando a monotonia causada por uma abordagem sempre igual a si mesma" (grifo do

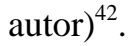

Desse modo, levando em conta a importância de que nós, professores de LE, conheçamos diferentes técnicas didáticas, trataremos, a seguir, do tema em questão.

\subsection{Algumas técnicas de didatização de materiais autênticos ${ }^{43}$}

Tendo em vista os postulados de Anthony (1963), Almeida Filho (1993), Balboni (1995) e Borneto (1998), segundo os quais, as técnicas dizem respeito ao nível das atividades realizadas na sala de aula, conhecê-las é um fator indispensável para podermos realizar o processo de didatização de materiais autênticos, com o intuito de utilizar essa categoria de texto em nossas aulas de LE.

Após selecionar um texto autêntico, o professor precisa elaborar, com base no material escolhido, atividades que atendam às necessidades e aos interesses discentes e que facilitem a apropriação do texto pelos alunos. Para tanto, de acordo com Danesi (1998), é fundamental que o professor disponha de um repertório amplo de técnicas didáticas, que lhe permitam ampliar, diversificar e enriquecer o próprio trabalho.

Obviamente, conhecer diferentes técnicas para didatizar materiais autênticos é um dos aspectos necessários para que o professor de LE possa diversificar suas práticas em sala de aula, mas não é o único: é importante que ele planeje suas aulas de modo a levar

\footnotetext{
42 No texto original: "Se la motivazione è fondamentale per promuovere l'apprendimento, allora risulta necessario (...) stimolare la curiosità, di cui il piacere è una componente fondamentale attraverso la varietà delle attività e del loro formato, evitando la monotonia causata da un approccio sempre uguale a se stesso".

${ }^{43}$ Parte das reflexões apresentadas em 3.2 foram retiradas de nosso artigo "Técnicas didáticas para a utilização de materiais autênticos na sala de aula de língua estrangeira", publicado no volume 4 da revista Serafino, um periódico dos alunos de Pós-Graduação do Programa de Língua, Literatura e Cultura Italianas da Faculdade de Filosofia, Letras e Ciências Humanas da Universidade de São Paulo.
} 
em conta as necessidades e interesses dos alunos e que possa, como afirma Kumaravadivelu (2006), saber como agir de forma autônoma, isto é, sem ficar preso a imposições de instituições, currículos e livros didáticos.

Esse teórico discorre sobre a importância de três parâmetros que, a seu ver, são fundamentais para que o docente possa realizar seu trabalho de maneira autônoma e crítico-reflexiva:

- o da particularidade - considerado o mais importante, por referir-se ao fato de que a pedagogia de línguas deve levar em conta as especificidades dos alunos, dos professores e de todos os aspectos envolvidos no processo de ensino-aprendizagem;

- o da praticidade - que se refere à necessidade de o professor elaborar teorias a partir de sua prática e praticar o que ele teoriza;

- o da possibilidade - parâmetro que se baseia nos postulados de Paulo Freire e diz respeito à necessidade de a pedagogia levar em consideração a identidade e as experiências dos aprendizes, visando-se a ações que tornem possíveis as transformações sociais.

Nesse sentido, a didatização de materiais autênticos representa uma mudança muito importante no âmbito metodológico, uma mudança que, segundo Kumaravadivelu, faz parte da Era Pós-Método: nesta, o professor não é mais considerado passivo (um profissional que simplesmente segue livros didáticos e programas propostos, quase sempre, por outras pessoas - diretor, coordenador etc), mas sim, um criador ativo de atividades.

Em tal perspectiva, o professor tem a autonomia de saber como atuar dentro dos limites acadêmicos e administrativos impostos pelas instituições, pelos currículos e pelos livros didáticos, desenvolvendo uma abordagem crítico-reflexiva sobre a sua própria prática de ensino, da qual faz parte a didatização de materiais autênticos que ele considere úteis no processo de ensino-aprendizagem da LE. Vejamos, a seguir, algumas das principais técnicas didáticas que nós, professores, podemos utilizar para desenvolver trabalhos com textos autênticos em nossas aulas de língua estrangeira.

\subsubsection{Técnicas didáticas para o desenvolvimento de habilidades e competências}

De acordo com Balboni (1999), um dos principais objetivos do processo de ensino-aprendizagem de uma língua estrangeira consiste no desenvolvimento de 
habilidades e competências na língua-alvo. As habilidades podem ser entendidas - afirma esse teórico - como um conjunto de processos e estratégias e como a capacidade de traduzir tais processos e estratégias em execução. As habilidades são de dois tipos:

- primárias - escutar, ler, falar e escrever. As duas primeiras são denominadas habilidades de compreensão/recepção e também podem ser chamadas, respectivamente, de habilidades de compreensão oral e de compreensão escrita. Já a terceira e a quarta denominam-se habilidades de produção e são chamadas, respectivamente, de produção oral e produção escrita;

- integradas ou secundárias - são aquelas em que se combinam duas ou mais habilidades primárias, tais como: dialogar, resumir, tomar notas, parafrasear, escrever mediante ditado, fazer traduções simultâneas etc.

As competências, por sua vez, englobam as diferentes habilidades. $\mathrm{O}$ conceito de competência, entretanto, é bastante controverso, tendo sido explicado e discutido por diversos teóricos, tais como: Chomsky (1965), Hymes (1972), Widdowson (1978), Canale e Swain (1980), Canale (1983). No presente trabalho, não temos a pretensão de discorrer sobre as diferentes concepções epistemológicas que envolvem as definições dadas ao termo em questão por esses teóricos.

Nosso objetivo consiste em tratar das diferentes técnicas que o professor de LE pode utilizar no processo de didatização de textos autênticos. Para atingir tal propósito, vejamos, a seguir, como Balboni e Mezzadri apresentam algumas técnicas, levando em conta, especialmente, o trabalho com habilidades e competências.

Balboni (1995), em seu livro Curricolo di italiano per stranieri, apresenta-nos uma compilação de técnicas didáticas, que mencionamos abaixo:

- técnicas para o desenvolvimento das habilidades de compreensão: associação língua/imagem, escuta plurilíngue, escuta seletiva, atividades com canções, cloze (exercícios de base teórica estruturalista), ditado, perguntas abertas (que admitem diferentes respostas), questões de tipo "sim/não" ou "verdadeiro/falso", questões de múltipla escolha, tabelas, monólogos, transcodificação (a forma mais típica de transcodificação é, segundo o autor, a escuta ou leitura de um texto e a execução de desenhos baseados nas informações contidas nele);

- técnicas para o desenvolvimento das habilidades de produção: atividades com canções, composição escrita, brainstorming (técnica que ativa os dois hemisférios do cérebro e na qual se listam ideias, embora de maneira não organizada), monólogo livre ou baseado em alguma proposta; 
- técnicas para o desenvolvimento das habilidades de interação e da competência sociopragmática: diálogo aberto (apresentam-se as falas de um personagem, e o estudante deve inserir as do outro personagem, levando em conta a coerência global do texto e a coesão com as falas anteriores e posteriores); diálogo em cadeia (o professor inicia um diálogo com uma pergunta; o aluno responde-a e faz a mesma pergunta a um colega, que deverá respondê-la e fazê-la a outro colega, e assim sucessivamente); dramatização; role play, role-making e role-taking (atividades de simulação); telefonema (atividade de simulação em que não há contato visual entre os alunos, o que os impede de utilizar gestos e expressões faciais e os faz ter a necessidade de verbalizar tudo);

- técnicas para o desenvolvimento das habilidades de "manipulação textual": contração de um texto (técnica que se refere à eliminação de frases ou sintagmas que não fornecem uma informação essencial ao objetivo do texto), ditado, paráfrase, resumo, anotações, tradução escrita, tradução simultânea, transformação de modalidade e de gênero (atividade em que se deve, por exemplo, passar do discurso direto ao indireto, de frase afirmativa a interrogativa; transformar um telefonema em uma carta, isto é, fazer com que um gênero textual torne-se outro), transcrição;

- técnicas para o desenvolvimento da competência linguística. Balboni subdivide essa competência em: fonológica, paralinguística, grafêmica, morfossintática, lexical, textual e extralinguística. Como principais exemplos de técnicas dessa categoria, ele cita estas: a exclusão (atividade em que os alunos devem descobrir o elemento que, em um conjunto de elementos linguísticos, não têm em comum com os outros o dado que os caracteriza; exemplo: uma palavra no singular em meio a um conjunto de palavras no plural); os jogos; a inclusão (técnica que requer dos estudantes a inclusão de elementos em um "todo caótico", isto é, em desordem); a caça ao erro; a seriação; os exercícios estruturais.

Outro teórico que também organizou uma compilação de técnicas em âmbito glotodidático foi Mezzadri (2003). O agrupamento proposto por Balboni assemelha-se ao organizado por Mezzadri: este, no entanto, divide as técnicas com base no desenvolvimento das habilidades primárias a serem trabalhadas no processo de ensinoaprendizagem de uma língua-alvo e com base no ensino da gramática e do léxico, enquanto aquele agrupa-as de acordo com as principais habilidades e competências a serem desenvolvidas nas aulas de LE. A seguir, apresentamos uma síntese das principais técnicas mencionadas pelo autor de I ferri del mestiere: 
- técnicas de escuta: visam ao desenvolvimento da habilidade de compreensão oral. Entre elas, podem-se citar: a associação (tarefa de agrupar/associar determinados dados inclusos no texto a imagens, palavras, definições, dados numéricos etc), as atividades de pré-escuta, a eliminação progressiva, a resolução de problemas, o preenchimento de espaços vazios (cloze), a escuta de canções, as perguntas fechadas, as tabelas, as questões abertas, a compreensão global (skimming), a compreensão detalhada (scanning);

- técnicas de leitura: seu objetivo central consiste no desenvolvimento da compreensão escrita. Nessa tipologia de técnicas, o autor cita: as atividades de pré-leitura, a reconstrução de textos, a transcodificação, o dar continuidade a um texto, as questões de múltipla escolha, os resumos, o skimming, o scanning etc;

- técnicas de produção oral: aquelas cujo objetivo principal consiste no desenvolvimento da expressão oral. Entre elas, destacam-se: a descrição de imagens; o diálogo; a dramatização; o role play; as discussões; a descrição de pessoas, objetos e lugares, entre outras;

- técnicas de produção escrita: visam ao desenvolvimento da expressão escrita; dentre elas, Mezzadri menciona as seguintes: o ditado, a composição, a associação, o cloze, a explicitação de conectivos, a interpretação de texto, entre outras;

- técnicas para o ensino da gramática: intentam favorecer a reflexão sobre a língua e a fixação de estruturas linguísticas. São exemplos desse tipo de técnica: o pattern drill (exercícios de repetição, substituição, transformação), as atividades lúdicas, a exclusão e inclusão, a criação de séries etc;

- técnicas para o ensino do léxico: aquelas através das quais se pretende desenvolver e ampliar o léxico, tais como: o spidergram (criação de esquemas em forma de teias), as associações lógicas, as associações palavras/imagens, as tabelas, o ditado, as traduções, a caça ao erro, a associação som/palavra, a associação de sinônimos e antônimos, a mímica.

Dentro dessas compilações de técnicas organizadas por Balboni e por Mezzadri, encontram-se atividades que remetem aos métodos tradicionais de ensino de línguas estrangeiras, tais como: os exercícios estruturais, que são técnicas muito usadas, sobretudo, no método audiolingual; o ditado e a tradução escrita, atividades empregadas, principalmente, no método gramática e tradução etc.

Encontram-se, também, técnicas que dizem respeito aos métodos alternativos de ensino de LE, entre as quais: a transcrição, atividade realizada frequentemente nas aulas 
baseadas no método comunitário; a utilização de canções (como vimos, a música tem um papel relevante na sugestopédia); as atividades de manipulação textual, empregadas, sobretudo, na segunda fase da aula sugestopédica; a mímica, técnica muito usada no método resposta física total; entre outras.

Além disso, entre as técnicas mencionadas por esses teóricos, também há algumas que fazem referência à abordagem comunicativa. Dentre elas, podemos citar: o diálogo em cadeia, a dramatização, o role play, os jogos etc.

Obviamente, não é sempre possível determinar, com clareza, a qual método e a qual abordagem pertencem cada técnica, pois algumas atividades são comuns a diferentes métodos e abordagens: o jogo, por exemplo, é uma atividade muito usada nas aulas embasadas pela abordagem comunicativa, mas também é uma técnica empregada nas aulas sugestopédicas. A respeito da dificuldade de determinar claramente a qual método/abordagem as técnicas remetem, Leffa ${ }^{44}$ (s. d, p. 28) salienta que

a teoria é importante na medida em que fornece o suporte teórico necessário para justificar cada atividade proposta, mas subjaz à atividade, podendo ou não ser explicitada. (...) A teoria trabalha nos bastidores; a prática é o que aparece no palco. Um bom trabalho de bastidores dá segurança ao que é apresentado, permitindo inovações e até ousadias (grifos nossos).

Assim, a nosso ver, mais importante do que determinar a qual método/abordagem remete uma determinada técnica, é ter clareza dos objetivos que pretendemos atingir junto aos nossos alunos em cada atividade proposta. Ou seja, não devemos escolher um tipo de atividade com vistas à execução de um método e de uma abordagem, mas sim, com o escopo de ir ao encontro dos interesses e necessidades de aprendizagem de nossos estudantes.

O agrupamento de técnicas proposto por Balboni, com base nas habilidades e competências a serem desenvolvidas no processo de ensino-aprendizagem da LE, constitui, a nosso ver, uma maneira de contemplar, de forma bastante abrangente e integrada, os principais objetivos a serem alcançados durante esse processo.

Por sua vez, a compilação de técnicas apresentada por Mezzadri, a qual se baseia no desenvolvimento das habilidades primárias e no ensino da gramática e do léxico, nos dá a impressão de que o autor considera que o desenvolvimento das habilidades de compreensão oral e escrita e de produção oral e escrita são independentes do estudo da

\footnotetext{
${ }^{44} \mathrm{O}$ texto de Vilson Leffa está disponível em http://www.leffa.pro.br/textos/trabalhos/prod_mat.pdf. Acesso em 21 de fevereiro de 2012.
} 
gramática e do léxico da língua-alvo, como se esses dois últimos fossem vistos como duas habilidades "a mais" a serem trabalhadas na sala de aula de LE.

A nosso ver, o desenvolvimento das quatro habilidades primárias é indissociável das reflexões sobre as estruturas linguísticas e da aquisição do léxico, isto é, à medida que o aluno desenvolve as habilidades primárias, também adquire a gramática e o léxico da língua-alvo e vice-versa; portanto, seria, talvez, mais adequado que as técnicas para o ensino da gramática e do léxico, propostas por Mezzadri, constassem das que fazem referência às quatro habilidades primárias.

\subsubsection{Técnicas didáticas sob uma perspectiva neurolinguística}

Assim como Mezzadri e Balboni, Danesi (1998) também agrupa e divide as principais técnicas didáticas. $\mathrm{O}$ autor de Il cervello in aula! propõe, numa perspectiva neurolinguística, a seguinte tipologia de técnicas didáticas:

- técnicas estruturais: são centradas no desenvolvimento da competência linguística e comunicativa, estando relacionadas à fluência verbal, que inclui a habilidade de utilizar e verificar tanto estruturas fonológicas, grafológicas, lexicais e morfossintáticas quanto estruturas comunicativas. De acordo com esse teórico, essas são as técnicas mais usadas em âmbito glotodidático, pois podem ser empregadas em qualquer fase do processo de ensino-aprendizagem de uma LE. Como exemplos de técnicas estruturais, Danesi cita: o ditado, o cloze, o dicto-composition (tipo de cloze em que os aprendizes devem completar as partes finais das frases ditadas e conferi-las somente ao final da atividade) etc;

- técnicas visuais: são aquelas que visam à utilização da relação entre imagem e expressão verbal. Tais técnicas valem-se do fato de que $80 \%$ das informações são percebidas pelo cérebro através da visão e implicam, portanto, em qualquer procedimento no qual se utilize a visualização para completar o desenvolvimento da produção oral. Dentre essas técnicas, estão a transcodificação ("tradução" de um texto oral ou escrito por meio de imagens) e as atividades nas quais se empregam fotografias, desenhos, filmes etc;

- técnicas lúdicas: baseiam-se no jogo linguístico, o qual permite uma maior integração sensorial, motora e motivacional que resulta no desenvolvimento da memória dinâmica e das representações simbólicas. Essas técnicas dividem-se em: jogos 
formais (exemplos: cruzadinhas, anagramas, etc), jogos de conteúdo (exemplos: resolução de problemas, adivinhas) e jogos comunicativos (exemplos: charadas, quiz, bingo, entre outros);

- técnicas humorísticas: colocam em destaque aspectos humorísticos e divertidos, favorecendo a compreensão global e o uso criativo da língua estrangeira. Entre elas, o autor menciona as atividades em que se empregam histórias em quadrinhos e piadas;

- técnicas de role play: implicam simulações dialógicas na sala de aula e requerem a participação criativa dos aprendizes nas atividades. A dramatização pode, segundo esse teórico, ser considerada um exemplo de role play.

Em sua compilação de técnicas, Danesi leva em consideração, sobretudo, aspectos neurolinguísticos. Conhecer alguns desses aspectos é muito relevante no momento de didatizar o material autêntico escolhido. Entre eles, podemos citar o fato de que a maior parte das informações chega a nosso cérebro por meio da visão. Isso significa que, ao selecionar e didatizar um material autêntico, a utilização de técnicas visuais é, em alguns momentos, imprescindível no processo de ensino-aprendizagem da LE.

Nas compilações organizadas por Balboni, Mezzadri e Danesi, encontramos, portanto, algumas das principais técnicas didáticas que o professor de LE pode utilizar para elaborar atividades baseadas em materiais autênticos, ou melhor, técnicas que auxiliarão o docente no processo de didatização desses materiais. Obviamente, conhecêlas não é suficiente para didatizar os textos, mas é já um passo inicial importante no trabalho pedagógico com os textos autênticos.

Para que esse trabalho seja eficaz, é importante que, além de conhecermos diferentes técnicas didáticas, saibamos escolhê-las, para didatizar os materiais autênticos adequadamente. Convém ressaltar que, como afirma Balboni, não há técnicas boas ou ruins, e que a escolha das técnicas constitui uma das etapas do processo de didatização.

Essa seleção pode ser feita com base em diferentes critérios, entre os quais merecem destaque: os objetivos que pretendemos atingir junto a nossos alunos em cada atividade, o nível de aprendizagem linguística em que eles se encontram, o gênero textual a que pertence o material escolhido (por exemplo, as atividades feitas a partir de um artigo de opinião serão, provavelmente, diferentes das que podem ser feitas com base em uma história em quadrinhos), as especificidades do texto selecionado.

Na presente dissertação, interessam-nos, sobretudo, as técnicas que podem ativar os conhecimentos prévios dos alunos, pois, conforme explicado no capítulo 1, os subsunçores são responsáveis, em grande parte, tanto pelo processo de aprendizagem 
significativa da LE quanto pelos interesses dos estudantes. Portanto, os conhecimentos prévios dos aprendizes devem ser levados em consideração no momento de elaborarmos as atividades com base no texto autêntico escolhido.

\subsubsection{As técnicas didáticas e a aprendizagem significativa da língua-alvo}

Para Ausubel, a aprendizagem significativa é um processo de aquisição de conhecimentos, no qual um conhecimento prévio especificamente relevante, existente na estrutura cognitiva do aprendiz, serve como ponto de apoio para o conhecimento a ser adquirido. A partir da interação entre esses dois tipos de conhecimento produz-se o novo conhecimento. Quando o conhecimento a ser adquirido não encontra um subsunçor no qual se apoiar, ocorre a aprendizagem mecânica que, a nosso ver, não constitui o objetivo do processo de ensino-aprendizagem de uma língua estrangeira.

Por isso, visando favorecer a aprendizagem significativa da LE por nossos alunos, é importante elaborarmos atividades em que sejam trabalhados os seus conhecimentos prévios, ou seja, sempre que possível, devemos utilizar técnicas didáticas que propiciem a ativação dos subsunçores dos discentes. Com base nas compilações de técnicas propostas por Balboni, Mezzadri e Danesi, comentamos, abaixo, algumas atividades que podem promover o trabalho com os conhecimentos prévios dos estudantes:

- Associação língua/imagem - são apresentados diversos textos autênticos visuais ${ }^{45}$ aos alunos (por exemplo, fotografias retiradas de revistas que circulam no país em que se fala a língua-alvo; pinturas feitas por artistas de tal país - no caso da Itália, por exemplo, pinturas de Leonardo da Vinci, Michelangelo, Caravaggio, De Chirico etc) e, em cada uma delas é colocada um numeral (ou uma letra). Os estudantes observam as imagens e, depois, leem ou escutam textos breves, que são numerados. Depois, os discentes devem associar cada imagem ao respectivo texto. Essa técnica pode ser usada para explorar tanto a compreensão global de um texto (compreender o sentido geral de uma descrição, por exemplo, e associá-la à imagem correspondente) quanto a compreensão detalhada (quando as imagens são parecidas uma com a outra e diferenciam-se apenas por pequenos detalhes). O uso de imagens permite a ativação

\footnotetext{
${ }^{45}$ Conforme mencionamos no capítulo 1, não nos ocuparemos, nesta dissertação, dos textos autênticos visuais (aqueles em que são usadas apenas imagens, como as fotos, as pinturas, as ilustrações etc); no entanto, convém ressaltar que esses textos podem ser muito úteis na realização da atividade de associação entre língua e imagem.
} 
do conhecimento de mundo dos alunos, que deverão esforçar-se por relacionar seus conhecimentos prévios não linguísticos aos conhecimentos a serem adquiridos na língua-alvo.

- Atividades com canções - antes de fazer os discentes escutarem a canção a ser trabalhada em sala de aula, o professor pode, por exemplo, dizer-lhes apenas o título dela e pedir-lhes que, a partir deste, façam inferências a respeito do conteúdo da canção. Segundo Koch (1997, p. 28),

as inferências constituem estratégias cognitivas extremamente poderosas, que permitem estabelecer a ponte entre o material linguístico presente na superfície textual e os conhecimentos prévios e/ou compartilhados dos parceiros da comunicação. Isto é, é em grande parte através das inferências que se pode (re)construir os sentidos que o texto implícita (grifo nosso).

- Atividades de pré-escuta - a técnica acima mencionada é um exemplo de atividade de pré-escuta. Como já dissemos, esse tipo de atividade pode acionar os conhecimentos prévios dos alunos, pois favorece a elaboração de inferências. O material autêntico a ser escutado pode ser não apenas a canção, mas também qualquer outro gênero textual oral (ou oral e visual), tais como: uma entrevista radiofônica ou televisiva, um filme, um diálogo etc. Podemos aplicar essa técnica, por exemplo, ao trabalho com transmissões radiofônicas, dizendo aos alunos somente o tema da transmissão a ser escutada e solicitando-lhes que infiram qual será o tratamento dado a este.

- Atividades de pré-leitura - da mesma forma que as atividades de pré-escuta, as técnicas de pré-leitura podem facilitar a aprendizagem significativa da LE por parte dos discentes, visto que elas possibilitam aos alunos a elaboração de inferências. O professor pode, por exemplo, solicitar que os estudantes infiram, com base no título, o conteúdo de um texto autêntico a ser lido na sala de aula. Para elaborá-las, eles terão de utilizar seus conhecimentos prévios de tipo linguístico e extralinguístico. O docente pode, também, mostrar aos aprendizes um texto e propor-lhes que, antes da leitura, identifiquem a que gênero textual pertence; nesse caso, os aprendizes deverão acionar seus conhecimentos prévios referentes aos diversos aspectos que caracterizam os variados gêneros de texto.

- Perguntas abertas - também chamadas de perguntas inferenciais, estas consistem em questões elaboradas a partir de um texto (preferencialmente, autêntico) e que admitem mais de uma resposta, que não é encontrada nele. Portanto, para elaborá-la, os alunos deverão refletir sobre o texto lido ou escutado e fazer inferências, procurando relacioná-lo às aquisições cognitivas de que eles já dispõem. 
- Spidergram - essa técnica pode ser utilizada em várias fases da aula e refere-se à criação de esquemas em forma de teia. No centro do esquema, é colocado, por exemplo, um hiperônimo (retirado de um texto autêntico trabalhado junto aos alunos) de um determinado campo semântico e, nas demais partes do esquema, são escritos os hipônimos de tal hiperônimo. Essa atividade favorece o funcionamento da memória, pois promove o agrupamento dos conhecimentos por categoria. Além disso, permite um tipo de sistematização do léxico que, segundo Mezzadri (2003), é muito mais eficaz do que listas de palavras. O spidergram é uma técnica que pode favorecer a aprendizagem significativa da LE, porque, nessa atividade, parte-se de um elemento mais abrangente para se chegar aos elementos mais específicos, isto é, essa atividade tem uma forma de organização que, numa perspectiva cognitivista, se assemelha à organização dos conhecimentos na mente do aprendiz. Nesta, a rede de conhecimentos constitui uma estrutura hierárquica, em cujo topo estão os aspectos mais abrangentes de um conteúdo e, subordinados a ele, encontram-se os elementos mais detalhados.

- Tabelas - consistem em técnicas muito úteis na fase de sistematização do léxico. $\mathrm{O}$ professor pode, por exemplo, preparar uma tabela com algumas palavras retiradas de um texto autêntico trabalhado com os alunos e solicitar-lhes que completem cada coluna da tabela com os sinônimos daquelas palavras, com os antônimos delas, com os hipônimos etc. Essa atividade exigirá, dos estudantes, que recuperem, em sua estrutura cognitiva, seus subsunçores de tipo linguístico, estabelecendo diferentes tipos de relações entre as palavras estudadas.

- Composição escrita - tradicionalmente, os aprendizes escrevem uma composição com base em um tema proposto pelo docente; contudo, Balboni (1995, p. 5) ressalta que “existem tantas formas de composição quantos são os gêneros textuais escritos ${ }^{46}$ ". Por isso, o professor pode propor a seus alunos um trabalho centrado em materiais autênticos de diferentes gêneros textuais. Ele poderia, por exemplo, propor aos discentes um trabalho baseado no gênero curriculum vitae $(\mathrm{CV})^{47}$, mostrando-lhes exemplos de CV retirados da internet; analisando, na sala de aula, tais exemplos; incentivando os estudantes a pesquisarem, em dicionários e em sites, as palavras necessárias para que possam elaborar, na língua-alvo, seus próprios curricula vitae; e,

\footnotetext{
${ }^{46}$ No texto original: “(...) esistono tante forme di composizione quanti sono i generi testuali scritti”.

${ }^{47}$ Em algumas de nossas aulas de italiano LE, ministradas para alunos do nível A2 (nomenclatura proposta pelo Quadro Comum Europeu de Referência para as Línguas), utilizamos o gênero curriculum vitae como base para a realização das atividades supracitadas; isto é, o exemplo acima mencionado foi retirado de nosso próprio trabalho didático-pedagógico com textos autênticos.
} 
por fim, orientando os alunos a escrevê-los. A técnica de composição escrita, nesses moldes, pode favorecer a aprendizagem significativa da LE por parte de nossos estudantes, ativando-lhes os conhecimentos prévios referentes aos aspectos e estratégias linguísticos, comunicativos e estilísticos que caracterizam os variados gêneros textuais escritos.

As técnicas descritas acima são apenas alguns exemplos de atividades que podem promover a aprendizagem significativa da LE por parte de nossos alunos. No capítulo 5 desta dissertação, mostraremos a aplicação concreta de algumas dessas técnicas na elaboração de atividades que construímos com base em materiais autênticos.

\subsection{Alguns conceitos da Linguística Textual importantes no processo de didatização de materiais autênticos}

Nossa pesquisa situa-se na área da pedagogia de línguas, que, como afirma Danesi (1998, p. 13), busca relacionar

as pesquisas sobre a aprendizagem das línguas àquilo que se deveria fazer praticamente na sala de aula de língua. É uma disciplina que se originou do trabalho da experiência didática diária, mas que reflete, ao mesmo tempo, as tendências mais avançadas em campo científico-educativo ${ }^{48}$.

Assim, por situar-se numa área interdisciplinar, nossa pesquisa embasa-se em teorias de ensino-aprendizagem em geral, em teorias de aquisição de línguas e em teorias linguísticas.

No presente capítulo, abordaremos uma teoria linguística que, ao lado da Teoria da Aprendizagem Significativa, de Ausubel, e da Teoria de Aquisição de Segunda Língua, de Krashen, apresentadas no primeiro capítulo, também nos oferece bases para este trabalho: a Linguística Textual (LT), um ramo da Linguística que começou a se desenvolver na década de 1960, na Europa e, em especial, na Alemanha.

De acordo com Fávero e Koch (2008, p. 11), a hipótese de trabalho da LT consiste em "tomar como objeto particular de investigação, não mais a palavra ou a frase, mas sim o texto, por serem os textos a forma específica de manifestação da linguagem".

\footnotetext{
${ }^{48}$ No original: “(...) le ricerche sull'apprendimento delle lingue a quello che si dovrebbe fare praticamente nell'aula di lingua. È una disciplina nata dal travaglio dell'esperienza didattica giornaliera, ma che riflette, allo stesso tempo, le tendenze più avanzate in campo scientifico-educativo".
} 
Segundo as autoras, a origem do termo Linguística Textual remonta a Cosériu, que o empregou, pela primeira vez, em 1955. Contudo, somente em 1966, com Weinrich, esse termo passou a ser utilizado com o sentido que possui hoje. Essa vertente da Linguística passou por diferentes momentos, inspirando-se em diversos modelos teóricos: inicialmente, sua preocupação consistia apenas em uma simples análise transfrástica; em seguida, tinha como objetivo a elaboração de gramáticas textuais; depois, passou a preocupar-se com o texto em si (que apresentava significados diversos para diferentes teóricos) e, atualmente, seu objeto de estudo consiste no texto, suas formas de processamento e todo o contexto que o envolve.

De acordo com essas autoras, nos primórdios dos estudos da LT, um dos grandes equívocos dessa corrente da Linguística foi ter considerado o texto como uma frase ampliada, quando, na verdade, este não consiste em uma simples sucessão de frases. Nos dias atuais, a LT, numa perspectiva sociointeracional de base cognitiva, postula que é impossível qualquer manifestação linguística fora do texto, uma vez que este consiste em uma manifestação da linguagem humana, envolvendo práticas sociais, históricas e culturais.

Tendo em vista esses diferentes momentos pelos quais passou a Linguística Textual, Marcuschi (2008, p. 74) nos lembra que "não se pode imaginar que haja apenas uma LT". Mas, para ele, esta pode ser considerada o estudo das operações linguísticas e cognitivas reguladoras e controladoras da produção, construção, funcionamento e recepção de textos escritos ou orais. Nessa perspectiva, pode-se dizer que a LT é uma vertente da Linguística que possui bases cognitivistas.

A esse respeito, o autor de Produção textual, análise de gêneros e compreensão esclarece que a língua não é um fenômeno apenas cognitivo, apesar de envolver atividades cognitivas. Ele explica que a língua consiste em atividades sócio-históricas, cognitivas e sociointerativas e que, sob essa ótica, o texto pode ser tido como uma entidade significativa, uma entidade de comunicação e um artefato sócio-histórico, que ativa estratégias, expectativas, conhecimentos linguísticos e não linguísticos. Assim, a visão defendida por tal teórico é a de uma LT de cunho sociocognitivista (MARCUSCHI, 2008, p. 60), e, em nosso trabalho, é esta Linguística Textual que nos dá subsídios para embasá-lo.

Essa teoria linguística está em consonância com a Teoria da Aprendizagem Significativa (de Ausubel) e com a Teoria de Aquisição de Segunda Língua (de Krashen), pois as três têm bases cognitivistas. Foi por esse motivo que, neste trabalho, optamos pela 
LT em questão, em detrimento de outras vertentes da Linguística, como a Análise do Discurso de linha francesa (AD) e a Análise Crítica do Discurso (ACD), embora saibamos que estas também têm contribuições inegáveis aos estudos textuais/discursivos.

Ainda quanto à visão de língua apresentada pela LT de base sociocognitivista, Marcuschi (2008, p. 60-61) ressalta que

a língua envolve atividades cognitivas, mas não é um fenômeno apenas cognitivo. Pois o paradoxo que surge quando se toma a língua como um fenômeno apenas cognitivo é o de não se conseguir explicar seu caráter social. (...) De qualquer modo, o cognitivismo que vamos aqui admitir é o defendido pela hipótese sociocognitivista, que não se confina na imanência do cérebro nem propõe a língua como um fenômeno biológico (restrito às sinapses cerebrais). Assim, a língua é vista como uma atividade, isto é, uma prática sociointerativa de base cognitiva e histórica. Podemos dizer, resumidamente, que a língua é um conjunto de práticas sociais e cognitivas historicamente situadas (grifos do autor).

Dentro dessa mesma perspectiva, o termo texto pode, segundo Fávero e Koch (2008, p. 26), ser considerado em duas acepções:

(...) texto, em sentido lato, designa toda e qualquer manifestação da capacidade textual do ser humano (quer se trate de um poema, quer de uma música, uma pintura, um filme, uma escultura etc), isto é, qualquer tipo de comunicação realizado através de um sistema de signos. Em se tratando da linguagem verbal, temos o discurso, atividade comunicativa de um falante, numa situação de comunicação dada, englobando o conjunto de enunciados produzidos pelo locutor (ou por este e seu interlocutor, no caso do diálogo) e o evento de sua enunciação. $\mathrm{O}$ discurso é manifestado, linguisticamente, por meio de textos (em sentido estrito). Neste sentido, o texto consiste em qualquer passagem, falada ou escrita, que forma um todo significativo (grifos das autoras).

No âmbito do ensino de línguas estrangeiras, ao considerarmos essas duas acepções de texto e, também, o fato de que eles são produzidos dentro de um determinado panorama sócio-histórico-cultural, podemos chamá-los de autênticos. No capítulo 1, discorremos sobre algumas das definições dadas ao termo texto autêntico e apresentamos a nossa própria definição para esse termo.

No presente capítulo, abordaremos alguns conceitos da Linguística Textual ${ }^{49}$ que são importantes em nossa pesquisa, tais como: texto (termo para o qual apresentamos, anteriormente, algumas definições), discurso, gênero textual, tipo textual e suporte. Todos esses conceitos são bastante complexos, por isso, em nossa dissertação, não temos, obviamente, a pretensão de esgotar o estudo deles; pretendemos apenas apresentar

\footnotetext{
${ }^{49}$ Esses conceitos não são objetos de estudo, exclusivamente, da Linguística Textual; há outras teorias que se ocupam deles, entre as quais, a Análise do Discurso de linha francesa e a Análise Crítica do Discurso. Mas, como explicamos anteriormente, neste trabalho, as definições que apresentaremos para tais conceitos são aquelas postuladas pela LT e, mais especificamente, pela LT de base sociocognitivista.
} 
algumas das definições possíveis para cada um destes. Tais definições ofereceram-nos subsídios para a elaboração do trabalho que aqui se apresenta.

\subsubsection{Texto e discurso}

Para tratar do conceito de texto, baseamo-nos em Koch (1997), Fávero e Koch (2008) e Marcuschi (2008), três grandes teóricos da Linguística Textual no Brasil. Sabese que, conforme a perspectiva teórica adotada, o mesmo objeto de estudo pode ser concebido de diferentes maneiras. $\mathrm{O}$ conceito de texto também se enquadra nessa regra, ou seja, apresenta diversos significados para diferentes teorias. Dentro da própria LT, esse conceito varia conforme o autor e a corrente teórica adotada. Em nosso trabalho, abordaremos apenas algumas concepções de texto propostas pela LT no decorrer do desenvolvimento dessa teoria linguística.

Segundo Koch (1997), em um primeiro momento, o texto foi concebido como uma unidade linguística superior à frase, uma sucessão ou combinação de frases e um complexo de proposições semânticas. Depois, passou a ser visto como uma sequência de atos de fala; decorrido algum tempo, passou a ser encarado como fenômeno primariamente psíquico, resultante de processos mentais; e, nos dias atuais, é, geralmente, visto como a forma específica de manifestação da linguagem, sendo esta entendida como atividade interindividual.

Sob a ótica da LT de caráter sociocognitivista, o texto é considerado uma unidade de sentido e de interação entre dois ou mais falantes, que mantêm algum tipo de relação entre si e visam a algum objetivo comum. Assim, todo texto é dialógico, implicando um $e u$ e um $t u$ que, juntos, constroem o sentido. Este consiste, segundo Marcuschi (2008, p. 74), no "efeito do funcionamento da língua, quando os falantes estão situados em contextos sócio-históricos e produzem textos em condições específicas”.

A comunicação linguística não se dá por meio de unidades isoladas, como fonemas, morfemas ou palavras e frases soltas, mas sim, por meio de unidades maiores, isto é, textos. Por isso, estes não são apenas artefatos linguísticos; são eventos que ocorrem na forma de linguagem inseridos em contextos comunicativos, o que faz com que eles representem a língua em funcionamento.

Assim, o texto é uma unidade funcional, que não se define por sua extensão: podemos ter desde um texto com uma única palavra até um texto em vários volumes, 
como uma enciclopédia. Como ressalta Marcuschi, a extensão física não interfere na noção de texto em si. Mas, o que é, então, que nos permite reconhecer um texto como tal?

A resposta a essa pergunta é bastante complexa e está concatenada à textualidade, ou seja, ao que faz com que um texto seja um texto, e não um aglomerado de frases. Pode-se dizer que esta, numa perspectiva sociocognitiva, consiste em um conjunto de condições que conduz cognitivamente à produção e construção de sentidos.

De forma geral, a textualidade não depende da correção ortográfica e sintática da língua (embora tais aspectos possam interferir nela), e sim, de sua condição de processabilidade cognitiva. Marcuschi esclarece que a condição essencial da textualidade consiste no domínio da língua. Para ilustrar esse postulado, ele dá o seguinte exemplo:

\footnotetext{
Se não domino determinada língua - por exemplo, o russo, e me encontro em território russo - e me defronto com textos em russo, eles não vão funcionar como textos para mim, pois não sei operar com eles. (...) Note-se que não nego que haja um texto, mas nego que ele opere como tal em condições de inacessibilidade (MARCUSCHI, 2008, p. 90).
}

A partir do exemplo dado por esse autor, podemos dizer que operar com textos é uma maneira de inserir-se em uma cultura e dominar uma língua. Isso mostra o quanto é importante que, nas aulas de língua estrangeira, nós, professores, usemos o texto como unidade básica de ensino-aprendizagem.

Esse teórico salienta, também, que os três grandes pilares da textualidade são: o produtor (falante/escritor), o receptor (ouvinte/leitor) e o texto (evento comunicativo). Levando em conta esses três pilares, é possível afirmar que o texto é uma proposta de sentido que só se completa com a participação de seu receptor.

Os textos articulam-se, normalmente, em três níveis: o linguístico, o social e o cognitivo (que se refere aos conhecimentos prévios e aos conhecimentos partilhados entre o produtor e o receptor do texto). Desse modo, torna-se evidente que a produção e a compreensão de textos não consistem numa simples codificação e decodificação linguísticas, mas sim, em um complexo processo de construção de sentidos.

Marcuschi afirma que, atualmente, embora não haja, entre diferentes correntes teóricas da Linguística, um consenso quanto à definição do termo texto, há, entre linguistas teóricos e aplicados o consenso de que o ensino de línguas (tanto da LM quanto da LE) deva dar-se por meio de textos.

Tal consenso deve-se, sobretudo, ao fato de que, a partir destes, pode-se trabalhar a língua em seu funcionamento autêntico, e não simulado. Esse é, a nosso ver, um motivo 
muito relevante, para utilizarmos, em nossas aulas de língua estrangeira, textos autênticos, em vez de textos elaborados ad hoc.

Outro conceito muito importante, nos estudos linguísticos, é o de discurso, que é, sob perspectivas epistemológicas diferentes, objeto de investigação tanto da LT quanto da $\mathrm{AD}$ e da ACD. Entretanto, como já dissemos, em nosso trabalho, mostraremos apenas definições dadas pela Linguística Textual ao termo em questão. Na verdade, as definições dadas por essas três teorias linguísticas se intercruzam.

Para a LT, o discurso seria a linguagem vinculada às suas condições de produção e os efeitos de sentido na sua circulação sociointerativa. Por essa razão, o discurso é considerado uma prática, e não um objeto empírico. Ele está relacionado ao uso interativo da língua. Atualmente, postula-se que não é interessante estabelecer distinções rígidas entre o texto e o discurso, porque há, entre ambos, um continuum e certo condicionamento mútuo ${ }^{50}$.

Outro conceito também relacionado ao de texto e ao de discurso é o de domínios discursivos. Estes consistem em práticas discursivas de uma cultura, as quais abrangem, não um gênero em particular, mas sim, um conjunto de gêneros textuais que lhe são próprios e configuram rotinas comunicativas institucionalizadas. No âmbito do discurso jornalístico, por exemplo, é possível identificar diversos gêneros textuais, como o editorial, a notícia, a reportagem, a crônica esportiva, a carta ao leitor, a enquete, a errata, a entrevista jornalística etc. Assim, podemos dizer que o conjunto desses gêneros constitui o domínio discursivo jornalístico.

Até aqui, tentamos esclarecer que os conceitos de texto e discurso não são dicotômicos, mas sim, complementares, no sentido de que não há texto sem discurso e vice-versa e, portanto, eles coexistem e são interdependentes. A seguir, trataremos de outros dois conceitos de grande relevância nos estudos linguísticos: os de gênero textual e tipo textual.

\subsubsection{Gênero textual e tipo textual ${ }^{51}$}

\footnotetext{
${ }^{50}$ Cf. MARCUSCHI, 2008, p. 81.

51 A noção de gênero tem sido muito discutida e não se tem chegado a um consenso no tocante a questões terminológicas e epistemológicas. Assim, há alguns teóricos que utilizam as denominações gênero textual e gênero de texto, e há outros que empregam os termos gênero discursivo e gênero do discurso. O mesmo ocorre com os termos tipo textual e tipo de texto, os quais alguns autores chamam de tipo discursivo e tipo de discurso. Em nosso trabalho, considerando o gênero como uma forma textual, optamos pelos termos gênero textual e tipo textual.
} 
O estudo dos gêneros textuais é bastante antigo: no Ocidente, sua observação sistemática iniciou-se com Platão. O termo gênero, na tradição ocidental, estava relacionado aos gêneros literários, a cujo estudo dedicaram-se Platão e Aristóteles e, posteriormente, Horácio e Quintiliano. Nos dias atuais, a noção de gênero não está mais ligada apenas à Literatura, mas a muitas outras áreas, como a Sociologia, a Antropologia, a Retórica e a Linguística. Em nossa pesquisa, interessa-nos a definição de gênero dada por esta última e, especialmente, a concepção de gênero para a Linguística Textual.

Em tal âmbito, o gênero textual é uma forma cultural e cognitiva de ação social, e não somente uma entidade linguística formalmente constituída. Assim, os gêneros são realizações linguísticas concretas, que se materializam em situações comunicativas.

Nesse sentido, trabalhar com gêneros textuais significa trabalhar com a língua em seu cotidiano nas mais variadas formas. Em cada gênero, há ações de ordem comunicativa com estratégias convencionais que visam atingir determinados propósitos. Em geral, cada gênero possui objetivos muito claros, e tal aspecto o determina e lhe dá uma esfera de circulação.

Tendo em vista que os gêneros são formas concretas de realização de um texto, podemos dizer que toda manifestação verbal ocorre sempre através de textos, e que cada texto se materializa em algum gênero. Isso quer dizer que os gêneros dizem respeito às práticas sociais e às atividades humanas.

Como eles possuem complexidade variável e são sócio-histórico-culturais, tornase difícil contá-los. Entretanto, Marcuschi (2008), retomando Bakhtin (1979), alerta-nos para o fato de que os gêneros são inúmeros, mas não infinitos.

O nome dado a cada gênero não é, certamente, uma invenção pessoal, e sim, uma denominação histórica, cultural e socialmente construída. Todavia, algumas vezes, não é fácil determinar o nome de certos gêneros, pois eles se interpenetram, para constituírem novos gêneros. Além disso, com o advento das novas tecnologias, surgem sempre novos gêneros textuais, o que também dificulta a determinação de nomes para eles. Apesar disso, o autor de Produção textual, análise de gêneros e compreensão explica-nos que

em geral, damos nomes aos gêneros usando um desses critérios: 1. forma estrutural (gráfico; rodapé, debate; poema); 2. propósito comunicativo (errata; endereço); 3. conteúdo (nota de compra; resumo de novela); 4. meio de transmissão (telefonema; telegrama; e-mail); 5. papéis dos interlocutores (exame oral; autorização); 6. contexto situacional (conversação espontânea; carta pessoal). Mas vários desses critérios podem atuar em conjunto (MARCUSCHI, 2008, p. 164). 
Esse autor também esclarece que, hoje, não há mais, por parte da maioria dos estudiosos, uma preocupação em classificar os gêneros e categorizá-los. Ele afirma que, atualmente, a tendência é explicar a constituição e circulação social dos gêneros textuais. Uma vez que estes estão relacionados às práticas sociais, podemos dizer que os gêneros são os textos que encontramos em nossa vida diária, tais como: o e-mail, a piada, a receita culinária, o telefonema, a lista de compras, o cardápio, a aula expositiva, a aula virtual, o sms (mensagem de celular), a bula de remédio, o bate-papo no computador, o edital de concurso, a história em quadrinhos, o folheto de supermercado, o poema, o anúncio publicitário, a conversação espontânea etc.

Sob a ótica da LT, há, basicamente, duas modalidades de gêneros textuais: oral e escrita. Elas não configuram uma oposição; encontram-se em um continuum na relação entre a fala e a escrita. Todavia, é difícil, às vezes, classificar um determinado gênero simplesmente como oral ou escrito, pois alguns gêneros são híbridos.

Diferentemente dos gêneros, que são inúmeros, os tipos textuais constituem um conjunto bastante restrito, agrupando, geralmente, apenas estas categorias: narração, argumentação, exposição, descrição e injunção ${ }^{52}$. Os tipos textuais definem-se pela natureza linguística de sua composição (aspectos sintáticos, lexicais, relações lógicas etc) e consistem, a rigor, em modos textuais que subjazem à organização interna do texto.

Em determinado texto, quando predominam certas sequências linguísticas, dizemos que aquele é um texto narrativo, argumentativo, expositivo, descritivo ou injuntivo. Mas, o mesmo texto pode conter diferentes tipos textuais; um texto argumentativo, por exemplo, pode conter sequências descritivas. Assim, os gêneros textuais são, em geral, heterogêneos quanto aos tipos, embora um tipo sempre predomine.

Da mesma maneira que há, entre o texto e o discurso, uma relação de interdependência, existe, entre o gênero e o tipo textual, uma relação de complementaridade: todo texto concretiza-se em um gênero, que, por sua vez, realiza sequências tipológicas. Portanto, o gênero textual e o tipo textual não são dicotômicos; eles são complementares e interdependentes.

\footnotetext{
${ }^{52}$ Marcuschi (2008) afirma que há autores que incluem, na categoria dos tipos textuais, o conversacional. Assim, para tais estudiosos, haveria seis tipos textuais: o narrativo, o argumentativo, o expositivo, o descritivo, o injuntivo e o conversacional. $\mathrm{O}$ autor de Produção textual, análise de gêneros e compreensão não considera que este último seja um tipo textual, pois não vê a conversação como um tipo, mas sim, como um gênero textual. Concordamos com os postulados desse teórico, por isso, em nosso trabalho, mencionamos apenas cinco tipos textuais.
} 


\subsubsection{Suporte}

O suporte consiste em uma superfície física ou virtual, com formato específico, a qual serve de base para fixar e mostrar o gênero materializado como texto. A função essencial do suporte é a de fixar o texto, com o intuito de torná-lo acessível para fins comunicativos. Para que um gênero circule na sociedade, ele precisa de um suporte; por isso, este é muito importante.

É imprescindível diferenciar suporte e gênero textual, entretanto, isso nem sempre é feito com precisão. A respeito da dificuldade de distinguir esses dois conceitos, Marcuschi (2008, p. 176) diz:

Eu mesmo, em trabalhos anteriores, havia identificado o outdoor como gênero, o que é feito por vários autores, mas hoje admito claramente que o outdoor é um suporte público para vários gêneros, com preferência para publicidades, anúncios, propagandas, comunicados, convites, declarações, editais. Não é qualquer gênero que aparece num outdoor, pois esse é um suporte para certos gêneros, preferencialmente na esfera discursiva comercial ou política (grifos do autor).

Ainda acerca de tal dificuldade, ele ressalta que, para alguns autores, a homepage e o site são gêneros, contudo, para outros teóricos, são suportes. O referido autor defende a ideia de que aquela seja um gênero (que pode, inclusive, conter uma série de outros gêneros), mas este, um suporte. Além disso, sob a ótica desse teórico, a internet também é um suporte que contém, praticamente, todos os gêneros possíveis.

Os suportes dividem-se em duas categorias: os convencionais e os incidentais. Os primeiros são aqueles produzidos com a finalidade de fixar e mostrar o gênero textual, tais como: o livro, o jornal, a revista, o encarte, a faixa, o outdoor e o quadro de avisos. Já os segundos consistem naqueles que podem trazer textos, mas, que, geralmente, não são destinados a esse fim. Como exemplos de suportes incidentais, podemos citar: a embalagem, os muros, a parada de ônibus, as camisetas etc.

No quinto capítulo de nossa dissertação, procuramos ilustrar esses conceitos a partir de textos autênticos selecionados para elaborar atividades que aplicamos em nossas aulas de italiano como língua estrangeira. Esclarecidos os conceitos que norteiam nosso trabalho, procuraremos estabelecer, a seguir, de forma mais nítida, algumas relações entre estes e os materiais autênticos.

\subsection{Textos autênticos, conceitos da Linguística Textual e didatização}


Diversos teóricos, entre os quais Danesi (1998), Mezzadri (2003), Spinelli (2003), Begotti (s. d.), Bonvino (2008) e Marcuschi (2008) postulam que o ensino de línguas deva ter o texto como base, visto que, como nos lembra a Linguística Textual, a comunicação se dá por meio de textos, e não de palavras e frases soltas. Por esse motivo, como explicamos no capítulo 1 desta dissertação, é fundamental que, nas aulas de LE, sempre que possível, o professor utilize textos autênticos.

Cada texto autêntico materializa-se em um gênero textual, que por sua vez, é fixado em um suporte. Para facilitar o estudo dos materiais autênticos e viabilizar, de maneira mais eficaz, a utilização desses materiais no processo de ensino-aprendizagem de línguas, alguns teóricos propõem agrupamentos ou classificações para os textos autênticos. Vejamos, abaixo, as compilações propostas por Begotti (s. d.), Spinelli (2003) e Marcuschi (2008).

Paola Begotti elege o suporte como critério para agrupar tais textos, apresentando a seguinte classificação para eles: material ${ }^{53} \mathrm{em}$ papel, material em vídeo, material em áudio e material multimídia. Begotti, baseando-se nessa divisão, aborda os tipos de material autêntico, apresentando-nos algumas reflexões interessantes sobre eles, as quais podem ser úteis no processo de didatização de textos autênticos.

Consideramos pertinente, no entanto, completar a classificação de Begotti, visto que um telejornal, por exemplo, pode ser visto como um material de áudio e vídeo ao mesmo tempo; uma canção que se baixe da internet pode ser considerada um material áudio e multimídia e, assim por diante.

Quanto ao material autêntico em papel, a autora afirma que esse é o mais empregado pelos professores de língua estrangeira, pois é econômico e simples de se utilizar. Nessa tipologia de material, a autora inclui os seguintes gêneros: publicidades de revistas e jornais, cartazes, artigos de jornal, mapas geográficos, receitas, histórias em quadrinhos, folhetos de supermercado, convites, entre outros.

No que se refere ao material autêntico em vídeo, a estudiosa explica que ele é, geralmente, muito utilizado nas aulas de língua estrangeira, porque o cinema e a televisão oferecem uma grande quantidade de materiais utilizáveis para fins didáticos. Esse tipo de material apresenta uma série de exemplos de língua (registros, dialetos, variedades regionais, estilos etc), de situações comunicativas e temáticas úteis à aprendizagem da língua. Com ele, é possível - salienta a autora - elaborar atividades didáticas interessantes

\footnotetext{
${ }^{53}$ Conforme explicamos no capítulo 1, em nossa dissertação, empregamos os termos material autêntico e texto
} autêntico como sinônimos. 
e bastante úteis: as imagens facilitam a compreensão da mensagem linguística por parte dos alunos, pois esta aparece vinculada a todas as expressões, à gestualidade e aos demais elementos extralinguísticos que caracterizam cada cultura.

No tocante ao material áudio, Begotti diz que ele não é suficientemente levado em consideração pelos professores, que, em geral, utilizam-no apenas em forma de canções. Nessa categoria de material, a autora inclui estes gêneros textuais: os programas de rádio, os telejornais, as publicidades radiofônicas, a música em fitas cassete ou em CDs etc.

Por fim, discorre sobre o material autêntico multimídia, incluindo em tal categoria todos os arquivos em vídeo, em áudio ou apenas escritos, que se podem baixar da internet, ou os que podem ser utilizados no computador e em outros aparelhos eletrônicos, como Ipod, MP3, câmeras fotográficas digitais e celulares de última geração.

Begotti ressalta que a internet é um suporte que oferece grande quantidade de material autêntico utilizável em âmbito glotodidático, mas que apresenta, também, algumas desvantagens, porque, muitas vezes, a informação não é selecionada, e os textos apresentam frequentemente erros de digitação, de ortografia, problemas de concordância e outros tipos de problema que podem interferir na compreensão do texto; além disso, a utilização dos materiais multimídia requer, do professor e do aluno, conhecimentos tecnológicos, sem os quais pode se instaurar uma grande desmotivação.

Outros estudiosos, como Barbara Spinelli (2003), classificam os materiais autênticos com base não só no suporte, como também na modalidade do gênero textual. Assim, para essa autora, esses materiais dividem-se em: materiais orais, materiais escritos, materiais em vídeo e materiais digitais.

O agrupamento proposto pela autora mistura dois critérios (suporte e modalidade) de tal forma, que, ao se fazer uma primeira leitura de seu texto, pode-se ter a impressão de que um texto oral ou escrito não possa ser, ao mesmo tempo, um material em vídeo ou digital. Apesar disso, assim como Begotti, Spinelli também apresenta reflexões interessantes quanto à utilização de diferentes textos autênticos nas aulas de LE. A seguir, mencionaremos algumas delas.

Essa autora afirma que o gênero publicidade (de rádio, de TV ou escrita) mostrase muito eficaz no processo de ensino-aprendizagem da língua estrangeira, podendo ser trabalhado até mesmo com os alunos dos níveis iniciais de estudo da língua-alvo. Como esse gênero caracteriza-se, em geral, por textos curtos e formatos específicos, ele é facilmente reconhecível pelos estudantes, que conseguem levantar hipóteses e fazer inferências a partir de tal gênero textual, mesmo tendo pouco conhecimento da LE, o que 
pode contribuir para o aumento da motivação deles. Essas observações aplicam-se, também, a outros gêneros, como o horóscopo e as previsões do tempo.

O uso de materiais autênticos em vídeo possibilita, segundo Spinelli (2003, p. 139), o trabalho didático-pedagógico por meio de análises interculturais, pois “o recurso a outros códigos, como o das imagens em movimento, oferece ao estudante a oportunidade de consultar uma espécie de dicionário visual do contexto sociocultural ${ }^{54 "}$ da língua-alvo.

A autora menciona, também, a vantagem da utilização de materiais digitais (vídeos interativos, $C D$ rom, internet etc, na classificação por ela proposta) nas aulas de língua estrangeira: "os recursos oferecidos pela internet (...) compensam a fugacidade anual dos materiais em papel, pois aqueles são sujeitos a uma atualização constante sobre a cultura contemporânea e sobre a vida cotidiana do país estrangeiro ${ }^{55 "}$ (2003, p. 140).

Marcuschi (2008) também agrupa os gêneros textuais com base em um critério específico: a modalidade. Esse autor não utiliza o termo material autêntico para referir-se a cada um dos textos de que ele trata, provavelmente porque ele discorre sobre a questão dos gêneros textuais sob uma perspectiva de ensino da língua materna (neste caso, a língua portuguesa), e a distinção entre texto autêntico e didático é, geralmente, reforçada no âmbito do ensino de línguas estrangeiras. Na área de ensino de LM, também menciona-se tal diferenciação, porém ela não é tão destacada como na didática de LE.

$\mathrm{O}$ agrupamento proposto por Marcuschi parece-nos mais adequado do que o apresentado por Spinelli: esta autora mescla dois critérios, isto é, o suporte e a modalidade; por sua vez, aquele estudioso usa apenas a modalidade como critério para agrupar os textos autênticos e deixa claro que, como a fala e a escrita não constituem uma dicotomia, e sim, um continuum, há gêneros que se situam entre as duas modalidades. A respeito desse aspecto, o autor afirma que:

\begin{abstract}
A tentativa de observar os gêneros na relação fala/escrita resultaria numa visão antidicotômica, ao sugerir que eles: são históricos e têm origem em práticas sociais; são sociocomunicativos e revelam práticas; estabilizam determinadas rotinas de realização; tendem a ter uma forma característica; nem tudo neles pode ser definido sob o aspecto formal; sua funcionalidade lhes dá maleabilidade e definição; são eventos com contrapartes tanto orais como escritas (2008, p. 191).
\end{abstract}

Além disso, ele ressalta que há gêneros textuais cujas características não nos permitem classificá-los simplesmente como orais ou escritos, pois tais gêneros, além de

\footnotetext{
${ }^{54}$ No texto original: “(...) il ricorso ad altri codici come quello delle immagini in movimento offre allo studente l'opportunità di consultare una sorta di dizionario visivo del contesto socio-culturale".

${ }^{55}$ No original: "Le risorse offerte dall'internet (...) compensano la fugacità annuale dei materiali cartacei, poiché sono soggette ad un aggiornamento costante sulla cultura contemporanea e sulla vita quotidiana del paese straniero".
} 
materializarem textos orais ou escritos, são acompanhados por imagens ou outros elementos extralinguísticos. Entre esses gêneros, podemos citar: a publicidade de TV, a história em quadrinhos, a charge, entre outros. Por esse motivo, Marcuschi salienta que, embora agrupe os gêneros de acordo com a modalidade, ele prefere não estabelecer classificações.

Assim como Begotti e Spinelli, Marcuschi também discorre sobre os textos autênticos provenientes das novas tecnologias, particularmente da mídia eletrônica (digital). Com o advento da internet, surgiram novos gêneros, como o e-mail, o bate-papo on line, a aula virtual, entre outros, e segundo esse teórico, o meio tecnológico em questão interfere na natureza dos gêneros produzidos. Quanto a isso, o autor, citando David Crystal $^{56}$ (2001), ressalta que

\begin{abstract}
a internet transmuta de maneira bastante radical gêneros existentes e desenvolve alguns realmente novos. Contudo, um fato é incontestável: a internet e todos os gêneros a ela ligados são eventos textuais fundamentalmente baseados na escrita. Na internet, a escrita continua essencial (MARCUSCHI, 2008, p. 199).
\end{abstract}

Tendo em vista as compilações propostas por esses três autores, podemos dizer que, não há, entre os diferentes teóricos, um consenso quanto aos critérios de agrupamento dos textos autênticos. No entanto, todos eles afirmam que, muito mais importante do que classificá-los ou agrupá-los, é considerá-los como valiosos instrumentos de ensino-aprendizagem de línguas (tanto materna como estrangeira), pois eles possibilitam o trabalho didático-pedagógico com a língua em seu funcionamento autêntico.

\title{
3.4.1. Os textos autênticos orais no ensino de LE
}

Para desenvolver um trabalho didático-pedagógico eficaz com nossos alunos, podemos utilizar diferentes textos autênticos orais e escritos. Como professores de língua estrangeira, as primeiras questões que devemos colocar a nós mesmos, para escolher adequadamente um texto autêntico, são, segundo Breen (1985), as seguintes: O conhecimento, a priori, o interesse e a curiosidade do aprendiz podem ser favorecidos com esse texto? Como esse conhecimento, interesse e curiosidade podem ser ativados por tal texto?

\footnotetext{
${ }^{56}$ CRYSTAL, D. Language and the internet. Cambridge: Cambridge University Press, 2001.
} 
Se a possibilidade de favorecer a construção de conhecimentos do aluno por meio do trabalho com o texto autêntico é um dos principais critérios que devemos levar em conta no momento de selecionar esse tipo de material, não devemos esquecer que existem, basicamente, três tipos de conhecimento aos quais devemos nos reportar: o conhecimento linguístico (referente à L1 dos alunos e/ou a outras línguas estrangeiras que eles saibam); o conhecimento de mundo; e o (re)conhecimento das características e estratégias estilísticas, linguísticas e comunicativas dos diversos gêneros textuais orais e escritos.

Observando atentamente nossos alunos e entendendo quais são as suas expectativas e necessidades com relação ao ensino e à aprendizagem da língua estrangeira, conseguiremos, possivelmente, prever quais materiais autênticos vão ao encontro de seus interesses e necessidades e atendem às suas expectativas. Assim, o processo de ensino-aprendizagem da LE, tendo como instrumentos os textos autênticos, poderá ser incrementado produtivamente.

Quanto à utilização de textos autênticos orais, Wilkins (1976) salienta as dificuldades de compreensão oral que um discente estrangeiro encontra quando entra em contato com um falante nativo. Embora alguns alunos expressem-se adequadamente na LE, muitas vezes, entendem com grande dificuldade o que um falante nativo lhes diz. $\mathrm{O}$ motivo dessa dificuldade de compreensão deve-se, provavelmente, à escassa familiaridade dos aprendizes com textos autênticos orais.

Marcuschi (2008) afirma que é necessário sensibilizar o aluno às diferenças entre a língua oral e a língua escrita, uma vez que esta não é uma simples representação daquela. Esse aspecto é muito importante para a seleção de textos autênticos orais e escritos para os vários níveis de estudo da língua-alvo.

Rings $(1986)^{57}$, citado por Spinelli (2003), propõe uma escala em que há cinco estágios do maior ao menor grau de autenticidade de um texto oral. Essa escala pode ser útil para nós, professores de LE, no momento de selecionarmos o material autêntico:

1. um texto oral genuinamente autêntico é o que se obtém, quando os falantes nativos não sabem que sua fala (diálogos, mensagens de secretária eletrônica, transmissões radiofônicas etc) está sendo gravada para fins didáticos;

\footnotetext{
${ }^{57}$ RINGS, L. "Authentic Language and Authentic Conversational Texts”. In: Foreign Language Annals, 19, ${ }^{\circ}$ 3. New York, 1986.
} 
2. menos autêntico pode ser considerado um texto oral em que apenas um dos participantes da comunicação (um diálogo, por exemplo) sabe que sua fala está sendo gravada;

3. ainda menos autêntica é a gravação de um role play, no qual dois ou mais interlocutores devem improvisar uma situação;

4. menos autêntico do que o estágio anterior, porém mais estruturado do que este, é o contexto em que os participantes de um role play têm papéis precisos;

5. o último estágio é aquele em que dois ou mais falantes recitam um texto escrito.

No primeiro estágio dessa escala, podem ocorrer também "erros" por parte dos falantes nativos, porque eles se expressam espontaneamente, sem dar atenção à estrutura da língua em si. Segundo Rings, esse elemento deve ser incluído no mais amplo conhecimento do estudante, visto que faz parte da fala não planejada e visto que nem sempre aquilo que pode ser considerado "errado" na língua escrita também é considerado incorreto na língua falada ${ }^{58}$.

Para escolher um texto autêntico (oral ou escrito), é fundamental levar em consideração os interesses e as necessidades de aprendizagem específicos de cada aluno ou de cada grupo, pois, somente assim, esse texto poderá ser realmente um instrumento de ensino-aprendizagem da língua-alvo.

\subsubsection{O ensino de línguas estrangeiras e os textos autênticos escritos}

Como é sabido, a escrita não representa a fala e ambas são modalidades de realização dos textos, que se materializam em diferentes gêneros textuais. Segundo Marcuschi (2008), parece haver, atualmente, mais gêneros textuais na escrita do que na fala. Ele afirma que tal fato explica-se pela diversidade de ações linguísticas que praticamos, diariamente, na modalidade escrita.

Há muitas diferenças entre a língua oral e a língua escrita, o que implica em diferenças entre os textos orais e escritos. Entre estas, Mezzadri (2003) cita as seguintes: o texto oral, geralmente, não dá ao falante a possibilidade de reelaborar a mensagem e pode caracterizar-se por redundâncias, pausas e hesitações; já o texto escrito, em geral, oferece, a quem o produz, a possibilidade de revê-lo, modificá-lo e reelaborá-lo. Tanto os

\footnotetext{
${ }^{58}$ Cf. SPINELLI, 2003, p. 143-144.
} 
textos escritos formais quanto os informais requerem, quase sempre, uma formulação mais precisa e atenta do que os textos orais de diferentes registros.

O uso do texto oral é, normalmente, simultâneo ao momento de sua criação; na produção do texto escrito, por sua vez, o autor, salvo raras exceções, tem a possibilidade constante de refletir sobre o que escreveu, voltar ao texto e modificá-lo.

O texto escrito tem um caráter de permanência, isto é, permite, ao leitor, retomar o texto, relê-lo e aprofundar sua leitura, para compreendê-lo melhor; já o texto oral não tem esse caráter. Geralmente, o texto escrito não apresenta as repetições e os usos pleonásticos da língua que são tão frequentes no texto oral. Este, muitas vezes, é acompanhado por elementos extralinguísticos, como os gestos; tal aspecto inexiste no texto escrito.

Mezzadri (2003, p. 178) menciona, também, uma diferença essencial entre a língua oral e a escrita: o modo como elas são aprendidas. A esse respeito, o autor diz que

Se a língua materna é adquirida através do oral desde os primeiros momentos de vida da criança e de modo informal, a língua escrita é objeto de um processo de aprendizagem formal anos após a aquisição da língua oral. Isso, normalmente, não ocorre quando se trata de uma língua estrangeira aprendida na idade adulta, em contexto escolar ${ }^{59}$.

Assim, atualmente, postula-se que, no processo de ensino-aprendizagem de uma LE, não se estude primeiro a língua oral e, depois, a escrita; postula-se que ambas as modalidades linguísticas sejam trabalhadas ao mesmo tempo. Por tal motivo, é fundamental que nós, professores de línguas estrangeiras (e também de língua materna), utilizemos diferentes gêneros textuais orais e escritos em nossas aulas. Vimos, acima, alguns elementos específicos que devem ser levados em consideração, no momento de se trabalhar com textos autênticos orais. Agora, vejamos algumas reflexões referentes, em especial, ao trabalho com os textos autênticos escritos, embora algumas delas também sejam aplicáveis aos materiais autênticos orais.

Com alunos de níveis intermediários e avançados, os sólidos conhecimentos linguísticos deles possibilitam-lhes a leitura de textos autênticos complexos. O problema coloca-se nos primeiros níveis de estudo da LE: ainda que os discentes apresentem um vasto conhecimento de mundo, o limite linguístico pode tornar-se uma barreira, ou seja, nos níveis iniciais, o risco de que os estudantes não compreendam o texto e tenham um sentimento de frustração e desmotivação decorrente dessa incompreensibilidade é alto.

\footnotetext{
${ }^{59}$ No texto original: "Se la lingua madre viene acquisita attraverso l'orale fin dai primi momenti di vita del bambino e in modo informale, la lingua scritta è oggetto di un processo di apprendimento formale anni dopo l'acquisizione della lingua orale. Ciò normalmente non avviene quando si tratta di una lingua straniera appresa in età adulta in contesto scolastico".
} 
Para utilizarmos, com alunos dos níveis iniciais, um texto autêntico complexo do ponto de vista lexical e gramatical, podemos propor-lhes, a partir de tal material, atividades que exijam do grupo apenas uma compreensão geral dos sentidos do texto. Outro fator que pode motivar alunos desses níveis é o grau de familiaridade e de previsibilidade dos conteúdos que determinados gêneros textuais escritos podem apresentar, como o horóscopo, o folheto de supermercado, o boletim de previsão do tempo, entre outros. Quanto maiores forem as possibilidades de conexão entre o texto e a esfera afetiva e cultural do discente, melhor será a qualidade de interpretação dos sentidos do texto.

No que concerne aos critérios de seleção de textos autênticos escritos (mas, também, de textos autênticos orais), podemos afirmar que tais critérios variam de acordo com os objetivos que pretendemos atingir junto a nossos alunos, e a definição desses objetivos precisa estar ligada aos interesses, necessidades e expectativas dos discentes, ao nível de estudo da língua em que os alunos se encontram, bem como ao tipo de curso (os objetivos de um curso de italiano instrumental, por exemplo, serão diferentes dos de um curso de cultura italiana).

Todos os gêneros textuais selecionados (poemas, anúncios, receitas culinárias, bilhetes, e-mails etc) devem apresentar conteúdos que envolvam a esfera afetiva e diferentes processos cognitivos do aprendiz, para que sejam suficientemente significativos para ele. 


\section{O PAPEL dOS MATERIAIS AUTÊNTICOS E DIDÁticos NO PROCESSO DE ENSINO-APRENDIZAGEM DO ITALIANO LE: O PONTO DE VISTA DOS ALUNOS}

No presente capítulo, nosso objetivo consiste em investigar o ponto de vista de nossos alunos quanto aos materiais autênticos e didáticos. Afinal, os estudantes são o centro do processo de ensino-aprendizagem e os destinatários de tais instrumentos.

Por isso, neste capítulo, mostraremos a análise de uma parte dos dados de uma pesquisa realizada junto aos aprendizes do Italiano no Campus (IC). Para complementála, mostraremos, também, uma brevíssima análise das respostas dos professores do IC a algumas questões referentes aos materiais usados nas aulas.

\subsection{O Italiano no Campus (IC)}

O IC é um curso de difusão cultural da Faculdade de Filosofia, Letras e Ciências Humanas da Universidade de São Paulo (FFLCH-USP); é dividido em oito níveis, tendo cada qual a duração de quarenta e cinco horas. Quando cursado na modalidade extensiva, cada nível dura um semestre; todavia, os três primeiros estágios do curso também são oferecidos na modalidade intensiva (curso de férias) e, nesse caso, as quarenta e cinco horas são distribuídas em três semanas.

Além desses oito níveis do curso de língua italiana, o IC também oferece cursos de cultura italiana, em que são tratados diversos temas: música, literatura, geografia, cinema, entre outros. Oferece, além disso, cursos de conversação.

O Italiano no Campus, atualmente, é estruturado com base no Quadro Comum Europeu de Referência para as Línguas, documento que apresenta orientações concernentes ao ensino e à aprendizagem das línguas europeias. Segundo esse documento, tal processo abrange seis níveis: A1, A2, B1, B2, C1 e C2.

No Quadro Comum, o primeiro nível é denominado nível de contato; o segundo, nível de sobrevivência; o terceiro, nível limiar; o quarto, nível de progresso; o quinto, nível de eficácia; e o sexto, nível de domínio da língua.

Fazendo uma equivalência entre a nomenclatura proposta pelo Quadro Comum e a do Italiano no Campus, temos o seguinte: os níveis I e II do IC correspondem ao nível 
A1; os níveis III e IV equivalem ao A2; os estágios V e VI são correspondentes ao B1; e os níveis VII e VIII, ao B2. Desse modo, no IC, não temos os níveis C1 e C2, que são considerados os estágios mais avançados de apropriação de uma língua estrangeira, segundo o documento.

O Italiano no Campus é aberto não apenas aos alunos da Universidade de São Paulo (USP), como também à comunidade externa, isto é, qualquer pessoa pode se inscrever no curso, independentemente de ter, ou não, vínculo com essa instituição de ensino. O único requisito para efetuar a matrícula no curso é a conclusão do ensino médio, ou seja, a idade mínima dos alunos que frequentam o IC é, geralmente, 18 anos, o que o caracteriza como um curso destinado a adultos.

As aulas do IC são ministradas por estudantes do Programa de Pós-Graduação em Língua, Literatura e Cultura Italianas da FFLCH-USP e, portanto, por mestrandos e doutorandos. Embora atuem como professores no Italiano no Campus, tais estudantes são considerados monitores, por não terem vínculo empregatício com essa instituição de ensino.

Os objetivos principais desse curso consistem em divulgar a língua e a cultura italianas, bem como propiciar aos alunos o desenvolvimento das habilidades de compreensão oral e escrita e de produção oral e escrita em italiano ${ }^{60}$.

Por serem ministradas por alunos-pesquisadores, as aulas do Italiano no Campus, muitas vezes, são objetos de estudo e investigação por parte desses pós-graduandos. É nesse contexto que se insere a pesquisa de que trataremos no presente capítulo, visto que de março de 2009 até abril de 2011, lecionamos no IC.

\subsection{A pesquisa realizada com os alunos do IC}

Para Breen (1985), os materiais são meros instrumentos dentro do processo de ensino-aprendizagem de uma LE. Já para os alunos, qual é o papel dos materiais nesse processo? Qual é a importância que os aprendizes atribuem aos materiais autênticos e didáticos? Como é a relação que os estudantes estabelecem com tais instrumentos dentro e fora da sala de aula? Esses são questionamentos que nos fazemos desde 2009, ano em

\footnotetext{
${ }^{60}$ Tais informações podem ser confirmadas no site do Serviço de Cultura e Extensão da FFLCH-USP, disponível em http://sce.fflch.usp.br/node/685. Acesso em 03 de maio de 2012.
} 
que iniciamos o curso de Mestrado. A realização de uma pesquisa com os discentes foi a maneira que encontramos para buscar respostas a tais indagações.

Com o objetivo geral de investigar qual é, segundo a percepção dos alunos, o papel dos materiais autênticos e didáticos no processo de ensino-aprendizagem de línguas estrangeiras (especificamente, do italiano LE), fizemos, durante todo o mês de agosto de 2011, uma pesquisa com os aprendizes de todos os níveis dos cursos extensivos do IC.

A pesquisa consiste em um questionário composto de dezenove perguntas ${ }^{61}$ (das quais dezessete são abertas e duas fechadas) e de um pequeno formulário de identificação dos estudantes. O objetivo desse formulário consiste em traçar um perfil do público atendido pelo Italiano no Campus. Tal perfil será apresentado mais adiante. A seguir, mostraremos os objetivos específicos de cada pergunta:

Tabela 1 - Objetivos de cada pergunta do questionário respondido pelos alunos do IC

\begin{tabular}{|c|l|}
\hline $\begin{array}{c}\text { Número da } \\
\text { questão }\end{array}$ & \multicolumn{1}{c|}{ Objetivos } \\
\hline 1 & Conhecer os motivos que levaram os alunos a querer aprender italiano. \\
\hline 2 & Saber quantos estudantes já foram à Itália. \\
\hline 3 & $\begin{array}{l}\text { Saber há quanto tempo os alunos têm contato com essa LE em contexto formal de } \\
\text { ensino-aprendizagem. } \\
\text { Identificar o nível do Italiano no Campus que eles cursam no semestre em que } \\
\text { aplicamos o questionário, visto que alguns discentes (poucos) não preencheram o } \\
\text { formulário inicial. }\end{array}$ \\
\hline 4 & $\begin{array}{l}\text { Identificar percepções e impressões (ou até estereótipos) que os aprendizes têm } \\
\text { quanto aos italianos e à Itália. }\end{array}$ \\
\hline 5 & $\begin{array}{l}\text { Conhecer as razões pelas quais os estudantes gostam (ou não) das aulas de língua } \\
\text { italiana. }\end{array}$ \\
\hline 6 & Identificar o(s) aspecto(s) de que eles mais gostam nessas aulas. \\
\hline 7 & $\begin{array}{l}\text { Identificar qual (quais) é (são) o(s) aspecto(s) das aulas dos quais os alunos não } \\
\text { gostam. }\end{array}$ \\
\hline
\end{tabular}

\footnotetext{
${ }^{61}$ Para ver o questionário completo, cf. apêndice A.
} 


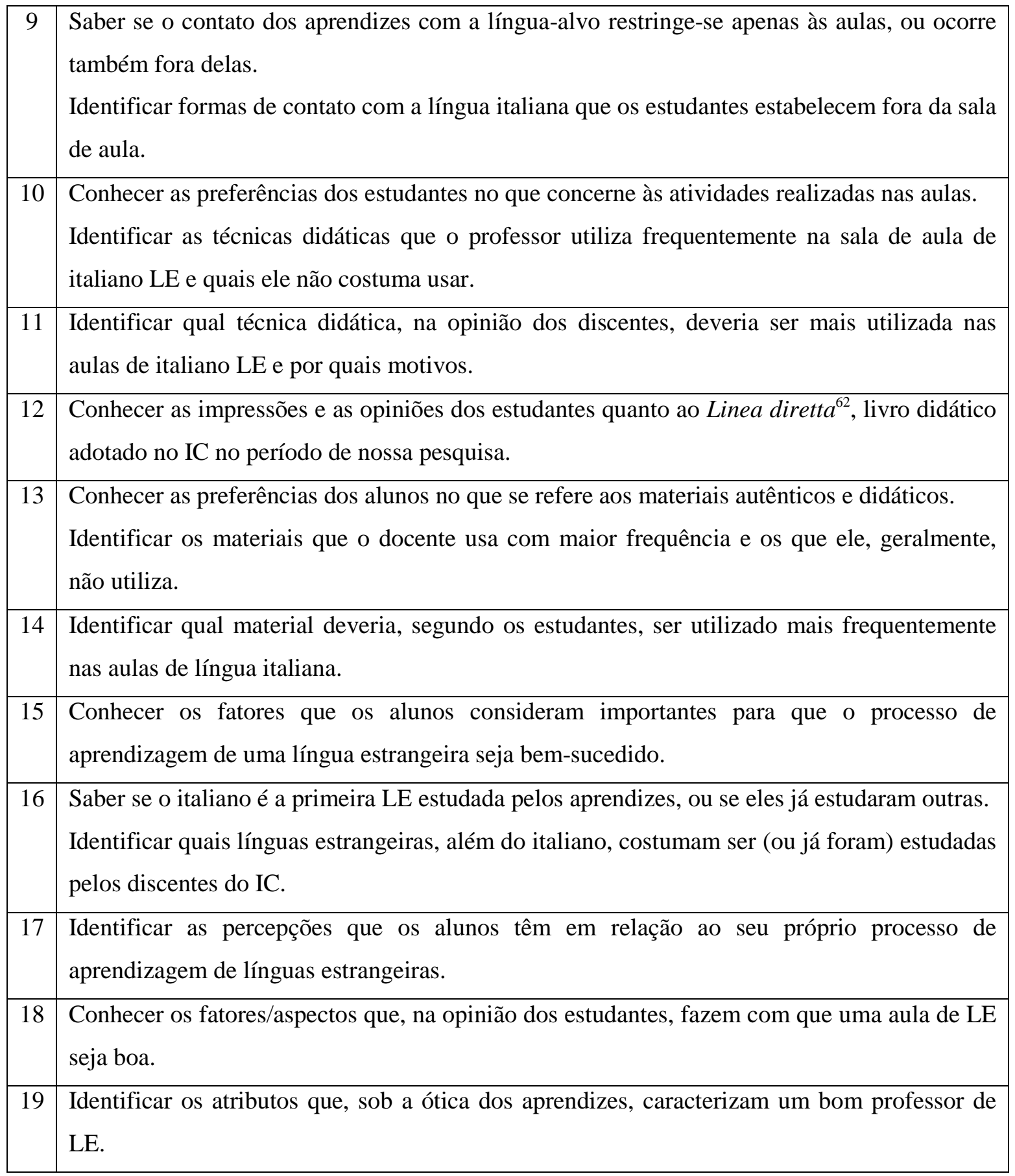

Gostaríamos de esclarecer que, na presente dissertação, mostraremos uma análise geral das repostas dadas pelos alunos à maioria das questões, mas, nos concentraremos, sobretudo, nas questões que se referem, direta ou indiretamente, aos materiais empregados nas aulas de italiano LE; isto é, apresentaremos uma análise detalhada somente das respostas às perguntas que nos auxiliaram a ter uma melhor compreensão do papel dos materiais empregados nas aulas de italiano LE, segundo a ótica dos discentes.

${ }^{62}$ No Italiano no Campus, são utilizados os livros Linea diretta 1a, 1b e 2. 
Portanto, as respostas concernentes às questões $1,2,3,5,6,7,8$ e 9 serão analisadas de forma geral; e as respostas às perguntas 10,11, 12, 13 e 14, de maneira detalhada. As respostas dos estudantes às demais questões serão objetos de análise em futuros trabalhos.

Aproveitamos a oportunidade de acesso aos alunos, para reunir, em um único instrumento de pesquisa, todas as questões que nos interessavam, inclusive para futuros trabalhos.

Tivemos de reunir todas as perguntas, porque, como é sabido, há diversos motivos que dificultam a aplicação de questionários na sala de aula, entre os quais: o fato de alguns alunos não gostarem de responder questionários; o problema de definir em que momento pedir aos estudantes para preenchê-los, sem atrapalhar muito o andamento das aulas; a dificuldade de convencer os aprendizes (e alguns professores) quanto à importância da pesquisa realizada etc.

Tendo em vista essas dificuldades, conversamos, pessoalmente, com todos os professores/monitores do IC e fizemos um acordo com eles, para podermos aplicar o questionário em todas as turmas. No total, eram vinte e oito turmas; algumas bastante numerosas, com vinte e cinco alunos; outras, com menos de dez estudantes.

Segundo informação do Serviço de Cultura e Extensão da FFLCH-USP (órgão responsável pelas matrículas dos interessados nos cursos do IC), trezentas e setenta e sete pessoas inscreveram-se nos cursos regulares do Italiano no Campus no segundo semestre de 2011. No entanto, nas datas em que realizamos a pesquisa junto aos alunos, alguns destes faltaram às aulas, por isso, não conseguimos fazê-la com todos os discentes, mas apenas com duzentos e noventa e quatro.

Comparecemos à maioria das turmas, por isso pudemos aplicar o questionário pessoalmente, o que foi muito positivo, pois pudemos explicar aos aprendizes os objetivos de nossa pesquisa e falar-lhes sobre a nossa dissertação de mestrado. Alguns estudantes foram muito solícitos e até se dispuseram a participar de entrevistas, caso se fizesse necessário. Outros, porém, mostraram-se um pouco resistentes em responder as questões; mas, por fim, todos acabaram colaborando conosco, isto é, todos os alunos presentes responderam o questionário que elaboramos.

Todavia, houve algumas turmas com as quais não pudemos conversar pessoalmente, visto que suas aulas eram em horários em que não poderíamos ir à FFLCH- 
USP. Por esse motivo, escrevemos uma carta ${ }^{63}$ para essas turmas, explicando-lhes, brevemente, o objetivo geral da pesquisa e solicitando-lhes que respondessem todas as perguntas. Assim, aplicamos, pessoalmente, o questionário em dezesseis das vinte e oito turmas. Para aplicá-lo nos demais grupos, contamos com a valiosa colaboração de nossos colegas que, em sua maioria, foram bastante atenciosos e prestativos.

Mais adiante, apresentaremos os dados da pesquisa os quais se referem, especificamente, aos materiais e faremos uma análise de tais dados, procurando interpretar as respostas dos alunos à luz dos postulados teóricos em que nos baseamos para fazer este trabalho. A seguir, apresentaremos uma caracterização do público atendido pelo Italiano no Campus no segundo semestre de 2011.

\subsubsection{O perfil dos aprendizes do Italiano no Campus}

O formulário de identificação dos alunos consiste em uma espécie de cabeçalho da pesquisa realizada junto aos discentes e apresenta os seguintes itens: nome (opcional), gênero, idade, grau de escolaridade, área de formação, profissão e nível do IC cursado no semestre em questão.

No tocante ao gênero, o público atendido pelo Italiano no Campus, no segundo semestre de 2011, era predominantemente feminino. Aliás, pelo que pudemos observar durante o período em que lecionamos no IC, geralmente, as turmas são constituídas, em sua maioria, por mulheres.

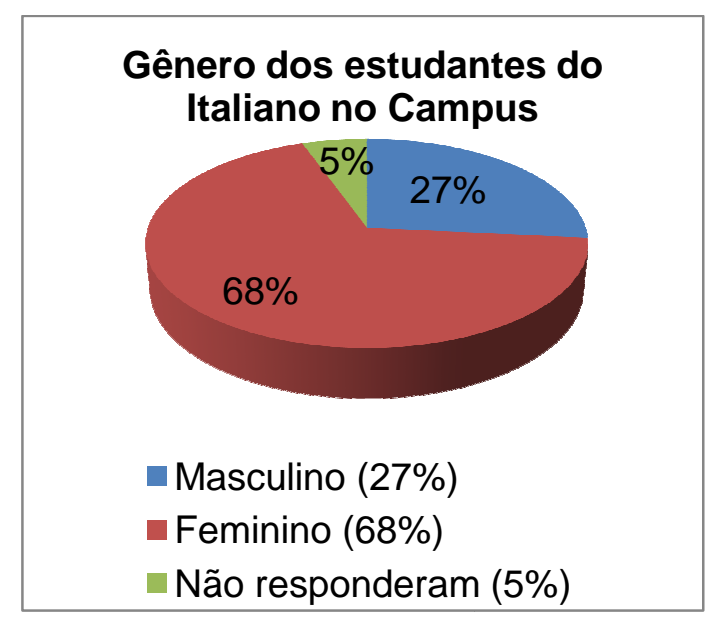

Gráfico 1 - Gênero dos alunos do IC

\footnotetext{
${ }^{63}$ A carta que escrevemos para os alunos do IC e a que escrevemos aos nossos colegas (professores/ monitores do IC) encontram-se ao final desta dissertação: respectivamente, apêndices B e C.
} 
Quanto à idade dos discentes, o único requisito necessário para realizar inscrição no IC diz respeito à conclusão do ensino médio; ademais, não há limite de idade para fazer matrícula no curso, razão pela qual temos, no Italiano no Campus, alunos de diversas faixas etárias. Assim, para organizar os dados referentes a esse item, agrupamos as idades dos estudantes, como se pode ver neste gráfico:

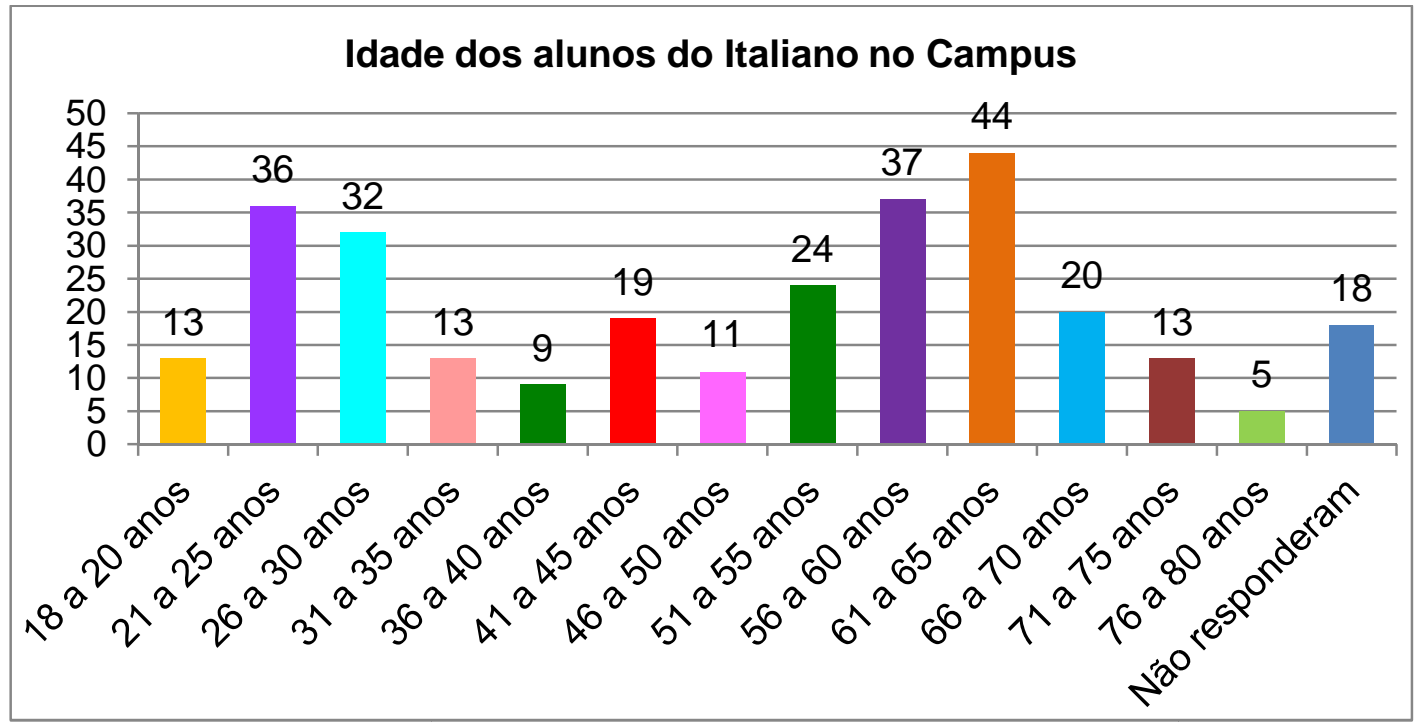

Gráfico 2 - Idade dos estudantes do IC

O gráfico acima permite-nos afirmar que oitenta e dois alunos têm mais de 60 anos, e apenas treze têm entre 18 e 20 anos, o que evidencia a presença de grande quantidade de aprendizes da terceira idade, bem como a presença de poucos estudantes que concluíram o ensino médio recentemente. Isso mostra o quanto as turmas do IC são heterogêneas com relação à idade.

No que concerne ao grau de escolaridade, temos, no Italiano no Campus, um público composto, predominantemente, por graduados, como ilustrado a seguir:

- Ensino Médio (5\%)

\section{Grau de escolaridade dos alunos do Italiano no Campus}

- Graduação em andamento (11\%)

- Pós-graduação concluída (14\%)

- Não responderam (5\%) 
Gráfico 3 - Nível de escolaridade dos discentes do IC

Como se pode notar, nossos alunos têm, em sua maioria, um nível alto de instrução formal. Tendo em vista que a maior parte dos discentes é graduada, vejamos quais são as suas áreas de formação.

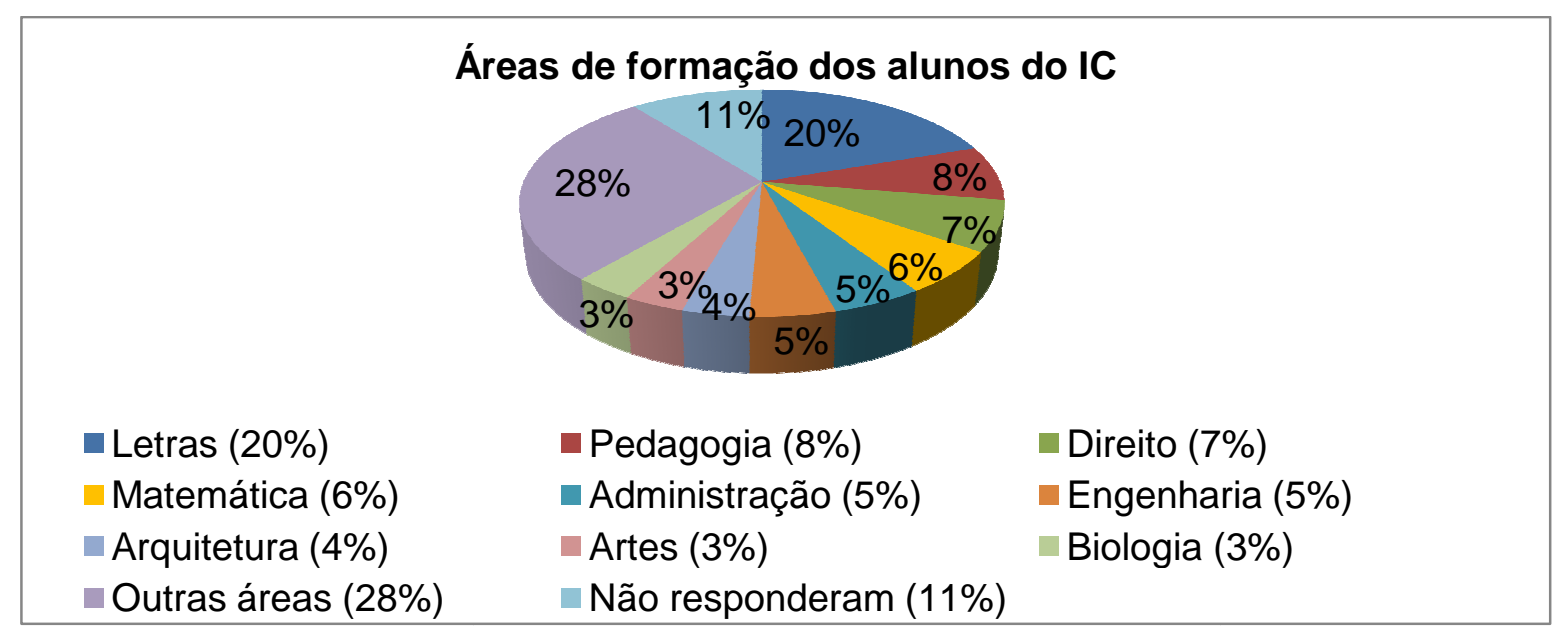

Gráfico 4 - Áreas de formação dos aprendizes do IC

No item "outras áreas", agrupamos os $28 \%$ de aprendizes que são graduados em outros âmbitos, a saber: Farmácia, Biblioteconomia, Ciências Contábeis, Moda, Filosofia, Turismo, Ciências Sociais, Publicidade, Medicina Veterinária, Agropecuária, Geologia, Comércio Exterior, Odontologia, Nutrição, Marketing, Terapia Ocupacional, Medicina, Tradução, Economia, Serviço Social, História, Psicologia, entre outros; há apenas de um a seis alunos formados em cada um desses âmbitos.

É interessante notar que alguns estudantes (22\%) afirmaram ter formação em mais de uma área; assim, por exemplo, temos, no Italiano no Campus, aprendizes formados em Letras e Direito, Matemática e Pedagogia, Letras e Arquitetura, Filosofia e Psicologia etc. Como se vê, no tocante às áreas de formação, as turmas do IC também são muito heterogêneas. Agora, vejamos quais são as profissões desses alunos. 
- Professores $(25 \%)$

- Engenheiros (4\%)

- Tradutores (2\%)

- Não responderam (9\%)

\section{Profissões dos alunos do IC}

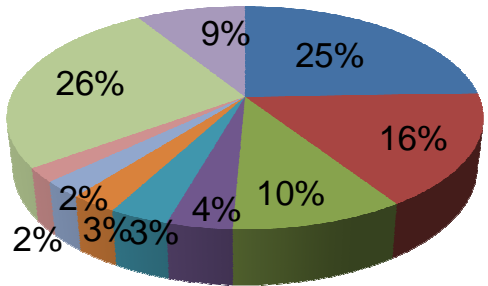

- Aposentados (16\%)

Estudantes (10\%)

- Advogados (3\%)

Administradores (3\%)

$\square$ Jornalistas $(2 \%)$

Gráfico 5 - Profissões dos alunos do Italiano no Campus

No formulário, alguns estudantes (32\%) indicaram sua profissão, mas escreveram que são aposentados; outros (16\%) não especificaram sua profissão e apenas disseram ser aposentados. Além disso, como alguns alunos possuem formação em mais de um âmbito, eles indicaram ter mais de uma profissão.

Como se vê no gráfico 5, muitos de nossos discentes são professores. Alguns deles (8\%) especificaram as disciplinas que lecionam, tais como: português, matemática, educação física, química etc. Outros $(6 \%)$ discriminaram o nível no qual atuam como docentes: educação infantil, ensino fundamental, ensino médio, ensino superior. E outros (11\%) escreveram, simplesmente, "professor".

As outras profissões mencionadas pelos alunos foram: arquiteto, assistente social, analista de negócios, secretário, empresário, corretor de imóveis, dentista, biólogo, músico, tapeceiro, geólogo, médico, oficial de justiça, enfermeiro, publicitário, revisor de textos, entre outras. Há apenas de um a seis estudantes, no IC, que têm essas profissões, por esse motivo resolvemos agrupá-las.

O último item do formulário está diretamente ligado à pergunta $n^{\mathbf{o}} 3$ do questionário, uma vez que o nível do Italiano no Campus cursado pelos aprendizes no segundo semestre de 2011 permite-nos deduzir há quanto tempo eles estudam, em aulas, a língua italiana. 


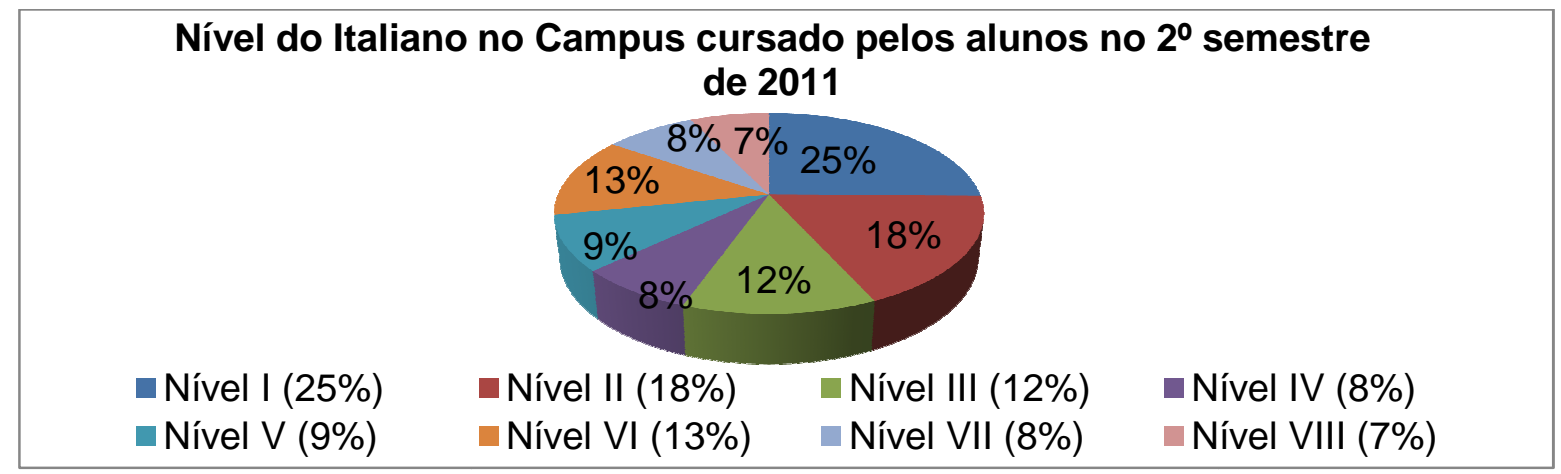

Gráfico 6 - Nível do Italiano no Campus cursado pelos aprendizes

A partir da leitura do gráfico e tendo em vista que essa pesquisa foi feita com os alunos em agosto de 2011, podemos dizer que os alunos iniciantes (25\%) estudavam italiano há menos de um mês, e os discentes que estavam no último nível do curso (7\%) estudavam-no há pouco menos de três anos e sete meses.

Observando o gráfico 6, é possível ter noção de que, no primeiro nível do curso, o número de matrículas é bem maior do que nos estágios subsequentes. Talvez, isso se deva ao fato de que alguns alunos querem apenas ter um nível básico de conhecimento da língua italiana; ou ao fato de que à medida que aumenta o grau de dificuldade e complexidade do estudo dessa LE, alguns discentes optam por não chegar aos níveis finais do curso.

Desse modo, a análise dos formulários de identificação dos aprendizes, permitenos caracterizá-los como um grupo composto predominantemente por mulheres (68\%), das quais uma parte significativa tem 56 anos ou mais. Além disso, podemos dizer que, quanto à idade, às áreas de formação e às profissões, a heterogeneidade é uma característica bastante evidente no IC. Por fim, podemos afirmar, também, que as turmas que costumam ter maior número de alunos são as dos níveis iniciais.

\subsubsection{Motivos pelos quais os alunos querem estudar italiano}

Após terem preenchido o formulário de identificação, os estudantes responderam as dezenove questões já mencionadas. A primeira delas diz respeito às razões que levaram os alunos a optar por estudar a língua italiana. As respostas evidenciam que os motivos são vários; abaixo, citamos todos os motivos e o percentual de alunos que mencionou cada um eles: 
- o gosto pela língua-alvo - 33\% dos discentes;

- a ascendência italiana $-27 \%$;

- o interesse pela cultura-alvo $-11 \%$;

- o interesse em conhecer a Itália (turismo) - 10\%;

- o gosto por línguas em geral - 7\%;

- o ingresso na pós-graduação (realização de exame de proficiência em italiano) - 7\%;

- o interesse em estudar na Itália - 5\%.

Alguns desses motivos podem ser sintetizados na resposta de uma aluna de 31 anos do nível II do IC: “[Optei por estudar italiano] Porque acho uma língua linda, tenho ascendência italiana, simpatizo com a cultura e queria falar outro idioma estrangeiro além do inglês ${ }^{64 \%}$. Muitos outros estudantes $(32 \%)$ mencionaram mais de uma razão que os levou a querer estudar a língua italiana.

\subsubsection{A quantidade de alunos que já foi à Itália}

As respostas dadas pelos alunos à questão "Você já foi à Itália?" reforçaram a ideia que defendemos no primeiro capítulo desta dissertação: a de que a utilização de materiais autênticos, nas aulas de italiano LE, pode ser bastante profícua e vantajosa em realidades como a brasileira, isto é, a realidade de um país distante da Itália e no qual alguns alunos não têm (ou não tiveram ainda) possibilidade de visitá-la. É o que se vê no gráfico seguinte:

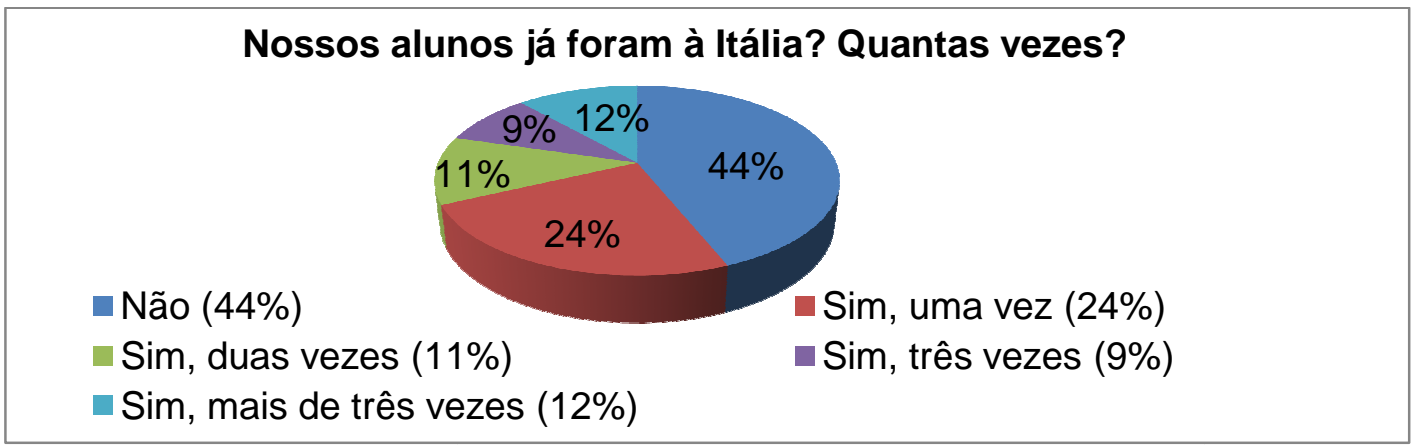

Gráfico 7 - Os estudantes do IC já foram à Itália?

64 Ao longo do presente capítulo, citaremos algumas respostas dadas pelos alunos. Para tanto, faremos transcrições literais, ou seja, transcreveremos as respostas exatamente como os aprendizes as escreveram; portanto, não faremos nenhum tipo de correção. 
Com base nesse gráfico, podemos afirmar que quase metade dos aprendizes do Italiano no Campus jamais esteve na Itália, ou seja, dos duzentos e noventa e quatro alunos que responderam nosso questionário, cento e vinte e nove não tiveram, ainda, a oportunidade de ter uma "imersão" no país cuja língua eles estudam. Aliás, muitos deles (29\%), em vez de responder apenas "não" a essa questão, responderam "infelizmente, não" ou "infelizmente, nunca fui à Itália". Nessas respostas, é clara a vontade que eles têm de ir ao país do qual estudam a língua.

Se tantos alunos ainda não puderam ir lá, o que nós, professores de italiano LE, podemos fazer para trazer um pouco da Itália para dentro da sala de aula? A resposta a essa questão está relacionada, a nosso ver, à utilização de materiais autênticos: tendo em vista que muitos de nossos estudantes nunca foram a tal país, fazer uso desses materiais, nas aulas de italiano LE, pode ser uma forma de reduzir a distância entre a sala de aula e a Itália, oferecendo aos aprendizes a possibilidade de ouvir e/ou ler textos que circulam no universo sociocultural dos italianos e de apropriar-se desses textos.

Pouco mais da metade dos alunos (56\%) já foi à Itália, porém boa parte deles (24\%) esteve lá apenas uma vez; isto é, tais discentes tiveram, provavelmente uma única vez, acesso constante ao que Brown e Menasche chamam de input genuíno.

Pensando, especificamente, nos alunos que já estiveram na Itália, vejamos o que eles responderam, quando lhes foi perguntado por quanto tempo eles ficaram lá.

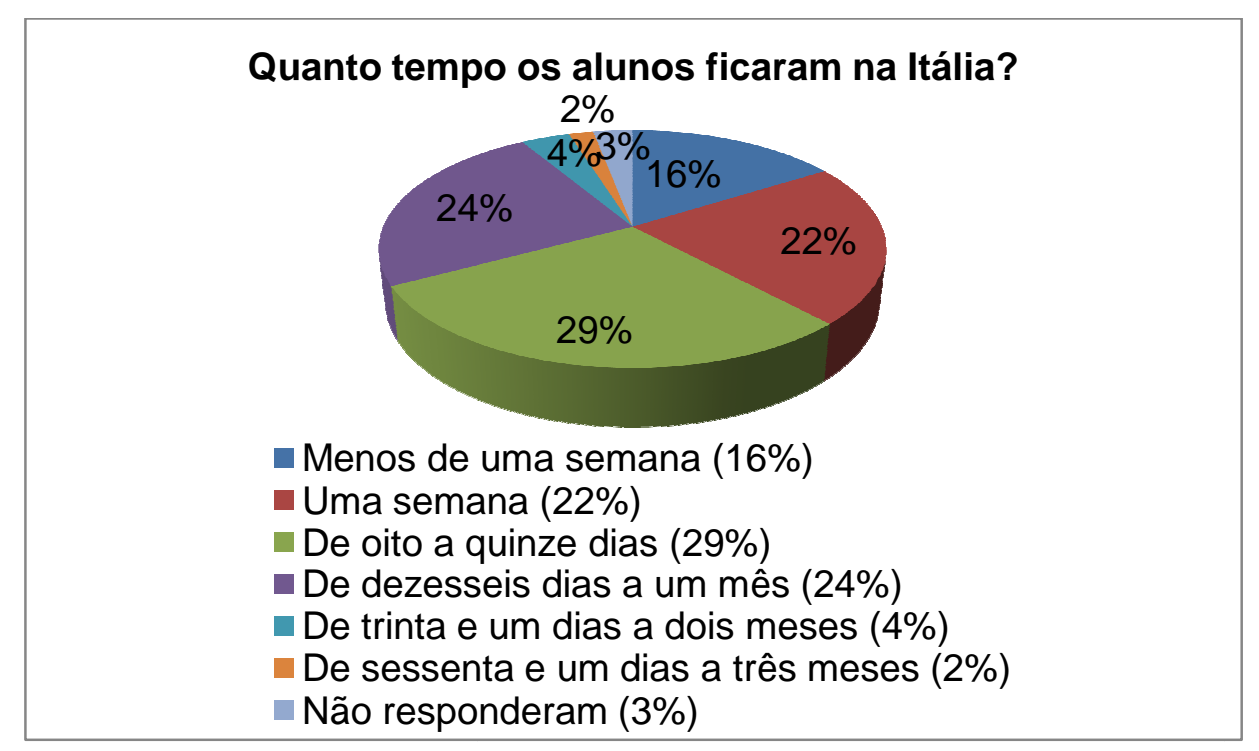

Gráfico 8 - Quanto tempo os estudantes do IC que já foram à Itália ficaram lá?

Vê-se, pelo gráfico, que dos cento e sessenta e cinco alunos que já estiveram no país em questão, a maioria permaneceu lá por um período de oito a quinze dias; apenas 
6\% dos aprendizes tiveram uma permanência, na Itália, superior a um mês. Alguns alunos que já foram à Itália mais de uma vez especificaram quanto tempo ficaram lá em cada uma das vezes; no entanto, apenas 5\% desses estudantes fizeram tal especificação.

\subsubsection{Razões pelas quais os aprendizes do IC gostam das aulas de italiano}

As respostas à questão 5 foram quase unânimes, isto é, praticamente todos os alunos do IC afirmaram gostar das aulas de italiano, como é possível notar no gráfico que segue:

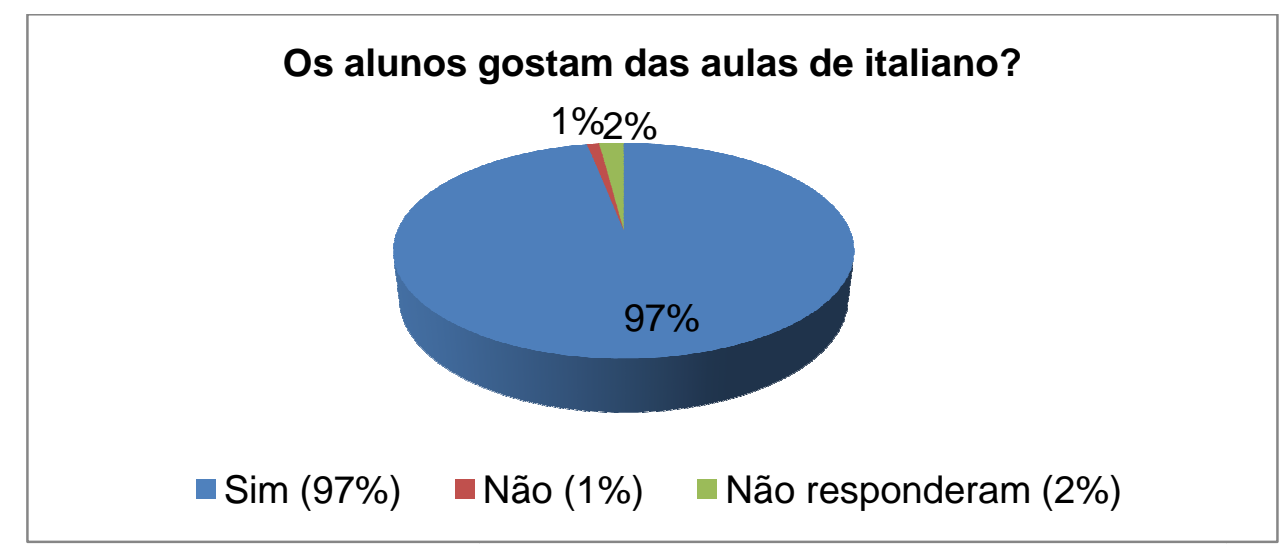

Gráfico 9 - Os discentes gostam das aulas de italiano?

Os estudantes apontaram diversos motivos pelos quais gostam das aulas de italiano. A seguir, citamos todas essas razões e o percentual de alunos que as mencionou:

- a possibilidade de aprender e praticar a língua italiana - 25\% dos discentes;

- o fato de as aulas serem interessantes e divertidas $-16 \%$;

- o fato de o professor ser bom/ competente - $13 \%$;

- o gosto pela língua-alvo - 13\%;

- a possibilidade de conhecer a cultura italiana -9\%;

- a possibilidade de fazer novas amizades $-8 \%$;

- o gosto por línguas em geral - 7\%;

- o fato de gostar da metodologia usada nas aulas $-3 \%$.

Somente $6 \%$ dos aprendizes não justificaram suas respostas a essa questão. É interessante notar que vários alunos (48\%) apontaram mais de um motivo que os faz gostar das aulas. 
Apenas três estudantes afirmaram não gostar de tais aulas: dentre eles, um não justificou sua resposta; e os outros dois disseram que não gostam das aulas, pois não lhes agrada estudar em grupo.

\subsubsection{Aspectos de que os alunos gostam e de que não gostam nas aulas de italiano}

Como mostramos anteriormente, $97 \%$ dos alunos do Italiano no Campus gostam das aulas. Vejamos, agora, o que eles preferem em tais aulas.

\section{Do que os alunos mais gostam nas aulas?}

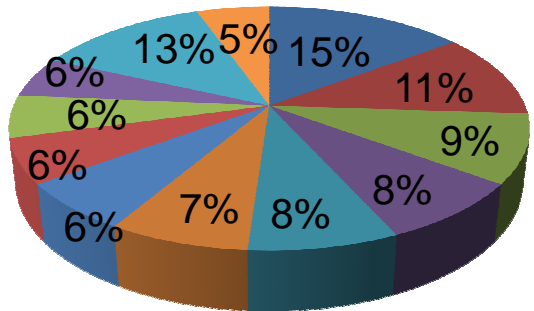

- Das atividades de conversação (15\%)

- De tudo (11\%)

Da leitura de textos (9\%)

- Da didática do professor (8\%)

Do professor (8\%)

Da convivência e interação com os colegas (7\%)

- Das atividades de escuta (6\%)

- Das atividades com músicas (6\%)

Das explicações gramaticais (6\%)

- Das informações sobre a cultura italiana (6\%)

- Outros (13\%)

Não responderam (5\%)

Gráfico 10 - Do que os alunos do IC mais gostam nas aulas de italiano?

Boa parte dos estudantes (27\%) afirmou que as atividades são os aspectos de que eles mais gostam nas aulas de italiano: $15 \%$ dos discentes disseram preferir as atividades de conversação; 6\% dos aprendizes, as atividades de escuta; e 6\%, as atividades com músicas.

Quarenta e seis alunos (11\%) disseram gostar de tudo nas aulas, o que mostra o quanto eles têm interesse por elas; $8 \%$ dos estudantes afirmaram gostar do professor, e $8 \%$ da didática do docente. Parece-nos que ao fazer uso do termo "didática", os aprendizes referem-se, na verdade, à abordagem de ensinar do professor, isto é, à forma 
como ele organiza a experiência de ensinar e aprender uma LE e que envolve um conjunto de conhecimentos, pressupostos, crenças e teorias concernentes ao que é uma língua e ao que é ensinar e aprender uma língua-alvo (cf. ALMEIDA FILHO, 1993).

Alguns estudantes (9\%) afirmaram gostar de ler textos nas aulas: alguns discentes (5\%) especificaram alguns gêneros textuais de sua preferência, mencionando contos, histórias em quadrinhos, artigos de jornal e receitas; outros alunos (3\%) disseram gostar da leitura dos diálogos do Linea diretta; outros (1\%), no entanto, não fizeram nenhum tipo de especificação. Assim, esses percentuais evidenciam haver, por parte dos aprendizes, uma preferência pela leitura de textos autênticos, embora alguns discentes gostem mais de ler textos didáticos.

A convivência e a interação com os colegas foram aspectos citados por $7 \%$ dos alunos. As explicações gramaticais foram um aspecto mencionado por vinte e três alunos, o que parece evidenciar que alguns deles gostam de estudar gramática e reconhecem a importância desse estudo nas aulas.

Vinte e dois aprendizes afirmaram que aquilo de que eles mais gostam nas aulas são as informações referentes à cultura italiana. Essa escolha dos alunos parece evidenciar a indissociabilidade entre língua e cultura nas aulas de italiano LE (e de outros idiomas). A maioria deles não explicitou se tais informações são obtidas por meio de textos autênticos e didáticos trabalhados na sala de aula, ou de conversas com o professor e os outros discentes. Alguns, contudo, esclareceram o que, para eles, consiste em uma fonte de informações sobre a cultura-alvo:

- "Materiais extras. Gosto de conhecer mais sobre a cultura italiana” (24 anos, nível I ${ }^{65}$ ).

- "Gosto dos materiais complementares, como músicas, filmes, textos jornalísticos, que nos ensinam sobre a cultura italiana" (44 anos, nível IV).

Ao analisar tais respostas e outras semelhantes a essas, parece-nos que, sob a ótica de alguns estudantes, os materiais são fontes de informações concernentes à cultura italiana. Na primeira resposta, a expressão "material extra" refere-se, possivelmente, ao material que não é o livro didático, ou melhor, ao material utilizado além deste. A segunda resposta parece especificar a categoria de material que, de acordo com a discente, mais oferece informações culturais: a dos materiais autênticos.

\footnotetext{
${ }^{65}$ Como o gênero dos alunos não é um fator relevante em nossa pesquisa, mencionamos, na maior parte desta dissertação, apenas a idade dos estudantes e o nível do Italiano no Campus que eles cursavam no segundo semestre de 2011.
} 
Convém ressaltar que alguns aprendizes citaram mais de um aspecto de que eles mais gostam nas aulas de italiano LE, como é possível notar nas seguintes respostas:

- "Gosto quando é necessário utilizar o diálogo entre os alunos, dinâmicas e exercícios que não estejam no livro" (24 anos, nível II).

- "Gosto de quando nós, alunos, temos que interagir com diálogos ou jogos, o que nos obriga a falar italiano e ajuda a adquirir certa fluência" (21 anos, nível I).

- "Gosto de aprender a falar em italiano coisas do dia-a-dia e da possibilidade de compreender filmes e músicas italianos sem recorrer constantemente a um dicionário" (22 anos, nível V).

No item "outros", estão inclusas outras atividades mencionadas pelos alunos, a saber: os jogos, as atividades de produção escrita e as atividades lexicais; cada uma delas foi citada por um número pequeno de alunos, respectivamente, quinze, doze e oito. Também fazem parte desse item os filmes e o livro didático, que foram mencionados, respectivamente, por dez e sete estudantes. Isso significa que o aspecto de que alguns alunos mais gostam é o material (tanto o autêntico quanto o didático).

No tocante à pergunta referente aos aspectos das aulas do IC dos quais os aprendizes não gostam, oitenta e dois discentes responderam que não há, nas aulas de italiano, algo de que eles não gostem. Muitos deles (cento e noventa e sete alunos), entretanto, apontaram alguns aspectos que, a seu ver, são problemáticos em tais aulas, como: o fato de alguns colegas falarem muito durante as aulas, atrapalhando, assim, o andamento das atividades; os exercícios repetitivos do livro didático; a má qualidade do equipamento de áudio usado no IC e a realização de provas. Apenas quinze aprendizes não responderam essa questão.

\subsubsection{Aspectos que os discentes consideram que poderiam ser melhores nas aulas de italiano LE}

Embora quase todos os estudantes do IC tenham afirmado gostar das aulas de italiano, eles apontaram alguns aspectos que poderiam ser melhores nelas. Para os discentes, as aulas seriam melhores se tivessem: maior variedade de materiais, mais atividades de conversação, uso frequente de recursos multimídia e equipamentos de áudio melhores. Esses aspectos foram, respectivamente, o primeiro, o segundo, o terceiro e o quarto mais citados pelos alunos. 
Isso mostra que não são apenas os teóricos da área da pedagogia de línguas que sustentam a ideia de que é importante que a sala de aula de LE tenha uma diversidade de materiais e atividades; os protagonistas do processo de ensino-aprendizagem de línguas estrangeiras também defendem a mesma ideia, como se vê nas seguintes respostas dadas pelos discentes:

- “[É necessário] Variar mais o material. Poderíamos assistir a um filme, debatê-lo, aprender com muitas músicas e um pouco de literatura, receitas e aulas sobre as regiões da Itália, suas peculiaridades - com muita imagem!” (60 anos, nível I).

- “Acho que o uso do livro poderia ser um recurso secundário, porque as aulas ficam monótonas. Poderíamos fazer uso de outros recursos, como filmes, músicas...” (28 anos, nível I).

- “[É importante] Não ficar preso a um livro. Aprender mais através de músicas, filmes" (46 anos, nível V).

- "No nível I, tivemos algumas aulas com um material de apoio do Lupo Alberto que foram bastante interessantes. Cheguei a entrar no site da RAI International e eles possuem algumas reportagens curtas que seria interessante mostrar nas aulas". (21 anos, nível IV).

Desse modo, a análise dos dados referentes aos aspectos que, segundo os discentes, poderiam tornar ainda melhores as aulas parece evidenciar a necessidade e a importância da utilização de diferentes materiais e diversas técnicas didáticas no processo de ensino-aprendizagem da língua-alvo.

\subsubsection{Os alunos do IC e o contato com a língua italiana fora da sala de aula}

Atualmente, para ter-se contato com uma língua estrangeira, não é preciso estar no país onde ela é falada. Hoje em dia, os diversos meios de comunicação (e, sobretudo, a internet) possibilitam esse contato a qualquer pessoa interessada em tê-lo. Quando se estuda uma LE em contextos formais de ensino-aprendizagem (aulas), o processo de apropriação da língua-alvo pode ser facilitado, se o contato com a LE não se restringir à sala de aula. Tendo em vista esse aspecto, vejamos, a seguir, se os discentes do Italiano no Campus têm contato com a língua-alvo fora das aulas. 


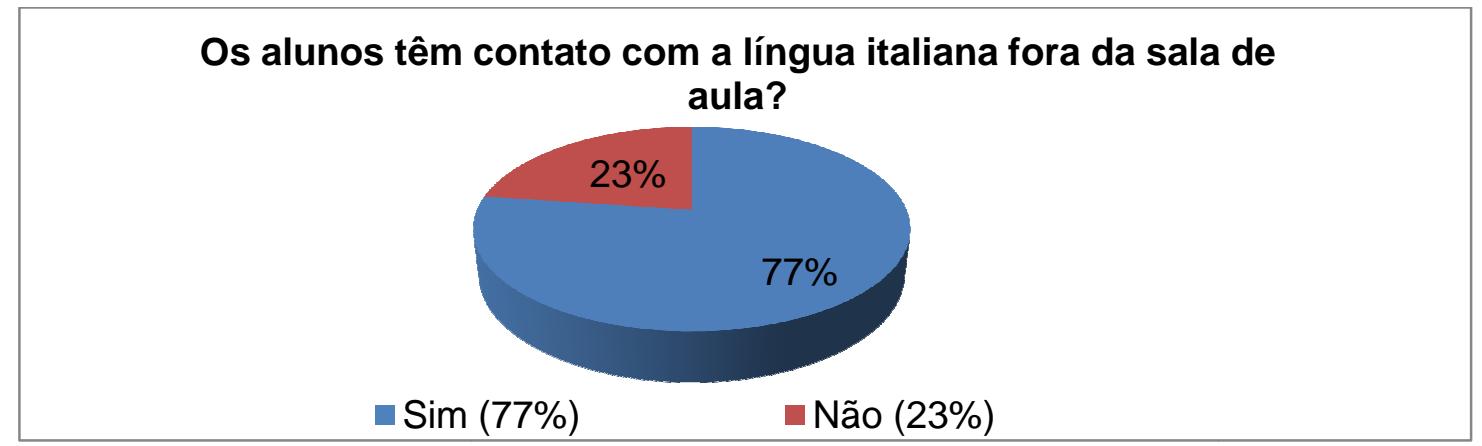

Gráfico 11 - Os estudantes do IC têm contato com a língua-alvo fora das aulas?

Pelo gráfico 11, é possível perceber que a maioria dos aprendizes procura manter contato com a língua italiana não apenas nas aulas, mas também fora delas: $87 \%$ dos estudantes afirmam que esse contato ocorre na casa deles; $5 \%$ dizem tê-lo no local de trabalho, e 8\% não especificaram o local onde eles mantêm tal contato.

A maior parte dos discentes do IC afirmou que procura ter contato com a línguaalvo por meio de diversos materiais, conforme ilustrado no gráfico abaixo:

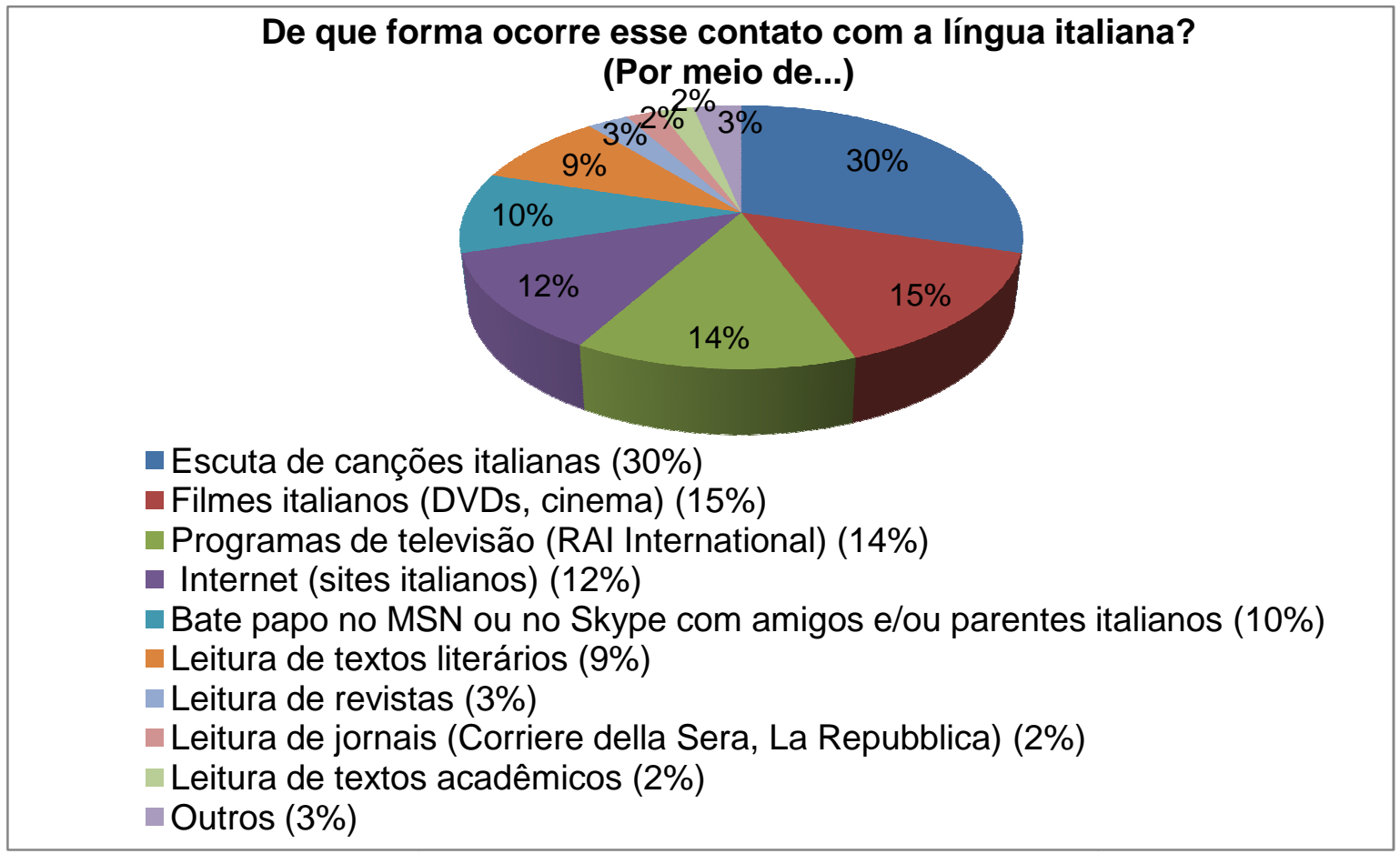

Gráfico 12 - Formas de contato que os alunos do IC estabelecem com o italiano fora da sala de aula

Possivelmente, os estudantes tentam manter contato com a língua-alvo fora das aulas por estarem conscientes de que isso poderá ajudá-los no processo de aprendizagem 
da LE. Vejamos, em alguns depoimentos, qual a categoria de material preferida para esse contato:

- "Eu costumo ler sites em italiano em que há notícias, vídeos, receitas e até jogos" (62 anos, nível VI).

- "Vejo filmes italianos que baixo da internet e tenho dois amigos na Itália, com quem eu converso via Skype quando possível” (42 anos, nível VIII).

- "Leio muitos textos em italiano por conta do doutorado e adoro escutar canções italianas" (30 anos, nível V).

- "Procuro aumentar esse contato por meio de música e cinema" (19 anos, nível I).

\subsection{As atividades preferidas pelos estudantes do IC}

$\mathrm{Na}$ pergunta $\mathrm{n}^{\mathrm{o}} 10$ do questionário que os alunos preencheram, dividimos as atividades em categorias, a saber: atividades de compreensão oral, de compreensão escrita, de produção oral, de produção escrita, gramaticais, lexicais e lúdicas. As atividades não são, muitas vezes, separáveis, isto é, dependendo da maneira como elas são elaboradas e propostas, podem ter como objetivo o desenvolvimento de mais de uma habilidade; por exemplo, uma mesma atividade pode visar ao desenvolvimento da compreensão oral e da produção escrita ao mesmo tempo; pode, também, ser uma atividade lúdica e, simultaneamente, lexical etc.

Entretanto, para facilitar a organização dos dados coletados, pareceu-nos útil dividir as atividades em categorias, que são as já mencionadas. Além disso, tínhamos o receio de que se a questão fosse simplesmente “quais atividades você prefere?", os alunos tivessem dificuldade de identificá-las ou de lembrar-se delas e, portanto, deixassem de responder tal pergunta, que é fundamental para a nossa investigação, visto que as atividades consistem nas técnicas didáticas que nos auxiliam no trabalho com os materiais autênticos, objeto de nossa pesquisa.

Por isso, optamos por elaborar a pergunta $\mathrm{n}^{\circ} 10 \mathrm{em}$ forma de questão fechada. Ainda assim, no momento de organizar os dados, alguns aspectos dificultaram nosso trabalho: 
- o fato de alguns alunos (no total, onze) terem assinalado algumas atividades com um $\mathrm{X}$, em vez de terem usado numerais para estabelecer classificações das atividades. Isso invalidou as respostas desses estudantes;

- o fato de alguns aprendizes (oito) terem misturado X e numerais também fez com que tivéssemos de desconsiderar suas respostas;

- em vez de utilizarem os numerais de 1 a 5 para estabelecer uma classificação das atividades (na qual 1 é a primeira classificada e, portanto, a atividade preferida, e 5, a última e, desse modo, a atividade de menor preferência), alguns alunos (dezesseis, no total) consideraram tais numerais como notas, isto é, o 1 seria a nota mais baixa, e o 5, a nota mais alta. No entanto, os alunos que o fizeram, especificaram isso na questão, escrevendo frases como estas: "utilizei o critério de nota", "considerei 5 a atividade de que mais gosto, e 1 a de que não gosto". Assim, tendo em vista essa especificação, foi possível considerar válidas tais respostas, no momento de fazer a tabulação e a análise dos dados.

Desse modo, das duzentas e noventa e quatro respostas, tivemos de descartar dezenove, ou seja, para analisar os dados referentes à questão 10, levamos em conta duzentas e setenta e cinco respostas.

Durante a aplicação do questionário, alguns estudantes nos perguntaram se eles poderiam, por exemplo, usar o numeral 1 para dois tipos de atividade de compreensão oral, alegando que gostam igualmente de ambos. Ao elaborarmos essa questão, não tínhamos considerado essa possibilidade, por isso demos uma resposta afirmativa aos discentes quanto a essa importante pergunta que eles nos fizeram. Portanto, em alguns gráficos relacionados à questão 10, algumas vezes, o total de respostas foi superior ao número total de alunos que responderam o questionário.

Para preparar cada gráfico, levamos em consideração as atividades de cada categoria escolhidas como primeira opção pelos aprendizes, isto é, contamos quantas vezes cada atividade de cada categoria foi indicada com o numeral 1 pelos alunos.

Convém ressaltar que muitos estudantes, embora tenham numerado de 1 a 5 as atividades de cada categoria, assinalaram com a letra $\mathrm{N}$ várias dessas atividades; isto é, eles indicaram as atividades que eles prefeririam que fossem trabalhadas nas aulas, mas que, na verdade, não foram utilizadas, ainda, nas aulas que eles já tiveram no IC. A seguir, vejamos quais são as preferências dos discentes no tocante aos diferentes tipos de atividades. 


\subsubsection{As preferências dos aprendizes quanto às atividades de compreensão oral}

No que concerne às atividades de compreensão oral, como podemos ver no gráfico 13, a maior parte dos estudantes (58\%) gosta mais daquelas em que são utilizados materiais autênticos, como canções, filmes, documentários e telejornais; $34 \%$ dos discentes preferem atividades que envolvem o livro didático; e $8 \%$ deles gostam mais daquelas em que se usam outros textos autênticos, como publicidades, entrevistas e transmissões radiofônicas.

\section{Atividades de compreensão oral preferidas pelos alunos do IC}

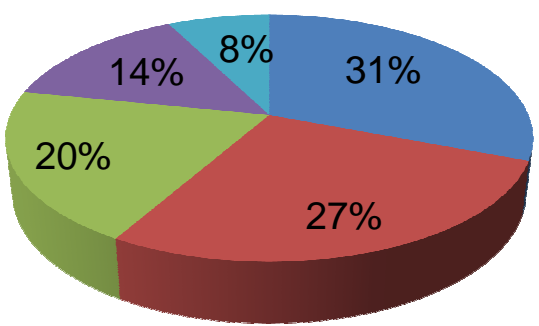

- Ouvir canções e completar lacunas e/ou responder questões referentes a essas canções $(31 \%)$

- Assistir a um vídeo (filme, documentário, telejornal etc) e fazer anotações e/ou responder perguntas com base nele (27\%)

- Ouvir textos do CD que acompanha o livro didático (em geral, diálogos) e preencher lacunas e/ou responder questões sobre eles (20\%)

- Escrever palavras, frases etc ditadas pelo professor e/ou completar textos dos exercícios de ditado do livro didático (14\%)

- Ouvir textos de transmissões radiofônicas e/ou da internet, tais como entrevistas, publicidades, notícias, entre outros e preencher lacunas e/ou responder perguntas sobre eles $(8 \%)$

Gráfico 13 - Quais atividades de compreensão oral os alunos do IC preferem?

Na questão 10, abaixo de cada categoria de atividades, havia um espaço para que os estudantes citassem outras atividades que eles consideram importantes e fizessem comentários. Quanto às atividades de compreensão oral, não foram mencionadas outras atividades pelos discentes, e apenas uma aluna de 32 anos do nível V fez um comentário: "Temos poucos exercícios com filmes. Gostaria que houvesse mais!".

Muitos estudantes (cento e setenta e cinco) disseram que algumas das atividades de compreensão oral que mencionamos nunca foram realizadas nas aulas de italiano que eles tiveram. 
Para interpretar o gráfico abaixo, bem como todos aqueles em que serão mostradas as atividades que, segundo os discentes, não foram aplicadas nas aulas de italiano LE, é preciso considerar que as atividades mais votadas pelos alunos foram, muito provavelmente, as menos utilizadas nas aulas em questão. O gráfico seguinte ilustra as atividades de compreensão oral que, de acordo com os alunos, não foram usadas nas aulas.

\section{Atividades de compreensão oral que, segundo os alunos, não foram realizadas nas aulas de italiano que eles tiveram}

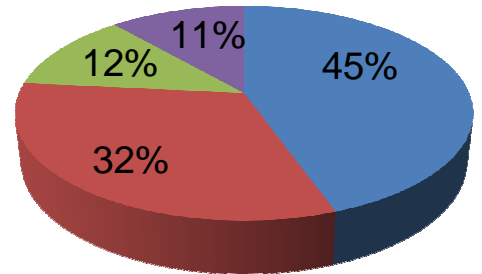

- Ouvir textos de transmissões radiofônicas e/ou da internet, tais como entrevistas, publicidades, notícias, entre outros e preencher lacunas e/ou responder perguntas sobre eles (45\%)

- Assistir a um vídeo (filme, documentário, telejornal etc) e fazer anotações e/ou responder perguntas com base nele (32\%)

- Escrever palavras, frases etc ditadas pelo professor e/ou completar textos dos exercícios de ditado do livro didático (12\%)

- Ouvir canções e completar lacunas e/ou responder questões referentes a essas canções $(11 \%)$

Gráfico 14 - Atividades que, segundo os discentes do IC, não foram realizadas nas aulas que eles já tiveram

É importante notar que nenhum aluno mencionou a atividade que envolve a escuta dos diálogos do CD que acompanha o livro didático, o que significa que tal atividade já foi trabalhada nas aulas de italiano que os estudantes já tiveram. Todos os professores/monitores do Italiano no Campus têm de usar o mesmo LD e, visto que este contém um $\mathrm{CD}$, todos os professores precisam, necessariamente, fazer uso desse material de áudio. Portanto, ouvir os textos orais de tal CD é uma atividade intrínseca à utilização do Linea diretta desde o primeiro nível. Dentre as atividades de compreensão oral mencionadas, esta é, desse modo, a realizada com maior frequência.

A observação do gráfico 14 permite-nos deduzir que as atividades em que se empregam canções, além de serem as prediletas dos discentes, também são as segundas mais utilizadas pelos docentes no IC. Isso dá margem a duas interpretações possíveis: a 
primeira é a de que essas são as atividades preferidas pelos alunos justamente porque são algumas das mais usadas pelos professores; a segunda é a de que os docentes utilizam frequentemente tais atividades por saberem que os aprendizes gostam muito delas e têm preferência por esse material autêntico.

\subsubsection{As opiniões dos estudantes no tocante às atividades de compreensão escrita}

No que concerne às atividades de compreensão escrita, vejamos, a seguir, quais são as preferências dos discentes:

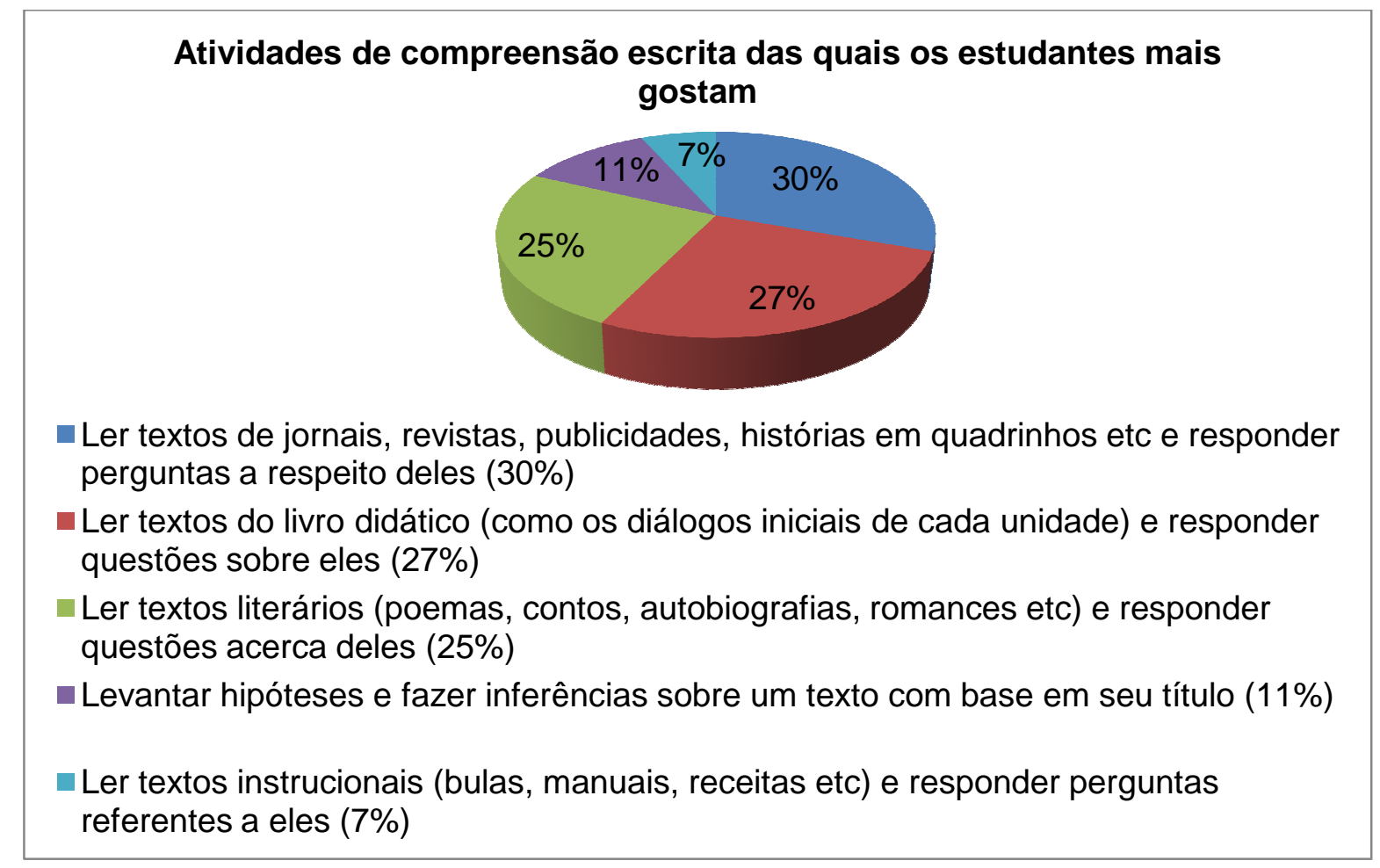

Gráfico 15 - De quais atividades de compreensão escrita os estudantes do IC mais gostam?

Também nessa categoria de atividades, aquelas de que os alunos mais gostam são as que se utilizam de materiais autênticos, em detrimento do livro didático, como se vê em alguns depoimentos:

- “Coisas extra-livro são sempre mais interessantes!” (19 anos, nível II).

- "Seria ótimo ler textos jornalísticos e literários nas aulas" (26 anos, nível I).

- "Gostaria de ter exercícios com textos de jornais e revistas italianos" (32 anos, nível $\mathrm{V})$. 
Na primeira resposta, ao usar a expressão "coisas extra-livro", o estudante do nível II quis dizer, possivelmente, que as atividades de compreensão escrita mais interessantes, a seu ver, são aquelas que não estão no LD, ou que, pelo menos, não se limitam a ele. As outras duas respostas fazem menção a textos autênticos de diferentes domínios discursivos (jornalístico, literário) e a dois suportes (jornal, revista).

Nessas duas últimas respostas, as discentes utilizam verbos no futuro do pretérito, o que pode indicar que ainda não foi realizada a vontade delas de que as atividades de compreensão escrita baseadas nesses textos autênticos sejam usadas nas aulas de italiano.

Ainda quanto às atividades de leitura, de acordo com muitos aprendizes (no total, duzentos e dezenove), várias delas não foram trabalhadas nas aulas que eles já tiveram.

\section{Atividades de compreensão escrita que, de acordo com os estudantes, não foram trabalhadas nas aulas de italiano}

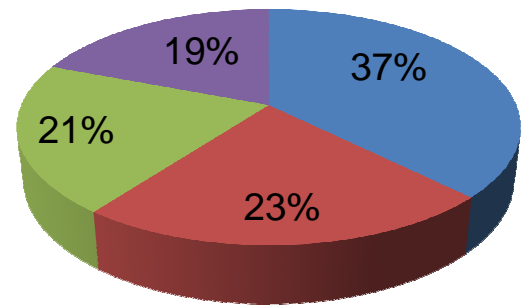

- Ler textos instrucionais (bulas, manuais, receitas etc) e responder perguntas referentes a eles (37\%)

- Ler textos de jornais, revistas, publicidades, histórias em quadrinhos etc e responder perguntas a respeito deles $(23 \%)$

- Ler textos literários (poemas, contos, autobiografias, romances etc) e responder questões acerca deles (21\%)

- Levantar hipóteses e fazer inferências sobre um texto com base em seu título (19\%)

Gráfico 16 - Atividades de compreensão escrita que, segundo os alunos, não foram trabalhadas nas aulas de italiano do IC

Como podemos observar no gráfico 16, não foi citada pelos discentes a atividade de leitura de textos do livro didático. Isso se deve ao motivo que já mencionamos: todos os professores/monitores usam, obrigatoriamente, o LD; ou seja, todos os alunos do Italiano no Campus já leram textos contidos nesse suporte.

Também de acordo com os dados mostrados em tal gráfico, as atividades de compreensão escrita menos usadas são aquelas em que se empregam os textos autênticos instrucionais, e as mais utilizadas (depois das que se referem à leitura de textos do manual 
didático) são as que dizem respeito ao levantamento de hipóteses e à elaboração de inferências a partir do título de um texto.

\subsubsection{As preferências dos discentes no tocante às atividades de produção oral}

No que concerne às atividades de produção oral (que, como vimos no gráfico 10 , consistem no aspecto de que vários estudantes mais gostam nas aulas de italiano), vejamos quais são as preferências dos discentes.

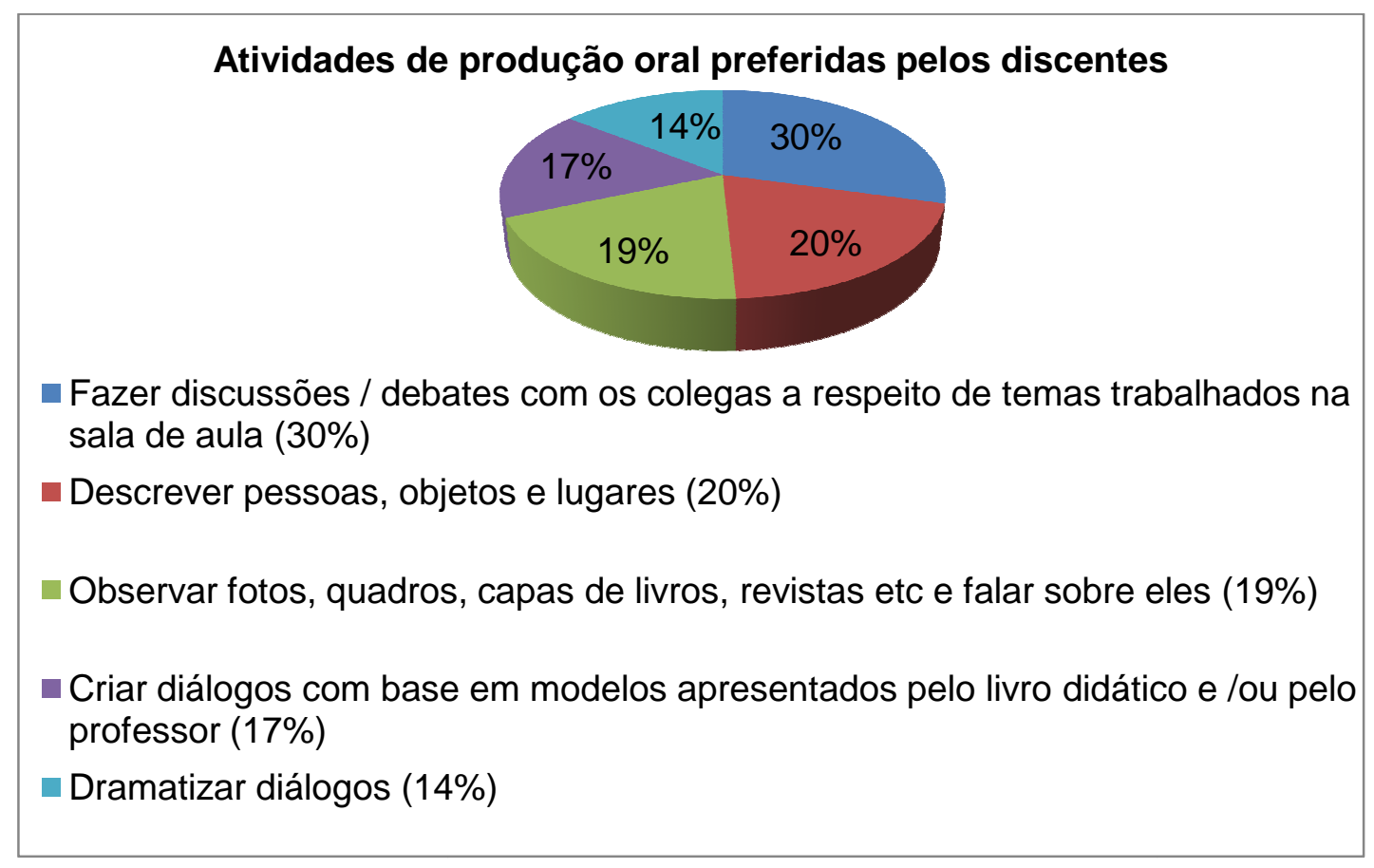

Gráfico 17 - Atividades de produção oral das quais os estudantes do IC mais gostam

Observando-se o gráfico 17, percebe-se que as atividades de produção oral preferidas pelos aprendizes são aquelas em que eles não precisam seguir modelos, podendo expressar-se livremente com relação a temas trabalhados nas aulas; é o que ilustra a resposta de uma aluna de 28 anos do nível VI: “As aulas de prática oral mais interessantes até hoje, para mim, foram aquelas em que discutimos temas atuais, a partir de textos extras, de jornais e revistas, por exemplo".

Tal resposta não apenas ressalta o tipo de atividade de produção oral de que essa estudante mais gosta, como também a categoria de material que ela prefere para realizar a atividade: a dos materiais autênticos. Ainda conforme esse gráfico, as atividades de que 
os estudantes menos gostam são aquelas em que eles devem elaborar diálogos a partir de modelos ou dramatizá-los.

Assim, parece-nos que os alunos do Italiano no Campus têm uma preferência por atividades de produção oral mais livres, em detrimento das mais dirigidas; ou seja, parece que, nas aulas, eles gostam mais de falar para expressarem suas opiniões e comunicaremse com os colegas do que para produzir textos orais com base em modelos propostos pelo LD e/ou pelo professor.

Um aprendiz de 42 anos do nível VIII mencionou outra atividade de produção oral que, a seu ver, deveria ser trabalhada nas aulas de italiano: "Conversar com alguém (de preferência, nativo) via Skype com um computador portátil, e a turma ir respondendo".

Seria difícil colocar em prática tal atividade, pois precisaríamos da colaboração de algum de nossos amigos italianos que estivesse disponível exatamente no horário de nossas aulas, o que praticamente não ocorre. Contudo, a sugestão desse aluno parece-nos bastante interessante e passará a fazer parte de nossa lista de atividades de produção oral a serem realizadas futuramente.

Vejamos, a seguir, quais são as atividades de tal categoria que, de acordo com alguns estudantes (cento e setenta e oito, no total), ainda não foram propostas nas aulas:

\section{Atividades de produção oral as quais, segundo os discentes, não foram utilizadas nas aulas de italiano LE}

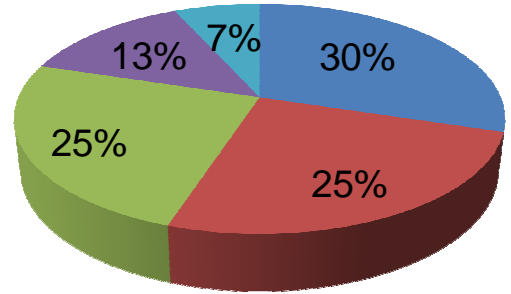

- Observar fotos, quadros, capas de livros, revistas etc e falar sobre eles (30\%)

- Dramatizar diálogos (25\%)

Descrever pessoas, objetos e lugares (25\%)

- Fazer discussões/ debates com os colegas a respeito de temas trabalhados na sala de aula (13\%)

- Criar diálogos com base em modelos apresentados pelo livro didático e/ou pelo professor $(7 \%)$

Gráfico 18 - Atividades de produção oral as quais, segundo os discentes, não foram utilizadas em suas aulas de italiano LE 
A leitura do gráfico 18 permite-nos dizer que as atividades de produção oral menos usadas no IC são, segundo alguns alunos, aquelas em que se devem observar fotos, quadros, capas de livros etc e falar a respeito deles; e as mais utilizadas são algumas daquelas de que os estudantes menos gostam, ou seja, a criação de diálogos com base em modelos.

\subsubsection{As atividades de produção escrita prediletas dos aprendizes}

Quanto às atividades de produção escrita, vejamos quais são as preferências dos alunos do Italiano no Campus.

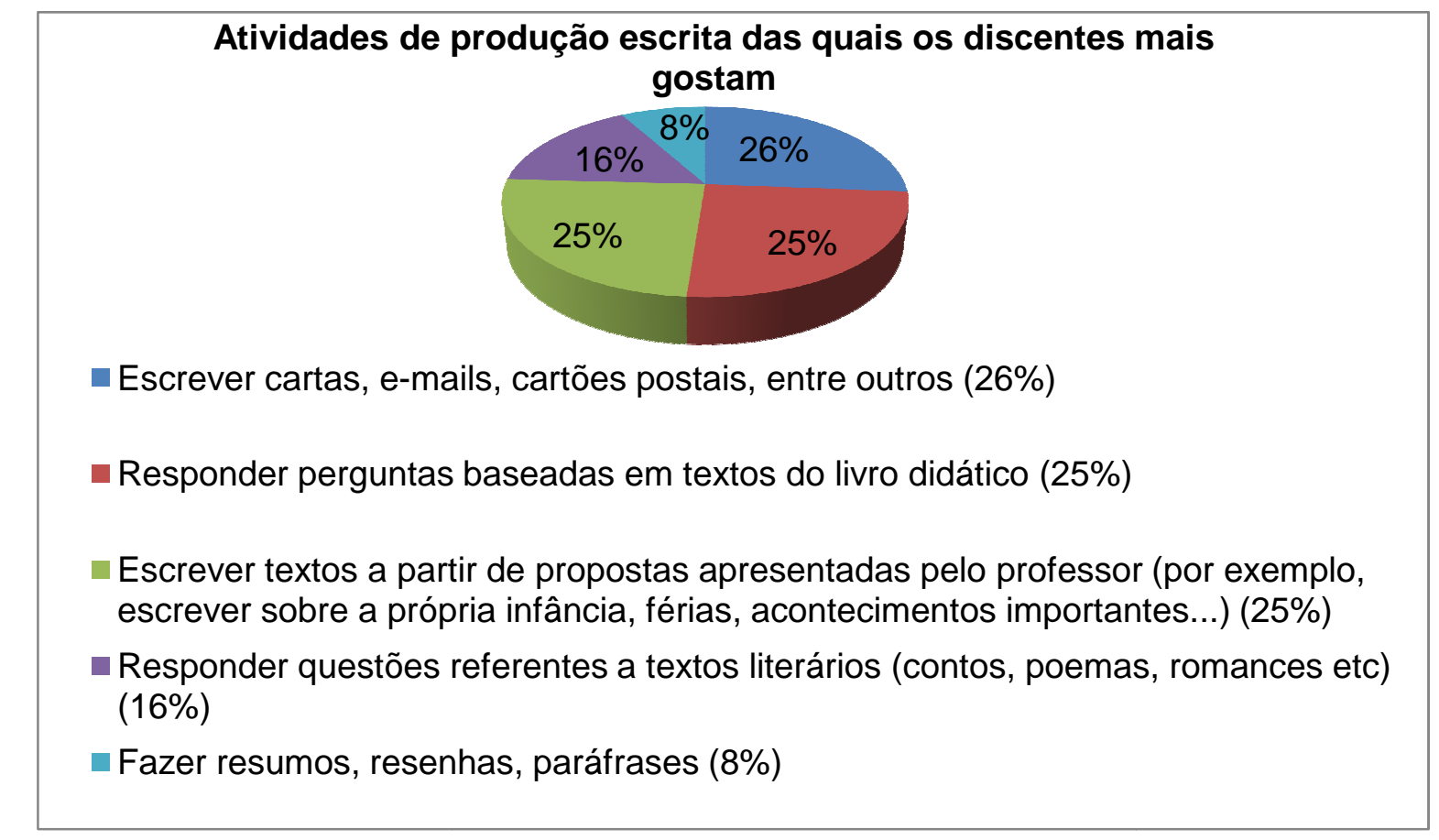

Gráfico 19 - Atividades de produção escrita preferidas pelos estudantes do IC

Como se vê no gráfico 19, os alunos gostam, principalmente, das atividades em que eles têm de escrever cartas, e-mails, cartões postais etc. Ademais, os aprendizes gostam, igualmente, das atividades em que eles devem responder questões baseadas em textos do LD e daquelas nas quais eles têm de escrever textos a partir de propostas apresentadas pelo professor.

As atividades de que os discentes menos gostam são aquelas em que eles precisam responder perguntas referentes a textos literários e fazer resumos, resenhas e paráfrases. 
Apenas duas estudantes fizeram comentários quanto a essa categoria de atividades, os quais transcrevemos abaixo:

- "Eu detesto escrever em qualquer língua" (44 anos, nível IV).

- "Produção de texto é mais legal do que responder questões" (19 anos, nível II).

A primeira resposta revela uma preferência pessoal da estudante do nível IV, que afirma não gostar de produzir textos escritos nem mesmo em sua própria língua materna. O segundo comentário, por sua vez, mostra que, para a aluna do nível II, responder questões não é uma forma de produzir textos. Talvez, ao utilizar a expressão "produção de texto", essa discente esteja se referindo à escrita de diferentes gêneros textuais, como as cartas, os e-mails, os resumos, entre outros.

Vejamos, abaixo, quais são as atividades de produção escrita que, de acordo com muitos alunos (no total, cento e sessenta e dois), não foram trabalhadas nas aulas de italiano que eles já tiveram.

\section{Atividades de produção escrita as quais, de acordo com os alunos, não foram trabalhadas nas aulas}

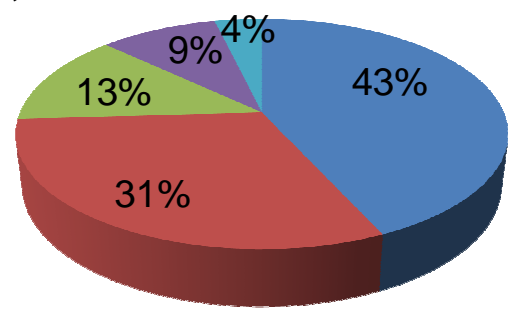

- Fazer resumos, resenhas, paráfrases (43\%)

- Responder questões referentes a textos literários (contos, poemas, romances etc) $(31 \%)$

- Escrever textos a partir de propostas apresentadas pelo professor (por exemplo, escrever sobre a própria infância, férias, acontecimentos importantes...) (13\%)

- Escrever cartas, e-mails, cartões postais, entre outros (9\%)

- Responder perguntas baseadas em textos do livro didático (4\%)

Gráfico 20 - Atividades de produção escrita que, de acordo com os alunos do IC, não foram utilizadas nas aulas

Ao observar o gráfico 20, podemos dizer que, segundo os alunos, a atividade de produção escrita mais trabalhada nas aulas do IC consiste em responder questões baseadas em textos do LD. Isso, provavelmente, é devido à obrigatoriedade do uso do livro didático. Por sua vez, as atividades menos utilizadas são exatamente aquelas de que a minoria dos discentes gosta, isto é, a escrita de resumos, resenhas e paráfrases. 


\subsubsection{As opiniões dos discentes no que concerne às atividades gramaticais}

Agora que já apresentamos e comentamos os dados referentes às opiniões dos estudantes quanto às atividades que visam ao desenvolvimento das quatro habilidades básicas, vejamos as percepções deles com relação às atividades gramaticais.

\section{Atividades gramaticais preferidas pelos estudantes}

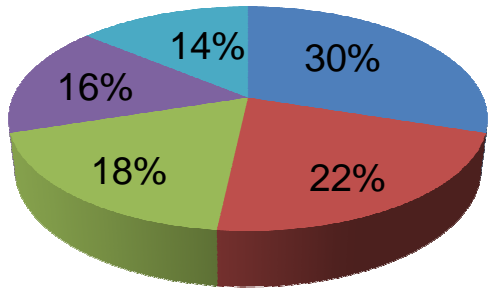

- Transformar frases e/ou textos (do singular para o plural e vice-versa; do presente para o passado; do presente para o futuro; entre outras) (30\%)

- Descobrir qual é a regra segundo a qual se deve utilizar uma determinada estrutura (exemplo: descobrir por que se diz "il gatto" / "i gatti") (22\%)

- Fazer exercícios de repetição (aqueles em que você tem de seguir o modelo) (18\%)

- Fazer exercícios de substituição (por exemplo, reescrever as frases substituindo as palavras em negrito pelos pronomes diretos) (16\%)

- Questões de múltipla escolha (por exemplo, assinalar a frase correta) (14\%)

Gráfico 21 - Atividades gramaticais de que os alunos do IC mais gostam

O gráfico 21 mostra que as atividades de gramática que os discentes preferem são as de transformação de frases e textos, embora os alunos não tenham feito comentários a respeito de tais exercícios. O segundo tipo de atividade gramatical de que eles mais gostam refere-se à descoberta de regras, isto é, a exercícios que visam ao ensino indutivo da gramática.

Já o terceiro tipo de atividade gramatical preferido pelos aprendizes é o de repetição. O quarto tipo de atividade gramatical de que os alunos mais gostam é o de substituição, e o quinto e último, as questões de múltipla escolha. Vejamos alguns comentários feitos pelos alunos do IC quanto às atividades gramaticais:

- "Os exercícios são muito importantes para gravar mais a gramática e para compreensão das regras” (55 anos, nível I).

- "Adoro exercícios gramaticais, gosto de regras, pena que o italiano tenha tantas exceções!” (62 anos, nível III).

- "Acho que falta mais exercícios gramaticais no curso" (30 anos, nível V). 
- "O curso é bastante voltado para atividades gramaticais" (68 anos, nível V).

Os dois primeiros comentários confirmam que, para os aprendizes, é importante estudar a gramática, que, para eles, parece ser sinônimo de regras; ou seja, geralmente, ao pensar em gramática, os discentes pensam na gramática normativa, que, como todos sabemos, tem um caráter prescritivo e, portanto, "dita" as regras às quais os falantes de uma língua deveriam obedecer.

O terceiro e o quarto comentários, por sua vez, parecem ser contraditórios entre si: enquanto para uma aluna, há poucos exercícios gramaticais nas aulas do IC; para a outra, o curso concentra-se nas atividades dessa categoria. Isso mostra as diferentes percepções dos estudantes com relação às atividades gramaticais trabalhadas nas aulas.

Vejamos, a seguir, quais são as técnicas didáticas voltadas para o ensinoaprendizagem da gramática que não costumam ser aplicadas na sala de aula, de acordo com os setenta e um discentes que as indicaram com a letra $\mathrm{N}$, conforme solicitado no enunciado da questão 10 .

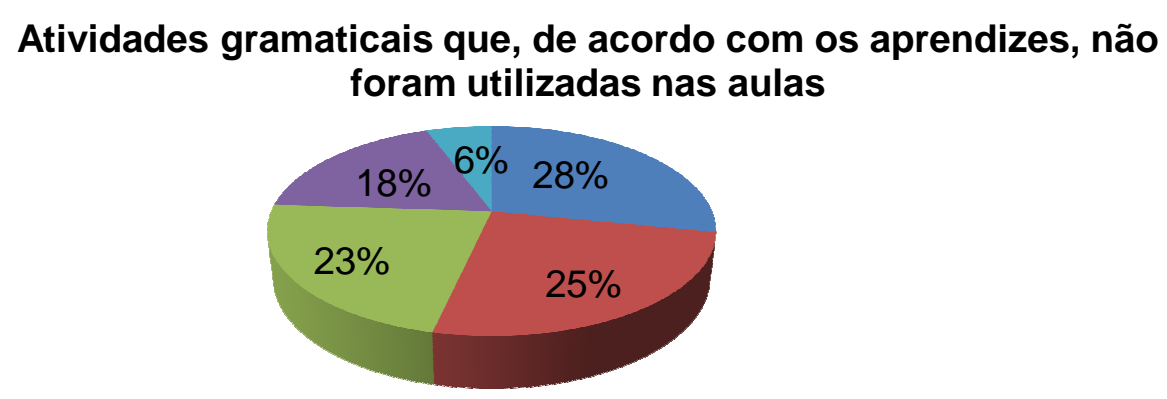

- Questões de múltipla escolha (por exemplo, assinalar a frase correta) (28\%)

- Exercícios de substituição (por exemplo, reescrever as frases substituindo as palavras em negrito pelos pronomes diretos) (25\%)

- Transformação de frases e/ou textos (do singular para o plural e vice-versa; do presente para o passado; do presente para o futuro; entre outras) (23\%)

- Descobrir qual é a regra segundo a qual se deve utilizar uma determinada estrutura (exemplo: descobrir por que se diz "il gatto" / "i gatti") (18\%)

- Exercícios de repetição (aqueles em que você tem de seguir o modelo) (6\%)

Gráfico 22 - Atividades gramaticais que, de acordo com os aprendizes, não foram aplicadas nas aulas do IC

As questões de múltipla escolha foram, como se vê no gráfico 22, as mais votadas pelos discentes, o que significa que elas são as atividades gramaticais menos usadas nas aulas de italiano LE e, talvez, por esse motivo, sejam aquelas de que os alunos menos 
gostam; ou, talvez, os professores as usem pouco justamente por saberem que os estudantes não gostam delas. Já os exercícios de repetição foram apontados por apenas $6 \%$ dos estudantes, o que indica que esse tipo de atividade gramatical é bastante utilizado nas aulas do IC.

\subsubsection{As percepções dos aprendizes quanto às atividades lexicais}

Vejamos, a seguir, as preferências de nossos alunos quanto às atividades que focalizam o léxico:

\begin{tabular}{|l|}
\hline \multicolumn{2}{|c|}{ Atividades lexicais preferidas pelos alunos } \\
Associar palavras às imagens (31\%) \\
Fazer traduções (21\%) \\
Associar palavras aos seus respectivos sinônimos (20\%) \\
Associar palavras aos seus respectivos antônimos (14\%) \\
Eliminar a palavra que não pertence ao mesmo campo lexical das outras (exemplo: \\
cane, gatto, albero, coniglio) (14\%)
\end{tabular}

Gráfico 23 - Atividades lexicais de que os estudantes do IC mais gostam

O gráfico 23 mostra que as atividades lexicais preferidas pelos aprendizes são aquelas em que eles devem associar palavras às imagens. A preferência deles por esse tipo de atividade está, possivelmente, ligada a aspectos neurolinguísticos: como vimos no capítulo 3 desta dissertação, $80 \%$ das informações são percebidas pelo cérebro por meio da visão; por esse motivo, Danesi (1998) ressalta a importância da aplicação de técnicas didáticas que possibilitem aos aprendizes a associação entre elementos verbais e imagéticos.

O segundo tipo de atividade lexical de que os alunos mais gostam diz respeito à feitura de traduções, a principal técnica didática empregada pelo mais antigo método de ensino-aprendizagem de línguas: o gramática e tradução. Atualmente, tal atividade é 
condenada por muitos professores e teóricos da área da pedagogia de línguas. No entanto, como se vê no gráfico 23 , essa técnica é bastante apreciada pelos discentes do Italiano no Campus.

A associação de sinônimos, de antônimos e a eliminação de palavras são, respectivamente, o terceiro, o quarto e o quinto tipos de atividade lexical dos quais os estudantes do IC mais gostam. Vejamos, a seguir, quais são as atividades lexicais que, segundo alguns aprendizes (cento e vinte e cinco, no total), não costumam ser aplicadas nas aulas de italiano LE.

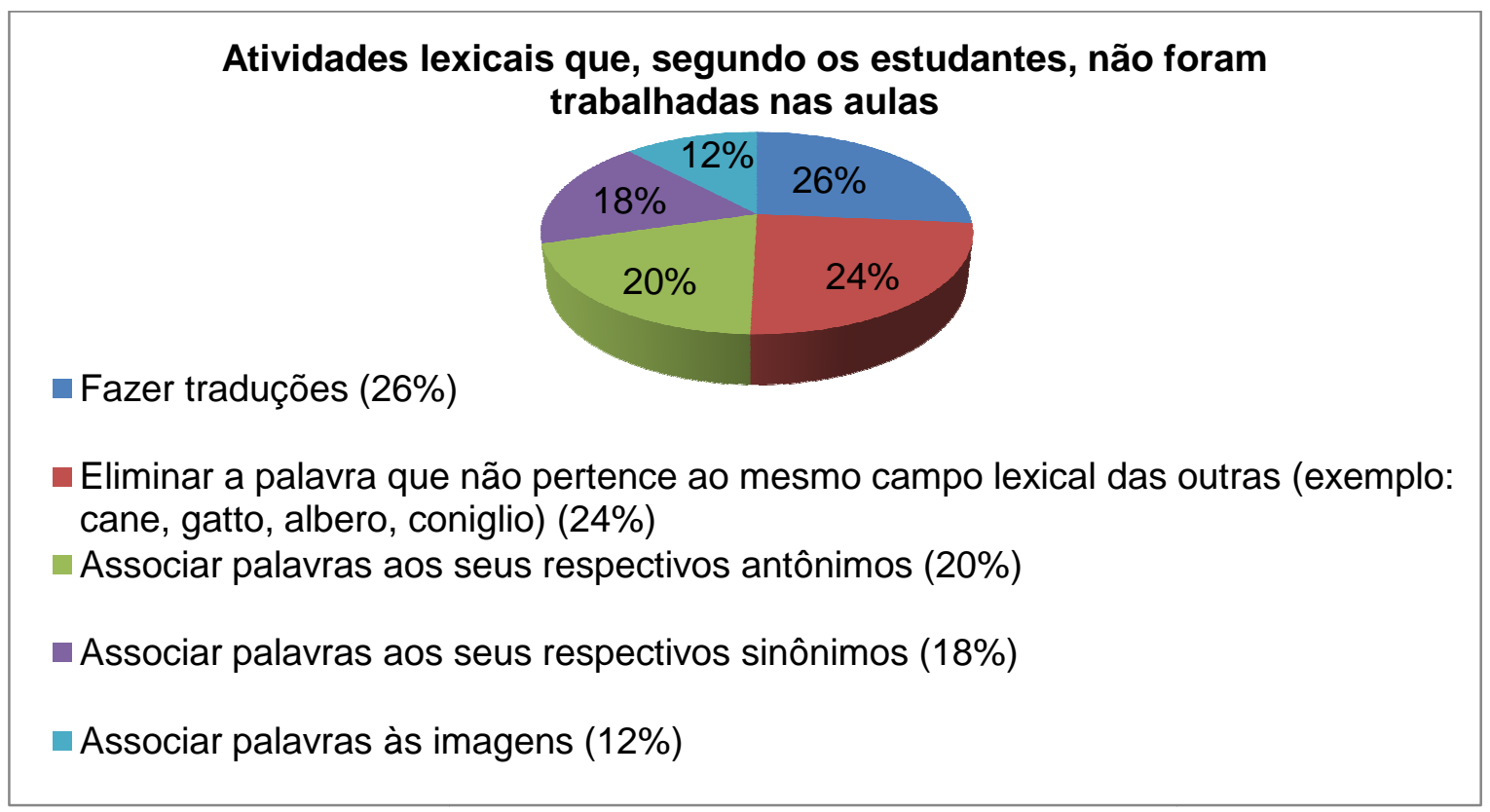

Gráfico 24 - Atividades lexicais que, segundo os estudantes do IC, não foram trabalhadas nas aulas

A atividade mais votada pelos discentes e, portanto, a que costuma ser menos utilizada nas aulas do Italiano no Campus é a de fazer traduções, embora esta seja o segundo tipo de atividade lexical de que nossos alunos mais gostam. Pelo gráfico 24, nota-se, também, que a atividade menos citada pelos aprendizes é a associação entre palavras e imagens, o que nos leva a crer que ela seja uma técnica bastante empregada pelos professores nas aulas do IC.

\subsubsection{As atividades lúdicas preferidas pelos alunos do Italiano no Campus}

Vejamos quais são as preferências dos discentes quanto às atividades lúdicas: 
Atividades lúdicas de que os alunos mais gostam

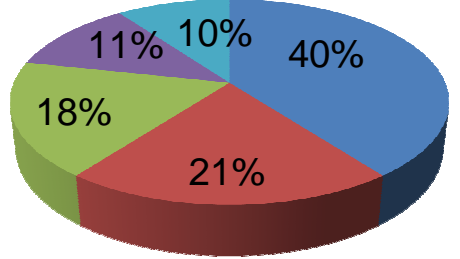

- Jogos $(40 \%)$

- Quiz (21\%)

Exercícios com piadas (18\%)

- Mímicas (11\%)

- Exercícios baseados em charadas (10\%)

Gráfico 25 - Atividades lúdicas preferidas pelos estudantes do IC

O gráfico mostra que os jogos são as atividades lúdicas de que os aprendizes do IC mais gostam; na classificação estabelecida pelos estudantes, estão, após os jogos, respectivamente, o quiz (conjunto de perguntas feitas, geralmente, de maneira lúdica), os exercícios com piadas, as mímicas e os exercícios baseados em charadas.

A respeito das técnicas lúdicas utilizadas nas aulas de LE, Baccin (2007, p. 11) afirma que

\begin{abstract}
As atividades lúdicas em sala de aula não são apenas uma técnica de relaxamento ou descontração, ou uma atividade complementar quando restam alguns minutos antes do final da aula. São importantes instrumentos que podem ser utilizados em todas as etapas da unidade didática (...). Com os jogos didáticos, além de estruturas gramaticais, podemos apresentar e trabalhar as funções comunicativas e os elementos culturais.
\end{abstract}

Os comentários que alguns alunos fizeram acerca de tais atividades corroboram a afirmação da autora no que se refere à importância dessas técnicas didáticas no processo de ensino-aprendizagem da LE; por isso, transcrevemo-los a seguir:

- "Gosto de atividades lúdicas pelo fato de auxiliarem na memorização da matéria" (55 anos, nível I).

- "Práticas lúdicas são divertidas e proporcionam fixação do vocabulário" (39 anos, nível I).

- "Ter atividades lúdicas seria um jeito legal de estudar às vezes com mais dinamismo" (22 anos, nível II).

É possível perceber também, por esses comentários, que, para alguns estudantes, as atividades lúdicas consistem em uma maneira de adquirir o léxico e memorizar diferentes conteúdos, além de tornar as aulas mais divertidas e dinâmicas. No entanto, em todas as respostas que analisamos nesta pesquisa, havia cinco nas quais se percebia que 
alguns alunos não gostam muito dessa categoria de atividades, como se percebe no comentário feito por uma aluna de 60 anos do nível II: “[As atividades lúdicas] Não me agradam muito".

Vejamos, agora, quais são, de acordo com alguns aprendizes (no total, duzentos e quinze), as técnicas lúdicas que, geralmente, não são empregadas nas aulas do Italiano no Campus.

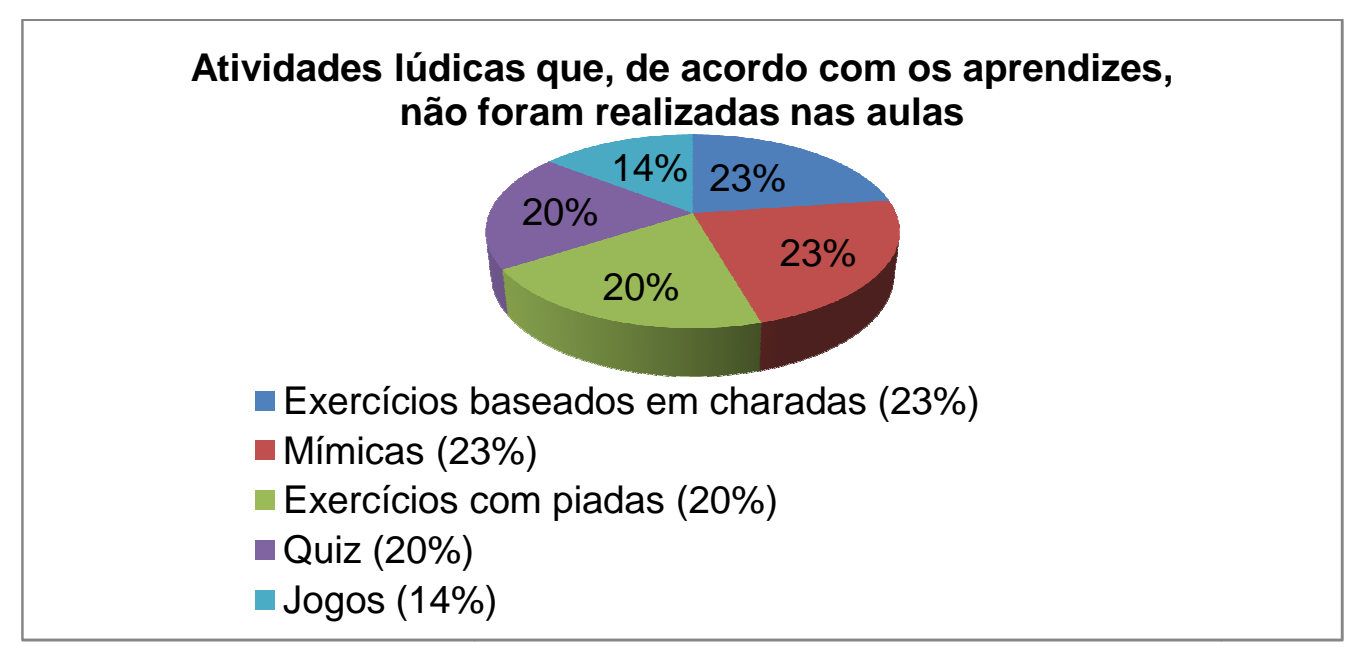

Gráfico 26 - Atividades lúdicas que, segundo os discentes, não foram usadas nas aulas

Como se vê no gráfico 26, as atividades lúdicas que, de acordo com os aprendizes, são menos utilizadas nas aulas de italiano LE são os exercícios baseados em charadas e as mímicas, por isso, tais atividades foram as mais assinaladas com a letra N. Já os jogos afirmam os estudantes - constituem a técnica lúdica mais aplicada em tais aulas. Talvez esse seja um dos motivos pelos quais os jogos são as técnicas lúdicas prediletas dos alunos do IC; ou, talvez, os jogos sejam as atividades lúdicas mais empregadas pelos docentes exatamente porque estes têm consciência de que essas técnicas são muito apreciadas pelos discentes.

\subsubsection{As atividades que os alunos do Italiano no Campus prefeririam que o professor utilizasse (mais) nas aulas}

Ao perguntarmos aos estudantes se havia alguma atividade que, na opinião deles, o professor/monitor deveria usar mais nas aulas de italiano LE, a maioria deles respondeu afirmativamente, como se pode observar no gráfico seguinte: 


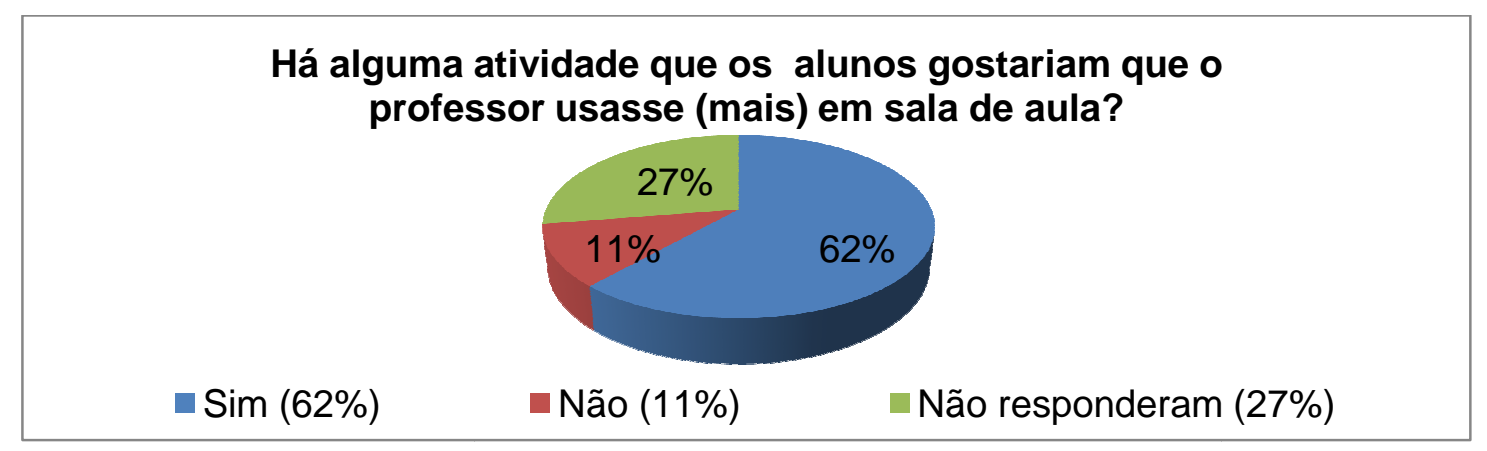

Gráfico 27 - De acordo com os aprendizes do IC, há alguma atividade que o professor deveria usar (mais) em sala de aula?

O grande percentual de respostas afirmativas indica, possivelmente, que, sob a ótica da maior parte dos discentes do IC, nós, professores de italiano, devemos diversificar as técnicas didáticas aplicadas na sala de aula. Vejamos, então, quais são as atividades que, de acordo com os aprendizes, deveríamos utilizar (mais).

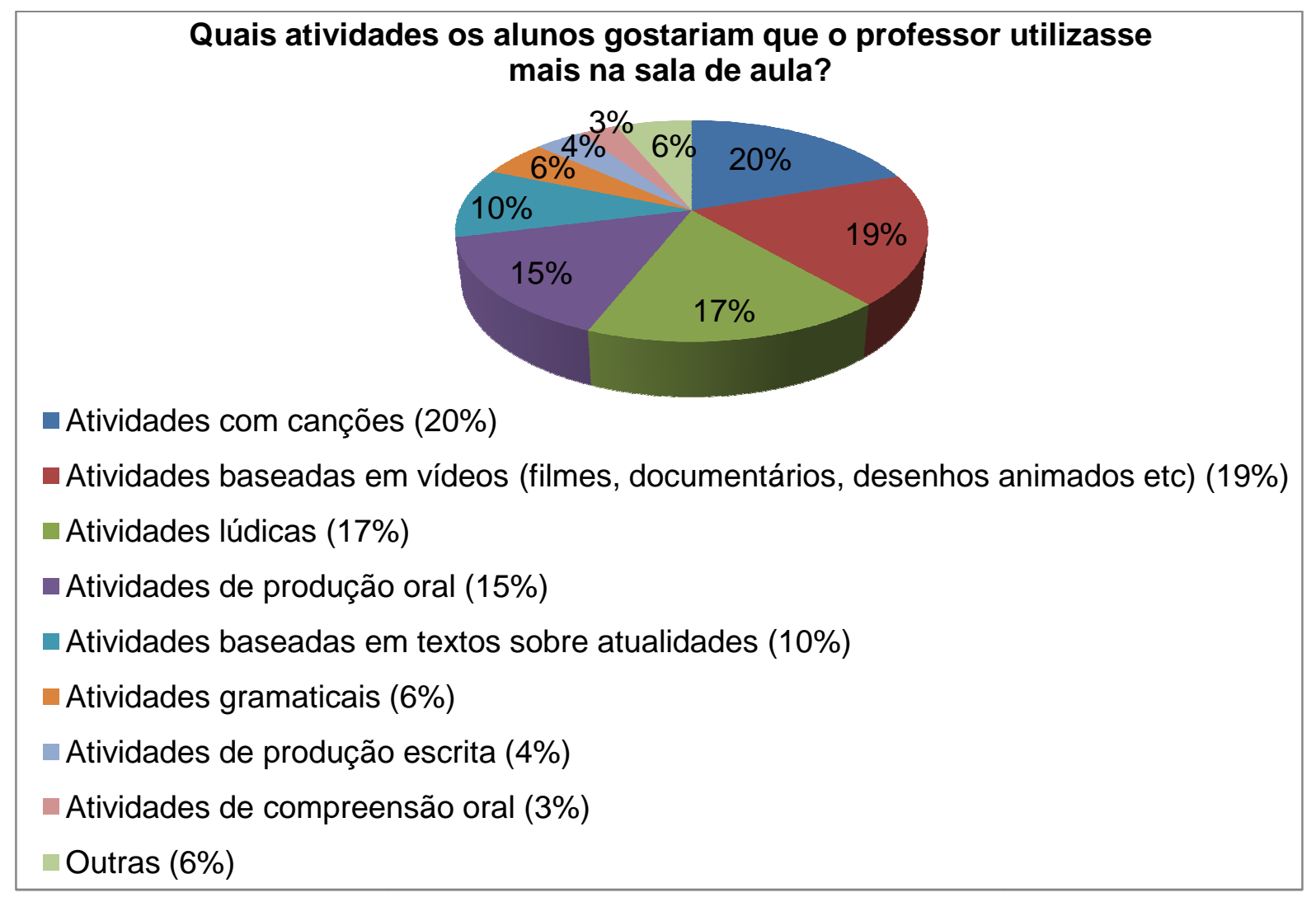

Gráfico 28 - Atividades que, segundo os discentes do IC, deveriam ser (mais) utilizadas nas aulas

As atividades que os estudantes citaram em primeiro lugar foram aquelas em que se utilizam canções; na verdade, como resposta a essa questão, 20\% deles escreveram 
exatamente "atividades com músicas", ou seja, eles afirmaram gostar, especificamente, de atividades elaboradas a partir desse material autêntico. A resposta de uma aluna de 20 anos do nível I esclarece-nos alguns dos motivos pelos quais os aprendizes gostariam que houvesse uma maior quantidade de atividades com canções no IC: "Sim. Atividades que envolvam músicas, pois estas ajudam a apreender mais vocabulário, bem como a pronúncia das palavras".

Em segundo lugar, foram mencionadas pelos alunos as atividades baseadas em vídeos. Alguns discentes especificaram o tipo de vídeo que eles preferem: dos 19\% dos aprendizes, 9\% disseram que gostariam que o professor usasse (mais) filmes nas aulas; $6 \%$ prefeririam documentários; $2 \%$, desenhos animados; e $2 \%$ dos alunos não mencionaram, especificamente, a categoria de vídeo que seria mais interessante para eles. Em terceiro lugar, foram citadas atividades lúdicas, que, de acordo com $17 \%$ dos estudantes, tornariam as aulas mais dinâmicas.

As atividades de produção oral foram as quartas mais mencionadas por eles. Dos $15 \%$ dos discentes que as escolheram, $7 \%$ afirmaram que, na opinião deles, deveriam ser utilizadas mais atividades de conversação direcionadas e mediadas pelo professor; isto é, parece que, para esse percentual de alunos, não interessam atividades de produção oral livre, mas sim, atividades em que eles possam expressar-se oralmente, tendo a mediação do docente.

Em quinto lugar, ficaram as atividades baseadas em textos referentes a atualidades: foi exatamente assim que $10 \%$ dos alunos escreveram. A maioria desses aprendizes não especificou a modalidade dos textos (oral ou escrita), nem o tipo de atividade em que poderiam ser usados esses materiais (atividades de compreensão escrita, de produção escrita, lúdicas etc) e nem mesmo o gênero textual (artigos científicos, entrevistas, editoriais etc). Desses $10 \%$, apenas $3 \%$ explicitaram os quesitos a que acabamos de nos referir, citando atividades de leitura e artigos de jornal e revista, ou seja, esse pequeno percentual explicitou uma categoria de atividade e um gênero de texto contido em dois suportes diferentes.

A resposta de uma aluna de 24 anos do nível VIII é bastante esclarecedora quanto às razões pelas quais os aprendizes gostariam de trabalhar com textos relacionados a atualidades: "Leituras de textos mais atuais com informações cotidianas atuais, históricas ou culturais; e vídeos com documentários e/ou publicidades, pois assim ficaria mais próximo de nossa realidade. Portanto, mais fácil de aprender". 
Note-se que a estudante não mencionou somente um tipo de atividade. Isso foi frequente em muitas das respostas, isto é, vários discentes (46\%) citaram duas ou mais atividades que, a seu ver, deveriam ser (mais) usadas na sala de aula; é o que se vê nestas transcrições:

- "Trechos de filmes, músicas. Porque apenas se concentrar no livro de apoio é tedioso" (24 anos, nível VII).

- "Sim. Ouvir e preencher músicas, assistir a vídeos atuais e leitura de textos atuais para me sentir mais 'inserida na Itália'” (31 anos, nível II).

- "Exercícios com música ou filme, pois aproxima mais a cultura e estreita a relação com a língua" (21 anos, nível I).

- "Textos literários e atividades de jogos, porque gosto de literatura e acho que jogos enfatizam o estudo e ajudam na memorização" (19 anos, nível I).

- "Sim. Uso de alguns materiais autênticos como: telejornais, filmes, propagandas. Através desses materiais, é possível obter uma noção mais contextualizada da cultura italiana" (22 anos, nível VII).

As atividades citadas em sexto lugar pelos alunos foram as gramaticais. Possivelmente, um dos motivos que os levaram a citá-las está relacionado ao livro didático adotado no curso, como se vê na seguinte resposta de um aprendiz de 22 anos do nível II: "[Seria interessante que houvesse] Mais atividades gramaticais, o livro tem poucos exercícios".

Em sétimo lugar, foram mencionadas pelos aprendizes as atividades de produção escrita; em oitavo, as de compreensão oral; e, por fim, no item "outras", incluem-se atividades lexicais, atividades com fotografias, com receitas e em grupos.

\subsection{Opiniões dos alunos quanto ao livro didático adotado no IC}

No capítulo 1, apresentamos algumas reflexões teóricas sobre o principal representante da categoria dos materiais didáticos, isto é, o livro didático. No presente capítulo, apresentaremos as opiniões de quem o utiliza, na prática, como instrumento de aprendizagem: os estudantes.

Trabalhamos no Italiano no Campus de março de 2009 a abril de 2011, e, antes mesmo de começarmos a trabalhar nesse curso, o livro didático adotado era o Linea 
diretta. No segundo semestre de 2010, começou-se a cogitar a ideia de substituir esse livro, no entanto, essa mudança será implementada gradativamente, o que quer dizer que o manual didático em questão ainda é utilizado no IC.

As respostas dos discentes do Italiano no Campus mostram-nos que a maioria deles gosta do manual didático:

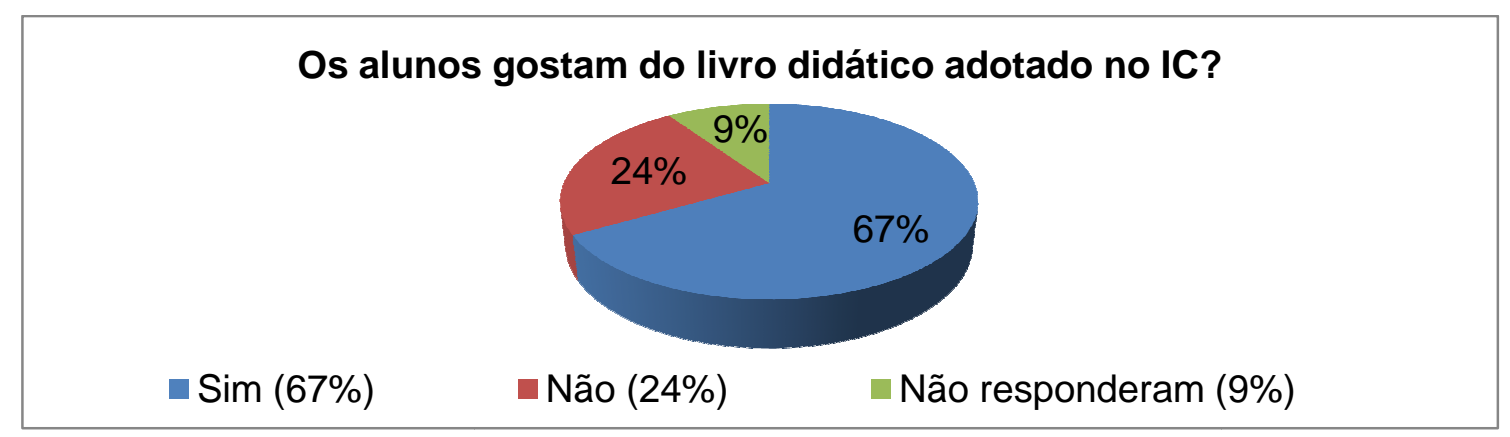

Gráfico 29 - Os estudantes do IC gostam do livro Linea diretta?

Visto que a maior parte dos aprendizes do IC diz gostar do livro didático adotado no curso, vejamos quais são as opiniões deles quanto a esse material:

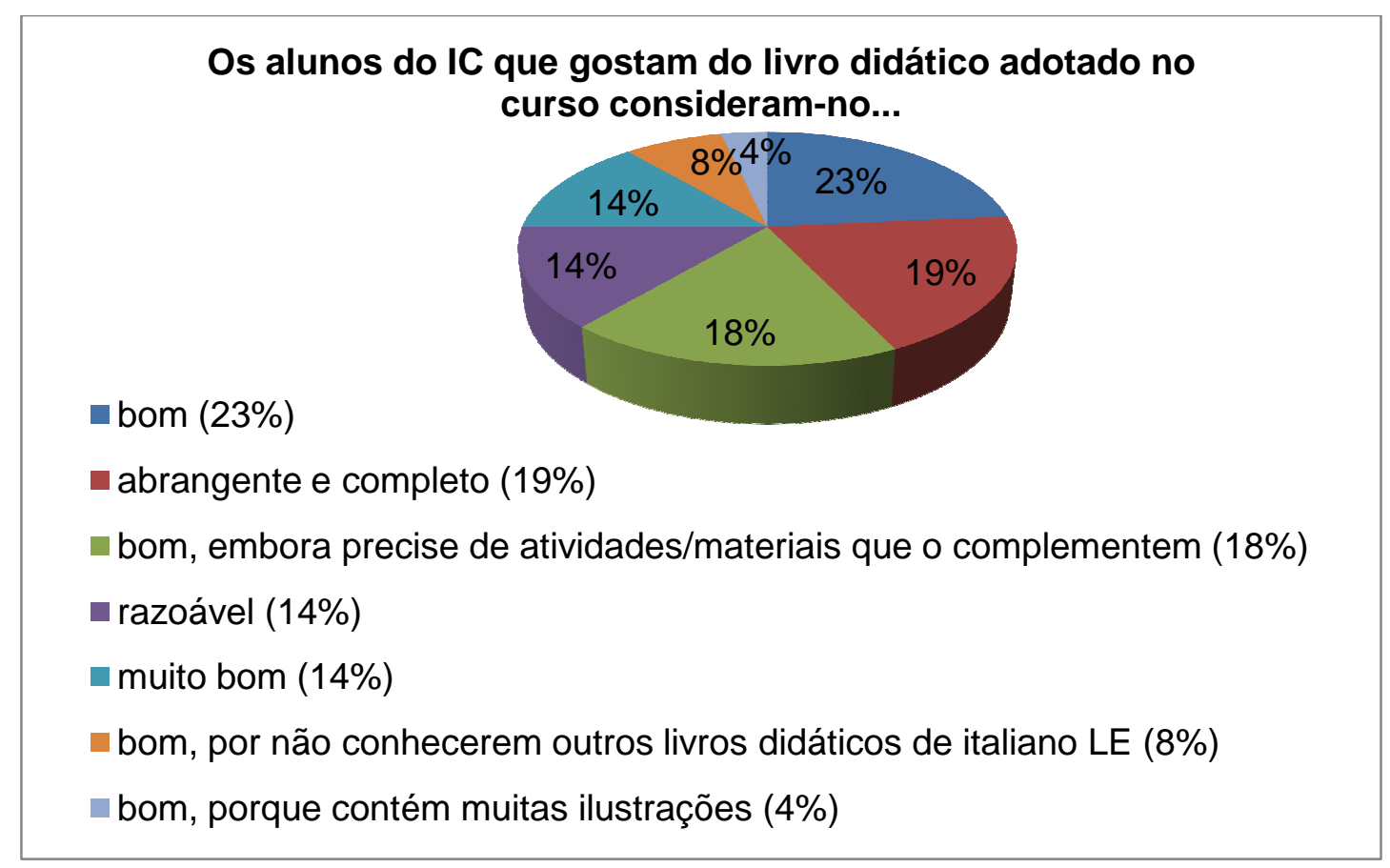

Gráfico 30 - Opiniões favoráveis dos alunos quanto ao LD adotado no Italiano no Campus

Boa parte dos discentes (quarenta e seis) respondeu, simplesmente, "o livro é bom", sem, no entanto, explicar o porquê de tal parecer. Apenas uma aluna de 39 anos do nível I disse explicitamente o motivo que a faz ter essa opinião: "Achei bom, 
principalmente porque os diálogos (áudio) são naturais, velocidade normal (não muito lentos, muito 'encenados')".

De fato, os diálogos contidos no $\mathrm{CD}$ que acompanha o livro são textos orais autentificados, que, segundo Franzoni (1992), consistem em textos elaborados ad hoc, mas que têm o intuito de assemelhar-se aos textos produzidos em situações reais de comunicação.

Ao examinar tais diálogos com atenção, pode-se notar que eles são produzidos por falantes nativos de italiano, e que houve, por parte dos autores desse manual didático, uma preocupação em autentificar os textos orais. Isso é percebido inclusive pelos próprios aprendizes: até mesmo a discente do nível I, em sua resposta, ressaltou a velocidade natural dos diálogos.

Todavia, esses textos orais contêm, em geral, exatamente as estruturas linguísticas a serem apresentadas aos estudantes em cada unidade didática do livro. Na verdade, a maioria dos livros didáticos de italiano para estrangeiros possui essa característica.

Trinta e oito aprendizes afirmaram considerar Linea diretta um material abrangente e completo; $18 \%$ acham que esse LD, embora seja bom, requer complementos, como outros materiais e atividades, que devem ser selecionados e/ou elaborados pelo professor; é o que se vê nas respostas seguintes:

- "O livro em si é bom, porém o professor deve complementar com outros materiais, para reforçar o aprendizado" (45 anos, nível VII).

- "Gosto [do livro]! Mas, o acréscimo de exercícios apostilados de outros livros, jornais, revistas etc (xerox) trazidos pela professora é muito útil”" (43 anos, nível II).

Os alunos que consideram o LD razoável (14\%), em sua maioria, não explicitaram as razões de tal parecer. Pouquíssimos desses estudantes (2\%), entretanto, justificaram esse tipo de resposta; vejamos a transcrição de uma delas: "Todo livro didático não é completo. Considero esse razoável. Mas, acredito que sejam necessárias atividades extras. Somente ele não dá conta" (28 anos, nível VI).

Tal resposta evidencia aquilo que quase todos os teóricos da área da pedagogia de línguas dizem: não há livro didático completo e, portanto, o professor não deve restringirse ao uso desse material.

Os discentes (14\%) que consideram muito bom o manual didático não explicitaram os motivos de tal opinião. Por sua vez, os aprendizes (8\%) que afirmam gostar do livro por não conhecerem outros livros didáticos de italiano LE disseram-no claramente em suas respostas. 
Por fim, na opinião de $4 \%$ dos alunos, Linea diretta é bom por conta de suas ilustrações; é o que se vê nesta resposta: "O livro é bom pois tem boas ilustrações, mas acho que o professor não pode utilizar unicamente este meio" (78 anos, nível VI). Notese, mais uma vez, a declaração de que o docente não pode usar, em suas aulas, unicamente esse material.

Vejamos, agora, o que pensam sobre o livro didático adotado no IC os aprendizes que afirmaram não gostar do LD.

\section{Os alunos do IC que não gostam do livro didático adotado no curso consideram-no...}

- repetitivo e chato (47\%)

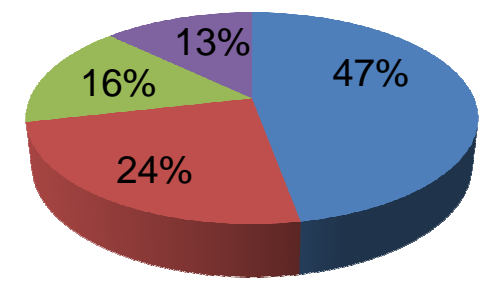

- ruim, porque contém poucas explicações gramaticais (24\%)

ruim, porque contém poucos exercícios (16\%)

- ruim, porque apresenta poucos elementos referentes à cultura e ao cotidiano da Itália (13\%)

Gráfico 31 - Opiniões desfavoráveis dos aprendizes quanto ao LD adotado no Italiano no Campus

Como vimos no gráfico 29, 24\% dos discentes afirmaram não gostar do Linea diretta. Trinta e três desses alunos disseram considerá-lo repetitivo e/ou chato. Abaixo, transcrevemos três respostas que ilustram esse parecer:

- "Não gosto do livro utilizado, pois os exercícios são muito quadradinhos, a estrutura se repete em todos os estágios" (30 anos, nível V).

- "É uma proposta que privilegia a repetição de estruturas e não a criatividade da língua" (64 anos, nível VI).

- "Não gosto. É um material um pouco sem graça e alguns exercícios são realmente chatos" (42 anos, nível VIII).

Dezessete estudantes consideram o LD ruim, porque, de acordo com eles, esse material contém poucas explicações gramaticais. Onze alunos consideram-no ruim por acharem insuficiente a quantidade de exercícios contida no livro. 
Por sua vez, conforme o parecer de $13 \%$ dos discentes, Linea diretta é ruim, porque apresenta poucos aspectos concernentes à cultura e ao cotidiano da Itália. Transcrevemos, a seguir, duas respostas em que os alunos expressam essa opinião:

- "Acho que poderia ser mais moderno, com coisas mais atuais, que realmente são usadas na Itália e não só a mesma estrutura página após página” (28 anos, nível VII).

- "Não. Linea diretta possui alguns diálogos e temas ultrapassados e além disso visualmente não chama atenção. Os exercícios são muito previsíveis e as situações de conversação fechadas. Precisava de mais elementos da cultura” (22 anos, nível VII).

Para concluir a parte de nossa dissertação em que apresentamos as opiniões dos aprendizes do Italiano no Campus quanto ao livro adotado no curso, citamos a resposta de uma aluna de 24 do nível VIII que resume o que pesquisadores e alguns estudantes declaram sobre o papel do manual didático em um curso de língua estrangeira: "Na verdade não gosto muito de livros didáticos, pois acredito que eles formatam e limitam o trabalho do professor, principalmente se forem utilizados como única ferramenta ou se seu uso total é obrigatório". Concordamos com essa opinião e, por esse motivo, escolhemos investigar e propor alternativas para não nos restringirmos ao conteúdo apresentado pelo livro didático de italiano LE.

\subsection{Os materiais de que os estudantes do Italiano no Campus mais gostam}

Como vimos, o percentual de alunos que gosta do livro didático adotado no IC corresponde a $67 \%$. Na questão cujo objetivo consistia em identificar os materiais preferidos pelos aprendizes, o LD foi o instrumento de ensino-aprendizagem mais votado, como se vê no gráfico seguinte: 


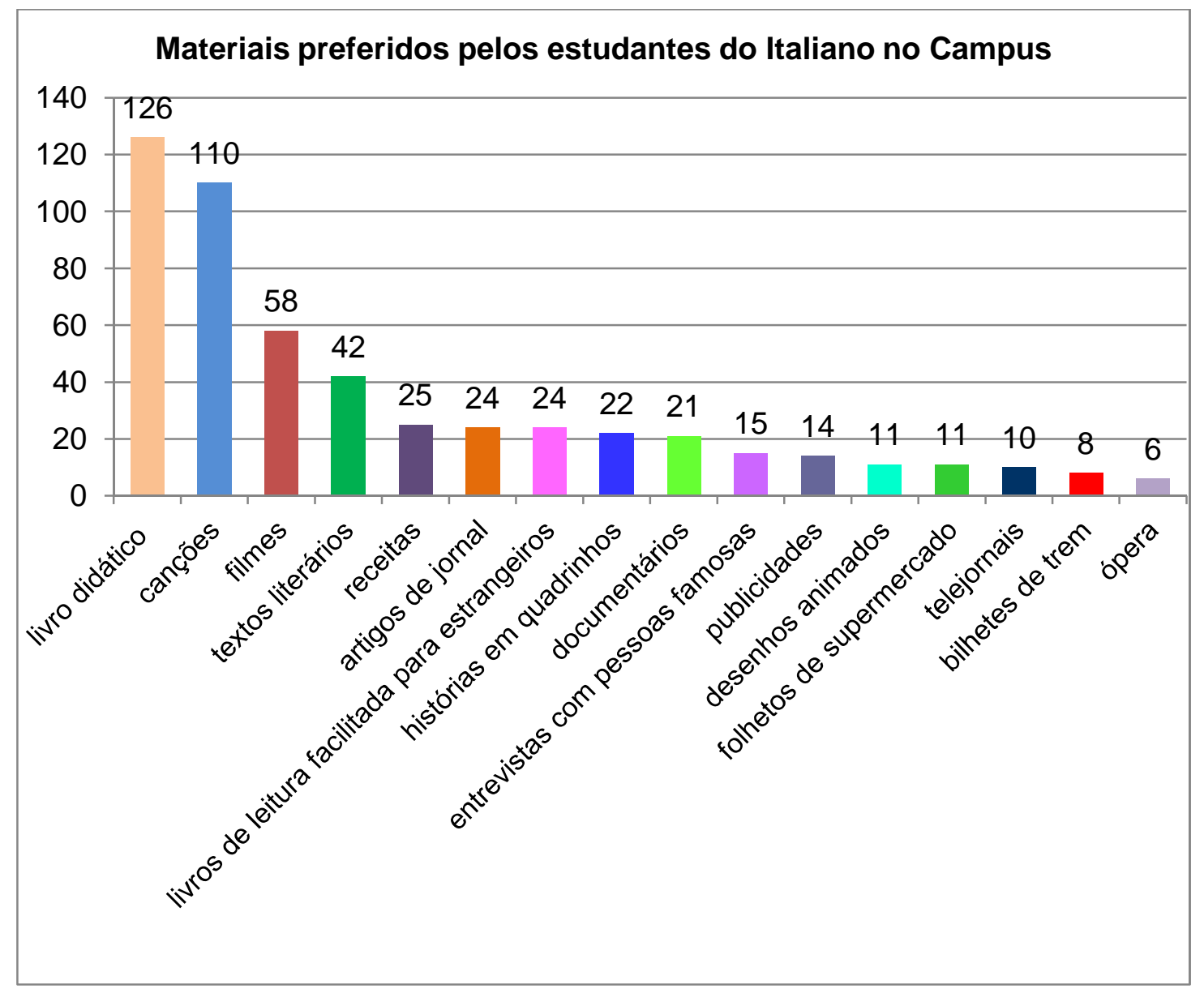

Gráfico 32 - Materiais assinalados como primeira opção pelos alunos do IC

Nessa questão, havia dezessete itens, dentre os quais os discentes deveriam escolher os seus preferidos. Depois disso, os estudantes deveriam justificar suas três primeiras escolhas, estabelecendo uma classificação dos materiais; ou seja, nossa ideia era a de que os alunos selecionassem os três materiais de sua preferência e explicitassem quais destes seriam o primeiro, o segundo e o terceiro materiais de que mais gostam. Para fazer uma classificação completa, se quisessem, os estudantes poderiam usar os numerais de 1 a 17 , visto que, na questão 13, havia dezessete itens a serem classificados.

No entanto, como muitos discentes (72\%) assinalaram, com o numeral 1, dois ou mais materiais, parece-nos que esses aprendizes gostam igualmente desses instrumentos de ensino-aprendizagem e não lhes agrada muito a ideia de classificá-los.

Por isso, no gráfico 32, a soma da quantidade de respostas é superior ao número total de questionários respondidos. Doze alunos invalidaram suas respostas, pois em vez de usarem numerais para estabelecer uma classificação, apenas assinalaram alguns materiais com um $X$. 
Em tal gráfico, colocamos os materiais que os estudantes assinalaram como primeira opção e não inserimos o item "bulas de medicamentos", que não foi escolhido como primeira opção por nenhum aluno.

A análise desse gráfico permite-nos afirmar que o representante clássico dos materiais didáticos é o preferido pelos estudantes. Os outros materiais, pertencentes à categoria dos materiais autênticos, estão em segundo lugar na classificação estabelecida pelos discentes.

Em tal categoria, mais uma vez, reafirma-se a preferência dos alunos pela música. Por sua vez, o material autêntico menos escolhido como primeira opção pelos discentes é a ópera, provavelmente porque esta não é usada (ou é usada raramente) nas aulas do IC.

Vejamos, abaixo, os motivos pelos quais muitos estudantes gostam tanto do LD, o material favorito de boa parte dos discentes:

- "O livro didático é a primeira ferramenta estruturada para o conhecimento da língua" (25 anos, nível III).

- "Livro didático: mal necessário" (56 anos, nível VII).

- "O livro didático é a referência, a certeza de que se aprende” (61 anos, nível I).

- "Gosto do livro, e a aula é basicamente limitada ao livro didático" (46 anos, nível II).

- "Só utilizamos até o momento o livro didático, mas acho interessante usar materiais do cotidiano, como entrevistas, documentários e artigos" (39 anos, nível I).

Pelas respostas, vê-se que, para os aprendizes cujo material preferido é o LD, ele é um instrumento que lhes possibilita o conhecimento da língua-alvo; é uma referência, que, como afirma Mezzadri (2003) dá segurança aos alunos. Tal segurança é evidente, sobretudo, na terceira resposta: a aluna de 61 anos do nível I parece afirmar que o manual didático é a garantia de aprendizagem da LE. Na segunda resposta, parece-nos que a discente considera que o LD seja algo ruim, mas indispensável nas aulas de língua estrangeira.

Nas duas últimas respostas acima mencionadas, parece-nos que o motivo pelo qual os aprendizes citam o livro didático como seu material predileto está relacionado ao fato de o LD ser o único material empregado na sala de aula. Contudo, a estudante de 39 anos do nível I parece expressar, em sua resposta, a vontade de que, nas aulas, sejam usados, além do manual didático, alguns gêneros textuais como a entrevista, o documentário e o artigo, materiais autênticos presentes no cotidiano. 
Vejamos, agora, algumas razões pelas quais os materiais autênticos são preferidos por muitos estudantes:

- "Os filmes e canções me agradam muito e sua utilização para o aprendizado da língua é motivante" (25 anos, nível III).

- "Nos desenhos animados, você aprende se divertindo. Nos filmes e nos desenhos, a imagem facilita a contextualização e o entendimento" (26 anos, nível II).

- "Histórias em quadrinhos trazem humor, o que é muito bom, é universal" (62 anos, nível VI).

- "Acredito que documentários, artigos de jornais e textos literários são ferramentas que, quando bem exploradas, podem possibilitar a aprendizagem da língua de forma mais prazerosa, com o mesmo rigor em termos de gramática, vocabulário etc, mas sem a formatação limitada do livro didático" (24 anos, nível VIII).

- “O que mais gosto são os filmes (ficção e documentários), as músicas e as receitas e os textos literários. Como eu disse antes porque entendo que conhecendo a cultura, se aprende a língua com mais facilidade" (60 anos, nível I).

A esse ponto, considerando o conjunto de respostas obtidas até agora, corroboradas por essas últimas declarações, podemos afirmar que, para os aprendizes, o trabalho com materiais autênticos pode ser uma fonte de motivação, diversão, prazer e conhecimentos culturais.

Nas respostas acima, os alunos afirmam que filmes, canções, desenhos animados, histórias em quadrinhos, documentários, artigos de jornal, textos literários e receitas tornam motivante a aprendizagem da LE, favorecem a aprendizagem gramatical e lexical e veiculam a cultura-alvo. De fato, como salienta Mezzadri (2003), a variedade de materiais e de atividades torna as aulas prazerosas e promove a motivação dos aprendizes.

O gráfico seguinte parece mostrar a existência de uma possível relação entre os materiais empregados (ou não) nas aulas do Italiano no Campus e as preferências dos estudantes no que concerne a tais instrumentos de ensino-aprendizagem. 


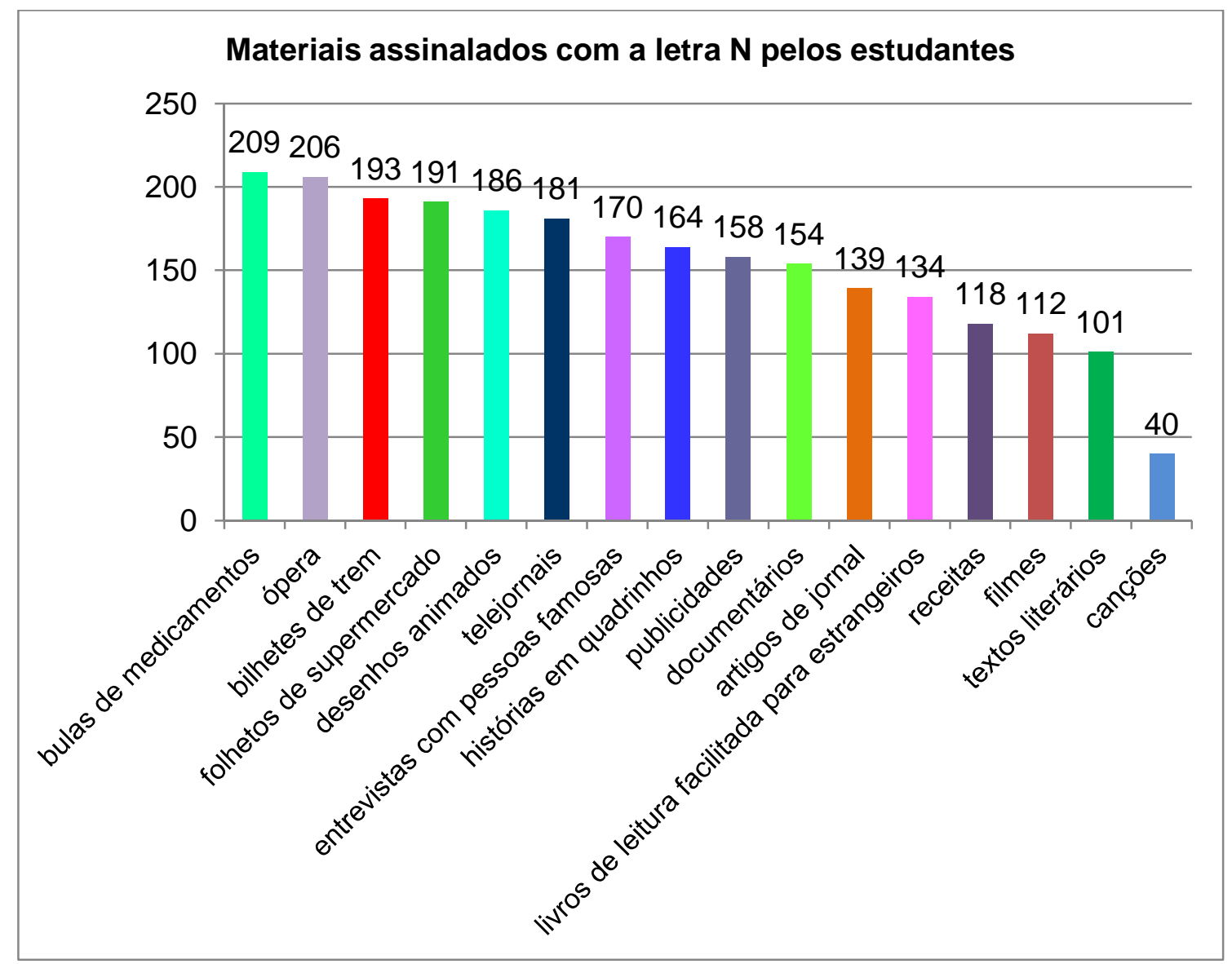

Gráfico 33 - Materiais que, segundo os alunos do IC, não foram usados nas aulas

Observando e comparando os gráficos 32 e 33, podemos dizer que essa relação, talvez, seja a seguinte: os materiais de que os alunos mais gostam parecem ser exatamente os utilizados com maior frequência nas aulas de italiano LE, e os materiais de que os discentes menos gostam são, em sua maioria, aqueles cujo uso é raro (ou inexistente) em tais aulas. Talvez, seja por esse motivo que o livro didático é o material predileto dos alunos, e a ópera, o material de que eles menos gostam.

Essa constatação pode estar relacionada, de certo modo, aos interesses dos alunos, no sentido de que, raramente, os estudantes se interessam por aquilo que não conhecem; ou seja, um material que não é (ou não costuma ser) empregado nas aulas, dificilmente interessará aos aprendizes.

Como vimos no capítulo 1, Bonvino (2008) afirma que, no tocante aos conteúdos, os interesses dos discentes podem variar em função da rede de conhecimentos que os aprendizes construíram até aquele momento.

Desse modo, uma interpretação possível para os dois últimos gráficos é a de que, quanto aos materiais usados nas aulas de italiano LE (e, talvez, de outras línguas 
estrangeiras), os interesses dos alunos podem variar em função da maior ou menor familiaridade que os discentes têm com esses materiais.

A resposta transcrita a seguir pode confirmar tal relação: "Gosto do livro, das canções, dos textos literários e dos documentários talvez porque só usamos esses materiais no transcorrer do curso" (54 anos, nível III).

Ao responder a questão referente aos materiais de sua preferência, alguns estudantes fizeram, de certo modo, reivindicações que antecipam as respostas à pergunta $\mathrm{n}^{\mathrm{o}} 14$; é o que se vê abaixo:

- "Os materiais que eu mais gostaria de ter nas aulas são: desenhos animados, folhetos de supermercado, bulas e histórias em quadrinhos" (54 anos, nível II).

- "Deveriam ser usados, além do livro didático, pelo menos os folhetos de supermercado, os artigos de jornal, as receitas e os documentários" (59 anos, nível I).

- "Gostaria demais que tivéssemos atualidades em artigos de jornal, documentários e entrevistas. Penso também em história em quadrinhos" (47 anos, nível VI).

Note-se que todos os materiais citados pelos aprendizes são materiais autênticos, o que parece evidenciar um desejo dos alunos: o desejo de que, nas aulas de italiano LE, não sejam utilizados apenas materiais didáticos.

4.5.1. Os materiais que o professor deveria utilizar (mais) nas aulas de italiano: as opiniões dos discentes

A maioria dos estudantes afirma que, a seu ver, há materiais que o professor deveria empregar (mais) na sala de aula. É o que se vê no gráfico que segue:

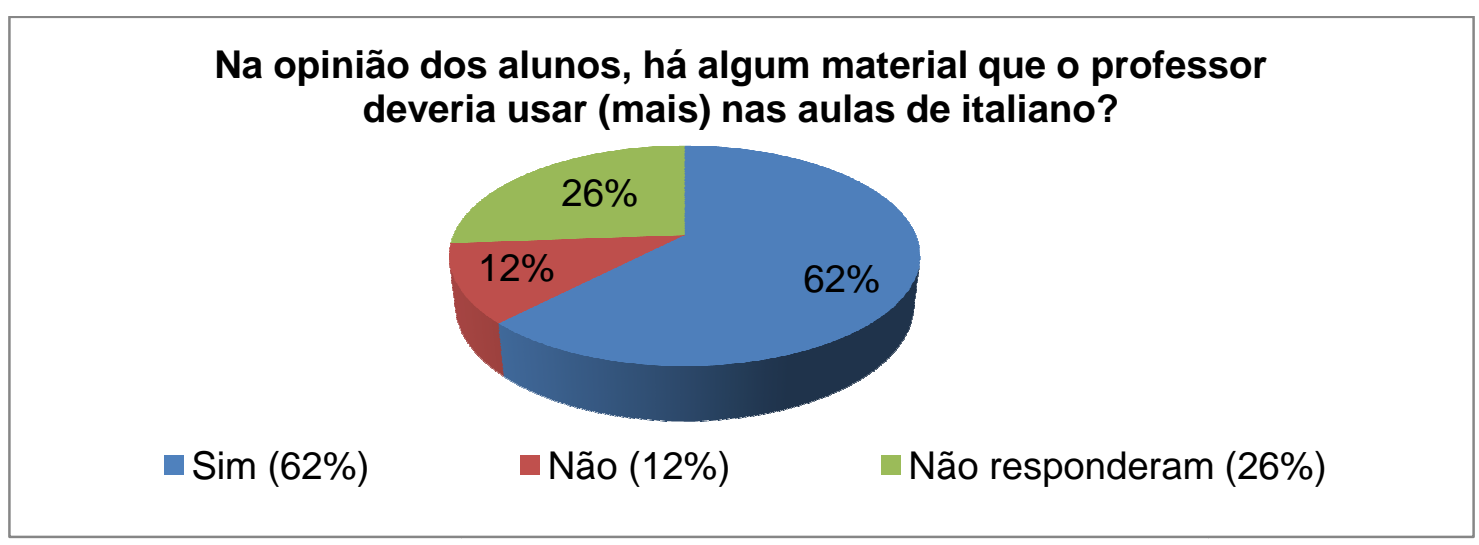

Gráfico 34 - Segundo os alunos do IC, há algum material que o professor/monitor deveria utilizar (mais) na sala de aula? 
Dos $62 \%$ de discentes que responderam afirmativamente a essa questão, apenas 3\% não mencionaram quais materiais eles gostariam que o professor usasse (mais) nas aulas de italiano LE; já os demais 59\% citaram-nos. É o que se vê no gráfico seguinte:

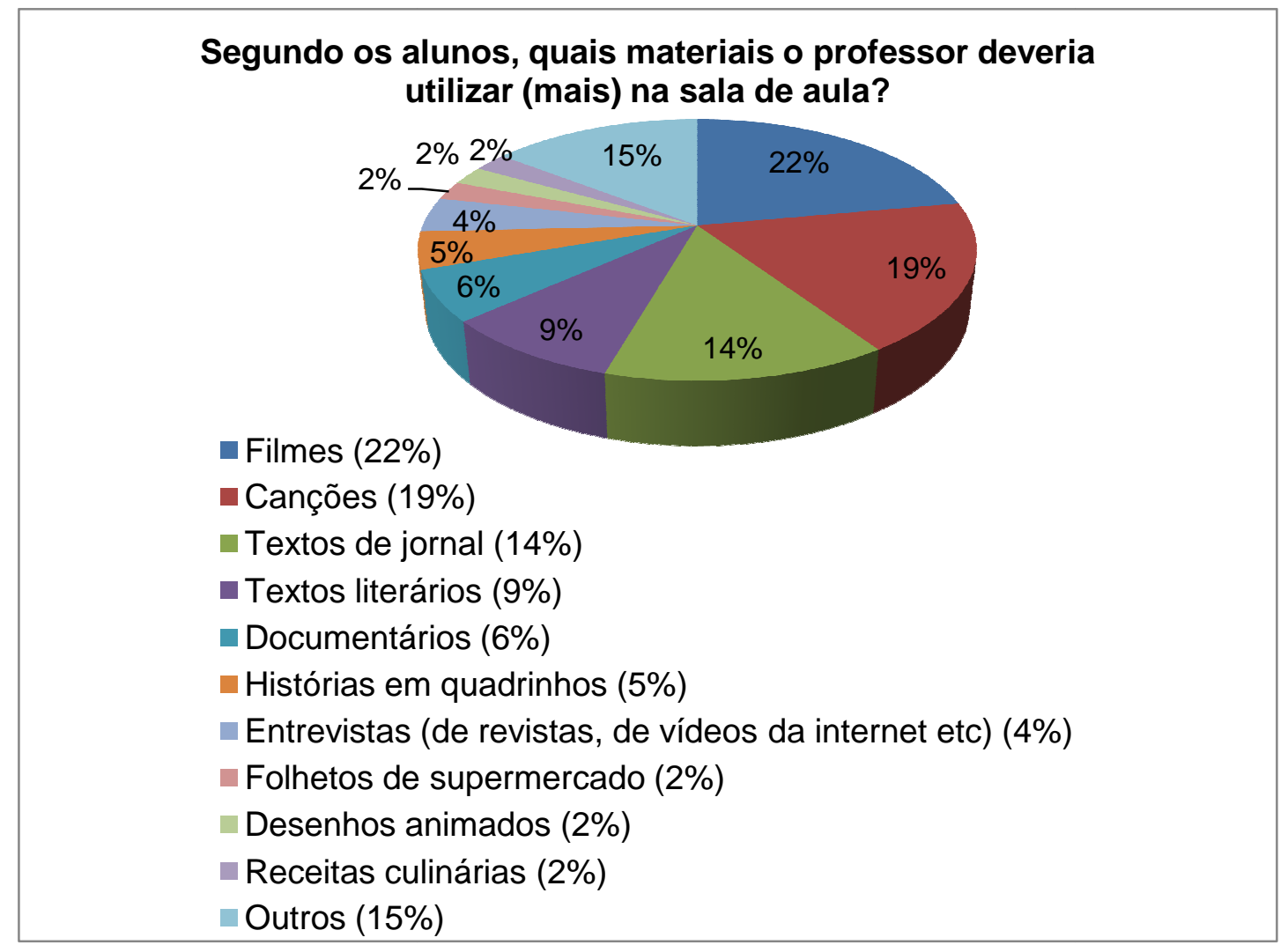

Gráfico 35 - Materiais que, de acordo com os aprendizes, deveriam ser (mais) usados nas aulas do Italiano no Campus

Como se pode observar no gráfico 35 , os materiais mais citados pelos estudantes foram os filmes, seguidos das canções. Esses materiais são, como mostra o gráfico 32, respectivamente, o terceiro e o segundo preferidos pelos discentes. No item "outros", incluem-se as fotografias, os telejornais, as publicidades, as propagandas, as óperas, os catálogos turísticos, os bilhetes de trem e de ônibus, os bate-papos on-line e as listas de verbos. Cada um desses materiais foi citado por menos de sete alunos.

Note-se que, nesse item, o único material didático mencionado foi a lista de verbos, ou seja, os demais materiais que, segundo os aprendizes, deveriam ser (mais) utilizados nas aulas do IC são todos materiais autênticos. Aliás, é importante notar que, no gráfico 35, encontram-se apenas textos autênticos, o que pode significar que, para os estudantes, seria necessário que o professor fizesse um uso mais frequente dessa categoria de material. 
O principal motivo pelo qual os alunos gostariam de ter um maior contato com os materiais autênticos diz respeito ao fato de esses textos veicularem a língua em uso, a língua utilizada em situações reais de comunicação, a língua usada na vida cotidiana. As respostas transcritas a seguir ilustram claramente esse motivo:

- "Materiais diversos que se aproximassem mais da vida real e não ficassem na ficção artificial do livro" (24 anos, nível VIII).

- "Uso de materiais mais atuais da vida cotidiana, como: folhetos de supermercado, artigos de jornal..." (50 anos, nível VIII).

- "Músicas, telejornais, publicidades etc, pois vemos certas estruturas sendo usadas na 'vida real'” (18 anos, nível IV).

- "Se tivéssemos acesso aos quadrinhos, seria interessante, pois esse gênero apresenta a língua do dia a dia" (60 anos, nível VII).

Para $12 \%$ dos aprendizes, no entanto, como se vê no gráfico 34 , não há materiais que o professor deveria empregar (mais) nas aulas de italiano LE. Desse percentual, apenas dois estudantes explicaram o porquê de tal opinião; transcrevemos, abaixo, suas respostas:

- "Não. Acho que as aulas já estão boas com os materiais que usamos" (38 anos, nível IV).

- "Não, pois cada professor tem o seu próprio estilo e deve desfrutar de liberdade para exercê-lo, não se prendendo a excessos de padronização”. (24 anos, nível III).

Ao usar a palavra "estilo" em sua resposta, o discente do nível III parece referir-se à abordagem de ensinar do professor. Assim, para esse estudante, provavelmente, o uso dos materiais na sala de aula está relacionado à abordagem do docente, que, segundo tal aprendiz, deve ter autonomia para colocá-la em prática.

Quanto à defesa da autonomia do professor, o comentário feito pelo aluno do nível III vai ao encontro dos postulados de Kumaravadivelu (2006), autor que sustenta a ideia de que o professor deve saber agir de maneira autônoma, sem ficar preso a imposições, sejam elas institucionais, curriculares ou referentes ao livro didático.

\subsection{Os materiais utilizados nas aulas do Italiano no Campus - as opiniões dos professores}


Já vimos as opiniões dos alunos quanto às atividades e aos materiais utilizados nas aulas do Italiano no Campus, agora, para finalizar este capítulo, veremos o que dizem os professores do IC a respeito desses elementos importantes no processo de ensinoaprendizagem da língua-alvo.

Para conhecer as opiniões dos professores, fizemos-lhes quatro questões e enviamos-lhes por e-mail no final de abril de 2012, mês em que concluímos a análise das respostas dos aprendizes. Solicitamos aos docentes que nos respondessem até o dia 15 de maio de 2012. As perguntas feitas foram estas:

1. Qual é a sua idade?

2. Há quanto tempo você dá aulas de italiano?

3. Qual (quais) material (materiais) você costuma usar nas aulas do Italiano no Campus?

4. Por que você usa esse(s) material (materiais)?

Com essas perguntas, nossos objetivos consistiam, respectivamente, em saber: a faixa etária dos docentes do IC; se eles têm muito tempo de experiência no âmbito do ensino do italiano LE, ou se são professores iniciantes; quais os materiais autênticos e didáticos mais usados em suas aulas; os motivos pelos quais os professores utilizam esses materiais.

As perguntas foram enviadas aos doze monitores do IC, entretanto obtivemos respostas de apenas oito. A seguir, faremos uma breve análise de tais respostas, procurando relacioná-las às dos aprendizes.

No tocante à primeira questão, com bases nas respostas dos oito docentes, podemos dizer que a faixa etária deles varia entre 24 e 40 anos. Em relação à segunda, é possível afirmar que o professor mais experiente do IC dá aulas de italiano há oito anos; já o menos experiente ensina a língua italiana há apenas um ano.

No que concerne à terceira pergunta, os docentes afirmaram empregar vários materiais autênticos e didáticos. O gráfico a seguir mostra os materiais mencionados pelos professores: 


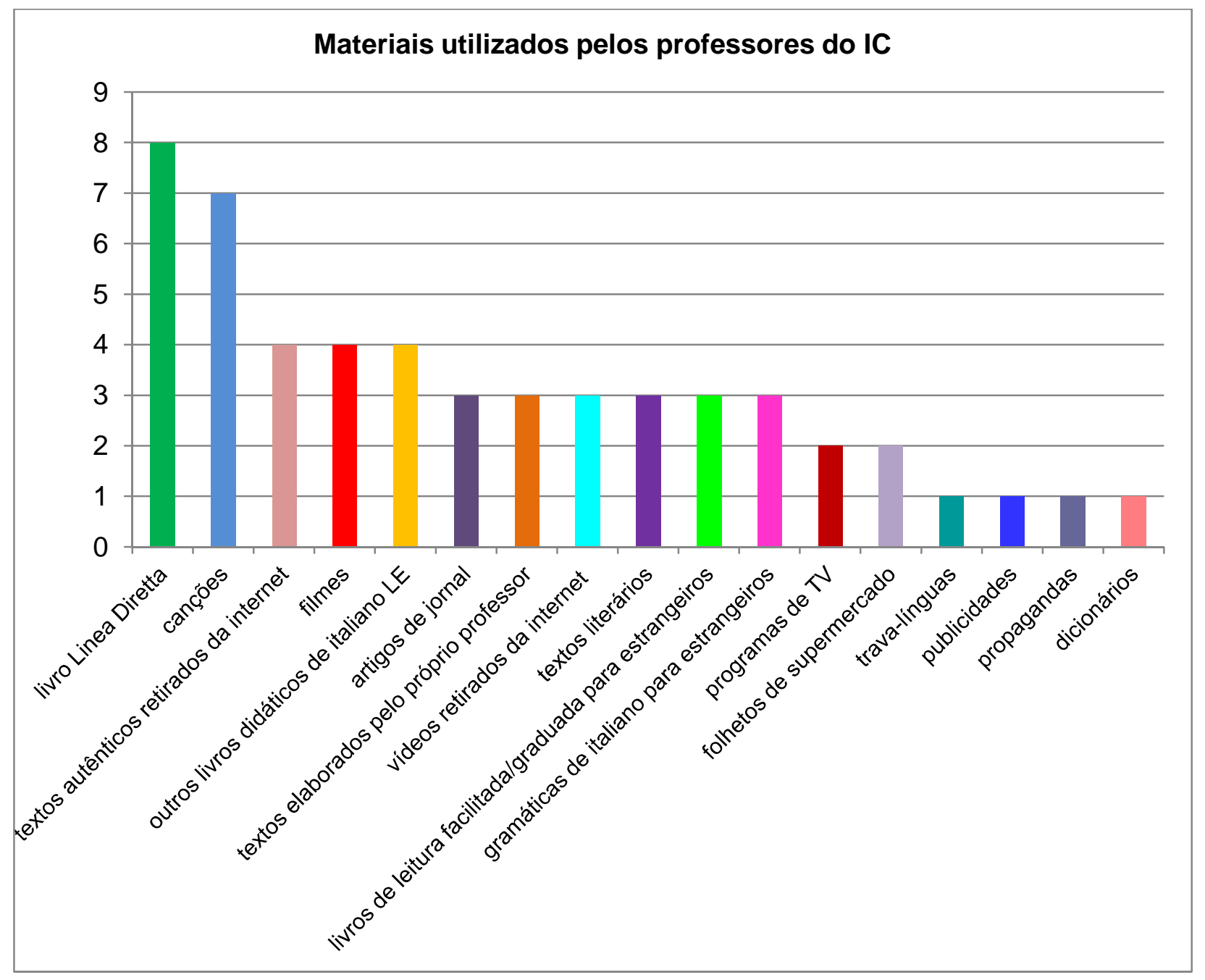

Gráfico 36 - Quais materiais os professores costumam utilizar nas aulas do Italiano no Campus?

O livro didático e as canções são, respectivamente, o primeiro e o segundo materiais preferidos pelos discentes e, no gráfico acima, são exatamente esses os materiais mais citados pelos professores do IC, o que parece corroborar nossa hipótese de que os materiais de que os alunos mais gostam são, geralmente, aqueles que os docentes mais utilizam nas aulas.

Em terceiro lugar, mencionados por quatro dos oito monitores, aparecem os textos autênticos retirados da internet, os filmes e outros livros didáticos de italiano LE. Entre esses livros, os docentes citaram os seguintes: Nuovo Progetto Italiano, Chiaro! e Qui Italia.

Quanto à pergunta $\mathrm{n}^{\circ}$ 4, a maioria dos professores não especificou, separadamente, os motivos que os levam a usar cada um dos materiais citados. Por isso, comentaremos as 
respostas dos docentes de modo bastante amplo. Vejamos quais são as justificativas apresentadas por eles para a utilização dos materiais supracitados:

- "Quanto aos materiais que uso nas aulas: além do livro Linea Diretta, gosto de trazer textos autênticos e exercícios que eu mesma preparo de acordo com as necessidades dos alunos" (docente de italiano LE há um ano ${ }^{66}$ ).

- "O uso dos materiais citados é feito para complementar e ampliar os conteúdos tratados no livro base do curso" (um ano e meio).

- "Uso esses materiais porque é importante que eles [os alunos] vejam um pouco do real, não somente as repetições contidas no Linea Diretta, e sei que gostam porque é um contato mais direto com a cultura italiana, dependendo da atividade até eu me sinto na Itália!" (três anos).

- "Uso as canções, os textos literários e os contos por acreditar que os alunos, tendo contato com esses materiais na sala de aula, passam a procurar outros recursos para aprenderem a língua italiana; acredito que se sintam mais motivados a estudarem sozinhos e a buscarem mais informações não só sobre a língua italiana mas, sobretudo, sobre a cultura e a sociedade italianas" (três anos e meio).

- "Usava ${ }^{67}$ esses materiais por acreditar que, primeiro, o Linea Diretta não dispunha de todas as atividades necessárias para que o aluno possa efetivamente adquirir língua se pensarmos numa abordagem comunicativa, segundo que as músicas e os filmes trabalham o lúdico (...)” (quatro anos).

- "Utilizo os materiais citados porque acredito que as aulas precisem ir além do manual didático, assim, escolho materiais que possam enriquecê-las ainda mais e que proporcionem um contato maior com a cultura e a língua italianas por parte dos alunos" (seis anos).

- "O livro didático Linea diretta, porque é previsto pelo programa e todos os estudantes o compram, sem que eu possa dizer-lhes para não fazer isso. (...) Canções italianas porque os estudantes amam a música italiana e, portanto, as atividades sucessivas são bem aceitas e agradáveis. Artigos de jornais italianos atuais para dar uma ideia do que é a Itália hoje, para tratar de cultura, atualidades (...). Trava-línguas para favorecer a fluência, o jogo, a distensão, a reflexão sobre a pronúncia (...)” (seis anos).

\footnotetext{
${ }^{66}$ Para preservar a identidade dos professores do IC que responderam nossas questões, não mencionamos o gênero, nem a idade deles. Nas transcrições de suas respostas, indicamos, entre parênteses, apenas o tempo de experiência que cada monitor tem no âmbito do ensino do italiano língua estrangeira.

${ }^{67} \mathrm{O}$ professor utilizou o pretérito imperfeito em sua resposta, porque quando respondeu nossas questões, não trabalhava mais no IC.
} 
- "Utilizo esses materiais para aprofundar determinados pontos gramaticais e principalmente para motivar a conversação e a reflexão dos estudantes sobre a língua italiana, uma vez que são abordados diferentes temas, como por exemplo a cultura" (oito anos).

Pelas respostas, pode-se notar que, para os oito professores, é importante complementar as aulas com outros materiais, ou seja, é relevante não se limitar à utilização do manual didático. Essa complementação faz-se necessária, segundo os docentes, para que sejam atendidos as necessidades e os interesses dos estudantes, para que sejam ampliados os conteúdos tratados no $\mathrm{LD}$, para que os alunos sintam-se mais motivados e para que estes possam adquirir a língua italiana e ter um contato maior com a língua utilizada em situações reais de comunicação, bem como com a cultura-alvo e com as atualidades referentes à Itália.

Quanto à interpretação de que, possivelmente, os discentes gostam mais dos materiais que o professor mais utiliza nas aulas de italiano, ou à de que o docente usa com maior frequência certos materiais porque os aprendizes gostam destes, parece-nos que a primeira prevaleça sobre a segunda. Essa parece ser a interpretação mais plausível, tendose em vista o fato de apenas um professor ter afirmado que emprega determinado material, porque os alunos gostam deste ("Canções italianas porque os estudantes amam a música italiana..." - docente de italiano há seis anos). 


\section{OS MATERIAIS AUTÊNTICOS NA SALA DE AULA DE ITALIANO LE: DESCRIÇÃO E APLICAÇÃO DE ALGUMAS ATIVIDADES}

Neste capítulo, com o objetivo de tentar mostrar, na prática, aspectos teóricos de que tratamos em capítulos anteriores, descreveremos o processo de didatização de alguns materiais autênticos e a aplicação desses materiais em nossas próprias aulas ministradas no Italiano no Campus para uma turma de nível I.

\subsection{A utilização de materiais autênticos em uma de nossas turmas iniciantes no estudo do italiano língua estrangeira}

Como dissemos no capítulo 4, lecionamos no Italiano no Campus de março de 2009 a abril de 2011. Nesses dois anos, demos aulas para turmas dos níveis I a V desse curso, isto é, trabalhamos com alunos dos níveis A1, A2 e B1, segundo a nomenclatura proposta pelo Quadro Comum Europeu de Referência para as Línguas.

Durante esse período, selecionamos, didatizamos e usamos alguns materiais autênticos em todas as nossas turmas: utilizamos canções em todos os níveis com que trabalhamos (I a V), empregamos histórias em quadrinhos e folhetos de supermercado no nível I, usamos textos literários nos níveis II, III, IV e V, fizemos uso dos gêneros textuais publicidade e curriculum vitae no nível IV.

Entretanto, em nossa dissertação de mestrado, descreveremos apenas algumas atividades baseadas em textos autênticos as quais elaboramos para o nível I e que aplicamos no primeiro semestre de 2010. Optamos por descrever somente algumas atividades aplicadas nesse nível, em detrimento dos outros, porque nos interessa tentar mostrar que o trabalho com esses valiosos instrumentos de ensino-aprendizagem da LE pode ser realizado em qualquer estágio de estudo da língua-alvo, inclusive no primeiro nível.

A classe em que aplicamos as atividades que serão descritas adiante era formada por doze alunos, com idades entre 21 e 60 anos; nesse grupo, havia nove mulheres e três homens. Seis desses estudantes eram graduados, quatro eram pós-graduados e dois eram graduandos. Suas áreas de formação eram: Biologia, Finanças, Psicologia, Economia, Geografia, Engenharia, Serviço Social, Informática e Arquitetura. Quanto às profissões, 
nossos alunos eram professores, secretários, psicólogos, engenheiros, assistentes sociais, técnicos em informática e arquitetos.

Como se vê, era uma turma bastante heterogênea; por isso, com o intuito de conhecê-la melhor, tivemos muitas conversas informais com cada aluno: eram sempre conversas breves, de poucos minutos, que aconteciam pouco antes do início das aulas, ou assim que as aulas terminavam. Nossas aulas eram às segundas e quartas-feiras, das $17 \mathrm{~h} 30$ às $19 \mathrm{~h}$.

No Italiano no Campus, temos de usar, obrigatoriamente, o livro didático Linea diretta, que se torna o principal material usado nas aulas. No nível I, são previstas as quatro primeiras unidades do Linea diretta $1 a$, cujos conteúdos são trabalhados, segundo os autores desse LD, de modo a atingir os seguintes objetivos comunicativos: cumprimentar, apresentar alguém, apresentar-se, oferecer alguma coisa, expor um problema, falar de alguém (unidade 1); pedir alguma coisa em um bar ou em um restaurante, solicitar algo de maneira gentil, oferecer algo, agradecer, contar (unidade 2); pedir confirmação, tranquilizar, solicitar e fornecer informações, confirmar uma reserva (unidade 3); pedir explicações para se chegar a um lugar, lamentar-se, explicar a alguém como chegar a um lugar (unidade 4).

Em cada nível do IC, temos quarenta e cinco horas para trabalhar quatro unidades do livro, e, no nível I, visando tornar mais dinâmicas e interessantes as aulas de nosso grupo iniciante, não nos limitamos a esse material, usamos materiais complementares.

A análise da pesquisa que fizemos com todas as turmas dos cursos extensivos do IC mostrou que as canções são, depois do livro didático, os materiais preferidos pelos alunos. Portanto, não poderíamos deixar de usá-las na sala de aula.

Especificamente, com o grupo do nível I já mencionado, usamos duas canções: "Ci vuole un fiore", de Sergio Endrigo, e "Laura non c'è", de Nek. As atividades que utilizamos com base na primeira canção foram retiradas de Canta che ti passa-imparare l'italiano con le canzoni, um livro que propõe atividades a partir de músicas italianas de diversos cantores. Por sua vez, as atividades realizadas com base na segunda canção foram elaboradas por nós e encontram-se ao final desta dissertação ${ }^{68}$.

Ao realizarmos tais atividades, nossos objetivos consistiam em possibilitar aos alunos o contato com canções que fazem parte do universo cultural italiano, desenvolver a compreensão oral dos estudantes, atender um interesse específico deles (o interesse pela

\footnotetext{
${ }^{68} \mathrm{Cf}$. apêndice D.
} 
música italiana) e, ao mesmo tempo, trabalhar com eles dois conteúdos gramaticais que se estudam no nível I: os artigos definidos e o verbo esserci.

A seguir, abordaremos a canção como importante instrumento no processo de ensino-aprendizagem de uma língua estrangeira e, depois, faremos brevíssimos comentários sobre as atividades aplicadas com base nas duas canções supracitadas.

\subsection{A canção nas aulas de italiano $L E^{69}$}

A análise das respostas dos alunos do Italiano no Campus ao nosso questionário evidenciou que a música italiana é muito apreciada por eles. Por isso, parece-nos que esse interesse dos alunos pelas canções italianas seja um bom motivo para usar tais materiais autênticos em nossas aulas.

Entretanto, obviamente, esse não é o único motivo para utilizarmos as canções na sala de aula. Como vimos no capítulo 2, esse material já era explorado em alguns métodos e abordagens de ensino: particularmente, na sugestopédia, a música tem um papel central, sendo, possivelmente, o principal material autêntico empregado nesse método.

Sob uma perspectiva neurolinguística, podemos dizer que, como a música ativa os dois hemisférios cerebrais, ela favorece estados de relaxamento e concentração ao mesmo tempo, os quais facilitam alguns processos cognitivos, como a memorização do léxico e de estruturas linguísticas (cf. DANESI, 1998).

Ademais, por ser um gênero textual universal, a canção pode trazer à tona sentimentos e emoções, favorecendo o desenvolvimento da criatividade e da sensibilidade. Desse modo, esse gênero, que é constituído pelas linguagens verbal (poética) e musical, consiste em um valioso material autêntico que pode ser utilizado nas aulas de italiano LE (e de outras línguas estrangeiras). No âmbito da pedagogia de línguas, segundo Caon (s.d.), é possível afirmar que a canção:

- ativa uma motivação baseada no prazer - essa motivação é profunda e estável, pois está ligada, geralmente, aos interesses dos aprendizes e à sua motivação intrínseca ${ }^{70}$;

\footnotetext{
${ }^{69}$ Parte das reflexões apresentadas em 5.2 e em 5.4 foi desenvolvida na monografia que apresentamos ao curso de Pós-Graduação lato sensu em Língua Portuguesa da Pontifícia Universidade Católica de São Paulo como requisito para obtenção do título de especialista em Língua Portuguesa. Esse trabalho, intitulado A didatização de textos autênticos para o ensino de português para falantes de outras línguas, foi concluído em dezembro de 2009 e está disponível na biblioteca dessa instituição de ensino.

${ }^{70}$ De acordo com Gardner (1985), a motivação intrínseca refere-se ao interesse geral que alguns indivíduos têm pela aprendizagem de línguas.
} 
- pode ser didatizada sob muitos aspectos - a partir desse texto autêntico, podem ser trabalhados aspectos lexicais, gramaticais, socioculturais, entre outros. Além disso, em muitas canções, há modos de dizer, frases feitas, gírias e regionalismos, que podem ser explorados junto aos alunos. Em geral, a canção constitui um material muito rico, pois apresenta diferentes níveis estilísticos, que podem servir como base para diversos percursos didáticos, de acordo com o perfil dos discentes e com o nível de estudo da LE em que eles se encontram;

- pode favorecer o trabalho com conteúdos culturais - a canção é muito mais do que uma criação de um artista, ela é o produto de uma cultura e de um determinado momento histórico. Isso pode representar, para os aprendizes, um incentivo para que eles se aproximem da cultura do povo falante nativo da língua-alvo e para que eles estabeleçam relações entre os conteúdos apresentados pela canção e os conhecimentos prévios referentes à sua própria cultura e à cultura-alvo;

- possibilita a memorização de fonemas, unidades lexicais e estruturas linguísticas não apenas na sala de aula, mas também fora dela. Como vimos no capítulo 4, a escuta de canções italianas é a principal forma de contato que os alunos estabelecem com a LE fora desse espaço. Assim, quando, por exemplo, fora da sala de aula, os alunos ouvem várias vezes uma canção italiana da qual gostam muito, eles lembram-se de algumas palavras e trechos da música, mesmo que não saibam seus significados. O professor poderia, desse modo, explorar esse fator, retomando léxico e estruturas "apreendidas" inconsciente e superficialmente pelos discentes, para permitir que eles os retomassem conscientemente nas aulas, através de atividades de sistematização. Essa seria uma forma de aproveitar os conhecimentos prévios dos alunos para favorecer a aprendizagem significativa da língua-alvo;

- propicia um trabalho eficaz no que se refere à pronúncia - a aprendizagem da pronúncia é facilitada por aspectos rítmicos próprios desse gênero textual;

- apresenta evidentes aspectos de ludicidade muito úteis à aprendizagem significativa da LE. De acordo com Caon, a ludicidade consiste em uma carga vital em que se integram aspectos motivacionais, afetivos, cognitivos e sociais do aprendiz. Esta é, segundo esse teórico, o princípio fundamental para a promoção do desenvolvimento global do aluno. O apelo à dimensão lúdica é importante para que o uso das canções nas aulas de LE seja considerado uma estratégia privilegiada de abordagem dos 
conteúdos linguísticos e culturais, para desenvolver um trabalho com a língua-alvo em um contexto de comunicação autêntica.

\subsubsection{As duas canções trabalhadas com nossa turma de nível I}

A primeira canção ("Ci vuole un fiore", de Sergio Endrigo) foi apresentada aos alunos na segunda semana de aula, em março de 2010. Todavia, as atividades que lhes propusemos a partir dessa canção não foram elaboradas por nós; nosso trabalho foi apenas o de selecionar algumas das atividades contidas no livro Canta che ti passa ${ }^{71}$.

As técnicas que selecionamos foram estas: associação palavra/imagem, questões de múltipla escolha, questões abertas, tabelas e preenchimento de espaços em branco durante a escuta da canção.

A segunda canção que usamos com essa turma (no início de maio de 2010) foi Laura non c'è, de Nek. A aula em que utilizamos essa canção, bem como algumas das demais aulas em que usamos materiais autênticos, foram, com a permissão ${ }^{72}$ dos alunos, registradas em áudio, para que, posteriormente, pudessem servir como material de análise para nossa pesquisa.

Para iniciar o trabalho com essa canção, com o intuito de explorar os conhecimentos prévios dos nossos discentes, propusemos-lhes uma atividade de préescuta: escrevemos, na lousa, o título da canção e solicitamos aos alunos que, a partir dele, fizessem inferências quanto ao conteúdo do texto em questão.

Para favorecer a elaboração de inferências, fizemos-lhes, oralmente, esta pergunta: “Chi è Laura ${ }^{73}$ ?". As respostas dos alunos foram: "una ragazza, una bambina, una signora $^{74}$ ". Como já tínhamos estudado o verbo esserci na aula anterior, os alunos

\footnotetext{
${ }^{71}$ Todas essas atividades encontram-se ao final deste trabalho: $\mathrm{cf}$. anexo A.

72 Solicitamos a permissão dos alunos por meio de um termo de autorização, que foi assinado por todos eles. Após a assinatura desse termo, entregamos a cada aluno um documento no qual nos comprometíamos a utilizar a gravação das aulas apenas para as finalidades de nossa pesquisa de Mestrado. Esses documentos foram usados em três de nossas turmas: uma de nível I, uma de nível II, e outra, de nível III. Registramos em áudio algumas aulas ministradas nesses três grupos e, somente depois, decidimos analisar apenas as do nível I, pelos motivos já explicitados anteriormente. Os termos de autorização e de compromisso encontram-se ao final desta dissertação: respectivamente, apêndices $\mathrm{E}$ e $\mathrm{F}$.

${ }^{73}$ Traduziremos do italiano (e de uma interlíngua que visa aproximar-se dessa língua-alvo) para o português, em nota de rodapé, os trechos da dissertação em que mostramos quase todas as nossas próprias falas e as dos alunos. Tradução da frase acima: “Quem é Laura?”. Resposta dos estudantes: “uma moça, uma menina, uma senhora”.

${ }^{74}$ Nos trechos desta dissertação em que transcrevemos as nossas falas e as dos discentes, não seguimos normas de transcrição de textos orais, como as da Análise da Conversação; utilizamos a transcrição ortográfica, mantendo, contudo, os "erros" cometidos pelos alunos e por nós. Optamos por não fazer uso de normas de
} 
disseram ter entendido o título da canção, e eles mesmos começaram a nos perguntar: "dove Laura non è ?75". Devolvi-lhes a pergunta, e eles disseram: "qui". Então, uma aluna questionou: “qui dove 76 ?”; e, em seguida, essa mesma aluna disse: "será que ela viajou, ou será que foi embora daqui ${ }^{77}$ ?".

Depois dessas questões e respostas propostas pelos aprendizes, fizemos a atividade de escuta da canção, com o intuito de praticar a compreensão oral. Após essa primeira escuta, perguntamos-lhes se tinham entendido um pouco da canção, e eles disseram que sim. Mas, pediram-nos para deixá-los ouvi-la novamente, por isso, fizemos, juntos, uma segunda escuta. Ao fazer isso, ainda não tínhamos dado aos discentes a letra da música.

Antes de escutar a canção pela terceira vez, entregamos-lhes as atividades que elaboramos. Como se vê no apêndice $\mathrm{D}$, as técnicas que usamos para didatizar esse material autêntico foram muito similares às que os autores de Canta che ti passa utilizaram para didatizar " $\mathrm{Ci}$ vuole un fiore": preenchimento de espaços em branco durante a escuta da canção, questões de múltipla escolha referentes à compreensão do texto, tabelas e perguntas abertas.

Entre as atividades baseadas nas duas canções, não havia nenhuma que exigisse a compreensão de detalhes do texto, pois tendo em vista que nossos alunos eram principiantes, interessava-nos que eles desenvolvessem uma compreensão geral de ambas as canções.

Os alunos fizeram, em duplas, as atividades; e, depois, fizemos, todos juntos, a correção delas, para que todos os estudantes pudessem ler suas respostas, principalmente as que se referiam às suas experiências e opiniões pessoais.

transcrição de textos orais, pois o objetivo deste trabalho não está relacionado à análise desses textos. Assim, ao fazer as transcrições, eliminamos elementos típicos de interações orais, como as pausas, as repetições e as hesitações.

${ }^{75}$ Tradução: “Onde Laura não está?”. Resposta dos estudantes: “aqui”.

76 Tradução: "aqui onde?”.

${ }^{77}$ Naquele momento da aula, a estudante falou em português, talvez, pelo fato de ter dito uma frase muito complexa para um nível inicial de estudo do italiano. A frase em italiano seria: "Avrà viaggiato o sarà andata via da qui?". Combinamos, com os alunos, desde a primeira aula, que falaríamos praticamente sempre em italiano. Notamos que, ao falar conosco, geralmente, os estudantes esforçavam-se para falar na língua-alvo, mesmo nas primeiras aulas; mas, muitas vezes, quando conversavam entre si durante as atividades, eles falavam em português. Por se tratar de uma turma de nível I, não os repreendíamos nos momentos em que eles usavam a língua materna; inclusive porque, como vimos no capítulo 1, a LM serve como ponto de apoio para a aprendizagem significativa da LE. Além disso, quando os alunos solicitavam, lhes dávamos breves explicações em português. Entretanto, com as turmas de níveis mais avançados, procurávamos ser mais exigentes no que se refere ao uso da LE nas aulas, isto é, procurávamos incentivar os discentes a evitar a utilização do português na sala de aula. 
Ao final das atividades, todos os alunos disseram ter gostado muito da canção: alguns disseram que gostaram dela por seu ritmo; outros, pelo texto; e outros, tanto pelo ritmo quanto pela letra da canção.

Para encerrar aquela aula, escutamos "Laura non c'è” pela quarta vez. Ao fazer a quarta escuta, notamos que, dos nove alunos presentes na sala de aula, sete cantavam a canção enquanto a escutavam, embora isso não tivesse sido solicitado. Essa atitude parece demonstrar que eles realmente gostaram desse texto autêntico.

Assim, pudemos constatar que, ao usar materiais autênticos, mesmo com atividades muito simples, as aulas podem tornar-se mais interessantes tanto para os aprendizes quanto para nós, professores de italiano LE.

Todavia, como é muito curto o tempo de que dispomos para atividades que não se restrinjam às do livro didático, não pudemos propor, à nossa classe, atividades baseadas em outras canções. Teria sido muito bom, se tivéssemos tido, por exemplo, tempo suficiente para solicitar que cada aluno escolhesse sua canção italiana preferida, e criássemos, a partir de algumas delas, atividades que pudessem envolver os aspectos cognitivos e afetivos dos estudantes. Talvez, no entanto, isso seja possível apenas em um curso específico de italiano por meio de canções, ou em um curso cujo programa seja mais flexível quanto aos conteúdos.

\subsection{A escolha do gênero textual folheto de supermercado}

Além das duas canções, trabalhamos, também, o gênero folheto de supermercado. Optamos por trabalhar com esse gênero textual, por se tratar de um gênero do cotidiano, isto é, um gênero com o qual todos nos deparamos em nosso dia a dia. Obviamente, há outros gêneros textuais que fazem parte de nossa vida cotidiana, mas, não foi por acaso que escolhemos o folheto de supermercado como material autêntico a ser explorado com nossa turma do primeiro nível. A seguir, procuraremos explicar o motivo de tal escolha.

A ideia de trabalharmos com o material em questão surgiu quando começamos a estudar a unidade 2 do livro Linea diretta. Ao lermos com os alunos a lista de preços contida na página $20^{78}$ desse manual, os aprendizes fizeram-nos muitas perguntas referentes ao significado das palavras dessa lista: todas elas diziam respeito a comidas e bebidas.

\footnotetext{
${ }^{78} \mathrm{Cf}$. anexo B.
} 
Uma aluna perguntou-nos, ao ver, em tal lista, "succo di frutta": "succo di quale frutta?". Respondemos a ela: "In Italia di solito non ci sono molti tipi di succhi di frutta come qui, quindi credo siano succhi di arancia, pesca e pera, che mi sembrano quelli più comuni là”. Então, essa aluna disse-nos: "non apprenderemo i nomi delle altri frutte ${ }^{79}$ ?". A essa questão, respondemos: "Sì, certo! Ma non li studieremo adesso ${ }^{80}$ ".

Após essa aula, refletimos sobre essa e outras curiosidades dos alunos e tentamos pensar em alguma forma de apresentar-lhes um pouco do léxico referente aos alimentos de forma contextualizada. Foi assim que tivemos a ideia de empregar, em nossas aulas, o folheto de supermercado, gênero que contém várias palavras do campo lexical dos alimentos e que, além disso, contém imagens, o que pode facilitar a compreensão dos discentes e fazer com que eles não recorram tanto ao dicionário ou ao professor, para saber o significado das palavras.

Nas vezes em que estivemos na Itália, fizemos uma coleção de materiais autênticos: guardamos bilhetes de trem e de ônibus; rótulos de garrafas, de xampu, de condicionador; embalagens de sabonete; cartões postais; publicidades; revistas; DVDs de filmes; CDs de cantores italianos; bulas de medicamentos; entre outros. Dentre esses materiais, havia folhetos de supermercado; porém eram de julho de 2007 e, portanto, talvez, não fossem tão interessantes para os alunos, uma vez que não eram folhetos atuais.

Por isso, acessamos o site do Carrefour italiano ${ }^{81}$ e fizemos nosso cadastro na página desse hipermercado, para ter acesso aos folhetos com as ofertas do mês de abril de 2010, mês em que faríamos com os discentes as atividades baseadas nesse material autêntico. O folheto de supermercado que usamos para preparar as atividades que aplicamos nessa turma do nível I encontra-se anexado ao final desta dissertação ${ }^{82}$.

\subsubsection{A didatização de um folheto de supermercado}

Selecionado o gênero textual a ser trabalhado, fizemos um levantamento das características gerais desse gênero quanto:

\footnotetext{
${ }^{79}$ Nas transcrições das falas dos alunos (bem como das nossas), tanto em italiano quanto em português, não fizemos qualquer tipo de correção.

${ }^{80}$ Tradução da pergunta da aluna: "Suco de qual fruta?". Nossa resposta: "Na Itália, geralmente, não há muitos tipos de sucos de frutas como aqui, então acredito que sejam sucos de laranja, pêssego e pera, que me parecem ser os mais comuns lá". Questão feita pela estudante: "Não aprenderemos os nomes das outras frutas?". Nossa resposta: "Sim, claro! Mas, não os estudaremos agora".

${ }^{81}$ Site: http://www.carrefour.it/. Acesso em 05 de abril de 2010.

${ }^{82} \mathrm{Cf}$. anexo C.
} 
- ao suporte - o folheto de supermercado que selecionamos foi retirado do site do supermercado Carrefour italiano, portanto o site seria o suporte original desse gênero. No entanto, como no IC não dispomos de uma sala em que os alunos possam usar computadores e ter acesso à internet, tivemos de imprimir o folheto e tirar cópias dele, para que todos os estudantes o tivessem. Assim, o suporte do material que utilizamos com eles deixou de ser o site e passou a ser o papel (folhas de sulfite);

- à função social - esse gênero tem uma função utilitária, que consiste em divulgar produtos a serem vendidos;

- ao nível de linguagem predominante - o folheto de supermercado é um gênero em que predomina a linguagem informal, como se pode notar, por exemplo, pelo uso de verbos no imperativo informal no folheto que escolhemos: “Adquira 3 produtos e receba um voucher ${ }^{83}$ ";

- ao tipo textual predominante - como é sabido, não há tipos textuais puros, embora um sempre predomine. Nesse exemplar do gênero folheto de supermercado que escolhemos, há descrições dos produtos e imagens de cada um deles; essas descrições, aliadas às imagens, podem funcionar como argumentos. Entretanto, no folheto, há,

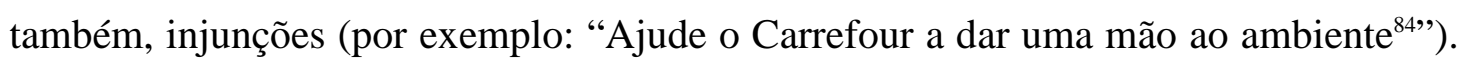
Assim, se levarmos em conta que o principal propósito comunicativo do gênero em questão consiste em divulgar os produtos com o intuito de vendê-los, é possível dizer que o tipo textual predominante nele é o argumentativo: as descrições dos produtos, juntamente com as imagens (textos não verbais, ou visuais), podem ser consideradas argumentos para convencer o consumidor a comprar tais produtos;

- ao domínio discursivo a que pertence - o folheto de supermercado é um gênero textual do domínio publicitário.

Realizado esse levantamento, que nos auxilia a ter familiaridade com o gênero textual escolhido para melhor explorá-lo do ponto de vista didático, começamos a elaborar as atividades a serem utilizadas com nossos alunos. Para elaborá-las, tínhamos em mente os seguintes objetivos a serem atingidos pelos aprendizes durante a realização delas:

- ampliar o repertório lexical referente às comidas e bebidas;

- conhecer algumas palavras do campo lexical do dinheiro;

\footnotetext{
${ }^{83}$ No original: "Acquista 3 prodotti e ricevi un voucher" (página 10 do folheto de supermercado que usamos com os alunos).

${ }^{84}$ No original: "Aiuta Carrefour a dare una mano all'ambiente" (página 16 do mesmo folheto de supermercado).
} 
- conhecer algumas expressões referentes às compras, como "a buon mercato" (colocação nominal), "fare spese" e "fare la spesa" (colocações verbais);

- perceber algumas diferenças quanto às modalidades oral e escrita da língua italiana.

Esses eram nossos objetivos principais ao propor tais atividades a nossos discentes. Agrupamos, em uma pequena apostila, os exercícios que elaboramos e, a seguir, comentamos cada atividade.

Esercizio 1. Da' un'occhiata al volantino dell'ipermercato Carrefour. Adesso metti i nomi dei prodotti nelle colonne giuste:

\begin{tabular}{|lccccc|}
\hline certosa & birra & torta & parmigiano & tacchino & quartirolo \\
arancia & branzino & & cozze & mascarpone & scamorza \\
gelato & würstel & salame & tè & succo & banane \\
\hline
\end{tabular}

\begin{tabular}{|c|c|c|c|c|c|c|}
\hline Dolce & Formaggio & Frutta & Bibita & Mollusco & Pesce & Carne \\
\hline & & & & & & \\
\hline & & & & & & \\
\hline & & & & & & \\
\hline & & & & & & \\
\hline
\end{tabular}

No primeiro exercício, como se vê, preparamos uma tabela na qual os alunos deveriam inserir os nomes dos produtos nas colunas certas. Esses nomes foram retirados de diferentes páginas do folheto de supermercado com base no qual elaboramos as atividades e eram todos hipônimos das palavras que já tínhamos inserido na tabela. Assim, a tarefa dos alunos consistia em relacionar cada hipônimo ao seu respectivo hiperônimo, para completar a tabela. Essa técnica didática facilita a memorização do léxico, segundo Mezzadri (2003).

Além disso, ao propor uma tabela com hiperônimos a ser completada com seus hipônimos, tínhamos como objetivo facilitar, também, o processo de aprendizagem significativa da língua-alvo por nossos estudantes: como vimos, para Ausubel (1968), a rede de conhecimentos, na mente humana, está organizada de forma hierárquica; no topo dessa estrutura, estão os elementos mais abrangentes e, subordinados a eles, estão os elementos mais específicos.

Assim, um exercício em que os discentes partem dos hiperônimos para chegarem aos hipônimos assemelha-se, numa perspectiva cognitivista, à organização dos 
conhecimentos na mente do aluno, e isso pode facilitar a aprendizagem significativa da LE pelos estudantes, no sentido de que eles irão, provavelmente, relacionar os hiperônimos que eles já conhecem (até porque as palavras que selecionamos são, quase todas, similares às mesmas palavras em português) aos hipônimos que eles estão por aprender.

Esercizio 2. Cerca sul volantino almeno cinque parole al singolare e cinque al plurale. Inseriscile nella tabella e scrivi davanti ad ogni parola l'articolo determinativo giusto:

\begin{tabular}{|l|l|}
\hline Maschile/Femminile Singolare & Maschile/Femminile Plurale \\
\hline & \\
\hline & \\
\hline & \\
\hline & \\
\hline
\end{tabular}

No segundo exercício, de tipo gramatical, solicitamos que os alunos procurassem, no folheto de supermercado, cinco palavras no singular e cinco no plural e escrevessem, antes de cada palavra, o artigo definido correto. Com essa atividade, pretendíamos que os estudantes retomassem um conteúdo gramatical que estudamos nas primeiras aulas: os artigos definidos.

Esercizio 3. Osserva il volantino e fa' la tua lista della spesa settimanale. Accanto ad ogni prodotto che vuoi comprare metti il suo prezzo. Poi fa' i conti e scrivi sotto quanti soldi spenderai:

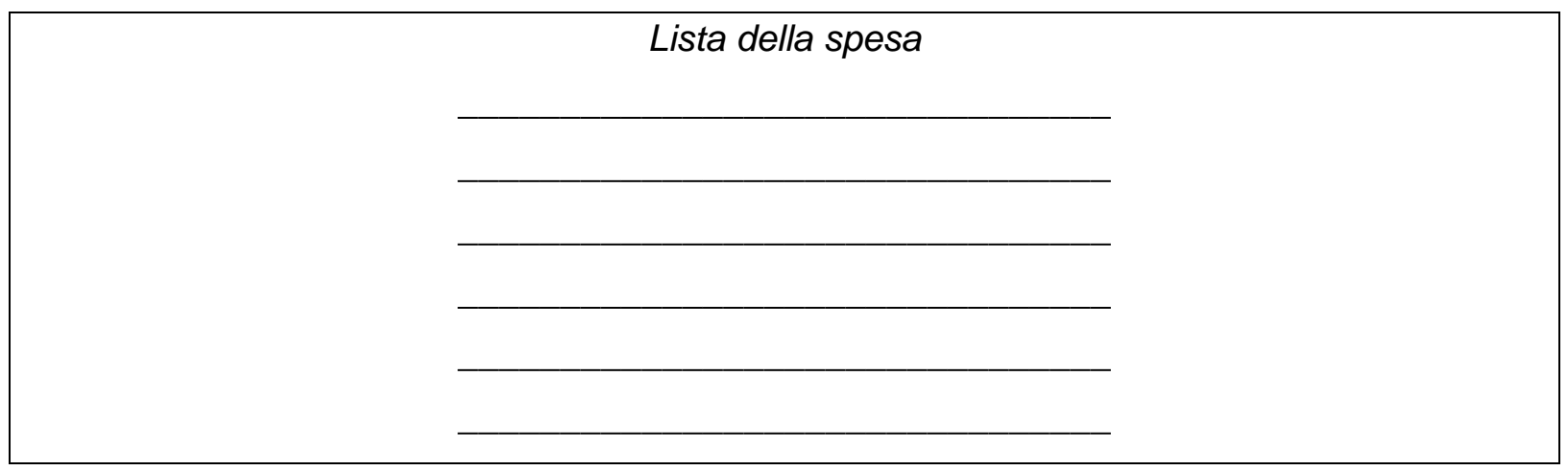

O exercício 3 consistia em uma atividade de produção escrita em que os alunos deveriam, a partir da leitura do folheto de supermercado, produzir um gênero textual 
específico: a lista de compras. Após escrevê-la, para saber quanto eles gastariam, deveriam somar os valores dos produtos que eles gostariam de comprar.

Tendo em vista que, no nível I, os discentes ainda não têm um vasto repertório linguístico para produzir, sem o auxílio de modelos, gêneros textuais mais complexos, solicitamos-lhes que escrevessem uma lista de compras. Fizemos essa solicitação justamente porque a lista de compras é um gênero textual muito simples e, portanto, a nosso ver, bastante adequado ao trabalho com estudantes do nível iniciante.

Esercizio 4. Quanto costa? / Quanto costano?

Osserva le frasi seguenti:

Un chilo di branzino costa 6,98 euro.

Le fette di pesce spada costano 16,98 euro.

Le cozze costano 1,38 euro.

La panna costa 0,75 euro.

Qual è il plurale di euro?

Adesso completa le frasi con il verbo costare e con i prezzi dei seguenti prodotti:

Esempio: II mascarpone Carrefour costa 1,79 euro.

a) Gli yogurt Parmalat

b) Le uova fresche grandi Ovito

c) II gelato Carte d'Or Algida

d) II minestrone Tradizione Findus

e) II lambrusco Pignoletto

No quarto exercício, nossos escopos eram puramente gramaticais: fazer com que os alunos percebessem que o substantivo "euro" não tem plural em italiano, ou melhor, que esse substantivo apresenta uma única forma para o singular e para o plural; fazê-los utilizar o verbo "custar" de forma correta, no singular e no plural.

Esercizio 5. Quando un prodotto costa poco si dice che è un prodotto economico o a buon mercato. Invece quando costa molto si dice che è caro o costoso. In questo volantino che cosa costa poco e che cosa costa molto secondo te? Sfoglialo, scegli alcuni prodotti e scrivi nella tabella i loro nomi e i loro prezzi: 


\begin{tabular}{|l|l|}
\hline Prodotti a buon mercato & Prodotti cari \\
\hline & \\
\hline & \\
\hline & \\
\hline & \\
\hline
\end{tabular}

O quinto exercício tinha o objetivo de apresentar aos discentes a colocação nominal "a buon mercato", muito usada em situações informais para referir-se a algo que tenha um bom preço, um preço baixo, vantajoso. Além disso, tínhamos outro objetivo de tipo lexical com essa atividade: apresentar aos alunos dois antônimos dessa expressão, isto é, "caro", "costoso".

Esercizio 6. Insieme ad un compagno, leggi i dialoghi.

Siete al Carrefour. uno di voi lavora all'ipermercato e l'altro è il cliente. Hai già fatto la spesa e vai alla cassa per pagare quello che hai messo nel carrello:

I.

Cliente (C): Buongiorno!

Cassiere (Ca): Buongiorno signore(a)! Allora, un etto di parmigiano reggiano, una torta chantilly, una pizza margherita e due bottiglie di acqua Vera. Sono 14,28 euro, signore(a).

C (Il cliente paga la spesa con una banconota da 50 euro): Ecco a Lei!

Ca: (il cassiere dà il resto al cliente): II resto è di 35,72 euro, giusto?

C: Sì. Allora, grazie!

Ca: Grazie a Lei!

C: Prego! Arrivederci!

Ca: Arrivederci!

II.

Cliente (C): Buonasera!

Cassiere (Ca): Buonasera signore(a)! Allora, 175 euro. (II cassiere calcola il prezzo della spesa).

C: Posso pagare con un assegno?

Ca: No, signore(a), mi dispiace.

C: E con la carta di credito?

Ca: Sì, con la carta di credito sì.

C: Benissimo. (Il cliente paga la spesa) 
Ca: Grazie!

C: Prego! Grazie a Lei! Arrivederci!

Ca: Arrivederci!

Dopo aver letto i dialoghi con il tuo compagno, rileggili con un altro compagno.

Com o exercício 6, pretendíamos que os estudantes realizassem, primeiramente, a leitura em duplas, para exercitarem a pronúncia e familiarizarem-se com algumas unidades lexicais, como: "banconota", "cassiere", "etto" etc.

Depois, sugeriríamos que eles fizessem a dramatização dos diálogos. A ideia era a de simular, na sala de aula, o momento de pagar as compras no hipermercado, em que um aluno seria o funcionário (caixa), e o outro, o cliente. Propusemos-lhes um diálogo já pronto, em vez de solicitar-lhes que elaborassem um, tendo em vista que essas atividades seriam realizadas apenas um mês e meio após o início das aulas, isto é, quando os alunos teriam tido apenas cerca de quinze horas de aulas de italiano LE. A nosso ver, como nossos aprendizes eram do nível I e estudavam a língua-alvo há apenas algumas semanas, seria mais fácil, para eles, dramatizar um diálogo já pronto do que criar um.

Esses dois diálogos que elaboramos e propusemos como exercício (bem como o diálogo do exercício 10, que mostraremos mais adiante) são muito semelhantes aos que se encontram em livros didáticos de italiano. Portanto, tais textos são didáticos; somente poderiam ser considerados autênticos com base nos postulados de Pallotti (1998). Para esse autor, se um texto é autêntico quando é criado para uma determinada comunidade, e, se os aprendizes estrangeiros são considerados uma comunidade, então até mesmo o texto elaborado com fins didáticos pode ser considerado autêntico.

Ademais, na concepção de Franzoni (1992), os diálogos que elaboramos para os exercícios 6 e 10 também poderiam ser considerados textos autentificados.

Esercizio 7. Quando compriamo qualcosa, possiamo pagare:

- con un assegno ${ }^{85}$

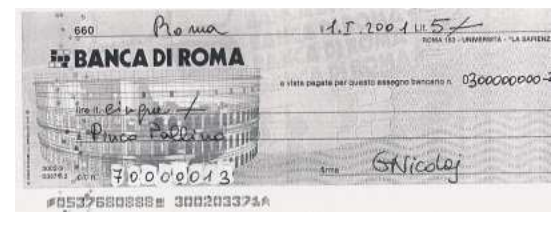

\footnotetext{
${ }^{85}$ As imagens que usamos para elaborar nossa apostila foram retiradas, no dia 10 de abril de 2010, destes sites: http://www.google.com.br/images?um=1\&hl=ptbr\&tbm=isch\&sa=1\&q=cozinheiro+desenho\&aq=f\&aqi=g10\&a $\mathrm{ql}=\& o \mathrm{q}=$
} 
- con la carta di credito
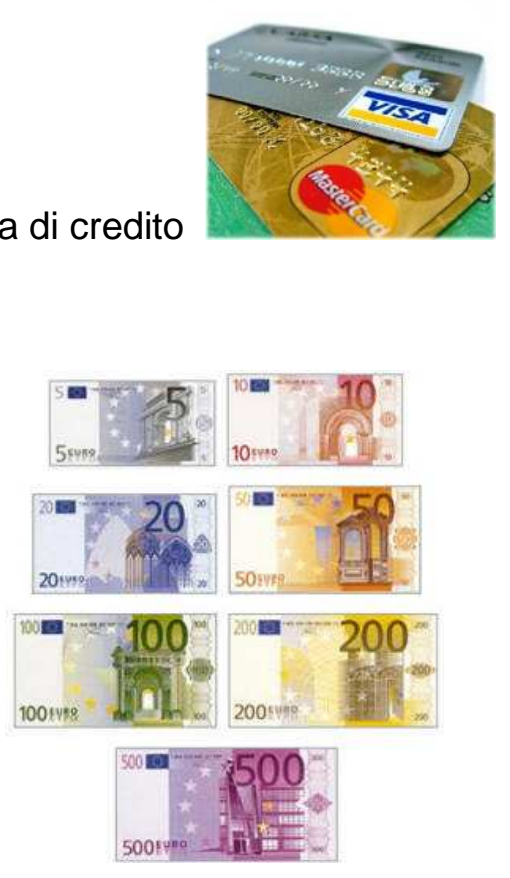

- in contanti

I contanti possono essere:

- le banconote (come queste sopra);

○ gli spiccioli

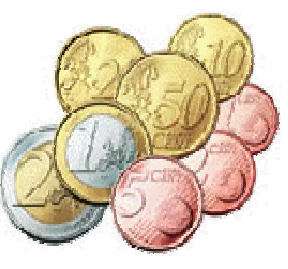

Tu di solito come paghi la spesa?

Fa' questa domanda ad almeno tre compagni e scrivi sotto le loro risposte:

\begin{tabular}{|l|l|}
\hline Nome del (della) compagno(a) & Lui/lei paga la spesa... \\
\hline & \\
\hline & \\
\hline & \\
\hline
\end{tabular}

Com a atividade $\mathrm{n}^{\mathrm{o}} 7$, nossos objetivos consistiam em apresentar aos discentes palavras do campo lexical do dinheiro e possibilitar a interação dos alunos entre si: eles 
deveriam caminhar pela sala de aula e perguntar aos colegas como eles, geralmente, pagam as compras: em dinheiro, com cheque ou com cartão de crédito.

Enquanto conversavam com os colegas, deveriam escrever suas respostas na tabela e, em seguida, cada aprendiz deveria apresentar à classe os resultados da conversa, dizendo, por exemplo: A (nome do estudante) paga as compras com cartão de crédito; B paga as compras em dinheiro etc.

Esercizio 8. Fare spese o fare la spesa?

Ecco alcuni significati della parola spesa:

1. I'acquisto per il quale si spende una determinata somma di denaro. Esempi: fare una buona, una cattiva spesa; andare al centro a fare spese;

2. I'acquisto di generi alimentari e di altri prodotti necessari al mantenimento della famiglia. Esempi: la mamma è uscita a fare la spesa; la borsa della spesa; tornare a casa con la spesa.

Definizioni tratte dal dizionario on line Garzanti:

http://garzantilinguistica.sapere.it/it/dizionario/it/lemma/56fe7602c2b696717ff6711852380499 7ead8abc, 10 aprile 2010

Leggi le definizioni sopra e le frasi in grassetto, poi rispondi alla domanda: quando andiamo a comprare le cose da mangiare e da bere, facciamo spese o facciamo la spesa? Confronta la tua risposta con quella di un compagno.

O objetivo principal do exercício 8 era lexical: apresentar aos alunos duas colocações verbais "fare spese" e "fare la spesa". Os aprendizes deveriam ler os dois significados da palavra "spesa", retirados do dicionário, e analisar as frases em negrito, para poder responder se, quando vamos ao supermercado, fazemos "spese" ou "la spesa". Após responderem a pergunta, cada discente deveria comparar sua resposta à de um colega e discuti-la com ele. Portanto, com essa atividade, também pretendíamos incentivar a produção oral dos estudantes. 
Esercizio 9. Attività in piccoli gruppi. Avete 70 euro da spendere e volete preparare una cena per alcuni vostri amici. Decidete cosa comprerete e quali piatti preparerete. Fate la vostra lista della spesa e scrivete un piccolo menù:
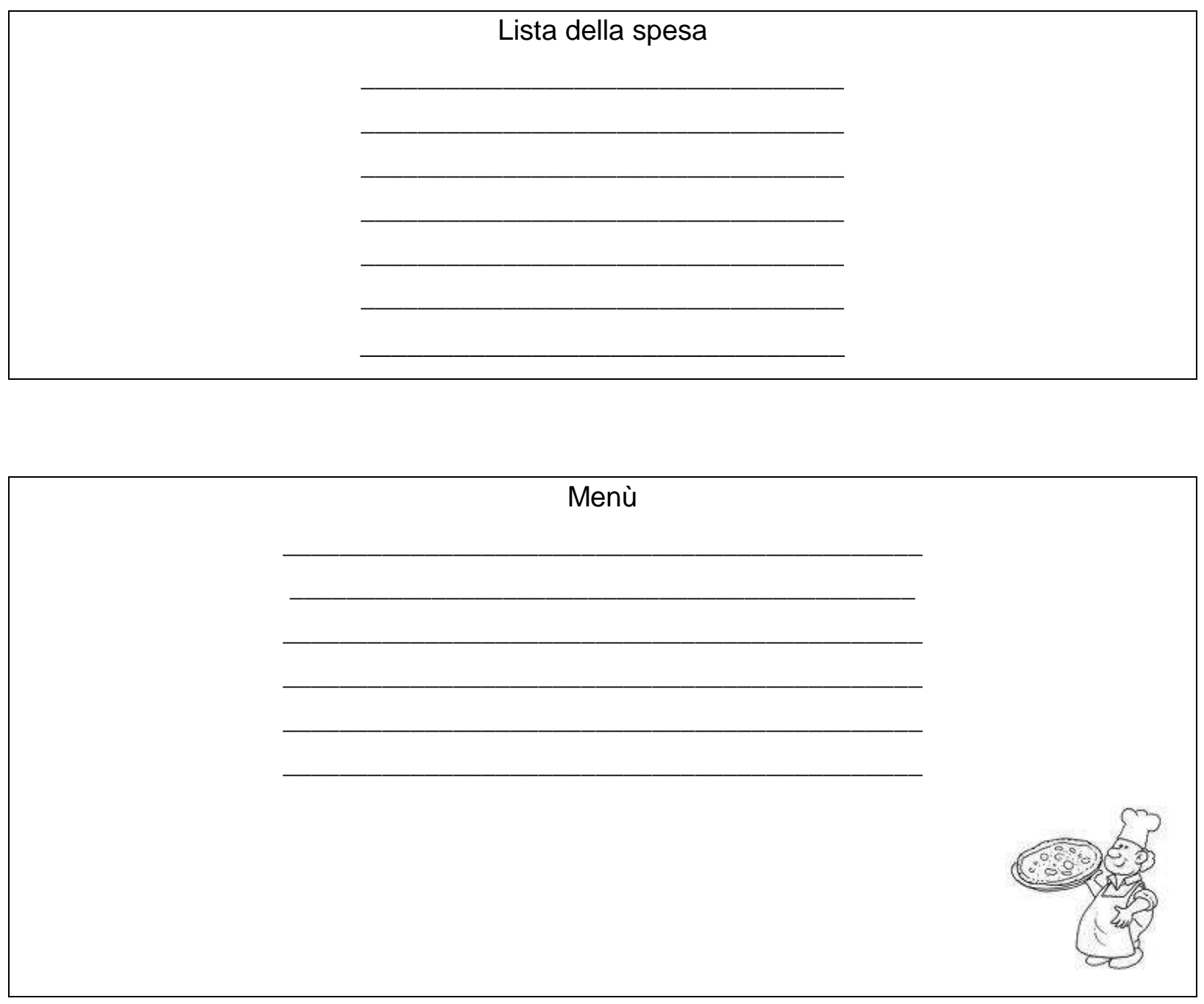

A atividade 9 era uma tarefa em grupo, que consistia na preparação de um jantar para os amigos. Cada grupo de três ou quatro alunos tinha setenta euros para gastar nessa preparação. Para tanto, eles deveriam produzir, juntos, dois gêneros textuais: a lista de compras e o cardápio.

Para escrever o primeiro, seria necessário que os discentes observassem, novamente, o folheto de supermercado e escolhessem, nele, os produtos a serem comprados para prepararem os pratos que eles serviriam em tal jantar. Por sua vez, a escrita do segundo exigiria dos alunos um consenso quanto aos pratos a serem preparados. 
Com essa tarefa, nossos objetivos consistiam em favorecer a interação dos aprendizes uns com os outros, possibilitar-lhes uma revisão do léxico referente às comidas e bebidas e incentivar a produção oral dos estudantes.

Esercizio 10. Paolo incontra il suo amico Luigi e gli fa un invito a cena. Leggi il dialogo con un compagno:

\section{Paolo (P): Ciao Luigi!}

Luigi (L): Ciao Paolo! Come stai?

P: Bene, grazie! E tu?

L: Anch'io sto bene, grazie!

P: Senti, vuoi venire a cena a casa mia domani?

L: Certo! Volentieri! Grazie per l'invito!

P: Prego! Ti aspetto domani alle 19.30 allora.

L: Ok. Grazie ancora!

P: Figurati!

Anche tu hai appena incontrato uno degli amici che vuoi invitare a cena. Fagli l'invito.

Che coincidenza! Un'ora dopo hai incontrato pure un altro tuo amico che non vedevi da settimane ma che pensavi di invitare a cena. Quindi fa' l'invito anche a lui.

No exercício 10, os aprendizes deveriam, primeiramente, ler, em duplas, o diálogo acima, que se trata de um convite (bastante informal) para um jantar. Em seguida, deveriam relê-lo, mas com outro colega, e os nomes dos personagens deveriam ser substituídos pelos dos próprios alunos.

Como mostramos no capítulo 4 de nossa dissertação, os estudantes do Italiano no Campus, em geral, não gostam muito da atividade de produção oral em que eles devem seguir modelos; eles preferem produções orais mais livres. No entanto, a nosso ver, como nosso grupo era de alunos iniciantes, cujas aulas tinham começado há pouco mais de um mês, era necessário que eles produzissem textos orais a partir de modelos, ou seja, que eles reproduzissem textos já prontos.

Esercizio 11. Hai già invitato i due amici che hai incontrato. Adesso telefona ai tuoi altri amici e invita anche loro a cena. 
No exercício 11, a proposta era a de fazer, novamente, um convite para um jantar, mas, dessa vez, por telefone, e não pessoalmente, como na atividade 10. Nossa ideia era a de que, comparando os convites feitos pessoalmente e por telefone, os alunos percebessem algumas especificidades de cada um desses convites.

Esercizio 12. Ora hai invitato quasi tutti gli amici che volevi, ne manca solo uno. Hai provato a telefonargli ma non sei riuscito a parlarci, dunque scrivigli una mail per invitarlo a cena.

O exercício 12, por sua vez, tinha como objetivo a escrita de um convite, isto é, após terem convidado, pessoalmente e por telefone, alguns amigos para jantar, os discentes deveriam fazer o mesmo convite a outro amigo, porém por e-mail. Nossa ideia, ao propor tal atividade, consistia em favorecer reflexões dos alunos quanto às diferenças entre a língua oral e a escrita, uma vez que eles deveriam transpor para a língua escrita um gênero textual já praticado por eles oralmente. Todas essas atividades constituem a sequência didática ${ }^{86}$ que elaboramos com base no gênero textual folheto de supermercado.

\subsubsection{A aplicação das atividades elaboradas com base no gênero textual folheto de supermercado: relatos de prática}

Após termos didatizado o folheto do hipermercado Carrefour italiano, aplicamos as atividades na sala de aula. No total, para que os aprendizes fizessem todas as atividades que lhes propusemos foram necessárias cinco horas e meia, ou seja, quase quatro aulas (uma vez que cada aula tem a duração de uma hora e meia). A seguir, descreveremos como foi a aplicação de tais atividades.

Para ter registros dessa aplicação, fizemos, durante (e, às vezes, após) cada aula, anotações concernentes à maneira como os alunos agiam em cada atividade: enquanto os

\footnotetext{
${ }^{86}$ Marcuschi (2008, p. 213), retomando Dolz e Schneuwly (1994), afirma que a sequência didática é "um conjunto de atividades escolares organizadas, de maneira sistemática, em torno de um gênero textual oral ou escrito".
} 
discentes faziam as atividades, andávamos pela sala de aula, para orientá-los em cada uma delas e esclarecer eventuais dúvidas; assim, tivemos tempo de fazer várias anotações durante as próprias aulas. Ademais, gravamos em áudio duas dessas quatro aulas.

Para iniciar as atividades, entregamos a cada estudante uma cópia do folheto de supermercado já mencionado e demos a eles dez minutos para observá-lo. Como as cópias eram em preto e branco, levamos, para a classe, também, uma cópia colorida, para que os discentes pudessem ver o folheto com suas cores originais.

Embora o folheto tivesse dezesseis páginas, explicamos aos aprendizes que, naquela aula e nas seguintes, usaríamos apenas as nove primeiras páginas desse material autêntico; ou seja, entregamos a cada aluno uma cópia do folheto inteiro, mas esclarecemos-lhes que nos seriam úteis, nas aulas em questão, apenas as páginas já citadas.

Para fazer as atividades 1 e 2, propusemos aos discentes que se organizassem em duplas, porque, assim, eles poderiam ajudar um ao outro. Enquanto faziam o primeiro exercício, notamos que eles falavam muito mais em português do que em italiano, o que é aceitável, visto que se tratava de uma turma de nível básico. No entanto, dizíamos-lhes em alguns momentos: "parlate in italiano ${ }^{87}$ !".

Numa das duplas, formada por um aluno de vinte e quatro e uma aluna de trinta e oito anos, a estudante disse a esse colega: “würstel? Cos'è ${ }^{88}$ Não achei ainda nel volantino $^{89}$ ". O discente, que também ainda não tinha encontrado a imagem que correspondia a essa palavra, disse à colega: "Em alemão, questa parola significa salsicha. Será que é isso in italiano anche?". Decorridos alguns minutos, eles encontraram a imagem, e o aluno exclamou: "É uguale in alemão!".

Esse breve diálogo entre esses dois aprendizes ilustra a importância dos conhecimentos prévios referentes não só à língua materna dos estudantes, mas também a outras línguas estrangeiras que os discentes já tenham estudado: o fato de o aluno conhecer aquela palavra em alemão, língua que ele estudou por dois anos e meio (conforme ele mesmo nos disse), ajudou-o a compreender o significado da palavra em italiano. Esse exemplo, a nosso ver, mostra a relevância, no processo de aprendizagem

\footnotetext{
${ }^{87}$ Tradução: "Falem em italiano!".

${ }^{88}$ Tradução da frase dita pela aluna: "Würstel? O que é? (...) no folheto”. Resposta do aluno: “(...) esta palavra (...) em italiano também?"”.

${ }^{89} \mathrm{Em}$ muitos momentos dessas aulas (e de quase todas as aulas do semestre), os discentes misturavam a línguaalvo com sua língua materna, o que também nos parece aceitável, tendo em vista os postulados de Ausubel (1968) expostos no primeiro capítulo deste trabalho. Segundo esse autor, é impossível que o aprendiz se esqueça de sua língua materna, ao estudar outras línguas e, portanto, os conhecimentos que o aluno tem da e na sua LM servirão sempre como ponto de apoio para a construção dos conhecimentos da e na língua-alvo.
} 
significativa da língua-alvo, dos conhecimentos prévios que os alunos têm de outros idiomas (e, obviamente, de sua própria língua materna).

Para fazer a correção dos dois primeiros exercícios, solicitamos a duas duplas que lessem suas respostas à classe, e, à medida que surgiam dúvidas dos discentes, procurávamos esclarecê-las a todo o grupo.

Ao fazer as atividades 3, 4, 5 e 6, os alunos pareciam estar bastante concentrados e, quando fizemos, juntos, a correção de tais exercícios, não demonstraram ter dúvidas, o que pode significar que eles os compreenderam bem, ou que os acharam muito fáceis. Aliás, na verdade, durante a realização dessas atividades, surgiu uma única dúvida de uma discente, que nos perguntou: "Cosa significa etto?" Respondemos-lhe: "cento grammi ${ }^{90 "}$. Após essa brevíssima resposta, a aluna pareceu entender a palavra.

Quando chegamos ao exercício 7, surgiram questões dos aprendizes quanto às diferenças culturais entre o Brasil e a Itália; eles fizeram-nos várias perguntas, tais como: “come si dice 'fiado' in italiano?", "come si dice "pagar parcelado'?” e "in Italia si può pagare 'parcelado' come qui ${ }^{91}$ '?.

À primeira questão, não sabíamos responder, pois nunca tínhamos pensado a respeito disso. Por esse motivo, dissemos à classe: "Non lo so, cercherò questa parola e poi ve la dirò la settimana prossima ${ }^{92}$ ". Uma das alunas, que pareceu não ter fícado contente com nossa resposta, imediatamente abriu o dicionário bilíngue português/italiano e procurou a palavra em questão, mas não a encontrou.

Ao terminar a aula, começamos a procurar a palavra "fiado" em dicionários e na internet e não a encontramos. Por isso, no dia seguinte, conversamos com dois de nossos amigos italianos e perguntamos-lhes se há, na língua italiana, alguma expressão informal que significa "a credito", "comprare o vendere a credito". Nossos amigos acharam estranha a pergunta e disseram-nos: "si dice così: a credito".

Tentamos explicar-lhes que, em português, também existem as expressões "comprar ou vender a crédito", mas que elas não são tão informais quanto as expressões "comprar ou vender fiado", e que nos interessava saber se, em italiano, existia uma expressão tão informal como aquelas. Esses nossos dois amigos disseram-nos que não; por isso, na aula seguinte, respondemos a nossos alunos que, na Itália, usam-se,

\footnotetext{
90 Tradução: "O que significa 'etto'?”. Resposta: "Cem gramas”.

91 Tradução das perguntas: "Come se diz 'fiado' em italiano?”, "Come se diz 'pagar parcelado'?", "Na Itália, pode-se pagar parcelado como aqui?".

92 Tradução: "Não sei, vou procurar esta palavra e, depois, direi a vocês na próxima semana".
} 
provavelmente, apenas as expressões "comprare o vendere a credito" e que não há, na língua italiana, uma expressão tão coloquial como a nossa "comprar ou vender fiado".

Então, em tom de gozação, um aluno disse: "na Itália, ninguém vende ou compra fiado; isso deve ser costume de brasileiro mesmo". Perguntamos aos estudantes se eles concordavam com o que dissera esse colega, e todos eles responderam afirmativamente. Como se vê, uma simples questão surgida a partir do trabalho com o folheto de supermercado, favoreceu discussões quanto às diferenças culturais entre o nosso país e o país em que se fala a língua que é objeto de estudo de nossos discentes.

Parece-nos que tais discussões trouxeram, para a sala de aula, a possibilidade de refletirmos, junto aos alunos, sobre as diferenças entre a nossa própria cultura e a culturaalvo e mostrar aos estudantes, na prática, que uma língua pode ser considerada veículo de cultura, pode ser vista como um instrumento que representa e reflete o modo de pensar, de agir e de viver de um povo.

Ademais, esse episódio evidenciou aos alunos um aspecto importante: o material autêntico, muitas vezes, coloca o conhecimento do professor em xeque, porque apresenta a língua em contextos que nem sempre são conhecidos pelo docente e nos lembra que, nós, professores, não somos os detentores do saber e temos sempre algo novo a aprender. Aliás, a nosso ver, este é um dos aspectos mais enriquecedores de nosso trabalho: enquanto ensinamos, temos sempre a possibilidade de aprender; nossos alunos sempre nos ensinam, direta ou indiretamente, algo novo.

No caso específico do ensino-aprendizagem de LE, podemos dizer que, muitas vezes, as dúvidas de nossos discentes fazem-nos aprender palavras e expressões novas, refletir sobre aspectos culturais (da nossa própria cultura e da cultura-alvo) sobre os quais não tínhamos pensado ainda e, dessa forma, ampliar nosso repertório cognitivo, linguístico e cultural.

A segunda e a terceira questões que os alunos nos fizeram não eram difíceis de responder: dissemos-lhes que "pagar parcelado" diz-se, em italiano, "pagare a rate" e que, na Itália, geralmente, fazem-se compras parceladas apenas de bens que custam muito dinheiro, como os automóveis e as casas. Essa informação surpreendeu alguns discentes; uma delas falou: “allora a Italia non si può pagare in rate un viaggio?” e, quando lhe respondemos que possivelmente não, ela afirmou: "è meglio vivere qui in Brasile

\footnotetext{
${ }^{93}$ Tradução: “Então na Itália não se pode pagar em parcelas uma viagem?" / "É melhor viver aqui no Brasil”.
} 
Depois de fazer o exercício 7, cada aluno leu para a classe as respostas dos colegas com quem eles falaram, mencionando as formas de pagamento que cada qual costuma usar para fazer compras no supermercado. Em seguida, fizemos e corrigimos o exercício 8, que parece não ter deixado nenhuma dúvida a nossos estudantes, visto que era uma atividade bastante simples.

No tocante ao exercício 9, propusemos um desafio aos aprendizes: organizados em grupos, cada qual com quatro discentes, eles deveriam preparar a lista de compras e o cardápio em apenas vinte e cinco minutos. Depois, verificaríamos, juntos, qual era a lista mais econômica, ou melhor, qual grupo sabia economizar mais. Retomamos, com eles, o enunciado do exercício, segundo o qual cada grupo poderia gastar, no máximo, setenta euros.

Durante a realização dessa atividade, vários alunos usaram a calculadora de seus celulares para fazer as contas (somar os valores dos produtos contidos no folheto) e pareciam divertir-se, enquanto preparavam a lista de compras, pois riam o tempo todo. Além disso, os aprendizes pareciam muito entretidos e discutiam se deveriam fazer, realmente, primeiro a lista de compras e, depois, o menu; ou se seria melhor, primeiro, decidir quais seriam os pratos a serem preparados, para, depois, resolver quais produtos comprar. Dos três grupos, apenas um decidiu começar a atividade pelo cardápio.

Os discentes estavam tão concentrados na execução da tarefa proposta, que a aula já tinha terminado há cinco minutos, e eles ainda não tinham percebido. Quando lhes dissemos: "Sono già passati $i$ venticinque minuti, anzi, trenta. È finita la lezione. Continueremo a fare le attività luned $\imath^{94}$ ", alguns alunos exclamaram: "Nossa! Já acabou a aula!". Assim, apesar de eles não terem terminado a atividade no tempo proposto por nós, pareceu-nos que eles gostaram bastante do exercício 9.

$\mathrm{Na}$ aula seguinte, os aprendizes pediram dez minutos para concluir a elaboração da lista de compras e do cardápio, pois disseram-nos que queriam finalizá-los. Por isso, demos-lhes o tempo solicitado. Enquanto isso, observávamos a classe e pudemos notar que alguns alunos procuravam, no dicionário, palavras que eles não conheciam, e mostravam-se, como na aula anterior, bastante entretidos e concentrados na atividade.

Decorridos os dez minutos, cada grupo apresentou sua lista de compras e seu menu à classe. $\mathrm{O}$ grupo $1 \mathrm{fez}$ uma lista com produtos que totalizaram sessenta e quatro euros e treze centavos; o segundo grupo gastaria sessenta e cinco euros e noventa e seis

\footnotetext{
${ }^{94}$ Tradução: "Já se passaram os vinte e cinco minutos, ou melhor, trinta. Terminou a aula. Continuaremos fazendo as atividades na segunda-feira".
} 
centavos; e o 3, sessenta e nove euros e oitenta centavos. Dessa maneira, o grupo que soube economizar mais foi o primeiro.

Então, um aluno do grupo 2 fez este comentário: "Il gruppo 1 è 'mão de vaca'. Come si dice 'mão de vaca' in italiano?". Respondemos à turma: "si dice tirchio". Depois, lembramo-nos de uma expressão que se pode usar nesse caso e dissemo-la aos estudantes: "avere il braccio corto o avere il braccino corto ${ }^{95}$ ".

Uma discente quis saber se o significado literal dessa expressão seria: "ter o braço curto". A essa questão, respondemos afirmativamente e explicamos ao grupo que, provavelmente, a expressão quer dizer: "siccome uno ha il braccio corto, non gli arriva alle tasche; quindi questa persona non spende $i$ suoi sold $i^{96}$ ". Para explicar o significado da expressão sem fazer traduções, fizemos gestos na sala de aula: "fingimos" que nossos braços não chegavam aos bolsos. Pareceu-nos que, assim, os alunos entenderam o que lhes disséramos.

Um aprendiz do grupo 2 falou aos colegas do grupo 3: "voi spendete molto"; depois, perguntou-nos: "come si dice 'gastador'?" "Spendaccione" foi a nossa resposta. Após termos lhe respondido, tal aluno disse aos colegas: "voi siete spendaccione!"7". Assim, com essa atividade, pareceu-nos que, além de terem se divertido e interagido com os colegas, nossos estudantes ampliaram seu léxico.

Quanto à atividade 10, os alunos praticaram, em duplas, a leitura do diálogo (que consistia em um convite) e, depois, cada discente releu-o com outro colega. Durante a realização da atividade, caminhamos pela sala de aula e apenas observamos como se dava a interação dos aprendizes entre si, isto é, não fizemos qualquer tipo de intervenção.

Foi muito interessante notar que quatro das seis duplas, em vez de, simplesmente, lerem o diálogo proposto no exercício, resolveram reformulá-lo e reescrevê-lo. Isso parece corroborar os resultados da pesquisa realizada junto às turmas dos cursos extensivos do Italiano no Campus: boa parte dos alunos não gosta de atividades nas quais eles devem, simplesmente, ler um diálogo; preferem que o diálogo seja produzido por eles mesmos.

No tocante à atividade $\mathrm{n}^{\circ} 11$, demos quinze minutos aos estudantes para que, ainda em duplas, elaborassem uma conversa telefônica na qual um deles convidaria o outro para

\footnotetext{
95 Tradução: “O grupo 1 é ‘mão de vaca'”. "Como se diz 'mão de vaca' em italiano?”. Resposta: "Diz-se "tirchio"”. / "Ter o braço curto ou ter o bracinho curto".

96 Tradução: "Como essa pessoa tem o braço curto, este não chega aos bolsos dela; por isso, essa pessoa não gasta o seu dinheiro".

${ }_{97}^{97}$ Tradução das duas frases ditas pelo aluno: "Vocês gastam muito". / "Vocês são gastadores".
} 
um jantar. A primeira pergunta que eles nos fizeram foi esta: "Come si dice 'alô!' in italiano?". Respondemos-lhes: "Pronto!". Novamente, andamos pela sala de aula e, enquanto os discentes faziam a atividade, os observamos e fizemos anotações. Uma das duplas começou o diálogo da seguinte forma:

- Pronto!

- Ciao (nome do aluno)!

- Ciao! Chi è?

- È la (nome da aluna) $)^{98}$.

Ao ouvir a última frase, interrompemos a dupla e dissemos a esses dois alunos: "In portoghese quando parlo con qualcuno al telefono, posso dire 'é a Daniela' ma in italiano dico 'sono Daniela9"," Com essa intervenção, pretendíamos esclarecer aos discentes que, no português de São Paulo, em uma conversa por telefone, é comum o uso do verbo ser na terceira pessoa do singular, conjugado no Presente do Indicativo, seguido do artigo definido para identificar a pessoa que fala. Mas, em italiano, isso não é possível: nesse idioma, usa-se o verbo essere na primeira pessoa do singular no Presente do Indicativo e sem o artigo. Depois, fizemos esse esclarecimento à classe toda, mas, procuramos não usar a nomenclatura gramatical, para não dificultar a explicação.

Transcorridos os quinze minutos, solicitamos que cada dupla apresentasse seu diálogo à classe. Para conferir um grau maior de autenticidade à apresentação, pedimos que os aprendizes de cada dupla ficassem de costas um para o outro, de modo que não pudessem se ver e demos a cada aluno um celular, para que eles realmente simulassem uma conversa telefônica. A ideia era a de que os estudantes notassem que, por telefone, é necessário verbalizar tudo, isto é, não é possível, por exemplo, fazer gestos ou expressões faciais para que o ouvinte compreenda a mensagem.

Nossa ideia foi bem recebida pelos alunos, que, ao se apresentarem, deram muitas risadas. Alguns deles tinham escrito o diálogo e, no momento da apresentação, decidiram apenas lê-lo; outros, porém, como o tinham feito apenas oralmente, fizeram improvisações na hora de apresentá-lo à classe.

Foi interessante ver que, nos diálogos lidos e, também, nos improvisados, os estudantes usaram corretamente expressões como: “(Nome do aluno) non c' e’” e "aspetta

\footnotetext{
98 Tradução do diálogo: - Alô!

- Oi, (nome do aluno)!

- Oi! Quem é?

- É a (nome da aluna).
}

99 Tradução: "Em português, quando falo com alguém por telefone, posso dizer 'é a Daniela', mas, em italiano, digo "sou Daniela'". 
un po'100". Usaram, além disso, um tempo verbal que ainda não tínhamos estudado: o passato prossimo (pretérito perfeito). É o que se vê nesta frase dita por um aluno: "Ho invitato alcuni amici, anche tu vuoi venire ${ }^{101}$ ".

No que concerne ao exercício 12, cada discente teve de escrever um e-mail no qual convidasse outro amigo para um jantar. Os alunos já tinham praticado oralmente o convite, por meio da leitura/reelaboração do diálogo do exercício 10 e por meio da conversa telefônica proposta na atividade 11. Na 12, eles deveriam fazer a transposição do convite feito oralmente para a linguagem escrita: tratava-se de escrever um e-mail informal bastante simples.

Depois de fazerem essa atividade, solicitamos que cada estudante lesse seu texto à classe. Dos doze alunos, cinco usaram a palavra "senti"102", típica de interações orais. Talvez a tenham usado pelo fato de ela estar presente no diálogo da atividade 10, que eles já tinham lido e praticado. Explicamos-lhes que tal palavra é bastante adequada em uma conversação informal, mas não seria adequada em um e-mail, uma vez que este é um gênero escrito. Assim, com esse exercício, atingimos o objetivo de fazer os alunos refletirem um pouco sobre as diferenças entre a língua oral e a escrita.

Em suma, o trabalho de didatização do gênero folheto de supermercado produziu bons resultados em nossa sala de aula: por meio das atividades propostas, os alunos praticaram as quatro habilidades primárias, exercitaram estruturas linguísticas, ampliaram seu repertório lexical, interagiram uns com os outros, refletiram sobre aspectos interculturais e sobre diferenças entre o oral e o escrito. Portanto, podemos dizer que todos os objetivos que pretendíamos atingir, com tais atividades, junto à nossa turma de nível I foram alcançados.

\subsection{A escolha do gênero textual história em quadrinhos}

Muitos professores de italiano, geralmente, solicitam que, nos níveis iniciais de estudo da língua-alvo, os estudantes leiam livros de leitura graduada, isto é, livros cuja leitura é facilitada para estrangeiros. Esse tipo de livro tem, provavelmente, a sua

\footnotetext{
100 Tradução: “(Nome do aluno) não está”. / "Espera um pouco!”.

101 Tradução: "Convidei alguns amigos, você também quer vir?".

102 Tradução: "Ouça!”.
} 
utilidade; no entanto, é, praticamente, um material didático e, portanto, não apresenta, normalmente, gêneros textuais com que os alunos se depararão fora da sala de aula.

Como é sabido, não há materiais perfeitos, completos ou ideais, mas há materiais que atendem aos interesses dos alunos. Por isso, para escolher os materiais a serem usados nas aulas, é importante conversar com os aprendizes, para descobrir quais são os interesses deles. Com o intuito de conhecer nossos estudantes, dedicamos, antes e depois de cada aula, alguns minutos para conversas com cada aluno.

Nessas conversas, percebemos que a maioria dos discentes tinha uma vontade em comum: a de ler algum texto em italiano que não fizesse parte do livro didático. Por esse motivo, refletimos bastante para encontrar um texto que pudesse ser lido por alunos do nível principiante, mas que não tivesse sido escrito, adaptado ou simplificado para estrangeiros.

Nossa ideia era a de encontrar um texto autêntico que pudesse ser lido por nossos aprendizes, mesmo eles tendo pouco conhecimento da língua-alvo; pretendíamos, também, que esse texto contribuísse para a ampliação do repertório de conhecimentos linguísticos e culturais de nossos estudantes. Após algum tempo de reflexão, tendo em vista essa vontade dos alunos e, também, o fato de não querermos trabalhar com livros de leitura facilitada, decidimos trabalhar com o gênero história em quadrinhos e selecionamos algumas historinhas do lobo Alberto.

Segundo Júdice (2005, p. 41), a história em quadrinhos consiste em um "gênero icônico-verbal narrativo cuja progressão temporal se organiza quadro a quadro, contendo elementos típicos como desenhos, quadros, balões e legendas onde é inserido o texto verbal".

Há diversos motivos para se utilizar esse material autêntico nas aulas de língua estrangeira, tais como:

- a universalidade desse gênero, o qual costuma ser apreciado em todo o mundo;

- a acessibilidade dos textos nele configurados, a qual decorre da associação entre a imagem e a palavra - tendo em vista que, segundo a perspectiva neurolinguística, $80 \%$ das informações chegam ao cérebro por meio da visão, a utilização desse gênero textual pode ser muito profícua nas aulas de uma língua-alvo. De acordo com tal perspectiva, os elementos imagéticos são mais adaptáveis à compreensão do que os verbais. Assim, quando as imagens são associadas à linguagem escrita, permitem aos estudantes a construção de sentidos com base nelas, bem como o estabelecimento de 
relações entre elas e o texto escrito, mesmo que os alunos estejam em um nível inicial de aprendizagem do idioma;

- a possibilidade de refletir sobre a língua em uso e sobre as relações entre as modalidades oral e escrita da língua estrangeira - a história em quadrinhos é um gênero textual em que são reproduzidos, por escrito, diálogos; portanto buscam representar a língua oral, mesmo sendo textos escritos;

- a ludicidade presente nesse gênero textual - geralmente, aspectos humorísticos estão presentes na história em quadrinhos; por essa razão, sua leitura é, muitas vezes, relacionada a momentos de entretenimento, diversão e lazer.

\subsubsection{A didatização de algumas histórias em quadrinhos: a seleção dos textos e a definição dos objetivos}

Esse gênero textual tem a função social de entreter e divertir os leitores para os quais ele foi produzido, ou seja, os falantes nativos de uma determinada língua: uma vez que o autor e os leitores compartilham a mesma língua e a mesma cultura, a história em quadrinhos cumpre, geralmente, tal função.

Todavia, quando empregada na sala de aula de LE, a história em quadrinhos somente cumprirá esse propósito, se os aprendizes estrangeiros a entenderem. Ademais, ao ser utilizado no processo de ensino-aprendizagem de uma língua-alvo, o gênero em questão deixa de ter apenas a função referente ao entretenimento e à diversão, podendo tornar-se um instrumento de ensino-aprendizagem linguística e cultural.

Para que a história em quadrinhos entretenha e divirta os estudantes e para que ela se torne um instrumento de ensino-aprendizagem da língua estrangeira, é necessário o trabalho de didatização efetuado pelo professor.

Como já foi dito, a primeira etapa do processo de didatização de um material autêntico refere-se à sua seleção: escolhemos o gênero textual história em quadrinhos para trabalharmos com nossos alunos de nível I devido aos motivos anteriormente mencionados.

Selecionado o gênero, tínhamos de decidir quais histórias em quadrinhos utilizaríamos com a nossa turma e, para isso, levamos em conta o seguinte critério: tendo em vista que o texto autêntico é um produto da língua e da cultura-alvo, seria importante, a nosso ver, que as histórias escolhidas fossem italianas, isto é, não nos interessavam, por 
exemplo, tirinhas da Disney ou da turma da Mônica traduzidas para o italiano. Mesmo traduzidas, tais historinhas trazem consigo aspectos linguísticos e culturais de seus países de origem.

Assim, como nosso contexto de trabalho docente diz respeito ao italiano LE, e não ao inglês ou ao português, interessava-nos trabalhar tirinhas escritas originalmente em língua italiana. Foi assim que optamos por trabalhar, junto ao nosso grupo, as histórias do lobo Alberto, personagem criado por Silver (nome artístico de Guido Silvestri) em dezembro de 1973 e que teve suas histórias publicadas pela primeira vez em fevereiro de 1974.

Esse personagem é o protagonista das histórias em quadrinhos homônimas e, embora tenha sido criado há quase trinta anos, ainda hoje é bastante conhecido e apreciado na Itália. Em 2010, a editora Oscar Mondadori publicou um livro com uma coletânea de histórias do lobo Alberto, produzidas em diversos anos. O livro intitula-se Lupo Alberto. T. V. B. Lupo! e contém mais de trezentas historinhas, cada qual com uma página. Foi esse o material que usamos para desenvolver um trabalho com os estudantes do nível I.

Antes de selecionar as histórias a serem trabalhadas com nossos aprendizes, definimos os objetivos a serem atingidos por eles com a realização desse trabalho. Tais objetivos eram os seguintes:

- Despertar o interesse e a curiosidade pelas histórias em quadrinhos italianas.

- Conhecer alguns personagens dessas histórias.

- Desenvolver a compreensão escrita.

- Ampliar o repertório linguístico e cultural.

- Revisar conteúdos lexicais, gramaticais e comunicativos estudados durante o semestre.

Escolhido o livro e definidos os objetivos a serem alcançados, selecionamos algumas histórias: depois de ler a maioria dos textos contidos nele, escolhemos três para trabalhar com nossos alunos. Para fazer essa seleção, baseamo-nos nos seguintes critérios:

- o alto grau de familiaridade lexical - optamos por historinhas que continham palavras que, em sua maioria, já eram conhecidas pelos discentes;

- os conteúdos pertinentes ao programa de estudo do nível I do Italiano no Campus - os três textos selecionados apresentavam conteúdos que se estudam no primeiro nível do IC, como: o tratamento formal e informal, os verbos no presente do indicativo, os pronomes diretti etc; 
- a apresentação de situações já trabalhadas nas aulas - nas três histórias, mostravam-se situações relacionadas a atividades que já tínhamos feito nas aulas.

Esses critérios baseiam-se nos postulados de Ausubel (1968), conforme os quais, é necessário e importante trabalhar com os conhecimentos prévios dos alunos; ou seja, essas histórias em quadrinhos permitiriam, aos discentes, resgatar e rever alguns conteúdos que eles já tinham estudado no nível I do curso e que, portanto, já faziam parte, provavelmente, do repertório cognitivo dos aprendizes. A nosso ver, essa seria uma maneira de favorecer a aprendizagem significativa da língua italiana por nossos estudantes. Mais adiante, discorreremos sobre o trabalho com as histórias escolhidas. Agora, abordaremos as atividades realizadas antes desse trabalho.

\subsubsection{A didatização de algumas histórias do lobo Alberto - as atividades propostas e alguns relatos de prática}

Tendo em vista que os alunos não conheciam as histórias do lobo Alberto, fizemos-lhes uma apresentação desse e de outros personagens de tais histórias: solicitamos-lhes que lessem, em casa, as páginas iniciais do livro ${ }^{103}$, que consistiam em uma entrevista ao autor desses textos e em uma descrição dos principais personagens da fazenda McKenzie.

Fizemos cópias dessas dezesseis páginas do livro e entregamo-las aos aprendizes no começo de maio de 2010, esclarecendo-lhes que deveriam lê-las, em casa, até o final daquele mês. Orientamo-los a fazer, ao menos, duas leituras do texto: a primeira sem recorrer ao dicionário e procurando ater-se ao sentido geral da entrevista e das descrições; a segunda, por sua vez, com o auxílio do dicionário e até mesmo da professora, com o intuito de compreender detalhes dos textos. Embora tenhamos solicitado que os alunos lessem o texto em casa, explicamos-lhes que poderiam recorrer a nós, caso não conseguissem solucionar suas dúvidas apenas com o dicionário.

No final de maio, antes de conversarmos sobre a entrevista a Silver e as descrições dos personagens, propusemos à turma que assistíssemos ao vídeo Lupo Alberto - Storie Brevi $^{104}$ (um vídeo com duração de dez minutos e que mostra doze historinhas), para que

\footnotetext{
${ }^{103}$ As páginas cuja leitura foi solicitada aos alunos encontram-se ao final deste trabalho: cf. anexo D.

104 Vídeo disponível em: http://www.youtube.com/watch?v=hSYb56CqjI8. Último acesso em 01 de maio de 2012.
} 
os estudantes pudessem ter uma compreensão global das histórias e entender melhor as relações entre os personagens principais, como: Alberto, Marta, Mosè, Enrico e Cesira.

Escolhemos o vídeo por se tratar de histórias em quadrinhos em um suporte não convencional, isto é, a internet. No vídeo, não eram mostrados desenhos animados feitos a partir das tirinhas do lobo Alberto, mas sim, as próprias tirinhas, que diferiam das mostradas no papel por um detalhe: o fato de os personagens terem vozes, que podiam ser ouvidas, enquanto víamos e líamos as histórias.

Antes de assistirmos a essas histórias em quadrinhos, esclarecemos aos alunos que veríamos apenas os quatro primeiros minutos do vídeo, ou seja, assistiríamos somente às primeiras histórias. Esclarecemos-lhes, também, que não era importante compreender tudo o que eles veriam no vídeo, pois nosso objetivo consistia em fazê-los conhecer melhor os personagens principais. Mas, enquanto assistíamos às histórias, os aprendizes quiseram ver todas e, depois, pediram para revê-las; por isso, assistimos duas vezes ao vídeo todo, o que parece indicar que eles se interessaram pelas histórias.

Após termos visto o vídeo, conversamos sobre ele. Os alunos disseram ter entendido a maioria das histórias, mas não todas. No entanto, como o objetivo dessa parte da aula não consistia na compreensão detalhada das histórias, e sim na compreensão geral delas e na percepção das relações entre os personagens principais, é possível dizer que nossos propósitos foram atingidos.

Em seguida, conversamos sobre a entrevista ao autor das histórias do lobo Alberto e sobre a descrição dos personagens. Percebemos que os estudantes entenderam bem, tanto a entrevista quanto a descrição, pois nos disseram, com suas próprias palavras, o que tinham compreendido; e o que eles disseram era exatamente o que estava escrito no livro. No entanto, dos dez alunos presentes nessa aula, seis falaram em português acerca do texto. Mas, como o objetivo principal dessa conversa era a compreensão textual, permitimos o uso da língua materna. Apesar disso, alguns aprendizes esforçaram-se para falar em italiano e conseguiram expressar oralmente, na língua-lavo, o que tinham entendido das páginas lidas.

$\mathrm{Na}$ aula seguinte, ainda com o objetivo de trabalhar a compreensão do texto, perguntamos, aos discentes, quem o lobo Alberto representava, e, com base na leitura da entrevista a Silver, responderam-nos: "siamo noi ${ }^{105}$ ". Depois, lemos para eles uma frase retirada de um texto da internet ${ }^{106}$ o qual lhes enviamos, por e-mail, ao final daquela aula:

\footnotetext{
105 Tradução: "Somos nós”. (Na entrevista lida, Silver afirma que o lobo Alberto é cada um de nós).

${ }^{106}$ Texto disponível em: http://it.wikipedia.org/wiki/Lupo_Alberto. Último acesso em 06 de maio de 2012.
} 
"Lupo Alberto riprende la figura dell'uomo comune, con un obiettivo nella vita e una certa dose di sfortuna ${ }^{107}$,.

Com base na frase acima e na resposta de Silver à questão "Quem é o lobo Alberto?", elaboramos um jogo com cuja realização pretendíamos atingir, junto aos aprendizes, os seguintes objetivos:

- Desenvolver a compreensão escrita.

- Ampliar o repertório lexical a partir dos atributos dos personagens das histórias do lobo Alberto (atributos mencionados nas páginas do livro as quais os alunos leram).

- Favorecer a interação dos aprendizes entre si.

- Propiciar-lhes um momento lúdico.

O jogo que criamos chama-se "Lupo Alberto" e baseia-se na ideia de que esse personagem pode ser cada um de nós, isto é, de que ele representa as pessoas em geral.

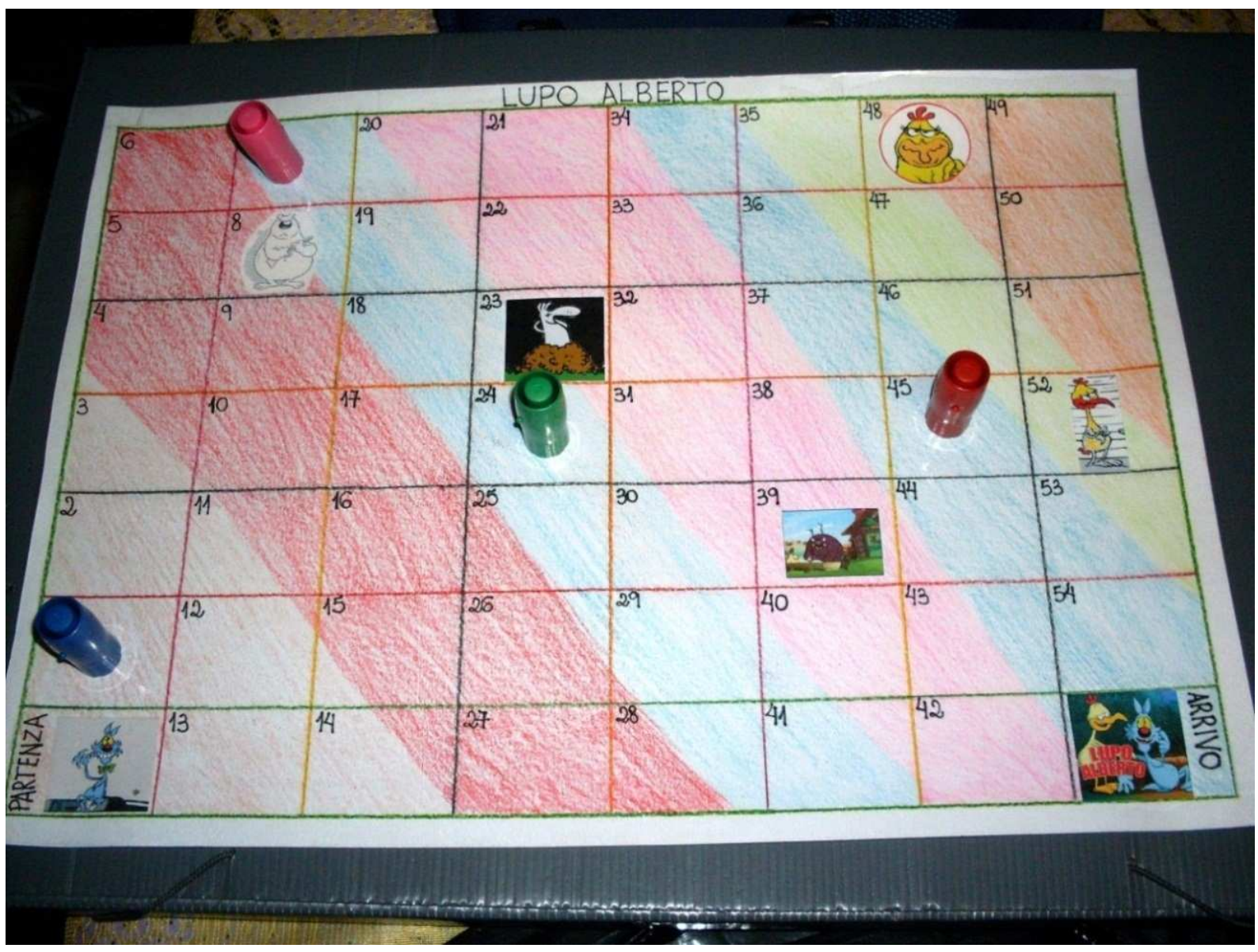

Figura 2 - O tabuleiro do jogo de percurso que confeccionamos

107 "Lobo Alberto retoma a figura do homem comum, com um objetivo na vida e certa dose de azar" (tradução nossa). 
Trata-se de um jogo de percurso no qual os alunos têm de responder perguntas referentes à entrevista a Silver e às descrições dos personagens principais da fazenda Mckenzie (contidas nas páginas que os aprendizes leram em casa e sobre as quais conversamos na sala de aula). O objetivo consiste em levar Alberto até Marta, isto é, possibilitar que o casal se encontre. A seguir, mostramos tais questões, que foram colocadas na parte interna das cartas do jogo:

Tabela 2 - Perguntas do jogo "Lupo Alberto" 108 "

\begin{tabular}{|c|c|c|}
\hline $\begin{array}{l}\text { Come si chiama l'autore di } \\
\text { Lupo Alberto? } \\
\text { a) Sergio Endrigo } \\
\text { b) Guido Silvestri } \\
\text { c) Eugenio Montale }\end{array}$ & $\begin{array}{l}\text { Lupo Alberto è un } \\
\text { personaggio... } \\
\text { a) tranquillo } \\
\text { b) nervoso } \\
\text { c) rompiscatole }\end{array}$ & $\begin{array}{l}\text { Come si chiama } \\
\text { fidanzata di Alberto? } \\
\text { a) Alice } \\
\text { b) Cesira } \\
\text { c) Marta }\end{array}$ \\
\hline $\begin{array}{l}\text { Chi è la migliore amica di } \\
\text { Marta? } \\
\text { a) Alice } \\
\text { b) Cesira } \\
\text { c) Silvietta }\end{array}$ & $\begin{array}{l}\text { Dove abitano i personaggi? } \\
\text { a) in una foresta } \\
\text { b) in una fattoria } \\
\text { c) in un bosco }\end{array}$ & $\begin{array}{l}\text { Chi è Alcide? } \\
\text { a) il marito di Cesira } \\
\text { b) l'intellettuale del } \\
\text { gruppo } \\
\text { c) il nemico di Alberto }\end{array}$ \\
\hline $\begin{array}{l}\text { Qual è il personaggio che } \\
\text { si intende di fisica e di } \\
\text { meteorologia? } \\
\text { a) Enrico, la talpa } \\
\text { b) Lodovico, il cavallo } \\
\text { c) Alfredo, } \\
\text { tacchino }\end{array}$ & $\begin{array}{l}\text { Cesira è la moglie di... } \\
\text { a) Alberto } \\
\text { b) Mosè } \\
\text { c) Enrico }\end{array}$ & $\begin{array}{l}\text { Cesira sa... } \\
\text { a) cucinare bene } \\
\text { b) cantare bene } \\
\text { c) scrivere bene }\end{array}$ \\
\hline $\begin{array}{l}\text { Qual è l'animale più } \\
\text { ottimista della fattoria? } \\
\text { a) Krug, il toro } \\
\text { b) Joseph, il papero } \\
\text { c) Marta, la gallina }\end{array}$ & $\begin{array}{l}\text { Chi è il compagno } \\
\text { inseparabile di Glicerina? } \\
\text { a) Lodovico, il cavallo } \\
\text { b) Marta, la gallina } \\
\text { c) Alcide, il maiale }\end{array}$ & $\begin{array}{l}\text { Chi sono i due personaggi } \\
\text { irascibili della fattoria? } \\
\text { a) Krug e Mosè } \\
\text { b) Glicerina e Alcide } \\
\text { c) Lodovico e Alberto }\end{array}$ \\
\hline $\begin{array}{l}\text { Qual è il grande desiderio } \\
\text { di Marta? } \\
\text { a) avere una casa } \\
\text { b) sposarsi } \\
\text { c) diventare ricca }\end{array}$ & $\begin{array}{l}\text { Chi ostacola l'amore tra } \\
\text { Alberto e Marta? } \\
\text { a) Odoardo } \\
\text { b) Mosè } \\
\text { c) Alcide }\end{array}$ & $\begin{array}{l}\text { Odoardo, il cugino di } \\
\text { Marta, è molto: } \\
\text { a) antipatico } \\
\text { b) bello } \\
\text { c) simpatico }\end{array}$ \\
\hline $\begin{array}{l}\text { Lupo Alberto è destinato } \\
\text { allo scontro con Mosè. } \\
\text { Cosa significa la parola } \\
\text { sottolineata? } \\
\text { a) conflitto } \\
\text { b) problema } \\
\text { c) amicizia }\end{array}$ & $\begin{array}{l}\text { Cesira è molto assennata, } \\
\text { cioè è molto... } \\
\text { a) triste } \\
\text { b) allegra } \\
\text { c) prudente }\end{array}$ & $\begin{array}{l}\text { Enrico è un po' cialtrone, } \\
\text { quindi è un po'... } \\
\text { a) simpatico } \\
\text { b) prudente } \\
\text { c) poltrone }\end{array}$ \\
\hline
\end{tabular}

${ }^{108}$ A tradução das perguntas que elaboramos encontra-se ao final desta dissertação: cf. apêndice G. 


\begin{tabular}{|c|c|c|}
\hline $\begin{array}{l}\text { Glicerina è l'animale più } \\
\text { sciocco della fattoria, } \\
\text { allora è... } \\
\text { a) imbecille } \\
\text { b) intelligente } \\
\text { c) sincero }\end{array}$ & $\begin{array}{l}\text { Krug è un personaggio } \\
\text { manesco, ciò vuol dire che } \\
\text { gli piace usare le "mani" } \\
\text { per... } \\
\text { a) fare il solletico } \\
\text { b) picchiare } \\
\text { c) accarezzare }\end{array}$ & $\begin{array}{l}\text { Marta è una gallina vivace, } \\
\text { ossia è... } \\
\text { a) antipatica } \\
\text { b) dolce } \\
\text { c) dinamica }\end{array}$ \\
\hline $\begin{array}{l}\text { Mosè è un paladino } \\
\text { dell'ordine costituito. Cosa } \\
\text { vuol dire la parola } \\
\text { sottolineata? } \\
\text { a) difensore } \\
\text { b) attacante } \\
\text { c) nemico }\end{array}$ & $\begin{array}{l}\text { Lupo Alberto vive... } \\
\text { a) con gli amici } \\
\text { b) con Marta } \\
\text { c) da solo }\end{array}$ & $\begin{array}{l}\text { Mosè è un personaggio } \\
\text { irascibile, cioè... } \\
\text { a) è gentile } \\
\text { b) è simpatico } \\
\text { c) è rabbioso }\end{array}$ \\
\hline
\end{tabular}

Cada uma dessas perguntas foi elaborada e escrita por nós em um cartãozinho. Os itens em vermelho são as respostas corretas. O jogo era composto pelos seguintes itens: um tabuleiro, vinte e quatro cartas com questões, cinco cartas com observações que interfeririam no andamento do jogo, um dado e quatro peões (um de cada cor ${ }^{109}$ ).

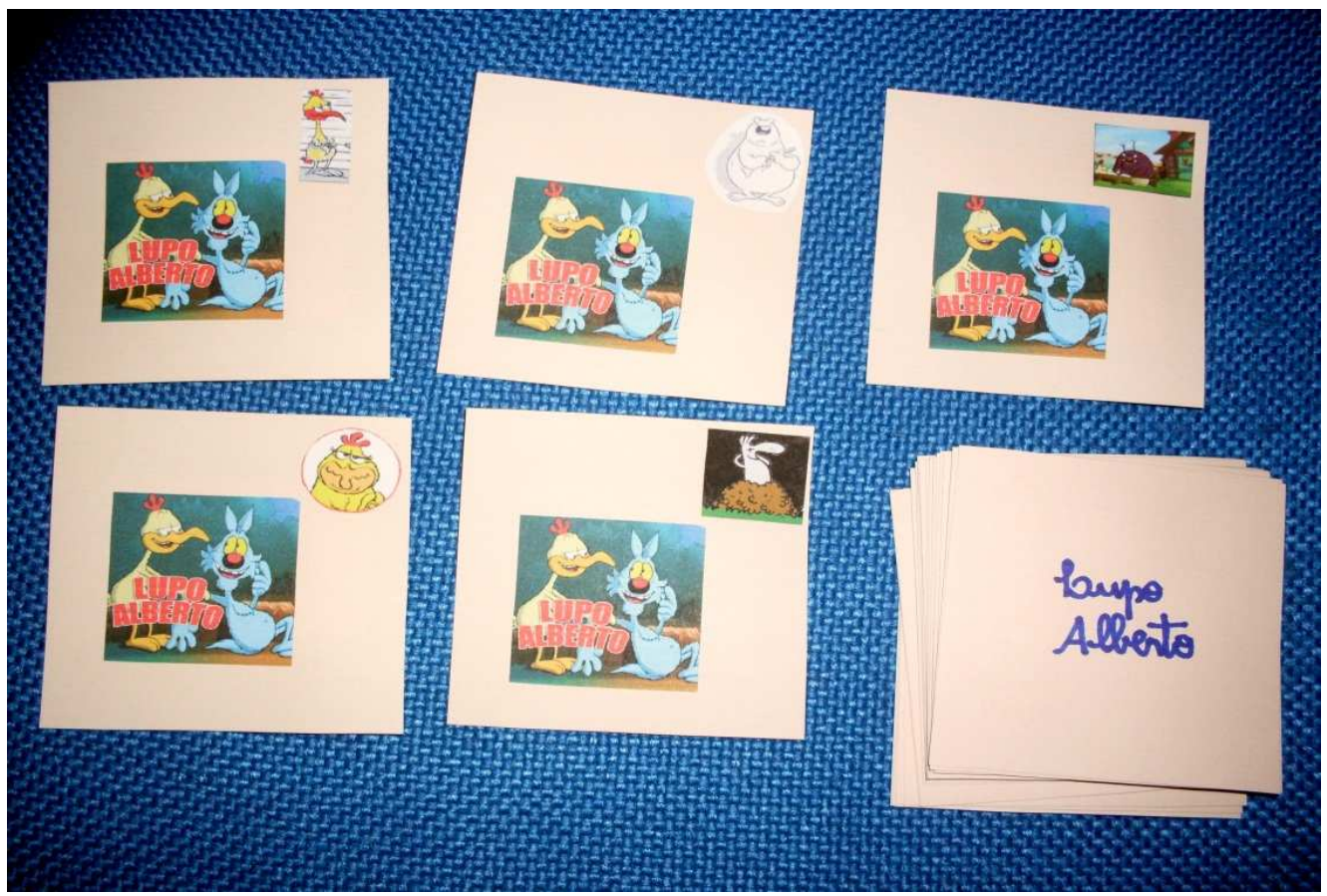

Figura 3 - As cartas do jogo (parte externa)

As observações escritas nas cartas que continham ilustrações eram as seguintes:

- “Attento! Se Mosè ti vede, guai a te! Quindi torna indietro di due caselle"110".

\footnotetext{
${ }^{109}$ Cf. figura 2.

${ }^{110}$ As frases contidas em todas as cartas do jogo são de nossa autoria. A seguir, traduzimos as frases escritas nas cartas que têm ilustrações. São respectivamente:

- Atenção! Se Mosè o vir, você terá problemas. Por isso, volte duas casinhas.
} 
- 'Ecco Enrico, la talpa! Vuole chiacchierare un po' con te, ma siccome hai fretta perché Marta ti aspetta, salutalo e va' via. Allora avanza di una casella".

- "Marta è arrabbiata perché tu, lupo Alberto, sei in ritardo. Dunque, sbrigati! Avanza di una casella".

- "Alice si sta truccando per uscire. Forse andrà da Marta... Che palle! Vuoi arrivare a casa di Marta prima di Alice, no? Allora sbrigati! Avanza di due caselle".

- 'Oddio! Krug, il toro, si è svegliato... Non farti vedere da lui! Nasconditi! Torna indietro di una casella".

Para jogar "Lupo Alberto", dividimos a classe em grupos de quatro alunos, portanto eram três grupos. Demos a cada grupo os itens já mencionados e explicamoslhes as regras do jogo: em cada grupo, os aprendizes deveriam decidir quem o iniciaria.

Decidido isso, o primeiro aluno deveria jogar o dado. Mas, para avançar, no percurso, o número de casas indicado pelo dado, esse estudante deveria, primeiramente, responder uma questão que lhe seria feita pelo segundo aluno. Este deveria, então, tirar uma carta e fazer a pergunta ao colega. Se tal colega a respondesse corretamente, poderia avançar o número de casas indicado pelo dado. Se errasse a resposta, deveria permanecer na casinha onde se encontrava naquele momento.

Depois, o segundo jogador lançava o dado e respondia uma questão feita pelo terceiro; este respondia uma pergunta feita pelo quarto e, assim, sucessivamente. Quando um discente parasse em uma casa que continha uma ilustração, deveria ler a carta que apresentava o desenho igual ao dessa casa e seguir as indicações mencionadas na carta: por exemplo, avançar uma casinha, voltar duas casas etc. $\mathrm{O}$ vencedor seria aquele que chegasse primeiro à casa de Marta, ou melhor, aquele que conseguisse levar, primeiro, o lobo Alberto à casa de sua namorada.

A atividade foi recebida com entusiasmo pelo grupo; eles ficaram tão entretidos com o jogo, que, após tê-lo concluído, dois dos três grupos quiseram jogá-lo novamente, o que parece indicar que a classe gostou da atividade. Aliás, nove alunos disseram-nos, ao

- Aqui, está Enrico, a toupeira! Ele quer conversar um pouco com você, mas como você está com pressa, porque Marta o espera, cumprimente-o e vá embora. Então, avance uma casa.

- Marta está com raiva, porque você, lobo Alberto, está atrasado. Portanto, apresse-se! Avance uma casinha.

- $\quad$ Alice está se maquiando para sair. Talvez vá à casa da Marta... Que saco! Você quer chegar à casa da Marta antes da Alice, não é? Então apresse-se! Avance duas casas.

- Ó Deus! Krug, o touro, acordou... Não deixe que ele veja você! Esconda-se! Volte uma casinha. 
final da aula, que gostaram bastante desse jogo e que gostariam de ter mais atividades desse tipo. No total, a atividade durou cerca de quarenta minutos.

$\mathrm{Na}$ aula seguinte, finalmente, começamos a trabalhar com as três histórias em quadrinhos que mencionamos anteriormente. A primeira foi uma história da página 26 do livro já citado:
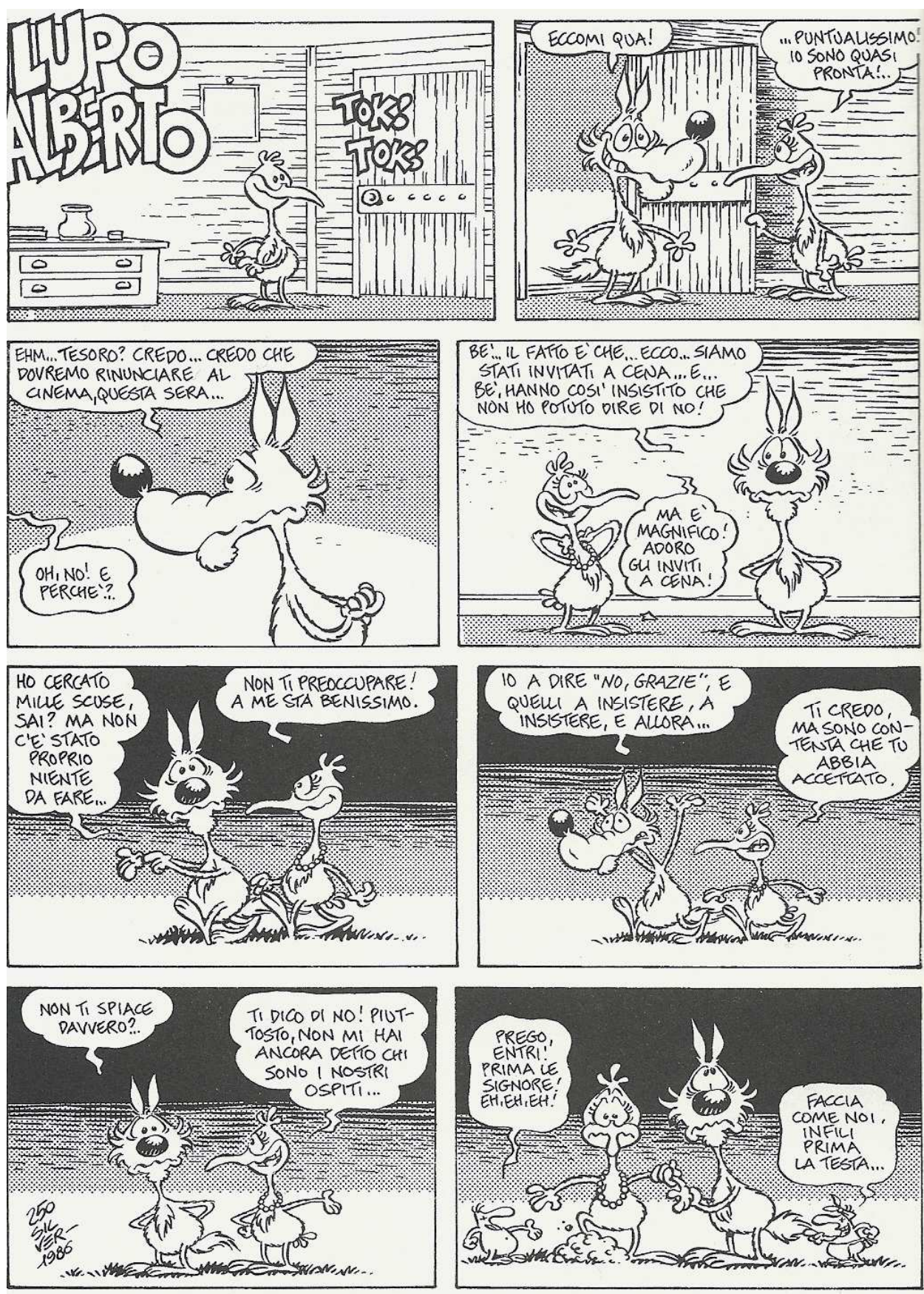

26

Figura 4 - A primeira historinha ${ }^{111}$ que trabalhamos com nossa turma

\footnotetext{
${ }^{111}$ Tradução da história:
} 
Primeiramente, distribuímos cópias desse texto aos alunos e solicitamos-lhes que o lessem. Demos-lhes cinco minutos para fazer a leitura. Depois, propusemos-lhes a seguinte atividade: a dramatização dos diálogos. Para fazê-la, os estudantes organizaramse em grupos de quatro componentes, já que a história tem quatro personagens: Alberto, Marta, Cesira e Enrico. Essa atividade foi realizada em cerca de dez minutos. Em seguida, solicitamos aos discentes que, em duplas, respondessem as seguintes questões que elaboramos:

1) Quali sono i personaggi di queste strisce?

a) ( ) Marta, Alberto, Lodovico e Mosè

b) ( ) Marta, Alberto, Cesira e Enrico

c) ( ) Marta, Alberto, Alice e Alcide

2) Alberto dice a Marta che non potranno andare al cinema perché...

a) ( ) lui deve lavorare.

b) ( ) lui vuole andare al ristorante.

c) ( ) li hanno invitati a cena.

3) La coppia andrà a mangiare a casa di...

a) ( ) Enrico e Cesira

b) ( ) Alice

c) ( ) Alcide e Glicerina

4) Cos'è la casa degli ospiti?

Quadrinho 1 - Toc! Toc!

Quadrinho 2 - Alberto: Estou aqui! Marta: ... Pontualíssimo! Eu estou quase pronta!...

Quadrinho 3 - Alberto: Ei... Tesouro? Acredito... Acredito que teremos de renunciar ao cinema esta noite... Marta: Oh, não! E por quê?...

Quadrinho 4 - Alberto: Bem... O fato é que... Então... Fomos convidados para um jantar... E... Bem, insistiram tanto que não pude dizer não!

Marta: Mas é magnífico! Adoro convites para jantar!

Quadrinho 5 - Alberto: Procurei mil desculpas, sabe? Mas não houve mesmo nada a fazer... Marta: Não se preocupe! Para mim, está tudo bem.

Quadrinho 6 - Alberto: Eu dizendo “não, obrigado!", e eles insistindo, insistindo, e então... Marta: Acredito em você, mas estou contente por você ter aceitado.

Quadrinho 7 - Alberto: Você não se incomoda mesmo? Marta: Já disse que não! Aliás, você ainda não me disse quem são os nossos anfitriões...

Quadrinho 8 - Enrico: Por favor, entre, senhora! Primeiro, as senhoras! Eh, eh, eh! Cesira: Faça como nós, senhora, enfie primeiro a cabeça... 

a) ( ) un albero
b) ( ) un buco
c) ( ) un pollaio

5) Nell'ultima vignetta si usa il trattamento confidenziale o formale? Quali sono le parole che ti hanno aiutato a capirlo? Scrivile sotto:

6) Qual è il "problema" dell'invito?

As quatro primeiras eram questões de múltipla escolha, que visavam à compreensão da história lida. Por sua vez, a pergunta $\mathrm{n}^{\mathrm{o}} 5$ dizia respeito ao uso do tratamento formal, conteúdo bastante estudado durante o semestre. Chamamos a atenção dos alunos para o fato de Enrico e Cesira usarem o tratamento formal ao falarem com Alberto e Marta e vice-versa. Esclarecemos-lhes que isso é recorrente nas histórias em que aparecem os quatro personagens, o que parece indicar que, embora morem na mesma fazenda, eles mantem uma relação de formalidade.

Já a questão 6 referia-se ao convite que Marta e Alberto receberam: esse convite tinha um inconveniente, que produzia um efeito humorístico no texto. Os alunos deviam responder qual era o inconveniente. Demos cerca de quinze minutos para que eles respondessem todas as questões e, em seguida, fizemos a correção destas. Para isso, um aluno de cada dupla leu sua resposta. A única pergunta em cujas respostas tivemos de fazer pequenas correções foi a última. Um discente respondeu essa questão da seguinte forma: "il problema è che Enrico e Cesira abitano in basso della terra". Dissemos-lhe que eram necessários pequenos ajustes na resposta, que poderia ser: “(...) abitano sottoterra” ou “(...) abitano in un buco ${ }^{112 "}$.

A segunda história em quadrinhos que trabalhamos com nosso grupo foi a da página 152 do mesmo livro:

\footnotetext{
112 Tradução da frase do aluno: O problema é que Cesira e Enrico moram em baixo da terra. Tivemos de corrigir a frase, porque em italiano "em baixo da terra" diz-se "sottoterra". Também apresentamos aos alunos outra possibilidade de resposta, que se traduz desta forma: "moram em um buraco".
} 

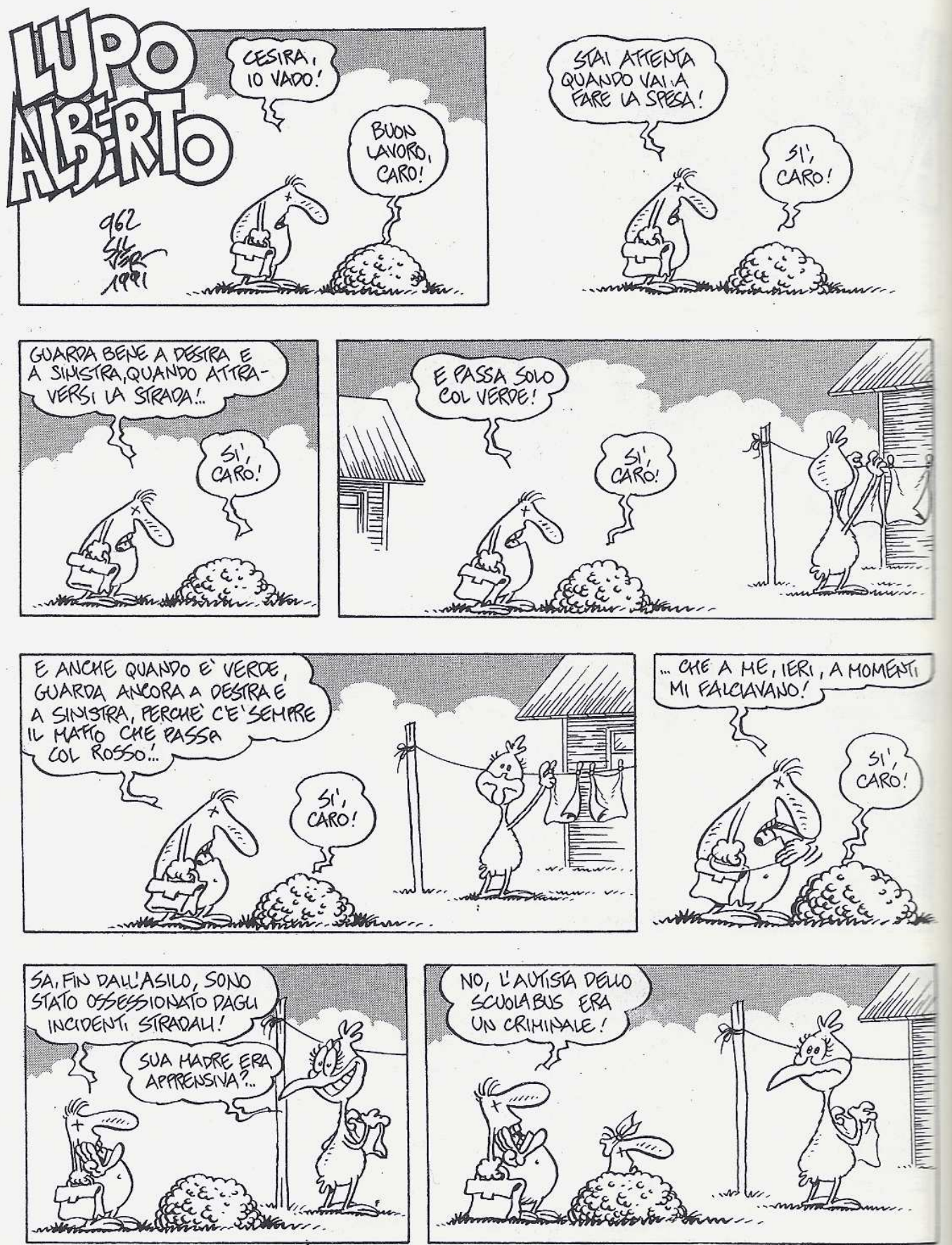

Figura 5 - A segunda história ${ }^{113}$ do lobo Alberto trabalhada com nossos alunos

\footnotetext{
${ }^{113}$ Tradução da história:

Quadrinho 1 - Enrico: Cesira, eu vou!

Cesira: Bom trabalho, querido!

Quadrinho 2 - Enrico: Fique atenta quando for fazer compras!

Cesira: Sim, querido!
}

Quadrinho 3 - Enrico: Olhe bem para a direita e para a esquerda, quando atravessar a rua!... 
Entregamos aos estudantes cópias dessa historinha, mas sem algumas das falas dos personagens: retiramos do texto seis falas destes. A atividade proposta a partir da história consistia justamente em identificar quais foram as frases ditas por cada personagem, de modo a manter a coerência dos diálogos estabelecidos entre Enrico e Cesira e entre ele e Marta. Para fazer tal exercício, os alunos tinham de associar as frases às imagens e esforçar-se por compreender a história, para construir o sentido do texto. Abaixo, transcrevemos a atividade que propusemos:

\section{Chi ha detto queste frasi?}

Guarda la storia a fumetti di lupo Alberto e scrivi davanti alle battute il nome di ogni personaggio, poi inseriscile nel fumetto giusto:

: Guarda bene a destra e a sinistra, quando attraversi la strada!... : No, l'autista dello scuolabus era un criminale! : Sua madre era apprensiva? :...Che a me, ieri, a momenti mi falciavano! : Sì, caro.

: E anche quando è verde, guarda ancora a destra e a sinistra, perché c'è sempre il matto che passa col rosso!...

Tal exercício foi feito em duplas pelos aprendizes. Enquanto eles o faziam, caminhamos pela classe apenas para observá-los e esclarecer eventuais dúvidas que eles tivessem. Demoraram quase quinze mintos para conclui-lo e, logo em seguida, fizemos, juntos, a correção da atividade.

Uma aluna disse: “Enrico è... come si dice 'neurótico'?”. Respondemos-lhe: "nevrotico". A estudante prosseguiu: "Allora lui è nevrotico"114". Enquanto fazíamos a

\footnotetext{
Cesira: Sim, querido!

Quadrinho 4 - Enrico: E passe só com o verde!

Cesira: Sim, querido!

Quadrinho 5 - Enrico: E mesmo quando estiver verde, olhe de novo para a direita e para a esquerda, porque há sempre o doido que passa com o vermelho!... Cesira: Sim, querido!

Quadrinho 6 - Enrico: ...Que, ontem, por instantes, quase me matavam! Cesira: Sim, querido!

Quadrinho 7 - Enrico: Sabe, senhora, desde a creche, fui obcecado pelos acidentes de trânsito! Marta: A mãe do senhor era muito preocupada?...

Quadrinho 8 - Enrico: Não, o motorista do ônibus escolar era um criminoso!

${ }^{114}$ Tradução: "Então ele é neurótico".
} 
correção do exercício, procuramos deixar claro, para os alunos, que o humor de tal história reside no fato inusitado de Enrico ser obcecado por acidentes de trânsito, não porque sua mãe era muito preocupada e apreensiva, mas sim, porque era um criminoso o motorista do ônibus escolar que ele pegava, quando criança; ou seja, o motorista era o causador de muitos acidentes, dos quais Enrico foi testemunha. Após esse esclarecimento, a mesma aluna exclamou: "Poverino!115”. E os outros estudantes começaram a rir.

A terceira história ${ }^{116}$ que trabalhamos com nossa turma foi a da página 168 do livro já citado:

${ }^{115}$ Tradução: "Coitadinho!”.

${ }^{116}$ Tradução da história:

Quadrinho 1 - Mosè: Vá procurar uma!

Quadrinho 2 - Glicerina: Eu não, emprestei-a!

Quadrinho 3 - Enrico: Vamos lá, Cesira, procure melhor!

Quadrinho 4 - Enrico: Parecia-me que você tivesse uma, outro dia!...

Alfredo: Sim, mas não funcionava!

Quadrinho 5 - Krug: Não, eu uso este!...

Glicerina: Desculpe, senhor! Obrigado mesmo assim!

Quadrinho 6 - Marta: Tem certeza?

Alberto: Já disse a você que não tenho.

Quadrinho 7 - Mosè: Possível que em toda a fazenda não se encontre uma caneta que escreve?! 

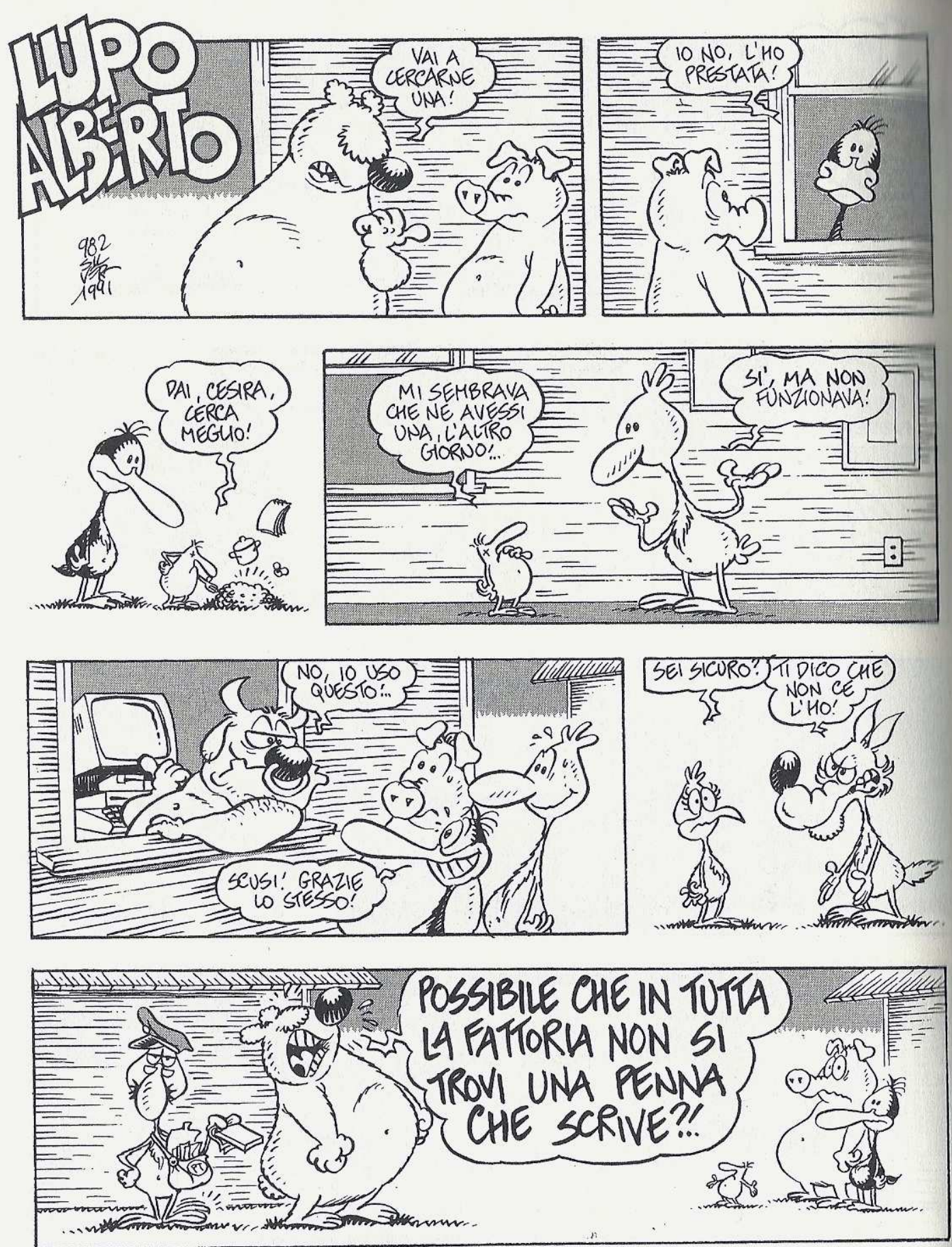

168

Figura 6 - A terceira e última história utilizada com nossos aprendizes

Antes de tirar cópias da história acima para distribuir aos alunos, retiramos, do último quadrinho, as palavras "penna" e "scrive", que são centrais para a compreensão do texto. Eliminados esses vocábulos, tiramos uma cópia do texto para cada aluno. Com base nessa história, elaboramos alguns exercícios, que mostramos a seguir: 


\section{Rispondi alle domande e discuti le tue risposte con un compagno:}

1. Qual è l'oggetto che tutti gli animali della fattoria cercano?

Leggete la storia e provate a scoprirlo. Dopo completate la battuta di Mosè con il nome dello strumento e con il verbo mancante:

\section{Perché Mosè ha bisogno di quell'oggetto?}

3. Adesso guardate il testo originale per vedere se avete indovinato la risposta alla domanda 1.

4. Cercate nelle battute le parole che si usano per sostituire il nome di questo strumento e copiatele sotto:

A história que escolhemos é muito interessante para trabalhar relações dêiticas com os alunos: no texto inteiro, os animais procuram um objeto, mas somente no último quadrinho, é revelado que objeto é esse. Portanto, os discentes devem observar atentamente as imagens e ler com cuidado as falas dos animais, pois elas trazem marcas linguísticas que permitem ao leitor descobrir de que objeto se trata; por exemplo: "una", presente no primeiro e no quarto quadrinhos, indica que o objeto é nomeado com uma palavra feminina; "l’ho prestata" (o pronome "la" e o particípio passado terminado em "a" reforçam a ideia de que o vocábulo é feminino); essas palavras têm uma relação catafórica com o substantivo que dá nome ao objeto procurado pelos animais; no último quadrinho, Mosè utiliza o artigo indefinido "una", o que confirma o gênero do vocábulo em questão.

As imagens poderiam, também, auxiliar os alunos a descobrir qual era o objeto: no quinto quadrinho, Krug aponta para um computador, o que poderia indicar que o objeto procurado tem a mesma funcionalidade desse instrumento tecnológico (no caso, a funcionalidade refere-se à escrita). No sétimo quadrinho, vê-se um carteiro segurando uma espécie de caderninho, o que também pode auxiliar os aprendizes na elaboração de inferências que os levem a entender a que objeto Mosè se refere. 
Demos aos estudantes alguns minutos para fazer a atividade: em duplas, os alunos leram o texto e, poucos minutos depois, já tinham descoberto qual era o objeto procurado. A resposta dos aprendizes quanto a isso foi unânime: "penna" (caneta), e para nós, foi muito interessante notar que eles disseram que o que os fez concluir que o objeto era esse foram justamente as imagens e as marcas linguísticas já mencionadas.

No tocante ao verbo que faltava no último quadrinho, contudo, as respostas das duplas foram duas: "funziona" (respostas de duas duplas) e "scrive" (resposta de quatro duplas). Quando lhes mostramos a história completa, alguns estudantes perguntaram-nos: “Perché 'scrive' e non 'funziona'? È sbagliato usare 'funziona'?117". Respondemos-lhes que os dois verbos poderiam ser usados naquele contexto, mas que o autor tinha preferido o verbo "scrivere", talvez pelo fato de ser o mais usado com o substantivo "penna".

Ao final dessas atividades, perguntamos aos discentes o que eles acharam delas, e todo o grupo afirmou ter gostado bastante do trabalho referente ao lobo Alberto, o que foi muito gratificante para nós. A aplicação de todas essas atividades durou, no total, três horas.

Em suma, foi esse o processo de didatização das histórias em quadrinhos italianas que escolhemos para trabalhar com nosso grupo do nível I do Italiano no Campus. Esperamos ter conseguido mostrar que esse processo:

- começa com a escolha do texto a ser trabalhado com os alunos;

- requer a definição dos objetivos a serem atingidos por eles a partir do material trabalhado;

- envolve a elaboração das atividades e/ou a escolha das técnicas didáticas que permitirão o alcance desses objetivos;

- abrange a aplicação das atividades elaboradas e/ou selecionadas pelo professor com base no texto autêntico escolhido;

- conclui-se com a avaliação de tais atividades pelo docente e pelos estudantes.

Ao usar o termo avaliação, referimo-nos à maneira como os alunos receberam os materiais autênticos que escolhemos e as atividades que propusemos, aos aspectos positivos desse trabalho e às dificuldades encontradas durante a realização deste. Essa avaliação compete, desse modo, tanto ao professor (que deve refletir constantemente sobre o trabalho desenvolvido junto aos aprendizes, procurando aperfeiçoá-lo) quanto aos estudantes (que poderão dizer, ao docente, se gostaram ou não do trabalho realizado e dar

${ }^{117}$ Tradução: "Por que 'escreve', e não 'funciona'? É errado usar 'funciona'?”. 
sugestões, ou fazer eventuais críticas e/ou elogios, para que o professor possa melhorar as atividades).

Todas essas etapas exigem do professor tempo, dedicação, estudo e reflexões constantes, o que corrobora o que alguns teóricos da área de didática das línguas estrangeiras dizem, ou seja, que trabalhar com materiais autênticos na sala de aula é uma tarefa bastante árdua e complexa. Apesar disso, esse trabalho é, a nosso ver, bastante enriquecedor tanto para o docente quanto para os discentes e, portanto, deve ser realizado sempre que possível. 


\section{CONSIDERAÇÕES FINAIS}

Nesta dissertação, procuramos mostrar que os materiais autênticos, se didatizados pelo professor de LE com base nos interesses e nas necessidades de aprendizagem dos discentes, podem ser valiosos instrumentos no processo de ensino-aprendizagem da língua-alvo, tornando-se fontes de insumo compreensível para os alunos e favorecendo a aprendizagem significativa dessa língua por parte deles.

No primeiro capítulo, discorremos acerca de algumas polêmicas referentes ao uso dos materiais didáticos na pedagogia de línguas, verificando que há controvérsias quanto ao emprego do representante clássico dessa categoria de material, ou seja, o livro didático. Alguns autores, entre os quais Mezzadri, defendem o seu uso, porque acreditam que o LD represente, para o aluno, a possibilidade de seguir um percurso didático planejado e organizado, o que lhe dá segurança e autonomia no estudo da língua-alvo. Outros, contudo, como Widdowson e Spinelli, argumentam que o LD não é capaz de abarcar a complexidade da língua-alvo e, em geral, não atende aos diversos interesses dos discentes.

Dentro de tal polêmica, tentamos esclarecer que, na sala de aula de LE, há espaço para os materiais didáticos e para os materiais autênticos, ou melhor, que não se deve usar exclusivamente um único tipo de material, embora seja preferível a utilização de materiais autênticos, pois estes constituem uma fonte de input genuíno para o aprendiz.

O conceito de input também foi abordado no capítulo 1 e, como vimos, o termo refere-se à língua-alvo oferecida ao estudante, isto é, a todos os textos orais ou escritos produzidos na LE e dos quais o aluno é circundado. Por sua vez, o termo input compreensível, que faz parte de uma das hipóteses da Teoria de Aquisição de Segunda Língua, de Krashen, diz respeito ao insumo que contém elementos que o aprendiz já conhece, bem como elementos que vão "um pouco além" do estágio de aquisição linguística em que ele se encontra.

Ao usar a expressão "um pouco além”, Krashen parece querer dizer que, para compreender textos na língua-alvo, usamos não apenas a nossa competência linguística, mas também o contexto, nosso conhecimento de mundo e informações extralinguísticas, ou seja, ele ressalta, de alguma forma, a importância, no processo de aquisição da LE, daquilo que o aprendiz já sabe. Isso vai ao encontro da Teoria da Aprendizagem Significativa, de Ausubel, a qual salienta a grande relevância dos conhecimentos prévios do estudante. 
Tanto Krashen quanto Ausubel são considerados cognitivistas e, embora o primeiro seja um estudioso da área de aquisição de L2, e o segundo seja um psicólogo da educação, os postulados teóricos de ambos apresentam um aspecto em comum: a importância atribuída aos conhecimentos prévios do aprendiz. Nesse sentido, a hipótese do input compreensível corrobora os postulados da teoria ausubeliana.

Mas, qual é a relação entre os materiais que usamos no processo de ensinoaprendizagem de LE e os postulados desses dois teóricos? Leffa afirma que o material entregue ao aluno deve ser, por um lado, adequado ao seu nível de conhecimento e, por outro, fornecer-lhe novos conhecimentos. Além disso, ele esclarece que aquilo que o estudante já sabe deve funcionar como um "andaime" para que ele alcance aquilo que ainda não sabe e deve aprender. Esse autor ressalta que uma condição necessária para que um material se torne realmente um instrumento de ensino-aprendizagem da língua-alvo é a capacidade de acionar o conhecimento prévio do aprendiz.

Das etapas do processo de didatização de materiais autênticos, fazem parte a seleção do texto autêntico e a preparação de atividades com base nele e, como vimos, é necessário e importante que, em tais etapas, os conhecimentos prévios dos discentes sejam levados em conta, como salientam Ausubel e Leffa.

Além disso, os textos autênticos dão aos alunos a oportunidade de ter acesso ao que Brown e Menasche denominam input genuíno, o qual, segundo Spinelli (2003), contribuirá para o desenvolvimento da estrutura cognitiva do aprendiz, para o desenvolvimento de suas habilidades intuitivas e analíticas e, também, para a aproximação deles à cultura do povo falante nativo da língua-alvo.

Tendo em vista que os textos autênticos contribuem para o desenvolvimento da estrutura cognitiva do aprendiz, podemos dizer que eles têm a potencialidade de favorecer a aprendizagem significativa da LE por parte dos estudantes: se adequadamente didatizados, esses materiais poderão ativar os conhecimentos prévios dos alunos e irão ao encontro de seus interesses.

Obviamente, os materiais didáticos, se utilizados de maneira a atender aos interesses e necessidades dos estudantes, também poderão favorecer a aprendizagem significativa da LE. Entretanto, é preferível o uso de textos autênticos, porque estes, além de ativar os conhecimentos prévios estritamente linguísticos dos alunos, também podem ativar seus subsunçores referentes à cultura, o que fará com que os aprendizes compreendam melhor sua própria cultura e se aproximem, de forma significativa, da cultura-alvo. 
No segundo capítulo, tentamos verificar em quais métodos e abordagens de ensino de línguas estrangeiras estavam presentes os materiais autênticos e de que forma se dava essa presença. Para tanto, fizemos uma breve descrição das características fundamentais dos principais métodos e abordagens de ensino de LE: método gramática e tradução, método da leitura, método direto, método audiolingual, Community Language Learning, Total Physical Response, sugestopédia, método silencioso e abordagem comunicativa.

No interior de cada descrição, tratamos da questão dos materiais empregados em cada um dos métodos/abordagens e foi-nos possível constatar que, apesar da predominância do uso dos materiais didáticos nos métodos/abordagens que acabamos de mencionar, os materiais autênticos estão, de alguma forma, presentes na maioria deles.

Quanto à presença do material autêntico nos métodos tradicionais de ensino de LE, verificamos que este é utilizado em todos os métodos sobre os quais discorremos. Com relação à presença dessa categoria de material nos métodos alternativos de ensino de línguas estrangeiras, pudemos notar que ela é escassa, rara, quase inexistente.

Por fim, no que concerne à utilização de materiais autênticos na abordagem comunicativa, vimos que esta traz como um de seus princípios fundamentais o emprego dessa categoria de material. Esse princípio visa combater a artificialidade de frases inventadas e de textos elaborados ad hoc, presentes tanto em métodos tradicionais quanto em métodos alternativos de ensino de línguas; tem, também, o objetivo de defender o ensino-aprendizagem da "língua em uso", razão pela qual a abordagem comunicativa privilegia o emprego de materiais autênticos mais facilmente utilizados em situações reais de comunicação do dia a dia.

Entretanto, ao privilegiar esse tipo de material autêntico, tal abordagem coloca em posição secundária outros tipos de materiais autênticos, como os textos literários e, de certo modo, estabelece, assim, uma hierarquia referente à importância dos usos desse tipo de material.

No terceiro capítulo, procuramos esclarecer um conceito fundamental em nosso trabalho: o de didatização. Como não encontramos, na literatura consultada, uma definição clara para o conceito em questão, tivemos de propor uma. Para nós, a didatização consiste em um complexo processo de exploração do texto autêntico por meio de técnicas didáticas que visam torná-lo acessível e compreensível aos alunos, fazendo com que este seja realmente um instrumento de ensino-aprendizagem da língua estrangeira. 
Podemos dizer, baseando-nos na Teoria de Aquisição de Segunda Língua, de Krashen, e na Teoria da Aprendizagem Significativa, de Ausubel, que didatizar materiais autênticos constitui uma maneira de oferecer aos alunos input compreensível, o que poderá resultar na aprendizagem significativa da LE por parte dos estudantes.

Procuramos mostrar, também, que o processo de didatização envolve a utilização de técnicas didáticas. Tentamos explicitar que mais importante do que determinar a qual método/abordagem remete uma determinada técnica, é ter clareza dos objetivos que pretendemos atingir junto aos nossos aprendizes em cada atividade proposta. Ou seja, não devemos escolher um tipo de atividade com vistas à execução de um método e de uma abordagem, mas sim, com o propósito de ir ao encontro dos interesses e necessidades de aprendizagem de nossos discentes.

Como a técnica diz respeito ao nível das atividades realizadas na sala de aula, conhecê-las é um fator indispensável para podermos realizar o processo de didatização de materiais autênticos, com o intuito de utilizar essa categoria de texto em nossas aulas de língua estrangeira.

É obvio que é impossível ter conhecimento e domínio de todas as técnicas didáticas existentes, mas ter um repertório amplo de tais técnicas pode nos auxiliar na realização do trabalho didático-pedagógico com textos autênticos. Assim, no capítulo 3, vimos algumas delas sob duas perspectivas: a do desenvolvimento de habilidades e competências e a de bases neurolinguísticas.

Concluída a parte do capítulo 3 na qual discorremos sobre o conceito de didatização e as técnicas didáticas, tratamos de uma teoria linguística que embasa nosso trabalho: a Linguística Textual, uma vertente da Linguística cujo desenvolvimento iniciou-se na década de 1960, na Europa e, em particular, na Alemanha.

A LT, ao longo de seu desenvolvimento, passou por várias fases e, atualmente, sua hipótese de trabalho consiste em considerar como objeto particular de investigação, não mais a palavra ou a frase, e sim, o texto, pois os textos são a forma específica de manifestação da linguagem.

Entretanto, Marcuschi (2008) alerta-nos para o fato de que não há apenas uma LT, e Koch (1997) ressalta que o objeto de estudo da LT varia conforme a fase de desenvolvimento dessa teoria linguística e conforme o autor. No trabalho que aqui se apresenta, optamos pela Linguística Textual de base sociocognitivista, pois esta vai ao encontro de duas teorias que também alicerçam este trabalho: a Teoria de Aquisição de 
Segunda Língua, de Krashen, e a Teoria da Aprendizagem Significativa, de Ausubel, ambas também de bases cognitivistas.

Após discorrermos brevemente sobre a LT de base sociocognitivista, tratamos de alguns de seus conceitos fundamentais: o de texto, discurso, gênero textual, tipo textual e suporte.

Depois de tratarmos desses conceitos da Linguística Textual, que são muito relevantes para o nosso trabalho, procuramos mostrar algumas relações entre estes e a didatização de materiais autênticos. Para tanto, partimos de um postulado de diversos teóricos, entre os quais Danesi (1998), Mezzadri (2003), Spinelli (2003), Begotti (s. d.), Bonvino (2008) e Marcuschi (2008). Eles postulam que o ensino de línguas deva ter o texto como base, pois a comunicação se dá por meio de textos, e não de palavras isoladas e frases soltas.

Tendo em vista todos os aspectos que procuramos mostrar no capítulo 3, podemos afirmar que didatizar textos autênticos é, realmente, como salienta Begotti (s. d.), uma tarefa bastante árdua e complexa, que exige do professor muito estudo, tempo e dedicação, pois o docente deve ter noções do que é um material autêntico, bem como dos conceitos de texto, discurso, gênero textual, tipo textual e suporte. Deve, além disso, conhecer pelo menos algumas técnicas didáticas e observar atentamente seus alunos, para poder selecionar textos que atendam às suas necessidades de aprendizagem e aos seus interesses e para poder elaborar atividades que possibilitem aos estudantes a aprendizagem significativa da língua-alvo.

A complexidade do processo de didatização de materiais autênticos, a nosso ver, reflete a complexidade de nossa própria profissão: como professores de línguas estrangeiras, devemos conhecer bem a LE que é nosso objeto de ensino e saber como torná-la, para nossos alunos, realmente um objeto de aprendizagem, isto é, precisamos saber dar-lhes condições para que se apropriem da língua-alvo. Isso significa que precisamos não só ter vastos conhecimentos linguísticos e culturais referentes ao idioma que é nosso objeto de ensino, como também possuir um grande repertório de conhecimentos concernentes à didática de línguas e saber colocá-los em prática na sala de aula.

Saber didatizar materiais autênticos é, portanto, um conhecimento fundamental, embora seja apenas um dos conhecimentos de que todos nós, professores de LE (e de LM), necessitamos para tentar garantir um ensino da língua-alvo adequado às necessidades de aprendizagem e aos interesses de nossos estudantes. 
No quarto capítulo, a análise das respostas dos aprendizes do Italiano no Campus ao nosso questionário parece ter evidenciado que, para a maioria deles, o livro didático é um material de grande importância no processo de ensino-aprendizagem do italiano LE, principalmente pelo fato de o manual constituir uma referência para eles.

No entanto, tais respostas também explicitaram que quase metade dos discentes nunca foi à Itália. Se tantos alunos ainda não puderam ir lá, o que nós, professores de italiano LE, podemos fazer para trazer um pouco da Itália para dentro da sala de aula? A resposta a essa questão está relacionada, a nosso ver, à utilização de materiais autênticos: tendo em vista que muitos de nossos estudantes nunca foram a tal país, fazer uso desses materiais, nas aulas de italiano LE, pode ser uma forma de reduzir a distância entre a sala de aula e a Itália, oferecendo aos aprendizes a possibilidade de ouvir e/ou ler textos que circulam no universo sociocultural dos italianos e de apropriar-se desses textos.

As declarações dos estudantes enfatizaram, de modo geral, uma vontade deles: a de que nós, professores de italiano LE, utilizemos, na sala de aula, (mais) atividades elaboradas com base em materiais autênticos.

De acordo com as respostas dos discentes, esses materiais são realmente um instrumento que pode aproximá-los da cultura italiana e inseri-los no país cuja língua os alunos estudam.

Assim, de acordo não só com alguns teóricos da área de didática das línguas estrangeiras, mas também com os próprios aprendizes, é realmente fundamental que, nas aulas de italiano LE, o professor utilize, sempre que possível, materiais autênticos, pois parecem ser esses os materiais que mais interessam aos discentes e com os quais eles se depararão fora da sala de aula.

Ainda no capítulo 4, vimos que todos os professores afirmaram usar, nas aulas do Italiano no Campus, outros materiais além do manual didático, o que indica que, para os docentes (assim como para os teóricos da área da pedagogia de línguas e para os aprendizes), é importante que as aulas contemplem uma variedade de materiais e atividades. Dentre os materiais complementares ao LD, a maior parte dos citados pelos docentes pertence à categoria dos materiais autênticos.

Levando em conta todos os dados mostrados e analisados nesta dissertação, poderíamos indagar: se tantos teóricos postulam a importância da utilização de materiais autênticos nas aulas de LE, se os aprendizes gostam tanto de atividades baseadas nessa categoria de material e se os professores de línguas estrangeiras também consideram esse 
uso relevante e necessário, por que continuamos a planejar nossos cursos, geralmente, com base em um livro didático?

A resposta a essa questão é muito complexa e envolve, sobretudo, aspectos institucionais e curriculares, como se pode notar ao lermos a seguinte declaração, na qual o professor afirma fazer uso do livro didático pelo fato de este ser um material obrigatório no curso: [Uso] O livro didático Linea diretta, porque é previsto pelo programa e todos os estudantes o compram, sem que eu possa dizer-lhes para não fazer isso" (docente de italiano há seis anos).

Ademais, tendo em vista que a maioria dos docentes ministra muitas aulas durante a semana e, portanto, possui um número grande de turmas, a utilização do LD pode facilitar o trabalho deles; é o que ilustra esta resposta: "Já o livro didático, uso porque é o material oficial do Italiano no Campus e porque, querendo ou não, o livro didático faz com que nós, professores, economizemos tempo no momento de preparação das aulas, já que, no geral, temos só que complementar o livro e não formular aula por aula" (docente de língua italiana há três anos e meio).

Outro aspecto que nos leva a usar esse material pode estar relacionado às necessidades dos discentes: como vimos, para muitos deles, o manual didático é um instrumento estruturado que lhes serve como referência e que lhes dá segurança.

Desse modo, uma resposta possível à questão que colocamos anteriormente é a seguinte: embora todos nós, professores de línguas estrangeiras, saibamos da necessidade e da importância de empregarmos materiais autênticos em nossas aulas, precisamos utilizar um LD por três motivos principais:

- as imposições institucionais - em geral, as instituições de ensino tornam obrigatório o uso de um determinado livro didático;

- o fato de esse material ser uma referência para muitos aprendizes;

- a praticidade desse material juntamente com a falta de tempo disponível para a preparação das aulas - como muitos docentes têm uma grande carga horária de trabalho, raramente têm tempo para pesquisar, selecionar e/ou preparar diferentes materiais e atividades; assim, é conveniente e prática a utilização de um LD, que já possui atividades prontas, as quais devem, geralmente, apenas ser complementadas pelos professores.

No quinto e último capítulo, procuramos descrever o processo de didatização de dois materiais autênticos que utilizamos com nossos alunos do nível I do Italiano no Campus. Os materiais escolhidos foram o folheto de supermercado e a história em 
quadrinhos, gêneros textuais do cotidiano, isto é, presentes na vida diária de todos nós. Ao longo do capítulo, explicamos os motivos que nos levaram a escolher esses gêneros, em detrimento de outros.

Com base em nossa experiência como professores de italiano, podemos dizer que o trabalho com textos autênticos apresenta aspectos muito positivos tanto para o docente quanto para os discentes.

Para o professor, esse trabalho representa a possibilidade de pesquisar sobre aspectos que atendam aos interesses, às expectativas e às necessidades dos aprendizes, elaborar atividades a partir das sugestões e solicitações dos alunos e exercitar a própria criatividade nessa elaboração. Portanto, ao desenvolver e aplicar atividades preparadas a partir de materiais autênticos, o professor torna-se, de certo modo, autor de suas próprias aulas, deixando de lado, sempre que possível, imposições colocadas por livros didáticos ou instituições.

Para os estudantes, tal trabalho representa a oportunidade de ter acesso ao input genuíno, que pode favorecer o processo de aprendizagem significativa da LE, envolvendo não apenas conhecimentos linguísticos, mas também conhecimentos culturais. Além disso, a pesquisa realizada com os aprendizes do IC mostrou que, para eles, esse trabalho torna as aulas mais motivantes e interessantes.

Entretanto, trabalhar com textos autênticos exige muito tempo e dedicação do professor e, como sabemos, geralmente, em nossa rotina profissional, o tempo é bastante escasso, pois temos uma carga horária de trabalho muito grande (nós, por exemplo, damos trinta horas de aulas por semana, e alguns de nossos colegas chegam a dar mais de quarenta), o que torna impraticável o trabalho constante com essa categoria de material.

Tendo em vista essa rotina, o livro didático parece ser realmente necessário, não só pelo fato de que ele serve como referência para os alunos, mas também, porque ele facilita o trabalho do professor, no sentido de que lhe oferece atividades que já estão "prontas". Tais atividades devem apenas ser escolhidas, adaptadas e/ou implementadas pelo docente, que, desse modo, não precisará criá-las. Ademais, em muitas instituições de ensino, o uso do LD é uma exigência, razão pela qual o professor deve utilizá-lo, independentemente de sua vontade.

Nossos aprendizes do nível I demonstraram grande interesse pelas atividades que elaboramos com base em materiais autênticos e manifestaram o desejo de ter, nas aulas, mais atividades criadas a partir desses materiais. Aliás, como vimos no capítulo 4, esse desejo também foi expressado pelos estudantes do Italiano no Campus de modo geral. 
Seria ótimo se nós, professores, tivéssemos mais tempo para preparar nossas aulas baseando-nos sempre nas solicitações de nossos alunos e não tendo de seguir imposições institucionais. Todavia, poucas vezes isso é possível.

Apesar disso, parece-nos que escolher textos autênticos a partir das necessidades de aprendizagem e interesses de nossos discentes e preparar atividades com base nesses materiais podem ser tentativas de: escapar de nossa rotina, que, muitas vezes, é massacrante; valer-se de nossa criatividade; e ir em busca de um trabalho com cuja realização as aulas tornem-se mais prazerosas e motivantes tanto para nós mesmos quanto para nossos aprendizes.

Assim, a partir de nossa experiência e da pesquisa realizada junto aos estudantes do IC, podemos dizer que, ainda que o trabalho com textos autênticos possa ser feito com pouca frequência, ele é enriquecedor para o professor e para os alunos e, portanto, vale a pena realizá-lo. 


\section{REFERÊNCIAS BIBLIOGRÁFICAS}

ALMEIDA FILHO, J. C. P. de. Dimensões comunicativas no ensino de línguas. Campinas: Pontes, 1993.

AUSUBEL, D. P; NOVAK, J. D; HANESIAN, H. Psicologia Educacional. Rio de Janeiro: Interamericana, 1980.

Educational Psycology: A cognitive view. Nova York: Holt, Rinehart and Winston Inc, 1968.

BACCIN, P. G. Giocando s'impara. São Paulo: Humanitas, 2007.

BAKHTIN, M. "Os gêneros do discurso". In: Estética da criação verbal. São Paulo: Martins Fontes, 1979.

BALBONI, P. E. Didattica dell'italiano a stranieri. Roma: Bonacci, 1994.

Curricolo di italiano per stranieri. Roma: Bonacci, 1995.

Dizionario di Glottodidattica. Perugia: Guerra Edizioni, 1999.

BEGOTTI, P. Didattizzazione di materiali autentici e analisi dei manuali di italiano per stranieri. Disponível em: http://venus.unive.it/filim/materiali/accesso_gratuito/ Filim_didattizzazione_analisi_teoria.pdf. Acesso em 11 de dezembro de 2011.

BONVINO, E. "I materiali didattici per l'insegnamento dell'italiano L2: criteri di selezione". Ultima revisione: 04 settembre 2008. Disponível em: http://www.italicon.it/. Acesso em 21 de agosto de 2011.

BORNETO, C. S. (org.). C'era una volta il metodo. Tendenze attuali nella didattica delle lingue straniere. Roma: Carocci, 1998. 
BREEN, M. "Authenticity in the language classroom". In: Applied Linguistics 6. Oxford: Oxford University Press, 1985.

BROWN, S; MENASCHE, L. "Defining authenticity". Disponível em: http://www.as.ysu.edu/ english/faculty/brown/personal/BrownMenasche. Acesso em 30 de novembro de 2011.

CANALE, M.; SWAIN, M. "Theoretical bases of communicative approaches to second language teaching and testing”. In: Applied Linguistics, 1980.

- "From communicative competence to language pedagogy". In: RICHARDS, J.; SCHMIDT, J. Language and communication. London: Longman, 1983.

CAON, F. Canzone pop e canzone d'autore per la didattica della lingua, della cultura italiana e per l'approccio allo studio della letteratura. Disponível em: http://venus.unive.it/filim/materiali/accesso_gratuito/Filim_caon_teoria.pdf. Acesso em 16 de junho de 2012.

CHIUCHIÙ, A; MINCIARELLI, F; SILVESTRINI, M. In italiano. Corso multimediale di lingua e civiltà a livello elementare e avanzato. Perugia: Guerra Edizioni, 2006.

CHOMSKY, N. Aspectos da teoria da sintaxe. Tradução de J. A. Meireles e E. P. Raposo. Coimbra: Armênio Amado Editora, 1975.

COMODI, A. Materiali autentici: selezione e uso nella didattica dell'italiano lingua straniera. Perugia: Guerra Edizioni, 1995.

CONFORTI, C; CUSIMANO, L. Linea diretta 1a. Perugia: Guerra Edizioni, 2005.

COSTE, D. "Hipothèses méthodologiques pour le niveau 2". In: Le français dans le monde. Paris: Larousse, 1970.

DANESI, M. Il cervello in aula. Neurolinguistica e didattica delle lingue. Perugia: Guerra Edizioni, 1998. 
DE MARCO, A. (org.). Manuale di Glottodidattica. Insegnare una lingua straniera. Roma: Carocci, 2000.

; WETTER, M. "L'apprendimento di una prima e di una seconda lingua”. In: DE MARCO, A. (org.). Manuale di Glottodidattica. Insegnare una lingua straniera. Roma: Carocci, 2000.

FÁVERO, L. L.; KOCH, I. G. V. Linguística Textual - Introdução. São Paulo: Cortez, 2008.

FRANZONI, P. H. Nos bastidores da comunicação autêntica. Uma reflexão em linguística aplicada. Campinas: Editora da UNICAMP, 1992.

GARDNER, R. Social psychology and second language learning: the role of attitudes and motivation. London: Arnold, 1985.

GIARDINI, F. "La suggestopedia e la psicopedia”. In: BORNETO, C. S. (Org.). C'era una volta il metodo. Tendenze attuali nella didattica delle lingue straniere. Roma: Carocci, 1998.

HYMES, H. D. “On communicative competence”. In: PRIDE, J. B; HOLMES, J. (eds.). Sociolinguistics. London: Penguin, 1972.

JOHNS, T. "The text and its message". In: COULTHARD, M. Advances in written text analysis. Londres: Routledge, 1994.

JÚDICE, N. (org.). Ensino da língua e da cultura do Brasil para estrangeiros: pesquisas e ações. Niterói: Intertexto, 2005.

KOCH, I. G. V. O texto e a construção dos sentidos. São Paulo: Contexto, 1997.

KRASHEN, S.; DULAY, H.; BURT, M. La seconda lingua. Bologna: Il Mulino, 1985.

Principles and Practice in Second Language Acquisition. Oxford: Pergamon Press Inc, 1982. 
KUMARAVADIVELU, B. Understanding Language Teaching: from Method to Postmethod. Mahwah, New Jersey: Lawrence Erlbaum Associates, 2006.

LARSEN-FREEMAN, D. Teaching techniques in English as a second language. Oxford: University Press, 1997.

LEFFA, V. J. "Como produzir materiais para o ensino de línguas". Disponível em: http://www.leffa.pro.br/textos/trabalhos/prod_mat.pdf. Acesso em 21 de fevereiro de 2012.

MARCUSCHI, L. A. Produção textual, análise de gêneros e compreensão. São Paulo: Parábola Editorial, 2008.

MARGUTTI, P. Comunicare in una lingua straniera. Dalla teoria alla pratica. Roma: Carocci, 2004.

MCLAUGHLIN, B. Theories of second language learning. London: Arnold, 1987.

MEZZADRI, M. I ferri del mestiere. Corso di (auto) formazione per l'insegnante di lingua. Perugia: Guerra Edizioni, 2003.

Il Quadro Comune Europeo a disposizione della classe. Un percorso verso l'eccellenza. Perugia: Guerra Edizioni, 2004.

MOREIRA, M. A. “O ensino de uma língua estrangeira”. In: MOREIRA, M. A; MASINI, E. F. S. Aprendizagem Significativa - a teoria de David Ausubel. São Paulo: Centauro, 2001.

NADDEO, C. M; TRAMA, G. Canta che ti passa - imparare l'italiano con le canzoni. Firenze: Alma Edizioni, 2000.

NUNAN, D. Research methods in language learning. Cambridge: Cambridge University Press, 1992.

PALLOTTI, G. La seconda lingua. Milano: Bompiani, 1998. 
PIVA, C. "Metodi in Glottodidattica". In: DE MARCO, A. (org.). Manuale di Glottodidattica. Insegnare una lingua straniera. Roma: Carocci, 2000.

PONTESILlI, A. "Il Silent Way". In: BORNETO, C. S. (Org.). C'era una volta il metodo. Tendenze attuali nella didattica delle lingue straniere. Roma: Carocci, 1998.

RICHARDS, J. C; RODGERS, T. S. Approaches and methods in language teaching. Cambridge: Cambridge University Press, 1986.

SCALZO, R. A. "L'approccio comunicativo. Oltre la competenza comunicativa". In: BORNETO, C. S. (Org.). C'era una volta il metodo. Tendenze attuali nella didattica delle lingue straniere. Roma: Carocci, 1998.

SILVA, M. A. C. M. B. É verdade ou faz-de-conta? Observando a sala de aula de língua estrangeira. 187 f. Tese (Doutorado em Linguística Aplicada) - Instituto de Estudos da Linguagem, Universidade Estadual de Campinas, 1999.

SILVESTRI, G. Lupo Alberto. T. V. B. Lupo! Trento: Oscar Mondadori, 2010.

SPINELLI B. “L'utilizzo dei materiali autentici nell'insegnamento dell'italiano come LS". In: DOLCI, R.; CELENTIN, P. (orgs.). In: La formazione di base del docente di italiano a stranieri. Roma: Bonacci, 2003.

VIEIRA, D. A. "Técnicas didáticas para a utilização de materiais autênticos na sala de aula de língua estrangeira". Serafino - Cadernos de Pós-Graduação do Programa de Língua e Literatura Italiana. FFLCH-USP. São Paulo, v. 4, p. 23-31, 2011.

. "O conceito de autenticidade e alguns critérios de seleção de textos autênticos para o ensino de italiano LE”. Serafino - Cadernos de Pós-Graduação do Programa de Língua e Literatura Italiana. FFLCH-USP. São Paulo, v. 3, p. 28-33, 2010.

Um breve panorama sobre a utilização (ou não) de materiais autênticos nos principais métodos e abordagens de ensino de línguas estrangeiras. In: ANAIS DO V ENCONTRO DE PÓS-GRADUANDOS DA FFLCH-USP. São Paulo: USP, 2010. 1 CD-ROM. 
A didatização de textos autênticos para o ensino de português para falantes de outras línguas. São Paulo: Pontifícia Universidade Católica de São Paulo, 2009. 82 p.

VISCIOLA, P. “Total Physical Response”. In: BORNETO, C. S. (Org.). C'era una volta il metodo. Tendenze attuali nella didattica delle lingue straniere. Roma: Carocci, 1998.

WIDDOWSON, H. G. O ensino de línguas para a comunicação. Tradução de José Carlos Paes de Almeida Filho. Campinas: Pontes, 2005.

WILKINS, D. Notional syllabuses. London: Oxford University Press, 1976. 
APÊNDICES 


\section{APÊNDICE A - QUESTIONÁRIO RESPONDIDO PELOS ALUNOS PESQUISA}

Nome (opcional):

Gênero: M ( ) F ( )

Idade:

Grau de escolaridade:

Área de formação:

Profissão:

Nível do Italiano no Campus que você cursa neste semestre:

1. Por que você optou por estudar italiano?

2. Você já foi à Itália? Em caso afirmativo, quantas vezes? E quanto tempo você ficou lá?

3. Há quanto tempo você estuda italiano?

4. O que você acha dos italianos e da Itália? (Você pode escrever palavras e/ou frases que vêm à sua mente quando você pensa neles). 
5. Você gosta das aulas de italiano? Por quê?

6. Do que você mais gosta nas aulas?

7. Do que você não gosta nas aulas?

8. O que você acha que poderia ser melhor nas aulas?

9. Além de ter contato com a língua italiana na sala de aula, você tem contato com ela em outros lugares? Em quais? De que forma ocorre esse contato? (Leituras, conversas, escuta de canções etc).

10. Quais atividades você prefere?

Numere de 1 a 5 as atividades de cada tipologia, de acordo com as suas preferências. Atenção! Nessa classificação, use o numeral 1 para indicar a atividade de que você mais gosta, e o 5 para aquela de que você menos gosta (ou não gosta). Utilize a letra $\mathrm{N}$ para indicar as atividades que não foram realizadas nas aulas que você já teve; se quiser, pode, também, acrescentar outras atividades que não foram mencionadas aqui, mas que você considera importantes. Pode, ainda, inserir algum comentário sobre as atividades. 
A) Atividades de compreensão oral (aquelas em que você deve compreender o que escuta):

( ) Ouvir textos do CD que acompanha o livro didático (em geral, diálogos) e preencher lacunas e/ou responder questões sobre eles.

( ) Ouvir textos de transmissões radiofônicas e/ou da internet, tais como entrevistas, publicidades, notícias, entre outros e preencher lacunas e/ou responder perguntas sobre eles.

( ) Ouvir canções e completar lacunas e/ou responder questões sobre elas.

( ) Assistir a um vídeo (filme, documentário, telejornal etc) e fazer anotações e/ou responder perguntas com base nele.

( ) Escrever palavras, frases etc ditadas pelo professor e/ou completar textos dos exercícios de ditado do livro didático.

Outras atividades:

Comentários:

B) Atividades de compreensão escrita (aquelas em que você deve compreender o que lê):

( ) Levantar hipóteses e fazer inferências sobre um texto com base em seu título.

( ) Ler textos do livro didático (como os diálogos iniciais de cada unidade) e responder questões sobre eles.

( ) Ler textos de jornais, revistas, publicidades, histórias em quadrinhos etc e responder perguntas a respeito deles.

( ) Ler textos literários (poemas, contos, autobiografias, romances etc) e responder questões acerca deles.

( ) Ler textos instrucionais (bulas, manuais, receitas etc) e responder perguntas referentes a eles.

Outras atividades:

Comentários:

C) Atividades de produção oral (aquelas em que você deve falar):

( ) Observar fotos, quadros, capas de livros, revistas etc e falar sobre eles.

( ) Descrever pessoas, objetos e lugares.

( ) Fazer discussões / debates com os colegas a respeito de temas trabalhados na sala de aula.

( ) Criar diálogos com base em modelos apresentados pelo livro didático e /ou pelo professor. 
( ) Dramatizar diálogos.

Outras atividades:

Comentários:

D) Atividades de produção escrita (aquelas em que você deve escrever):

( ) Escrever cartas, e-mails, cartões postais, entre outros.

( ) Responder perguntas baseadas em textos do livro didático.

( ) Responder questões referentes a textos literários (contos, poemas, romances etc)

( ) Escrever textos a partir de propostas apresentadas pelo professor (por exemplo, escrever sobre a própria infância, férias, acontecimentos importantes...).

( ) Fazer resumos, resenhas, paráfrases.

Outras atividades:

Comentários:

E) Atividades gramaticais (aquelas que focalizam as estruturas da língua):

( ) Transformar frases e/ou textos (do singular para o plural e vice-versa; do presente para o passado; do presente para o futuro; entre outras).

( ) Fazer exercícios de repetição (aqueles em que você tem de seguir o modelo).

( ) Fazer exercícios de substituição (por exemplo, reescrever as frases substituindo as palavras em negrito pelos pronomes diretos).

( ) Questões de múltipla escolha (por exemplo, assinalar a frase correta).

( ) Descobrir qual é a regra segundo a qual se deve utilizar uma determinada estrutura (exemplo: descobrir por que se diz "il gatto" / "i gatti").

Outras atividades:

Comentários:

F) Atividades lexicais (aquelas em que o foco é o vocabulário):

( ) Associar palavras às imagens.

( ) Associar palavras aos seus respectivos sinônimos.

( ) Associar palavras aos seus respectivos antônimos.

( ) Fazer traduções. 
( ) Eliminar a palavra que não pertence ao mesmo campo lexical das outras (exemplo: cane, gatto, albero, coniglio).

Outras atividades:

Comentários:

G) Atividades lúdicas:

( ) Jogos.

( ) Exercícios com piadas.

( ) Quiz.

( ) Mímicas.

( ) Charadas.

Outras atividades:

Comentários:

11. Há alguma atividade que você gostaria que o professor usasse (mais) em sala de aula? Qual? Por quê?

12. O que você acha do livro didático adotado em nossos cursos? (Você gosta do livro? Não gosta? Por quê?)

13. Quais os materiais de que você mais gosta?

Numere-os de acordo com as suas preferências. Nessa classificação, use o numeral 1 para indicar o material de que você mais gosta (exemplo: o material de que mais gosto é a canção, então a indicarei com o numeral 1; o segundo material de minha preferência é a história em quadrinhos, por isso, utilizarei o 2 para numerá-la; o terceiro é o filme, portanto o indicarei 
com o 3; e assim por diante). Utilize $\mathrm{N}$ para assinalar os materiais que não foram usados na sala de aula:

( ) o livro didático

( ) canções

( ) filmes

( ) telejornais

( ) publicidades

( ) ópera

( ) desenhos animados

( ) folhetos de supermercado

( ) bulas de medicamentos

( ) textos literários (poemas, contos, autobiografias, romances...)

( ) histórias em quadrinhos

( ) artigos de jornal

( ) entrevistas com pessoas famosas

( ) receitas

( ) documentários

( ) livros para estrangeiros (leitura graduada / facilitada)

( ) bilhetes de trem, de ônibus

( ) outros:

Justifique as suas três primeiras escolhas:

14. Há algum tipo de material que, na sua opinião, o professor deveria utilizar (mais) na aula de italiano? Qual? 
15. O que, na sua opinião, é importante para se aprender bem uma língua estrangeira?

16. Você já estudou outras línguas estrangeiras? Quais?

17. Você se considera um bom aprendiz de línguas estrangeiras? (Você pode levar em consideração sua aprendizagem do italiano e/ou de outras línguas estrangeiras, para responder essa questão). Por quê?

18. Na sua opinião, como deve ser uma boa aula de língua estrangeira?

19. E como é, para você, um bom professor de língua estrangeira? 


\section{APÊNDICE B - CARTA AOS ALUNOS DO ITALIANO NO CAMPUS}

São Paulo, agosto de 2011

\section{Caros alunos do Italiano no Campus}

Meu nome é Daniela Vieira e sou ex-monitora do Italiano no Campus. Desde 2009, desenvolvo, no Mestrado em Língua Italiana, na USP, uma pesquisa referente aos materiais no ensino do italiano como língua estrangeira.

Para coletar alguns dados para a pesquisa, preciso muito da sua colaboração. Vocês poderiam, por favor, responder o meu questionário?

Infelizmente, não pude vir, pessoalmente, a esta turma, para conversar com vocês a respeito da pesquisa e das perguntas. Por isso, pedi a colaboração de todos os professores (monitores) do Italiano no Campus para que as questões chegassem a todas as turmas.

O questionário é um pouco longo, mas não possui perguntas muito complicadas, como vocês podem ver. Alguns ex-alunos meus levaram cerca de quarenta minutos para respondê-lo. De preferência, respondam todas as questões, por favor! Não é necessário que vocês se identifiquem, porém, se quiserem fazê-lo, podem estar certos de que a sua identidade será preservada na pesquisa.

Caso queiram maiores esclarecimentos com relação às questões e à minha dissertação, podem entrar em contato comigo por meio dos seguintes e-mails: daniela.apvieira@usp.br, danielawel@zipmail.com.br ou daniela.apvieira@yahoo.com.br. Estou à disposição.

Conto com a sua valiosa colaboração!

Muito obrigada!

Atenciosamente,

Daniela Vieira 


\section{APÊNDICE C - CARTA AOS PROFESSORES DO IC}

\section{Caros colegas do Italiano no Campus}

Desculpem-me por "roubar" um pouco do tempo precioso das aulas de vocês! Eu sei bem que cada minuto das aulas vale muito, mas não havia outro jeito de coletar os dados.

Dentro desta pasta, coloquei o número de cópias do questionário correspondente à quantidade de alunos que vocês me passaram. Nas classes às quais não poderei ir pessoalmente, se vocês quiserem, podem mostrar a carta que escrevi aos alunos.

Já apliquei o questionário em duas turmas minhas. Em ambas, os estudantes levaram de trinta a cinquenta minutos para respondê-lo. Por isso, parece-me que uma hora-aula seja suficiente para cada turma preencher 0 questionário. Por favor, não apressem os alunos! Deixem que eles tenham esses quarenta e cinco minutos para preenchê-lo!

Eu gostaria de ter todos os questionários em mãos até o começo de setembro, por esse motivo, peço a vocês que os apliquem, se possível, até o dia 31/08/2011, nas turmas com as quais não poderei conversar pessoalmente. Nas demais classes, aplicarei o questionário nas datas que combinei com cada um de vocês.

Tenho de depositar a dissertação até o início de agosto de 2012, ou seja, tenho menos de um ano para concluir a pesquisa; assim, conto com a ajuda de vocês, para ter todos os questionários preenchidos pelos alunos o quanto antes.

Assim que eu tiver analisado todos os dados referentes à pesquisa $e$ tiver concluído a dissertação, disponibilizarei o material para vocês. Se eu também puder ajudá-los de alguma forma, podem contar comigo sempre.

Agradeço a todos pela colaboração!

Beijos,

Daniela 


\title{
APÊNDICE D - ATIVIDADES BASEADAS NA CANÇÃO “LAURA NON C'È"
}

\author{
Attività basate sulla canzone Laura non c'è, di SNek
}

Ascolta la canzone e completala con il verbo esserci al singolare e con le altre parole mancanti:

\section{Laura non c'è}

Nek

Laura non

Laura non è più cosa mia è andata via

E te che sei qua e mi chiedi

L'amo se niente più mi dà

Mi manca da spezzare il fiato

$\mathrm{Fa}$ e non lo sa

Che non mi è mai passata

Laura non

È stupido cercarla in te capisco che

lo sto da schifo credi e non lo vorrei

Stare con te e pensare a lei

Stasera voglio stare acceso

Andiamocene di là

A __ di pensare ho fuso

Se vuoi ci amiamo adesso, se vuoi

Però non è lo stesso tra di noi

Da solo non mi basto, stai con me

Solo è strano che al suo

Ci sei te, ci sei te

Laura dov'è? Mi manca sai

Magari c'è un accanto a lei

Giuro non ci ho pensato mai

Che succedesse proprio a noi

Lei si muove dentro a un altro

Su di un corpo che non è più il mio

$E$ io così non ce la faccio

Se vuoi ci amiamo adesso, se vuoi

Però non è lo stesso tra di noi

Da solo non mi basto, stai con me

Solo è strano che al suo posto

Ci sei te, ci sei te

Forse è così

Ma non so che cosa fare

Credo che sia

Per quanto io provi a scappare lei 
Non vorrei che tu fossi un'emergenza

Ma tra bene ed amore

Solo Laura è la mia

Se vuoi ci amiamo adesso oh no

Però non è lo stesso ora so ancora il suo tra me e te

Mi dispiace ma non posso, Laura

Se vuoi ci amiamo adesso, oh no

Mi casca il addosso e ora so ancora il suo riflesso tra me e te

Mi dispiace ma non posso

Laura , Laura

A) Scegli la risposta giusta:

1. Chi è Laura?

a) ( ) un'amica del cantante

b) ( ) la moglie del cantante

c) ( ) l'ex ragazza del cantante

2. Chi è la ragazza con cui parla il cantante?

a) ( ) Laura

b) ( ) una ragazza che è interessata a lui

c) ( ) un'amica del cantante

3. II cantante...

a) ( ) è ancora innamorato di Laura

b) ( ) è innamorato della ragazza con cui lui parla nella canzone

c) ( ) è innamorato di entrambe le ragazze

4. Il cantante proprone alla ragazza che è interessata a lui:

a) ( ) di stare con lui, anche se lui e Laura sono ancora insieme

b) ( ) di stare con lui, anche se lui pensa ancora a Laura

c) ( ) di stare con lui, perché possa dimenticare Laura 
B) Rispondi:

a) Se tu fossi in una situazione simile a quella della ragazza con cui il cantante parla, accetteresti la proposta che fa lui?
( ) sì
( ) no

Perché?

b) Hai già vissuto una situazione così? Conosci qualcuno che ne abbia già vissuta una?

5. Completa la tabella con i verbi che trovi nel testo della canzone:

\begin{tabular}{|l|l|l|l|}
\hline \multicolumn{1}{|c|}{ AMARE } & \multicolumn{1}{c|}{ CHIEDERE } & \multicolumn{1}{c|}{ CAPIRE } & \multicolumn{1}{c|}{ PARTIRE } \\
\hline IO amo & chiedo & & parto \\
\hline TU ami & & capisci & parti \\
\hline LUI ama & chiede & capisce & parte \\
\hline LEI ama & chiede & capisce & parte \\
\hline NOI & chiediamo & capiamo & partiamo \\
\hline VOI amate & chiedete & capite & partite \\
\hline LORO amano & chiedono & capiscono & partono \\
\hline
\end{tabular}

(Questo è lo schema dei verbi regolari all'indicativo presente)

6. Ti piace la canzone? Perché? 
APÊNDICE E - TERMO DE AUTORIZAÇÃO

\section{UNIVERSIDADE DE SÃO PAULO \\ FACULDADE DE FILOSOFIA, LETRAS E CIÊNCIAS HUMANAS PRÓ-REITORIA DE CULTURA E EXTENSÃO UNIVERSITÁRIA}

\section{AUTORIZAÇÃO - ALUNO - ITALIANO NO CAMPUS}

Eu, portador(a) do

documento de identidade ํo aluno(a) regularmente matriculado(a) no nível I do curso "Italiano no Campus", ministrado por Daniela Aparecida Vieira, na Faculdade de Filosofia, Letras e Ciências Humanas da Universidade de São Paulo, às segundas e quartas-feiras, das $17 \mathrm{~h} 30$ às $19 \mathrm{~h}$, no primeiro semestre de 2010, autorizo a gravação em áudio das aulas de língua italiana das quais participo como discente.

Declaro estar ciente de que a gravação das aulas será usada como material de análise em uma pesquisa situada no âmbito do ensino-aprendizagem do italiano como língua estrangeira e desenvolvida, sob orientação da professora Dra. Paola Giustina Baccin, por Daniela Aparecida Vieira, portadora do documento de identidade ํo 30.922.812-8, no USP 3498401, aluna do curso de Mestrado em Língua, Literatura e Cultura Italianas desta universidade. Assim sendo, autorizo a utilização da gravação de minha voz exclusivamente para as finalidades da referida pesquisa.

São Paulo, de de 2010.

\section{Ass. do(a) aluno(a)}




\section{APÊNDICE F - TERMO DE COMPROMISSO \\ UNIVERSIDADE DE SÃO PAULO \\ FACULDADE DE FILOSOFIA, LETRAS E CIÊNCIAS HUMANAS \\ PRÓ-REITORIA DE CULTURA E EXTENSÃO UNIVERSITÁRIA}

\section{TERMO DE COMPROMISSO}

Eu, Daniela Aparecida Vieira, portadora do documento de identidade 30.922.812-8, aluna regularmente matriculada no curso de Mestrado em Língua, Literatura e Cultura Italianas da Universidade de São Paulo, comprometo-me a utilizar a gravação em áudio das aulas ministradas por mim no nível I do Italiano no Campus, no $1^{\circ}$ semestre de 2010 , exclusivamente para as finalidades da pesquisa que estou desenvolvendo no referido curso de pós-graduação: investigação sobre o uso dos materiais autênticos nas aulas de italiano língua estrangeira.

Comprometo-me a preservar a identidade dos alunos participantes das aulas gravadas, citando-os na pesquisa apenas com nomes fictícios, ou identificando-os por números. Comprometo-me, ademais, a mostrar a esses alunos os resultados da análise que será exposta na pesquisa já mencionada, caso seja de interesse dos discentes.

São Paulo, 29 de março de 2010.

Ass. da aluna-professora-pesquisadora 


\section{APÊNDICE G - TRADUÇÃO DAS PERGUNTAS DO JOGO “LUPO ALBERTO"}

\begin{tabular}{|c|c|c|}
\hline $\begin{array}{l}\text { Como se chama o autor de } \\
\text { Lupo Alberto? } \\
\text { a) Sergio Endrigo } \\
\text { b) Guido Silvestri } \\
\text { c) Eugenio Montale }\end{array}$ & $\begin{array}{l}\text { Lupo Alberto é um } \\
\text { personagem... } \\
\text { a) tranquilo } \\
\text { b) nervoso } \\
\text { c) chato }\end{array}$ & $\begin{array}{l}\text { Como se chama a } \\
\text { namorada de Alberto? } \\
\text { a) Alice } \\
\text { b) Cesira } \\
\text { c) Marta }\end{array}$ \\
\hline $\begin{array}{l}\text { Quem é a melhor amiga da } \\
\text { Marta? } \\
\text { a) Alice } \\
\text { b) Cesira } \\
\text { c) Silvietta }\end{array}$ & $\begin{array}{l}\text { Onde vivem os personagens? } \\
\text { a) em uma floresta } \\
\text { b) em uma fazenda } \\
\text { c) em um bosque }\end{array}$ & $\begin{array}{l}\text { Quem é Alcide? } \\
\text { a) o marido de Cesira } \\
\text { b) o intelectual } \\
\text { do grupo } \\
\text { c) o inimigo de Alberto }\end{array}$ \\
\hline $\begin{array}{l}\text { Quem é o personagem que } \\
\text { entende de física e de } \\
\text { meteorologia? } \\
\text { a) Enrico, a toupeira } \\
\text { b) Lodovico, o cavalo } \\
\text { c) Alfredo, o peru }\end{array}$ & $\begin{array}{l}\text { Cesira é a esposa de... } \\
\text { a) Alberto } \\
\text { b) Mosè } \\
\text { c) Enrico }\end{array}$ & $\begin{array}{l}\text { Cesira sabe... } \\
\text { a) cozinhar bem } \\
\text { b) cantar bem } \\
\text { c) escrever bem }\end{array}$ \\
\hline $\begin{array}{l}\text { Qual é o animal mais otimista da } \\
\text { fazenda? } \\
\text { a) Krug, o touro } \\
\text { b) Joseph, o pato } \\
\text { c) Marta, a galinha }\end{array}$ & $\begin{array}{l}\text { Quem é o companheiro } \\
\text { inseparável de Glicerina? } \\
\text { a) Lodovico, o cavalo } \\
\text { b) Marta, a galinha } \\
\text { c) Alcide, o porco }\end{array}$ & $\begin{array}{l}\text { Quem são os dois personagens } \\
\text { irascíveis da fazenda? } \\
\text { a) Krug e Mosè } \\
\text { b) Glicerina e Alcide } \\
\text { c) Lodovico e Alberto }\end{array}$ \\
\hline $\begin{array}{l}\text { Qual é o grande desejo de Marta? } \\
\text { a) ter uma casa } \\
\text { b) casar-se } \\
\text { c) tornar-se rica }\end{array}$ & $\begin{array}{l}\text { Quem impede o amor entre } \\
\text { Alberto e Marta? } \\
\text { a) Odoardo } \\
\text { b) Mosè } \\
\text { c) Alcide }\end{array}$ & $\begin{array}{l}\text { Odoardo, o primo da Marta, é } \\
\text { muito: } \\
\text { a) antipático } \\
\text { b) bonito } \\
\text { c) simpático }\end{array}$ \\
\hline $\begin{array}{l}\text { O lobo Alberto é destinado ao } \\
\text { desentendimento } \\
\text { que som Mosè. O } \\
\text { sublinhada? } \\
\text { a) conflito } \\
\text { b) problema } \\
\text { c) amizade }\end{array}$ & $\begin{array}{l}\text { Cesira é muito ajuizada, ou } \\
\text { seja, é muito... } \\
\text { a) triste } \\
\text { b) alegre } \\
\text { c) prudente }\end{array}$ & $\begin{array}{l}\text { Enrico é um pouco malandro, } \\
\text { então é um pouco... } \\
\text { a) simpático } \\
\text { b) prudente } \\
\text { c) preguiçoso }\end{array}$ \\
\hline $\begin{array}{l}\text { Glicerina é o animal mais bobo } \\
\text { da fazenda, então é... } \\
\text { a) imbecil } \\
\text { b) inteligente } \\
\text { c) sincero }\end{array}$ & $\begin{array}{l}\text { Krug é um personagem } \\
\text { violento, isso quer dizer que ele } \\
\text { gosta de usar as "mãos" para: } \\
\text { a) fazer cócegas } \\
\text { b) bater } \\
\text { c) acariciar }\end{array}$ & $\begin{array}{l}\text { Marta é uma galinha vivaz, ou } \\
\text { seja, é... } \\
\text { a) antipática } \\
\text { b) doce } \\
\text { c) dinâmica }\end{array}$ \\
\hline $\begin{array}{l}\text { Mosè é um protetor da ordem } \\
\text { constituída. O que significa a } \\
\text { palavra sublinhada? } \\
\text { a) defensor } \\
\text { b) atacante } \\
\text { c) inimigo }\end{array}$ & $\begin{array}{l}\text { O lobo Alberto vive... } \\
\text { a) com os amigos } \\
\text { b) com a Marta } \\
\text { c) sozinho }\end{array}$ & 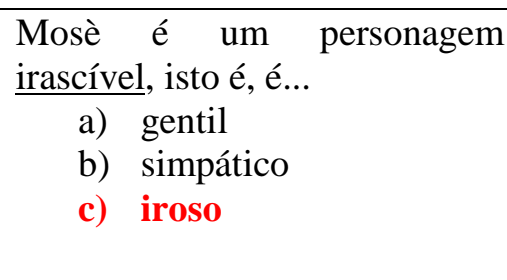 \\
\hline
\end{tabular}


ANEXOS 


\section{ANEXO A - ATIVIDADES BASEADAS NA CANÇÃO “CI VUOLE UN FIORE”, RETIRADAS DO LIVRO CANTA CHE TI PASSA}

\section{CANTA CHE TI DASSA}

Preascolto. Cosa ci vuole per fare un tavolo? Guarda i disegni e completa la sequenza secondo un ordine logico (il tavolo, il seme e il fiore sono già inseriti).
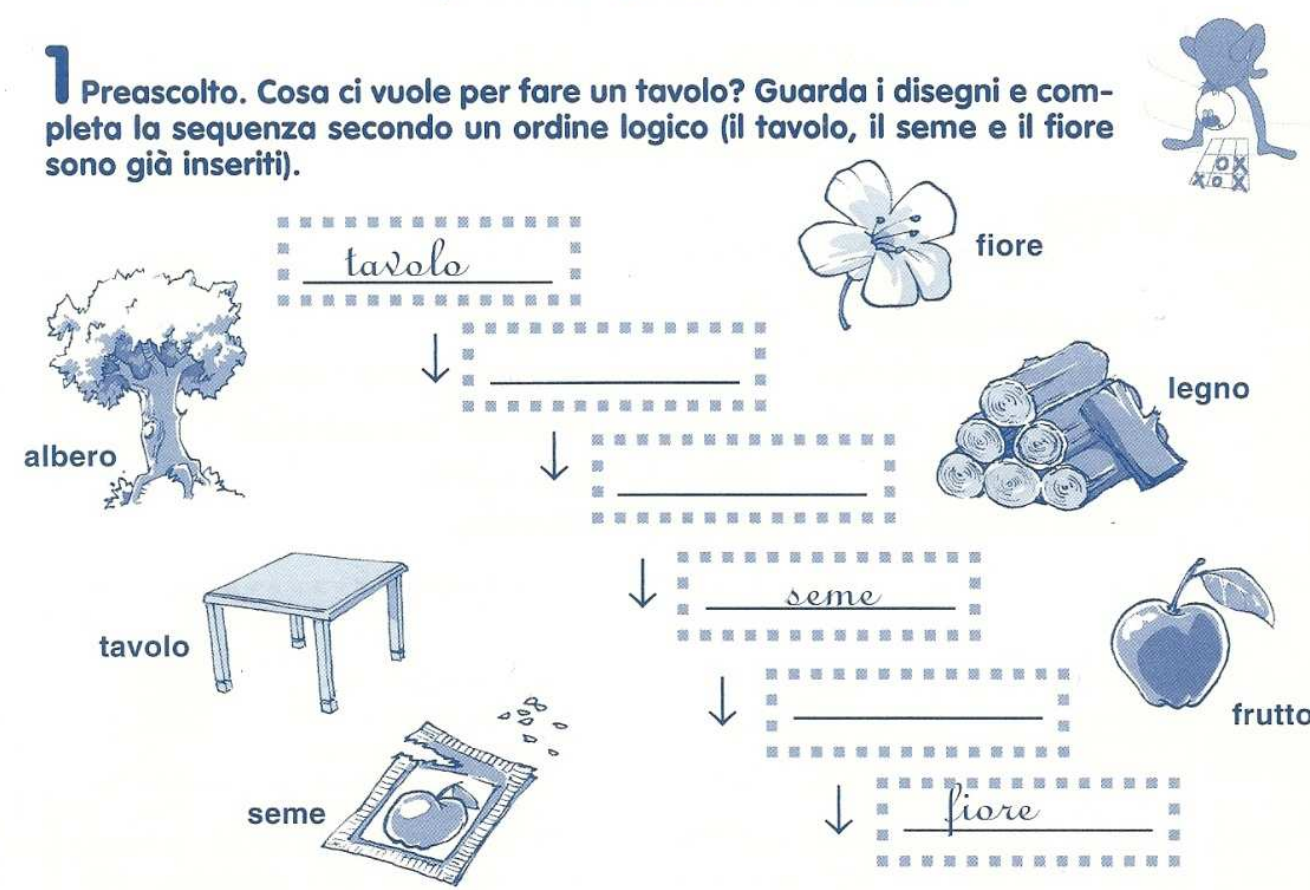

Ascolta la prima strofa della canzone (non di più) e verifica l’ordine della sequenza.
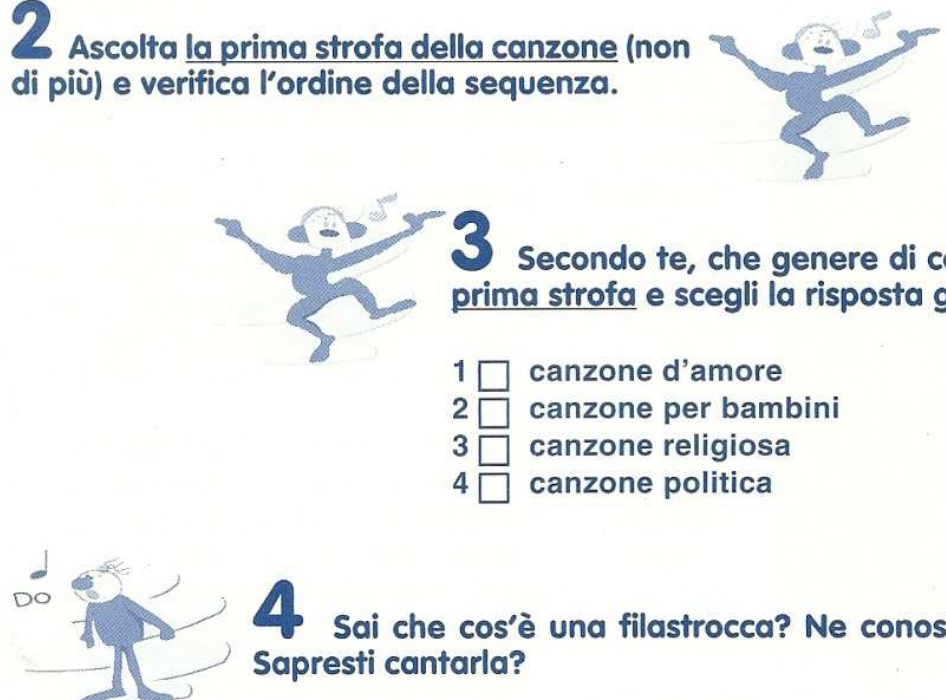

4 Sai che cos'è una filastrocca? Ne conosci una del tuo Paese? Sapresti cantarla?

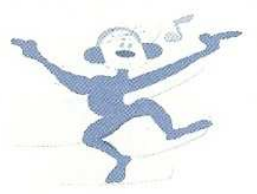

5 s Secondo la canzone, cosa ci vuole per di. 


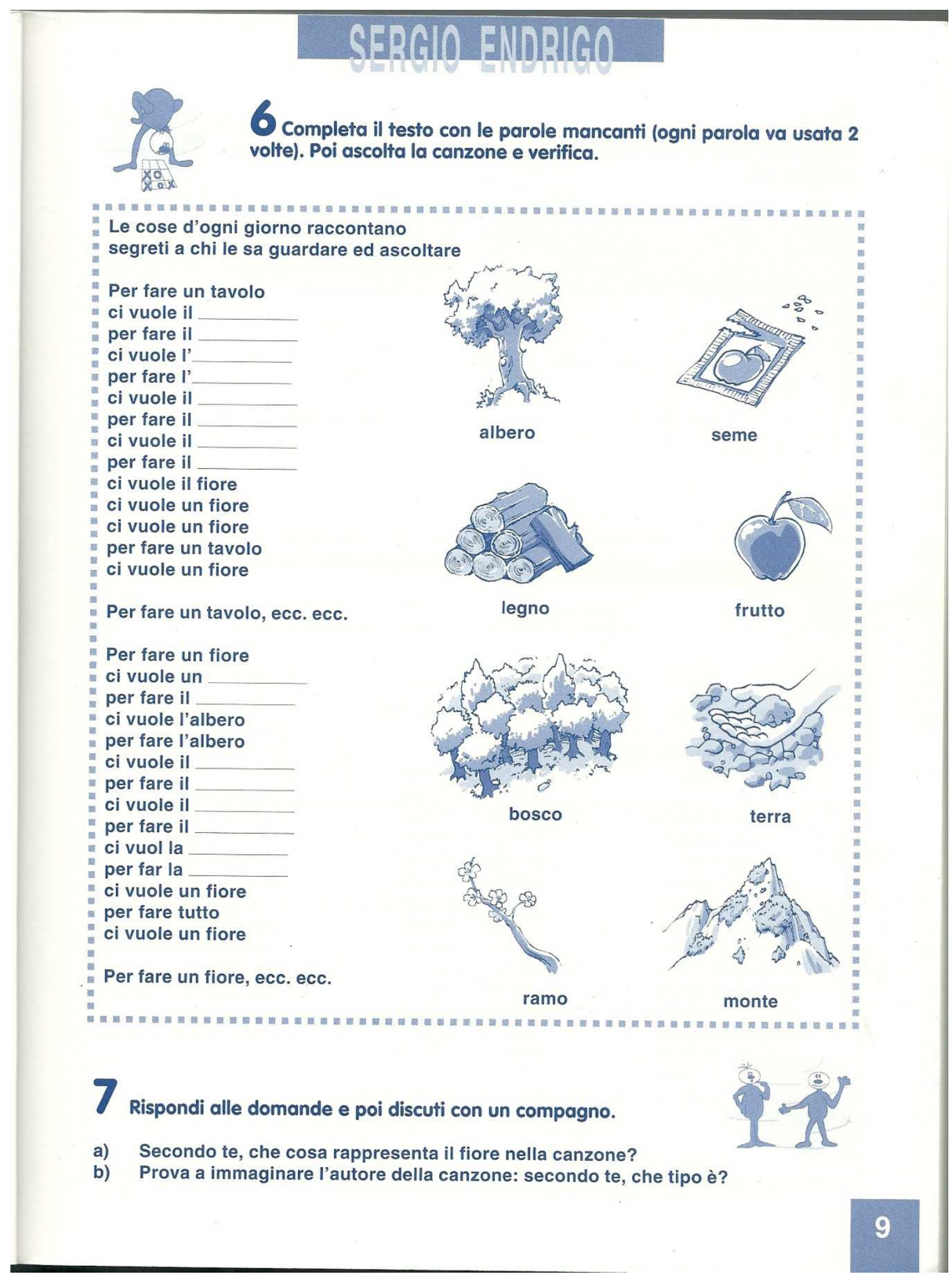


Questo è lo schema dell'articolo determinativo. Completa le colonne del singolare con gli articoli del testo della canzone.

L'articolo determinativo

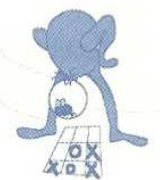

\begin{tabular}{|l|l|l|l|}
\hline \multicolumn{2}{|c|}{ maschile } & \multicolumn{2}{c|}{ femminile } \\
\hline \multicolumn{1}{|c|}{ singolare } & \multicolumn{1}{|c|}{ plurale } & \multicolumn{1}{c|}{ singolare } & \multicolumn{1}{c|}{ plurale } \\
$\ldots . .$. frutto & i frutti & ..... cosa & le cose \\
$\ldots . .$. albero & gli alberi & l'amica & le amiche \\
lo studente & gli studenti & & \\
\end{tabular}

10 cosa ci vuole per fare gli spaghetti al pomodoro? Completa la ricetta con gli articoli.

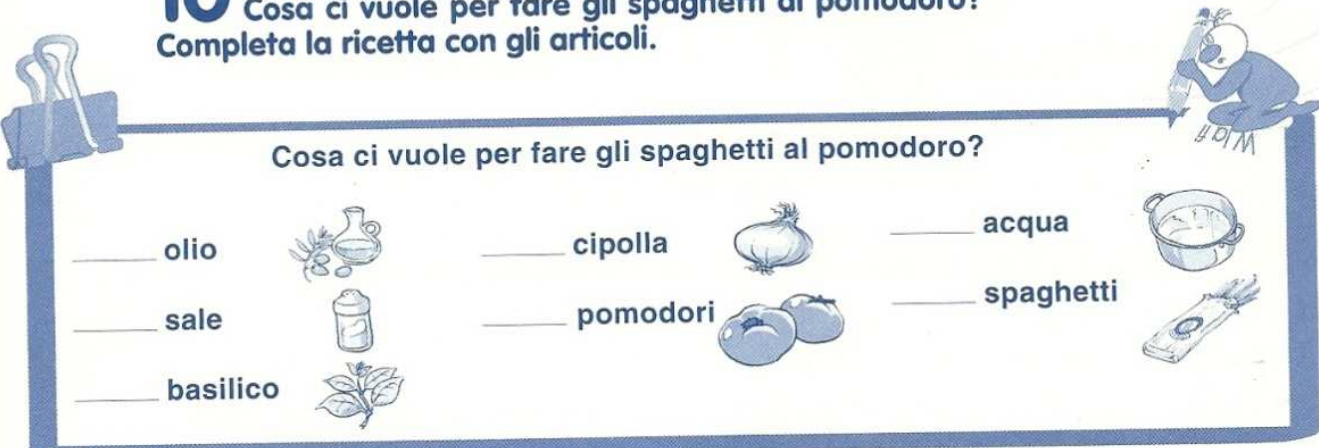

10 Ora scrivi tu i nomi degli ingredienti (con gli articoli) di una ricetta del tuo Paese. Se non conosci le parole italiane, usa il dizionario o chiedi all'insegnante.

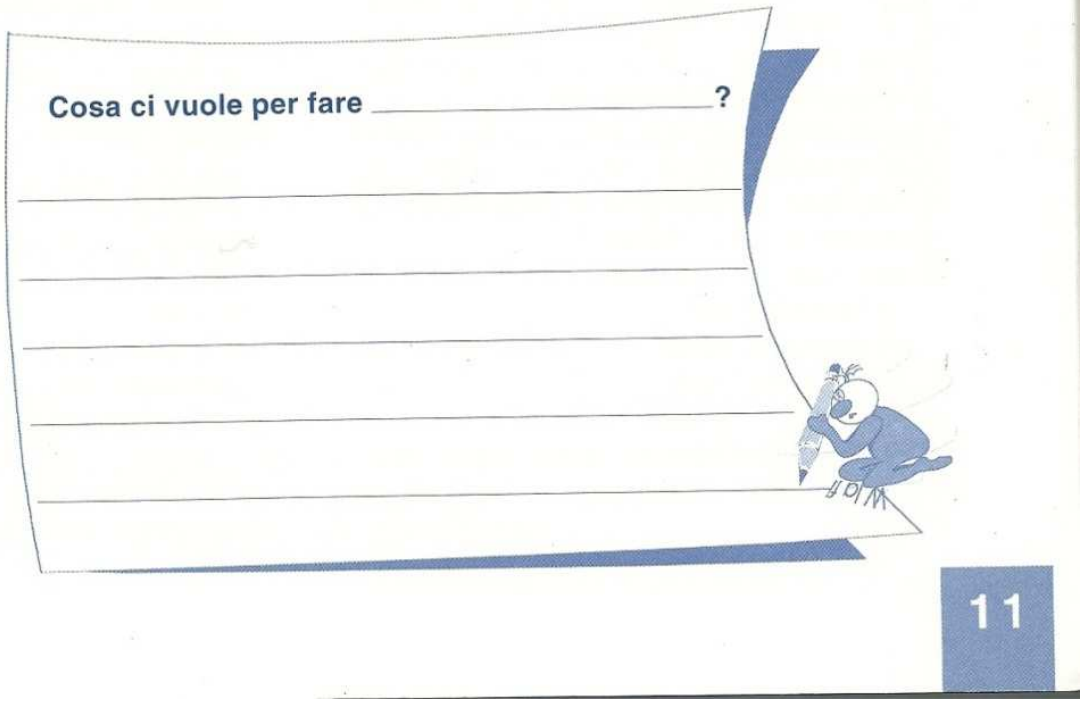




\section{ANEXO B - PÁGINA 20 DO LIVRO LINEA DIRETTA 1 A}

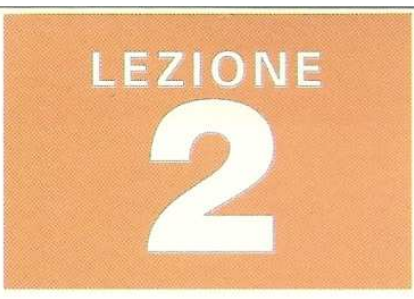

Che cosa prendi?

(1)

PER INIZIARE

\begin{tabular}{|c|c|c|c|}
\hline LISTI & P & $\begin{array}{c}\mathrm{R} \\
\mathrm{PRE}\end{array}$ & \\
\hline $\begin{array}{l}\text { SAFFET TERI } \\
\text { AFFE'ESPRESSO }\end{array}$ & & VERMOUTH & \\
\hline " CORRETTO & 1,34 & VINO NAZ AL BIC • & $\sum_{1,03}$ \\
\hline$\$$ DECAF. & 0,83 & "Est. & $\pi$ \\
\hline D LATTE & $>0,98$ & "DESSERT & $\| 2,58$ \\
\hline LATTE & $\triangleright 0,77$ & PORTO & $\$ 2,58$ \\
\hline CAPPUCCINO & $\sim 0,93$ & $81817 \mathrm{E}$ & \\
\hline IOCCOLATO & $\sim 1,29$ & BIRRA GRANDE & $>3,10$ \\
\hline HE & 0,83 & D PICCOLA, & $\$ 1129$ \\
\hline CAMOMILLA & $0,0,83$ & D ESTERA & 12,84 \\
\hline $\begin{array}{l}\text { PUNCH } \\
A P E R I T H V !\end{array}$ & - 1,81 & BIBITE LATTINA & $\begin{array}{l}D 1,81 \\
>1129\end{array}$ \\
\hline APERITIVI & 04,13 & - BOTtIGLIA & $>1,29$ \\
\hline - DI MARCA & 10,13 & SPREMUTE & 1,81 \\
\hline APEROL & 12,58 & SCIROPPI & 1,55 \\
\hline ANALCOLICH & $\sim 1,55$ & S PUMA & 10,62 \\
\hline BIANCO SARTI & $, 2,58$ & SUCCO DIFRU & A) 1155 \\
\hline AMARI & $\nabla 1,55$ & CEDRATA & $>1129$ \\
\hline $\begin{array}{c}\text { DI MARCA } \\
\text { LOUORI }\end{array}$ & $\$ 2,58$ & $\begin{array}{c}\text { GAssosA } \\
\text { SNAGK }\end{array}$ & $>1,29$ \\
\hline LIQUORI NAZ. & $\nabla 1,55$ & PASTE & $\$ 0,77$ \\
\hline BRANDY & $\nabla 1,55$ & PANINI & $\nabla 1,45$ \\
\hline RISERVA & $\$ 1,55$ & PIZZA & $\nabla 1,55$ \\
\hline APPA & $\nabla 1,55$ & TARTINE & $\nabla 1,55$ \\
\hline LIQUORI ES & 1,155 & TOAST & $, 1,45$ \\
\hline COGNAC & $, 1,55$ & FOCACCE & 12,58 \\
\hline WHISKY & 1,55 & ER 10 CHES & 00,62 \\
\hline
\end{tabular}


ANEXO C - FOLHETO DO SUPERMERCADO CARREFOUR ITALIANO

Carrefour

II mio ipermercato

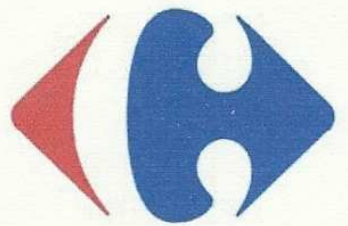

IA GONVENIENZA SIRMO KOI

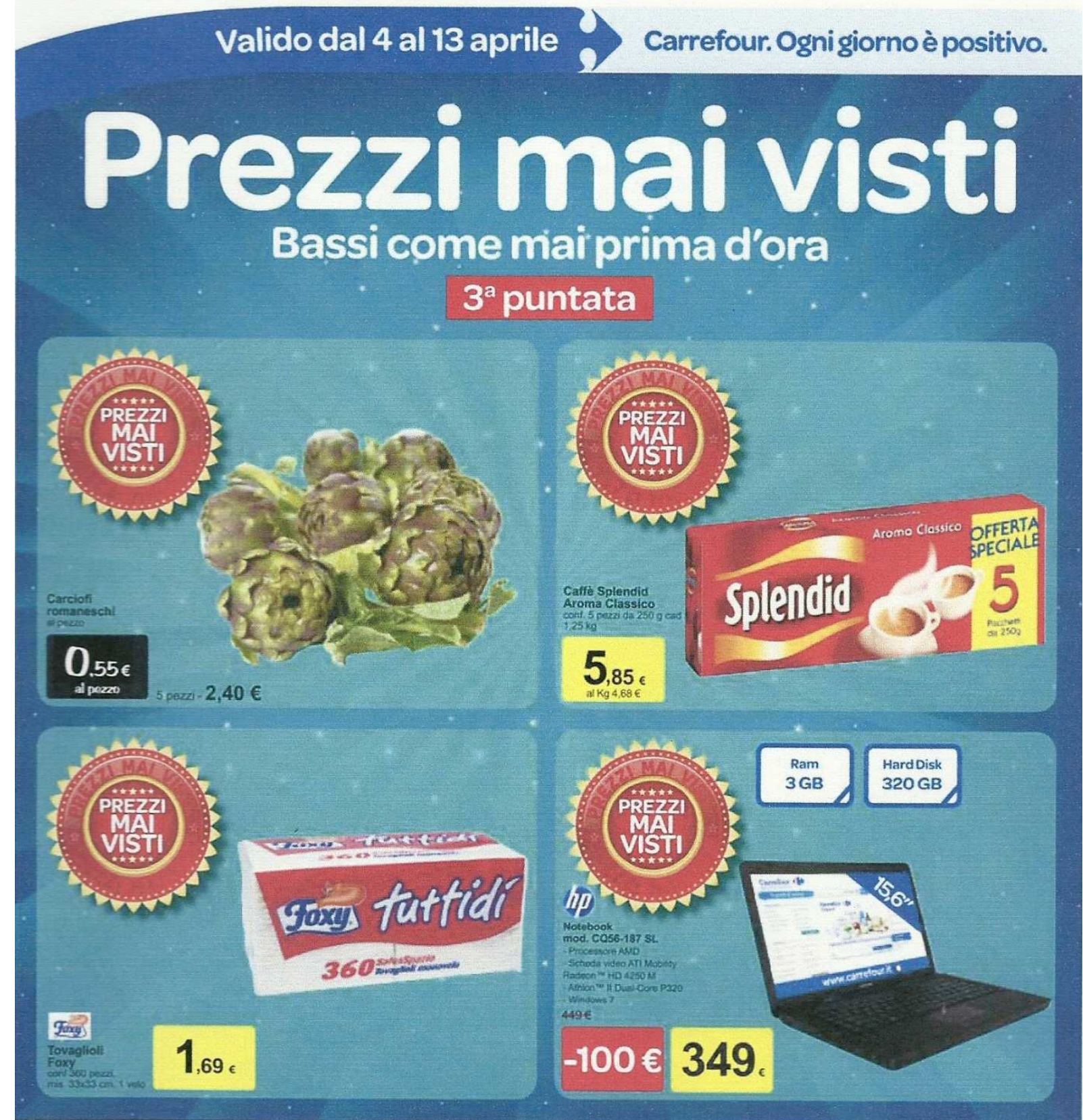




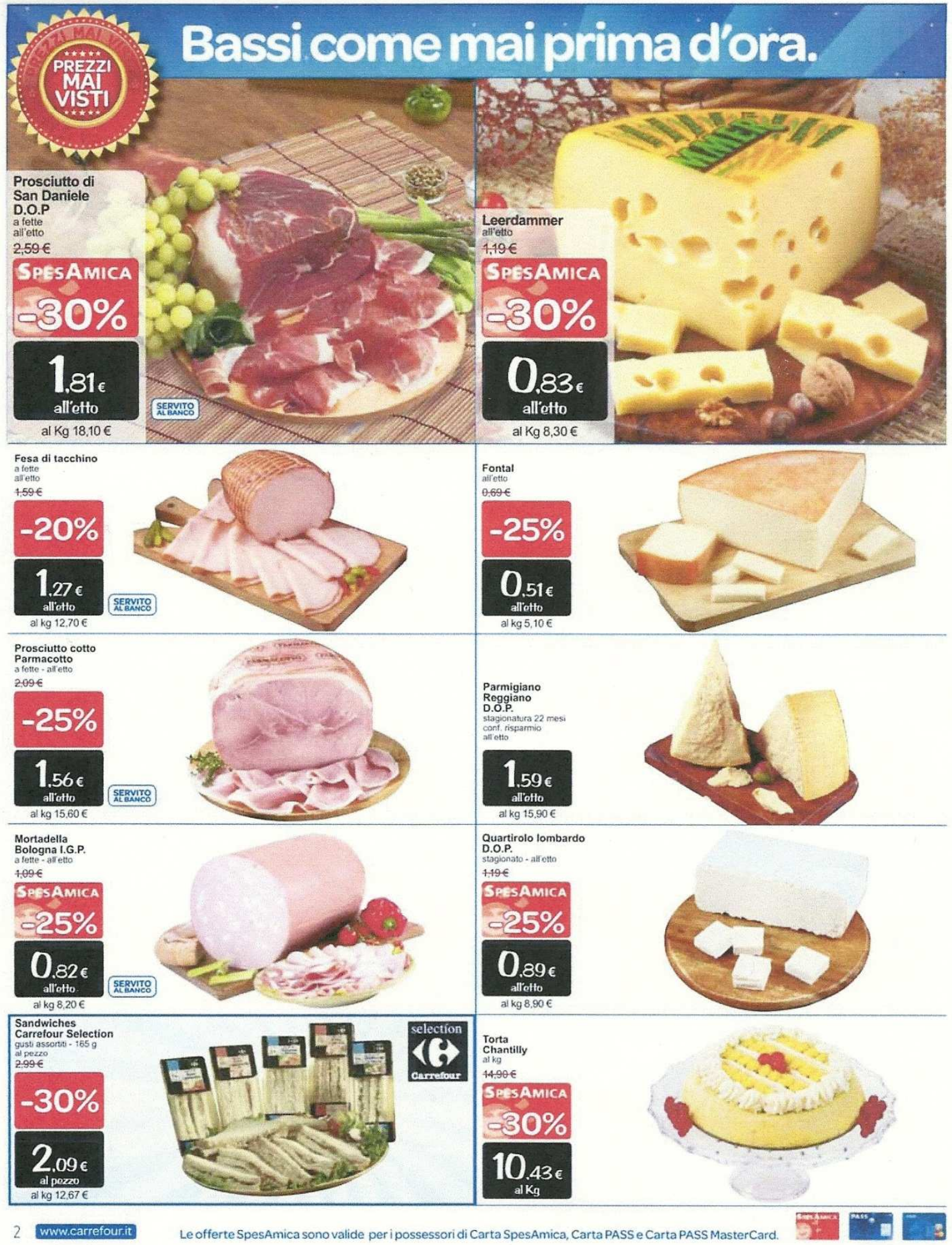




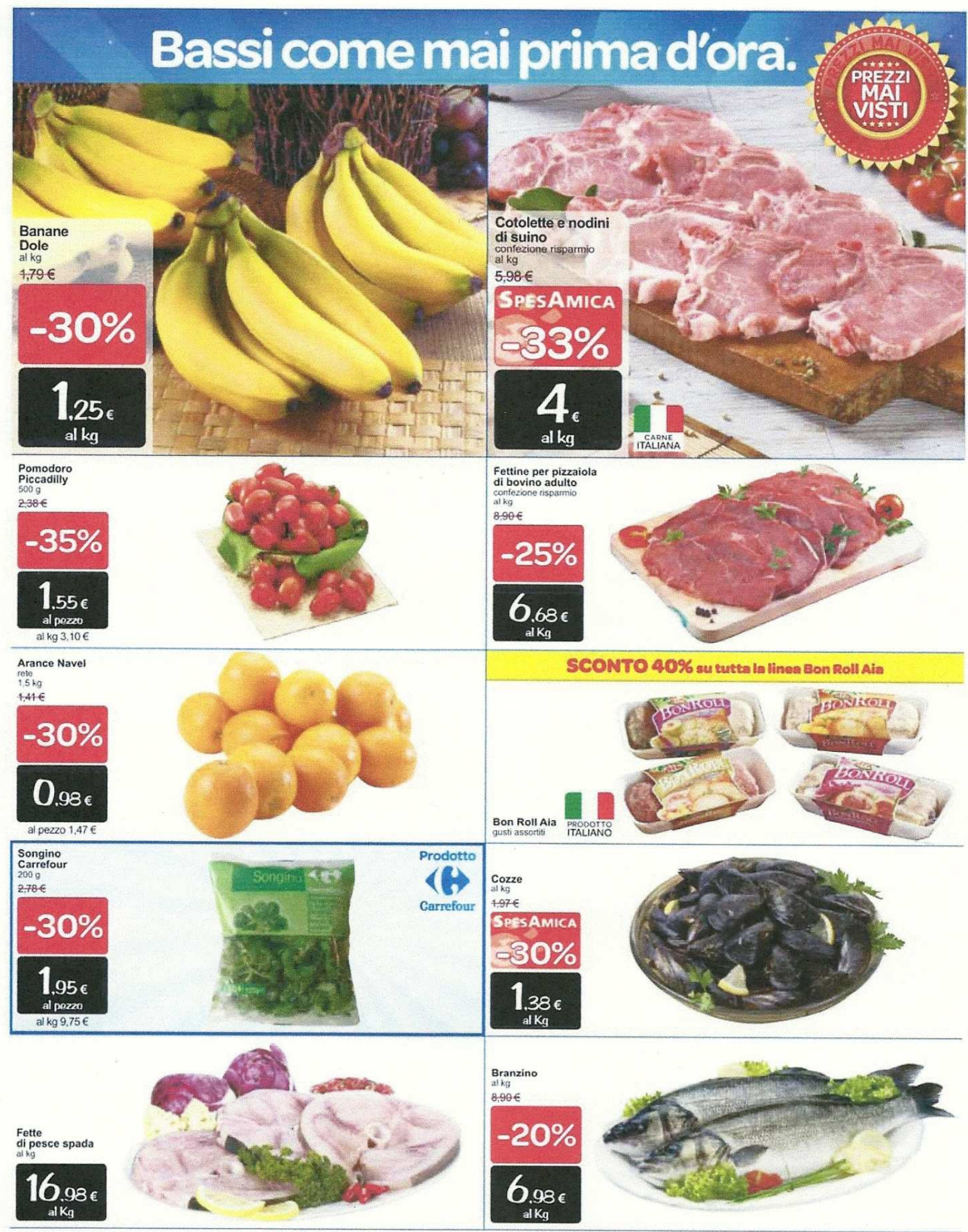




\section{Bassi come mai prima d'ora.}

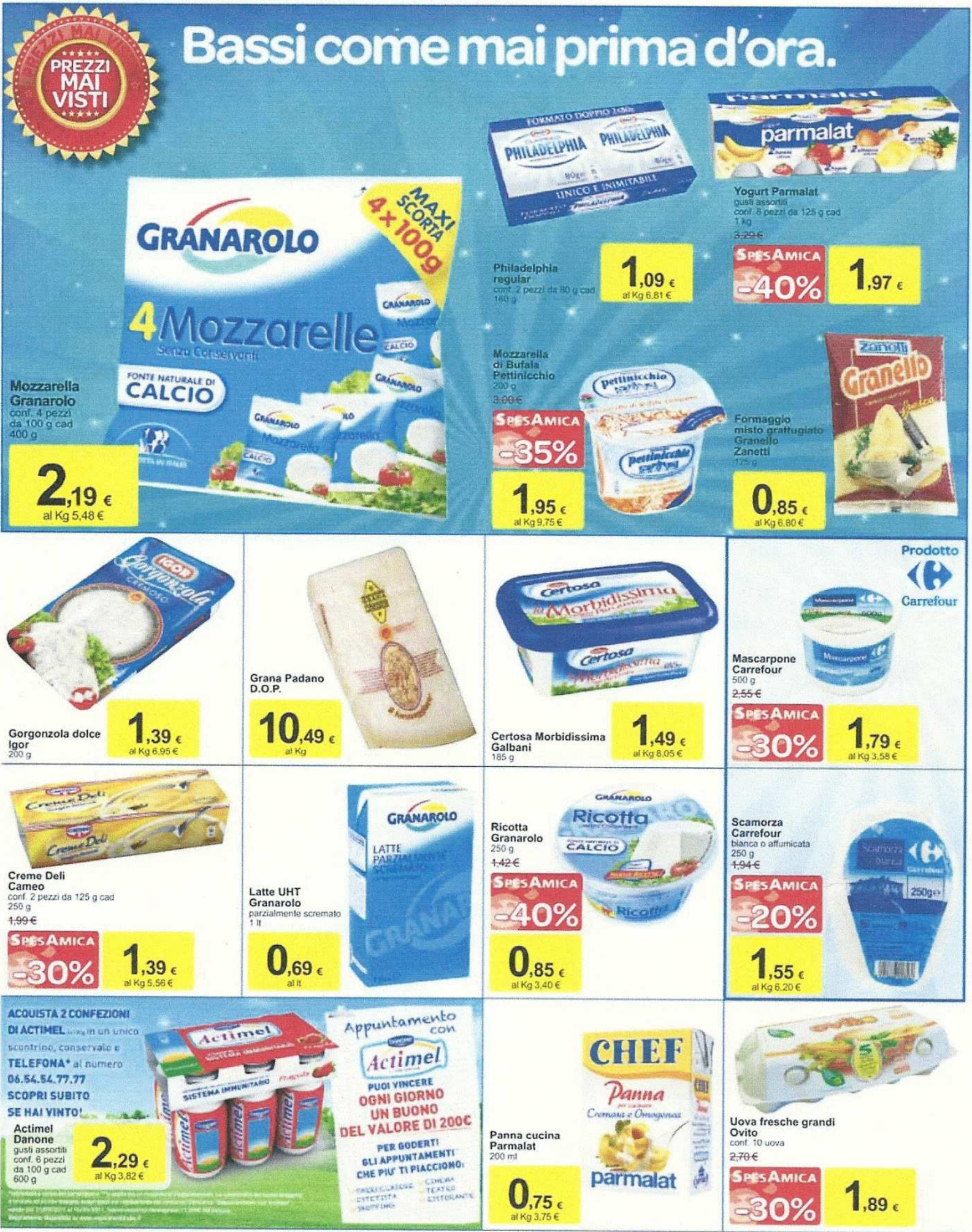

4 wwwcarrefourit Le offerte SpesAmica sono valide peripossessoridi Carta SpesAmica, Carta PASS Carta PASS MasterCard. 


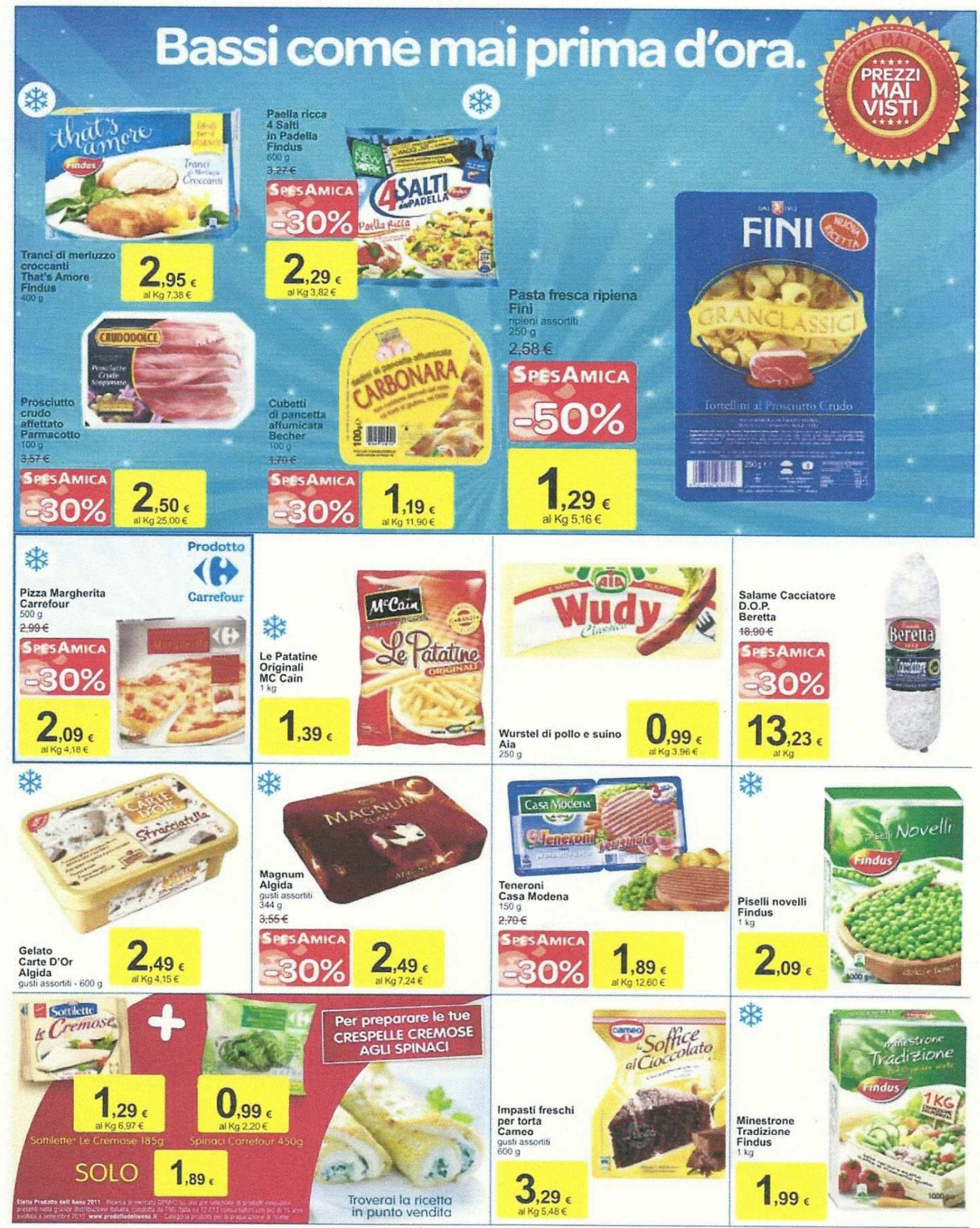

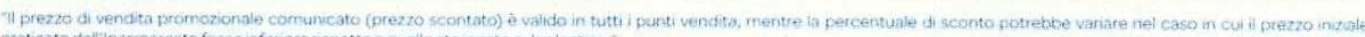
praticato dalli ipermercato fosse infericre rispetto a quelio stampato sul volantino 


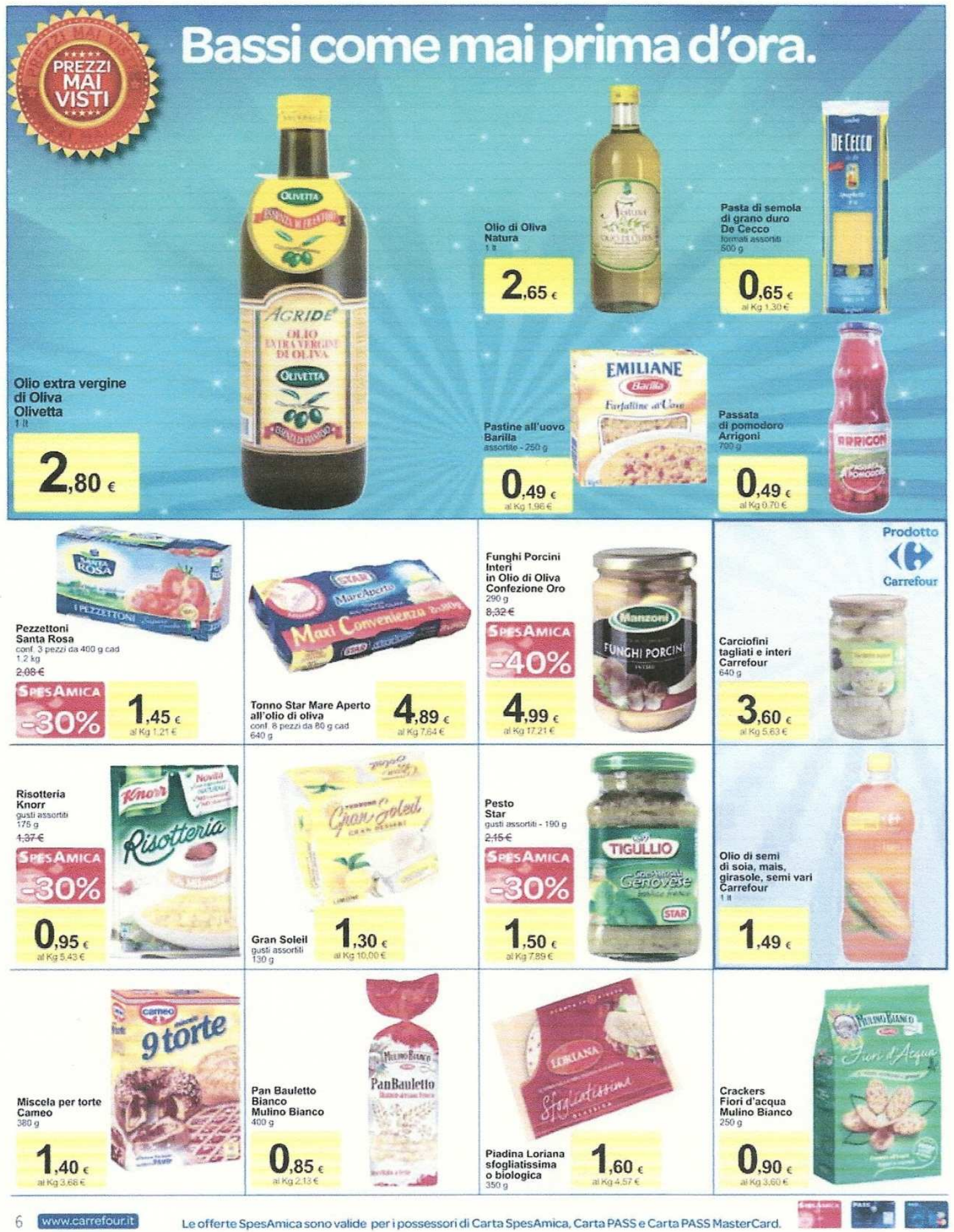




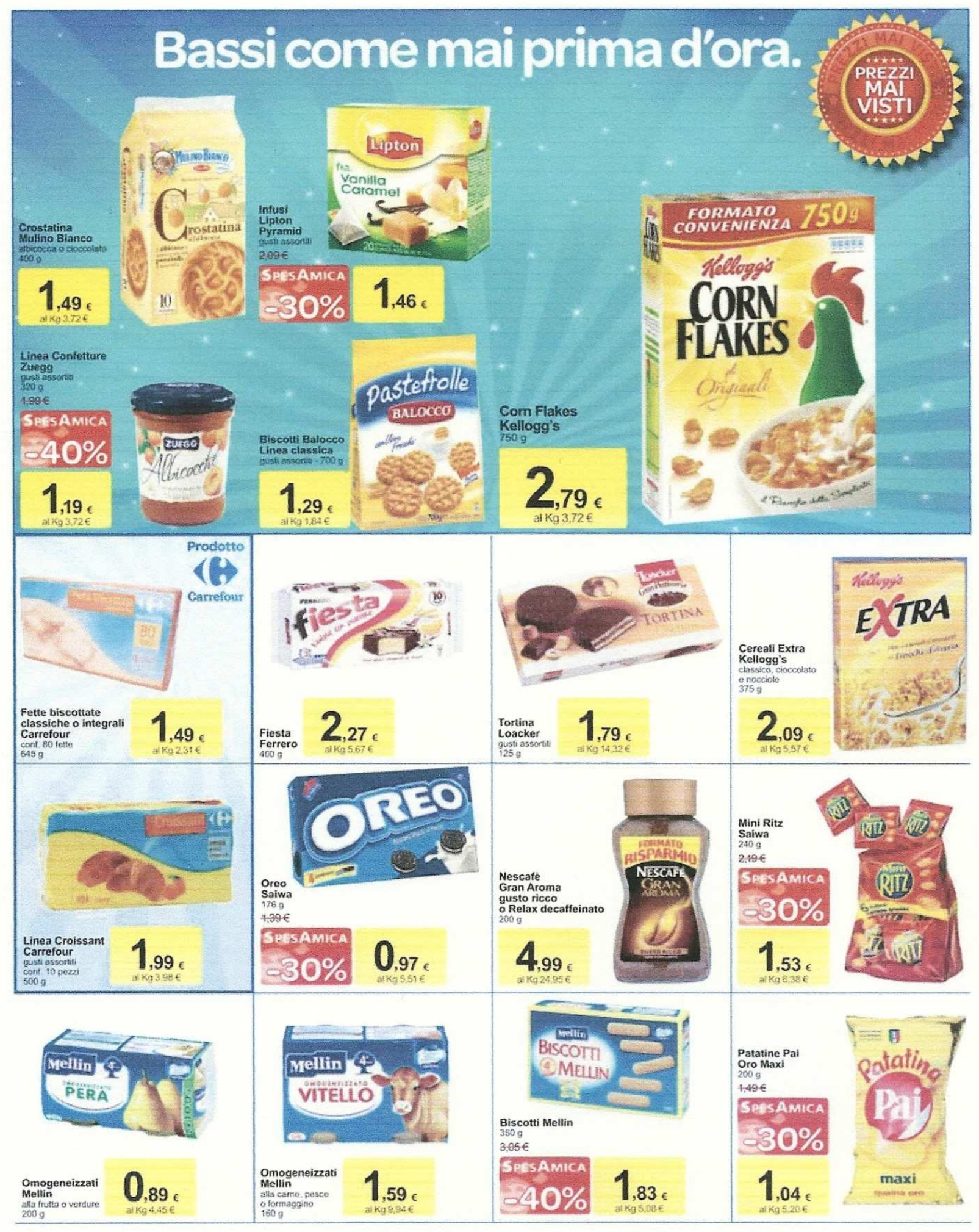

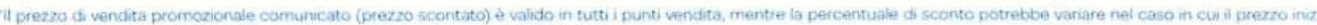
praticato dall' ipermercato fosse inferiorerispetto a guello stampato sul volantino: 


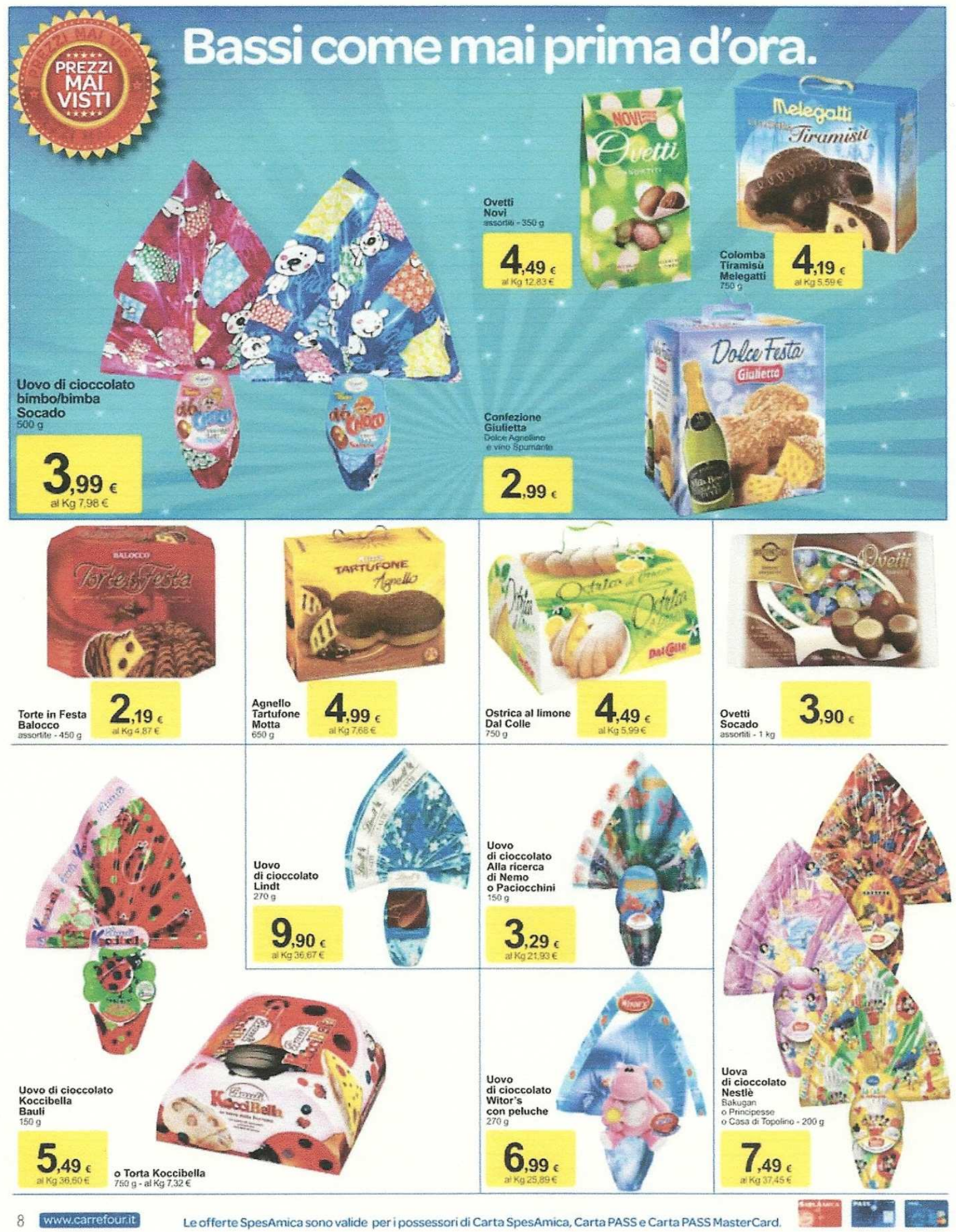




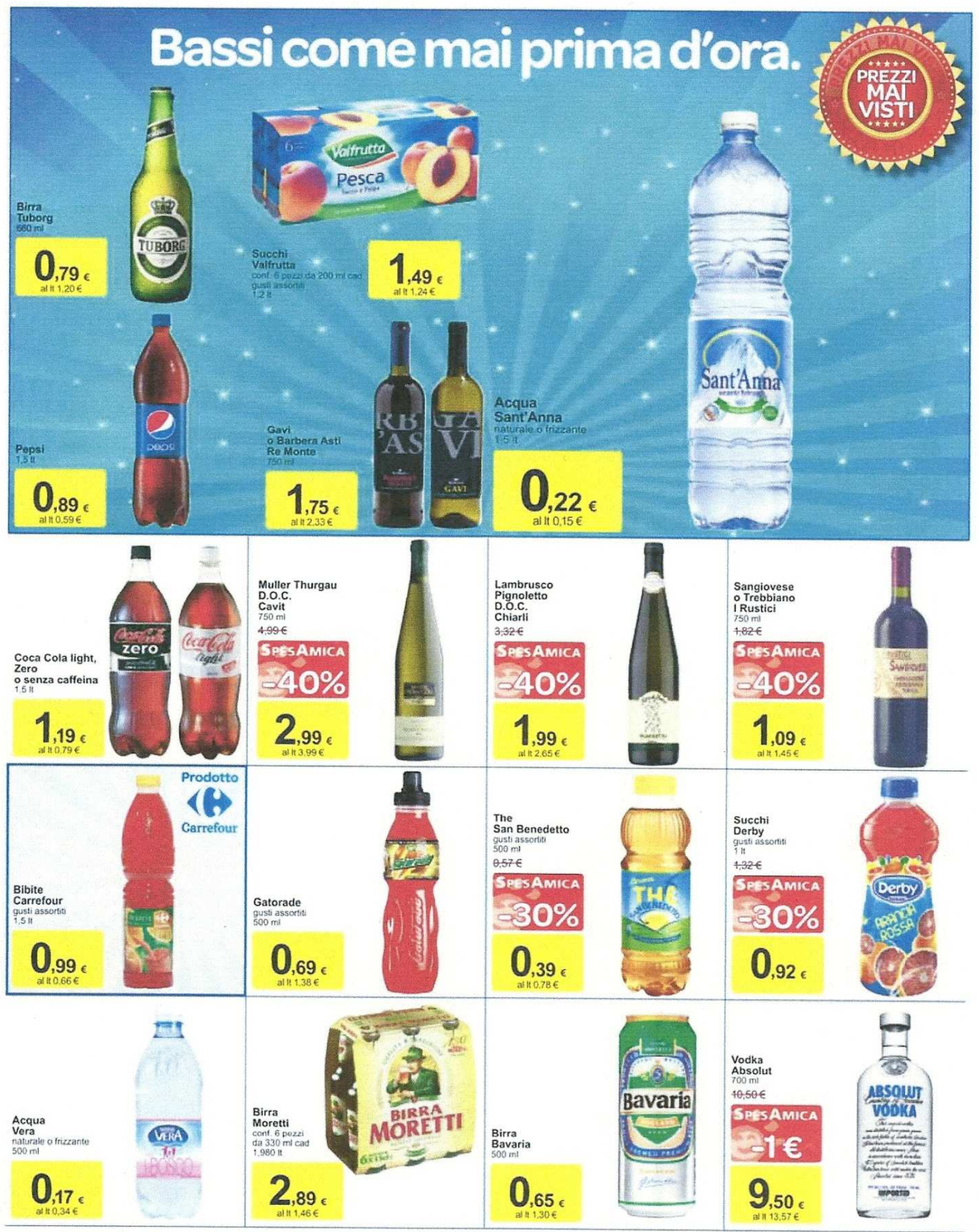

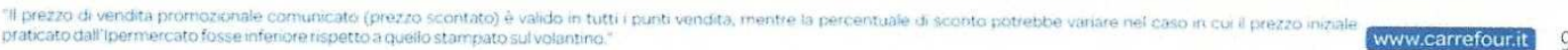




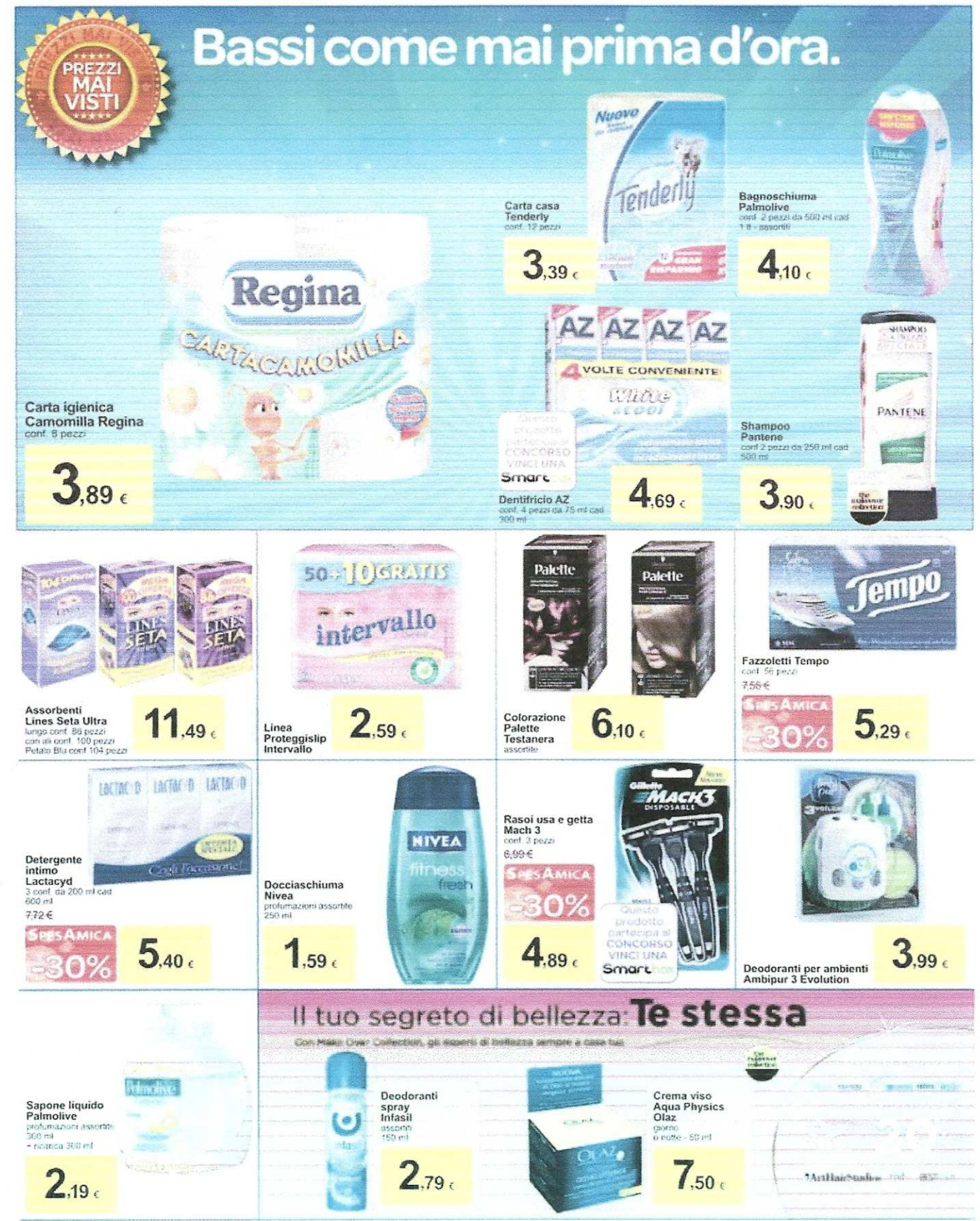

10 WwWcarrefourit Le offerte Spesamica sono valide per ipossessonidi Carta SpesAmica, Carta PASS Carta PASS MasterCard 


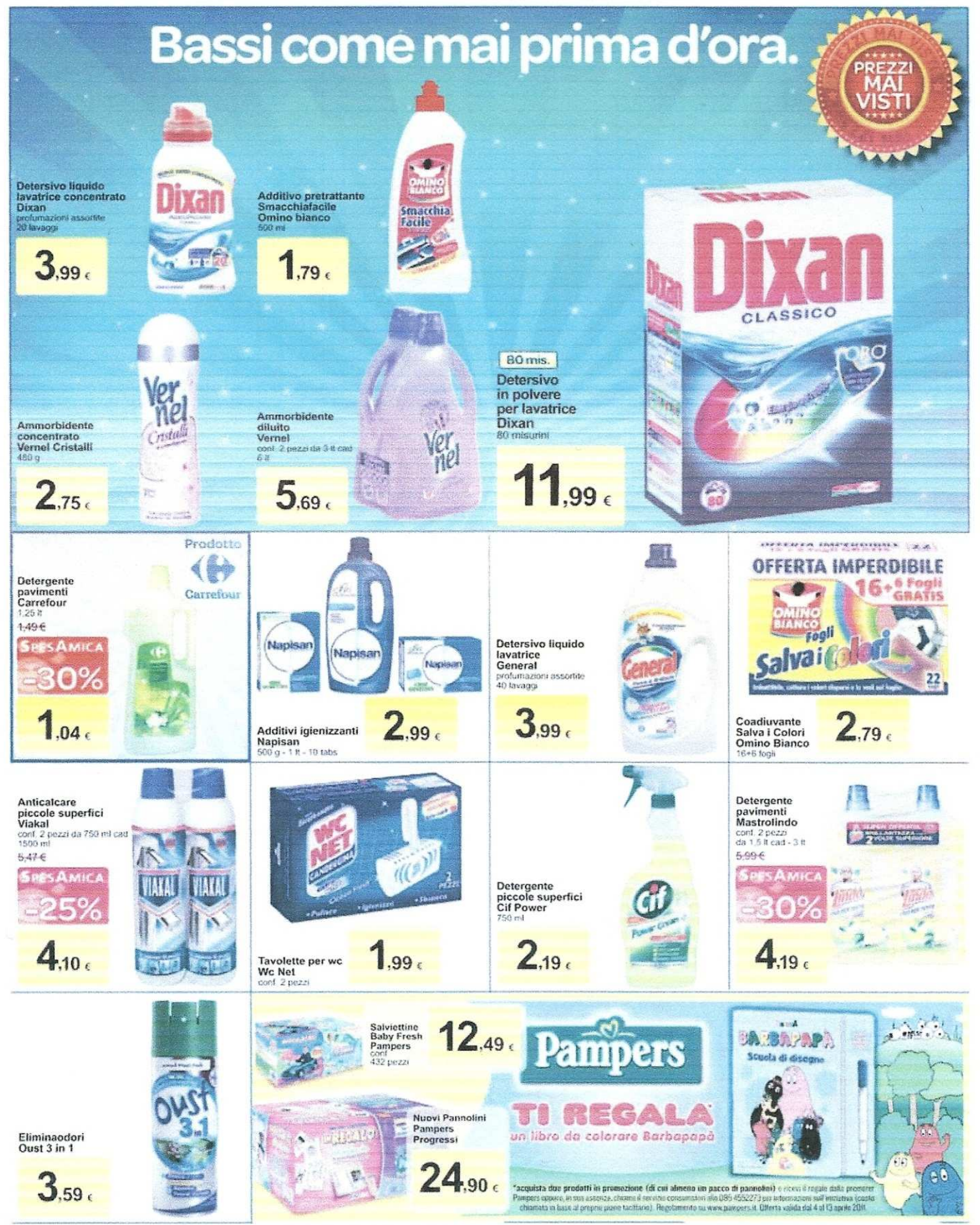




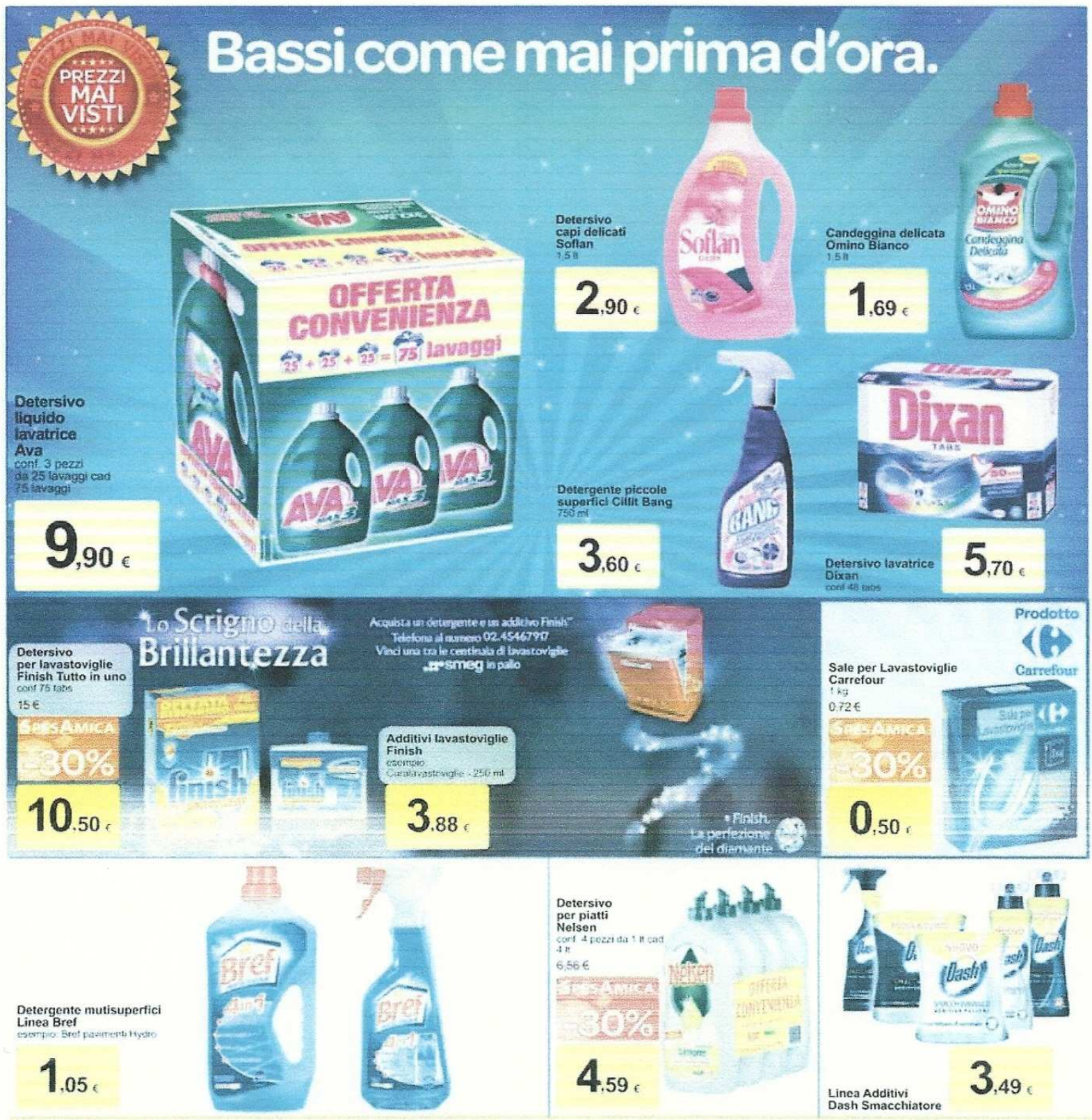

Per i nostri amici animali.

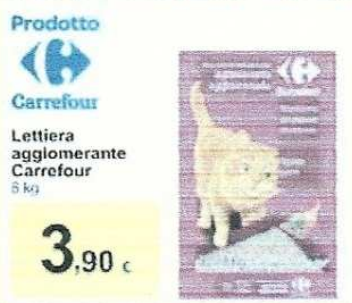

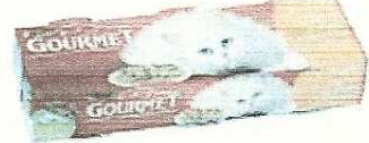

GOURMET.

Alimento per gatti

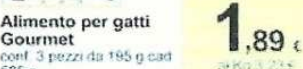

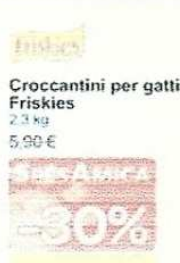

4,13

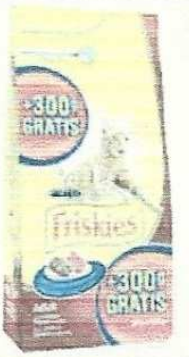

Alimento

per cani
Pedigree

1,99 ,

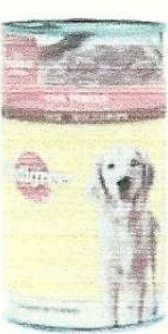

픔 


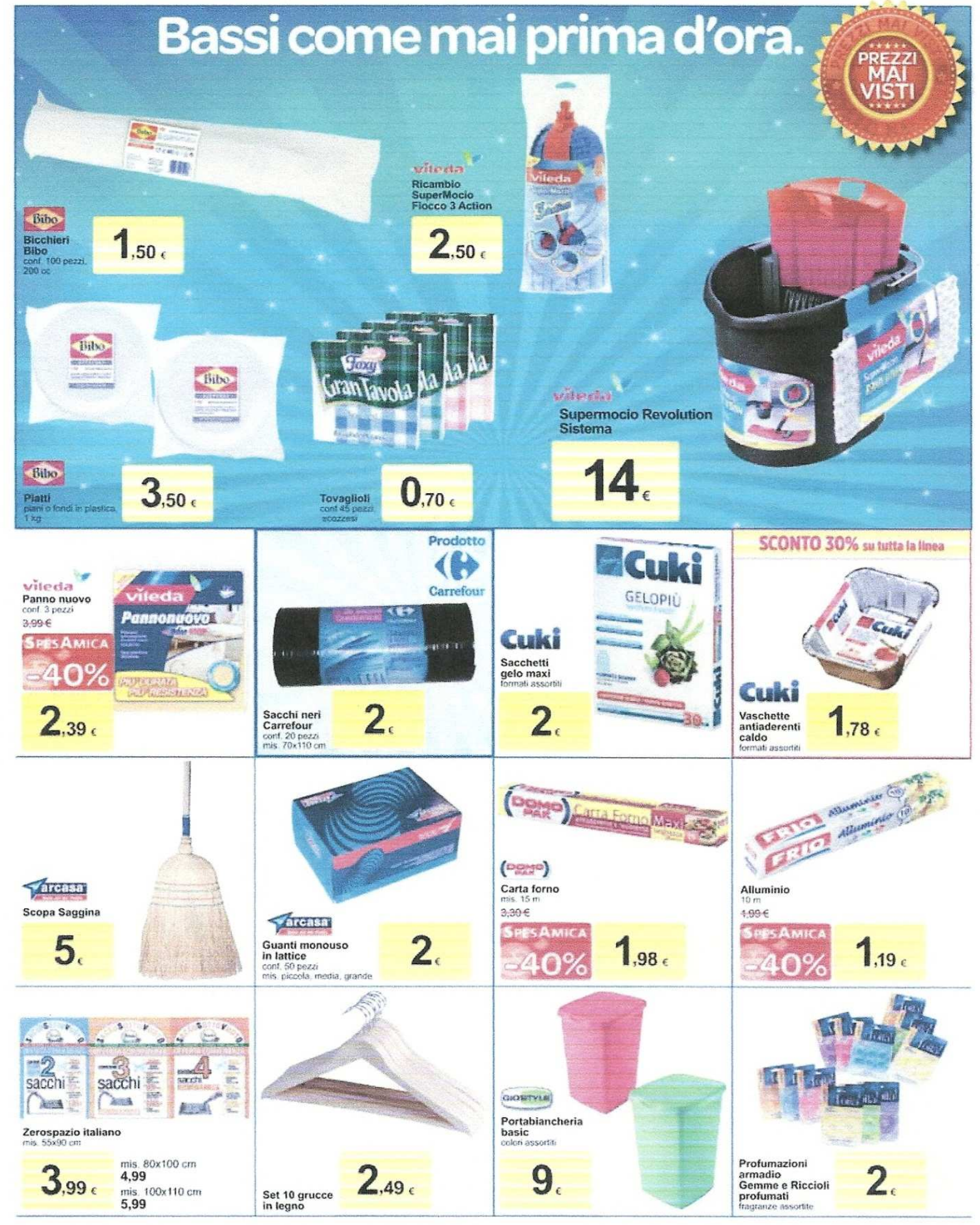



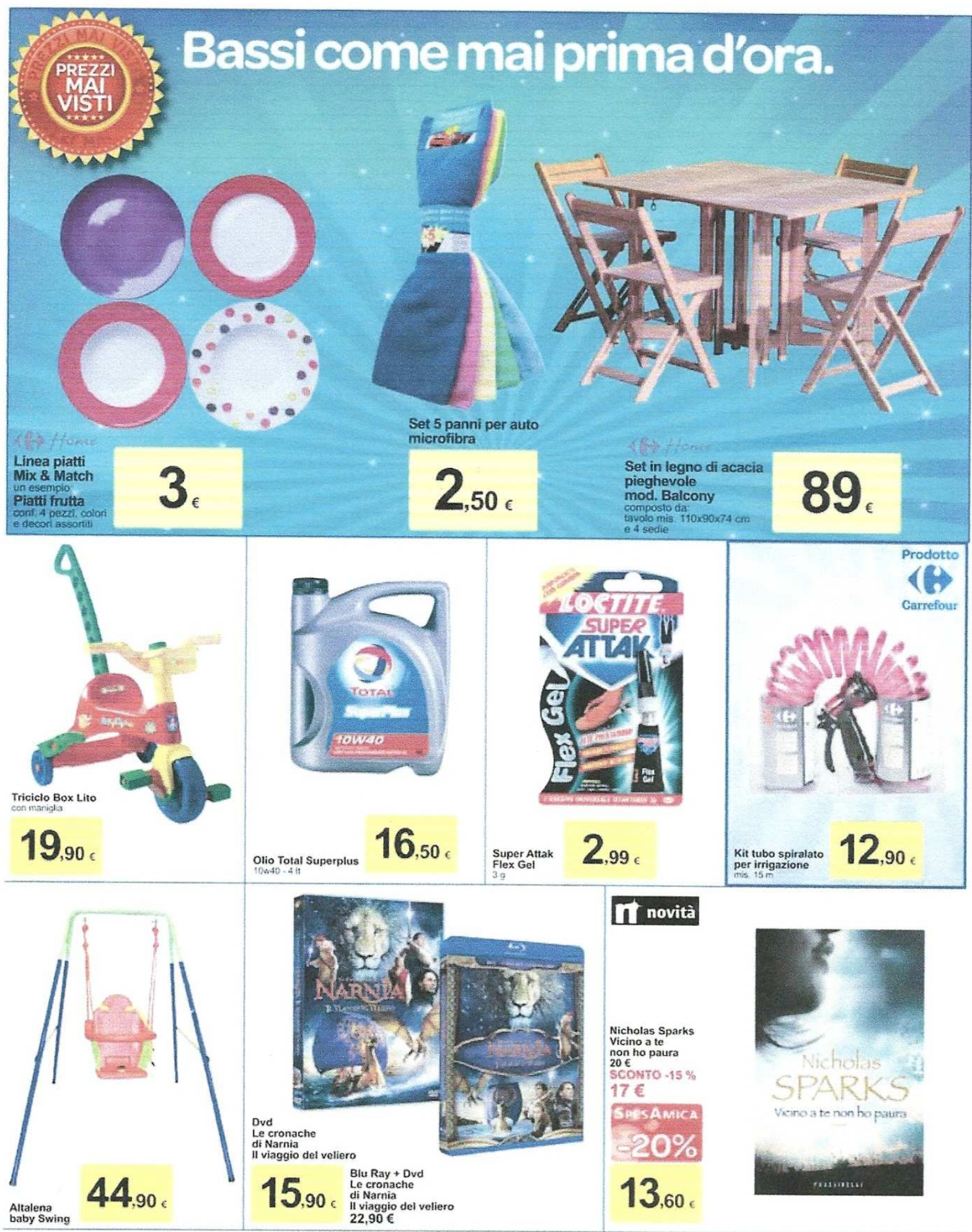

II novità

Nicholas Sparks non ho paura $20 \in$ $17 €$

SRESAMICA $20 \%$ 13.60 。

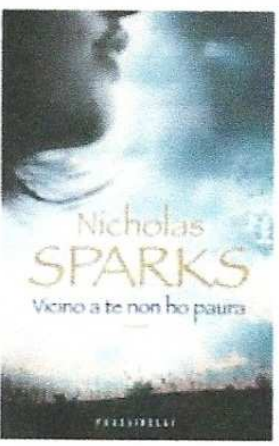

14 wwocarrefourit 


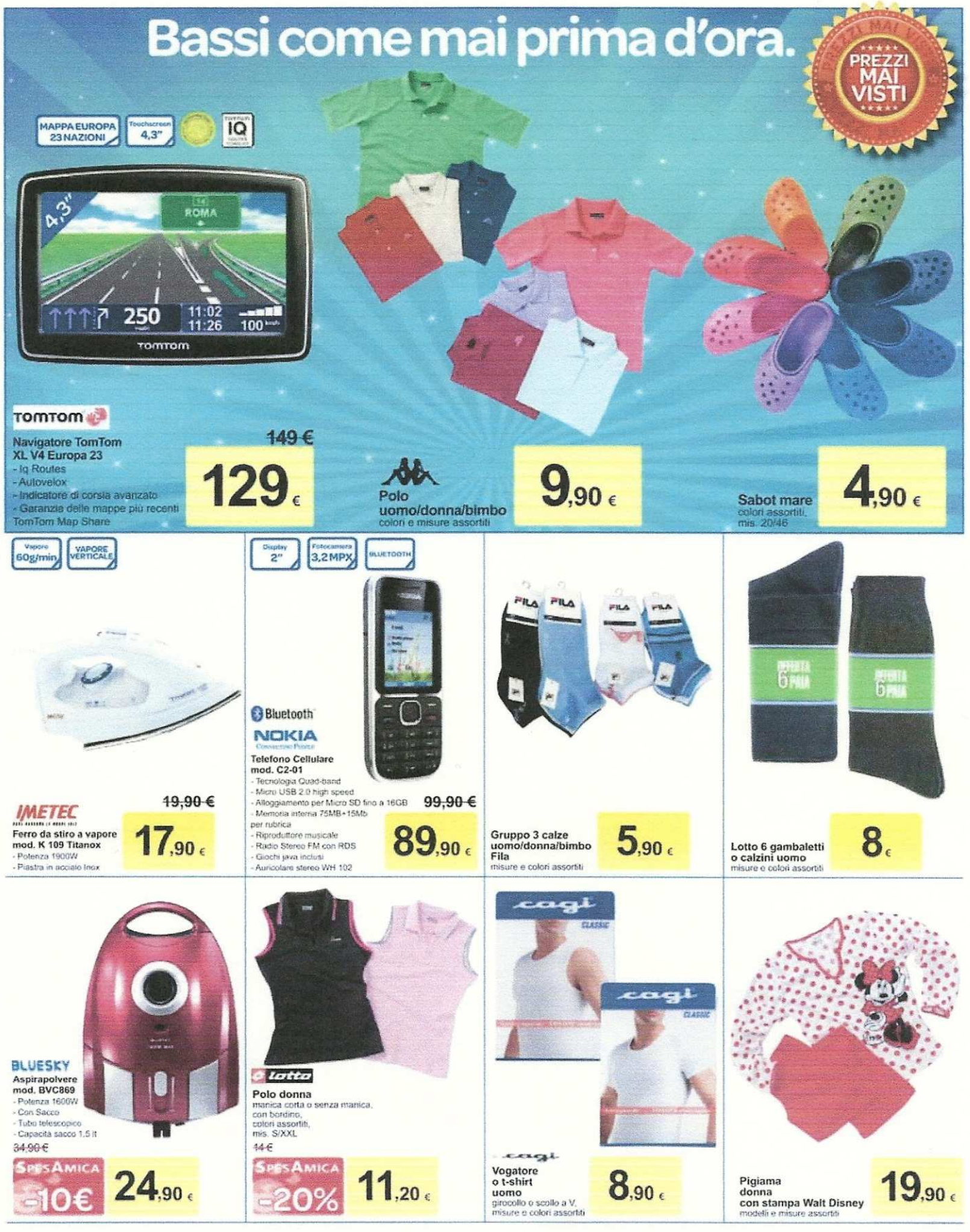




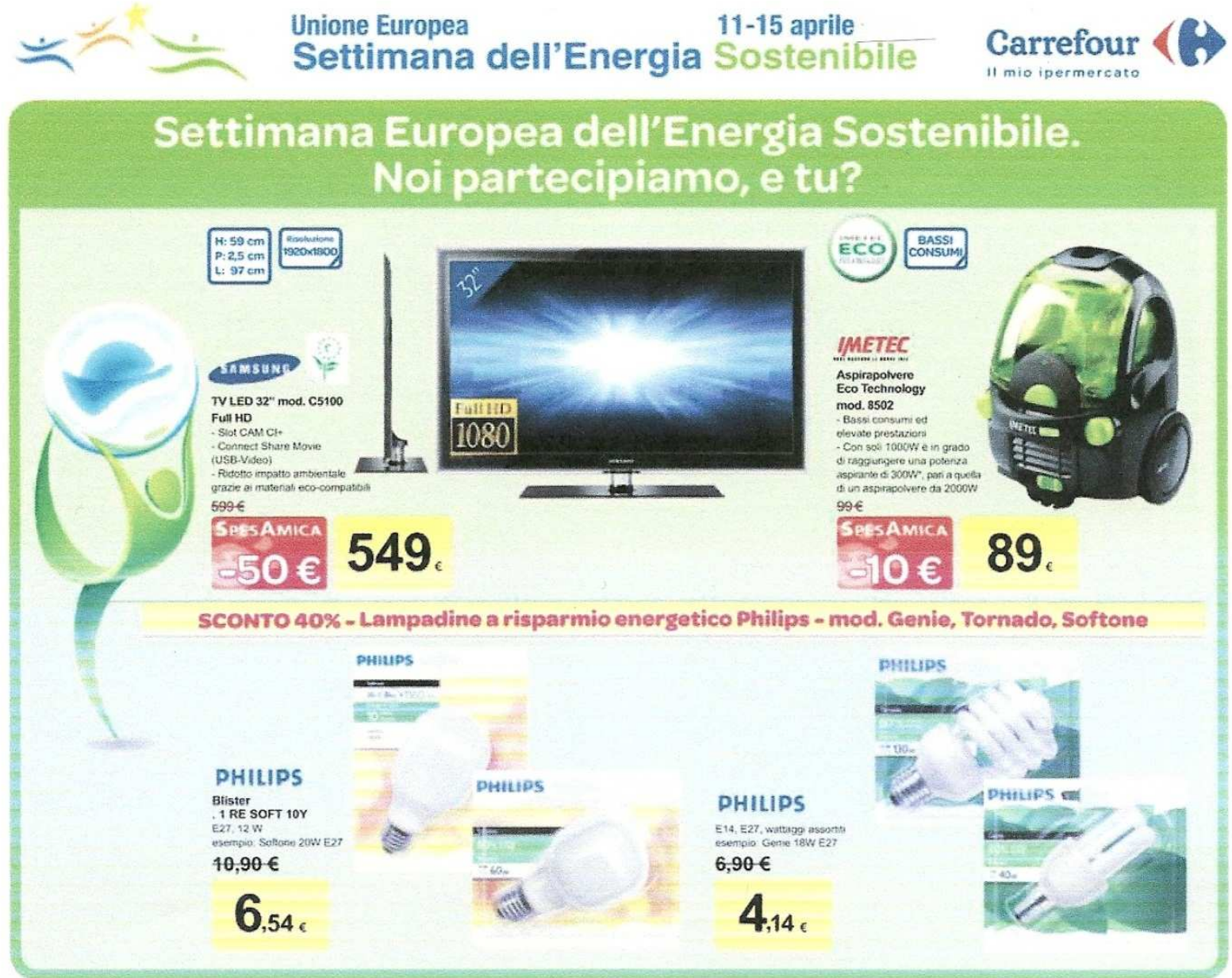

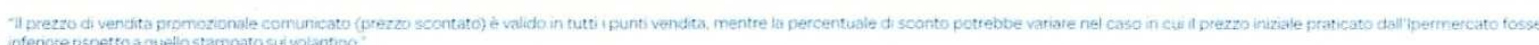

Offerta valida fino ad esaurimento scorte e salvo errori e/o omissioni di stampa le foto sono solo rappresentative - $n^{\circ} 017$ Marzo 201060 lpermercati Carrefour in italia

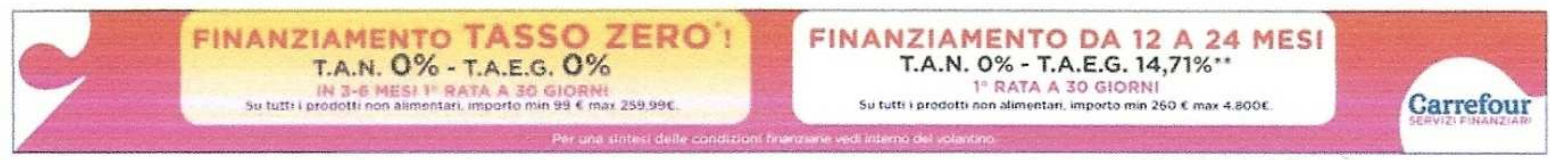

LEOFFERTEDI QUESTO CATALOGO SONO VALIDE NEI SEGUENTIIPERMERCATI LOMBSROA:

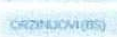
PI.MONT: 


\title{
ANEXO D - PÁGINAS INICIAIS DO LIVRO LUPO ALBERTO. T. V. B. LUPO! - ENTREVISTA A SILVER E DESCRIÇÃO DOS PERSONAGENS DO MUNDO MCKENZIE
}

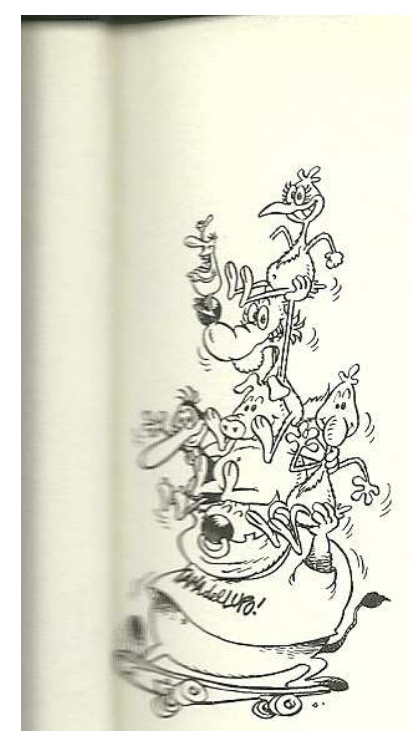

\author{
Il mondo McKenzie: se non ci fosse \\ bisognerebbe inventarlo
}

Più di trent'anni da Lupo non sono certo uno scherzo.

Per capire, uno dovrebbe provarci a dare fiato così a lungo a un personaggio giovane per definizione. Per costituzione.

Giovane perché inossidabile alle delusioni, agli eventi spiacevoli e, perché no, direbbe Mosè, anche alle botte. E che ci piaccia o meno, dobbiamo ammetterlo: Lupo Alberto ne ha prese e ne prende tante. Eppure non c'è verso di togliergli di dosso quell'aria di uno che ci prova ancora, ci prova sempre, almeno fino alle prossime. Le prossime botte, si intende, e delusioni, e ogni altra cosa brutta che gli può capitare di incrociare sulla sua strada, che sia a forma di bastone o di brutture del mondo.

Giovane perché ci crede. Enon serve specificare a chi o a che cosa. Lupo.Alberto ci crede, e basta. Basta che nessuno gli dica in che cosa, di preciso, deve credere.

Di ordini, poi, non se ne parla nemmeno: imposizioni e regole non fanno parte dell'universo di un anticonformista. E che Lupo Alberto sia resistente a qualsiasi tipo di conformismo è provato da due fatti.

Il primo è che il suo autore, quando pronuncia parole conformiste come "anticonformismo", si fa una bella risata, reazione tipica degli anticonformisti veri.

Il secondo è che, sempre il suo autore, insiste nell'affermare che Lupo Alberto è cambiato rispetto a quando appariva in pubblico le prime volte. E, a sentir lui, non si è trasformato solo nell' aspetto ma anche nel carattere: oggi vede le cose in modo più disincantato rispetto al passato. Come dire che non è più il Lupo che si fa beffa dei luoghi comuni, che se la ride delle convenzioni stupide, che difende i principi ma solo quelli grandi, quelli con l'accento sulla seconda i. Come dire che... nessuno ci crede.

Insomma, più di trent'anni da Lupo, con dentro tutto quello che c'è dal 1974 ad oggi, non sono uno scherzo di sicuro.

Uno dovrebbe provarci a creare un mito, per capire che cosa significa averne anche un po' paura. Paura di non sapere che cosa fargli dire, oggi. O che cosa far- 
gli pensare, o che cosa fargli rispondere magari. Perché quando sei un amico, un riferimento, per tanti ragazzi che ti scrivono, devi anche volerli ascoltare i ragaz$\mathrm{zi}$, e saper parlare con loro. E devi essere disponibile a farlo usando la loro lingua, giovane per definizione. Per costituzione.

$\mathrm{E}$ comunque non è facile fare il mito quando vivi in una fattoria, in mezzo a galline, paperi, conigli, maiali e animali vari ed eventuali. A stretto contatto con una talpa, per giunta. Enrico La Talpa, non un rompiscatole qualsiasi.

Non è facile restare un sognatore anche dopo che sei diventato un portamatite, un cappellino, o magari un cartone animato. E succede che quando ti guardano attraverso lo schermo non sei più solo un idealista sognatore anticonformista controcorrente, ma sei anche colorato, e ti muovi, e hai una voce, hai persino una sigla di apertura e di chiusura.

E hai un sito anche, come dire una collocazione, un posto fisso, un luogo dove possono trovarti quando vogliono, persino quando non ne hai voglia tu, persino quando nemmeno tu sai dove sei.

No, quasi trent'anni da Lupo non sono come dirli. Figuriamoci come sono a disegnarli. Tutti i giorni, senza che il tuo mito faccia un angolo di muffa.

$\mathrm{E}$ in quest'epoca di miti sfornati in quantità industriale, succede che un mito resista quando si è costruito da sé, senza bisogno di ricorrere ad artifici e a salotti televisivi.

Succede che un mito si mantenga genuino quando vive in un pezzo di terra a forma di fattoria, il microcosmo McKenzie.

A sentire Silver succede perché lui il Lupo l'ha sudato, respirato, pianto, assorbito, vomitato e ringoiato. Ė bello sentirglielo dire, a parte il "vomitato e ringoiato" naturalmente.

Così com'è bello sentirgli paragonare Lupo Alberto a una gobba, una protuberanza, un'ameba...

Chi conosce la parabola dell'ameba, usata spesso per spiegare il mestiere dello scrivere, sa che cosa significa.

Significa che fabbricare un mito e alimentarlo non è un passatempo, uno sport, un gioco raffinato che si pratica nei momenti di svago. È una fatica nera.

E chi ha una vaga idea di che cosa sia un'ameba, sa anche con quali intenzioni e modi si insedia in un organismo. E capisce perché, a guardarlo bene, il pezzo di terra McKenzie è un mondo vero.

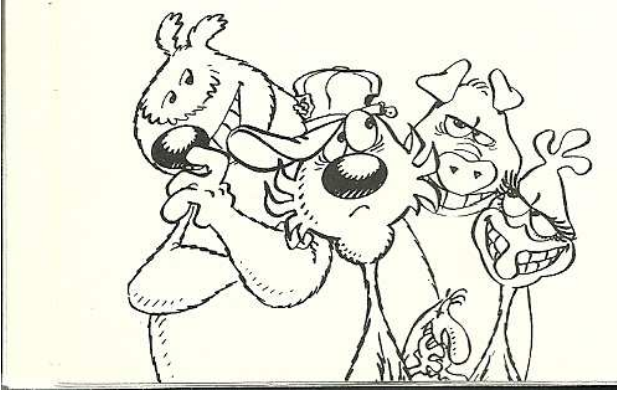

Rosangela Percoco

Direttrice del mensile «Lupo Alberto» 


\section{Intervistando Silver}
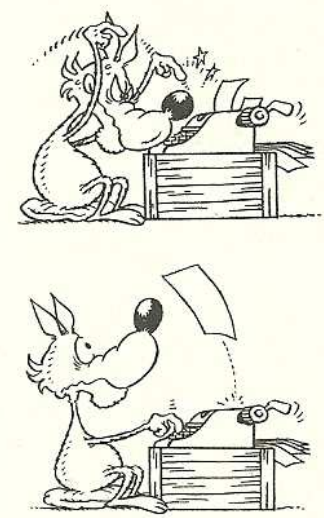

Dove e come è nato Lupo Alberto?

Lupo Alberto è nato a Modena, nel dicembre del 1973. Ma era in gestazione già da tempo, frutto della mia passione per le strips americane e inglesi, e per il cinema d'animazione di Chuck Jones e Tex Avery. Le prime strisce furono pubblicate nel febbraio dell'anno successivo sul «Corriere dei Ragazzi» diretto da Giancarlo Francesconi.

\section{A cosa ti sei ispirato per realizzare Mosè?}

Mosè è un bobtail, cane da pastore inglese, guardiano di greggi. È ispirato a tutti gli ottusi tutori dell'ordine costituito, quelli che servono un sistema senza chiedersi se sia giusto o sbagliato. Ma è ispirato soprattutto a Sam Sheepdog, un esilarante personaggio di Chuck Jones.

\section{Perché il lupo è azzurro?}

Il colore di Lupo Alberto non è una scelta artistica. Innanzitutto Lupo Alberto era nato in bianco e nero, e per diversi anni non si presentò il problema del suo colore. Quando in seguito si trattò di "tinteggiarlo", immaginai che dovesse avere il colore, grossomodo, di un lupo siberiano, grigio con riflessi azzurri. Ma le percentuali di nero e blu erano sempre altalenanti a seconda del tipografo, creando un curioso effetto cangiante. La decisione fu drastica: blu e basta, anzi, sessanta percento di ciano (o Pantone 297).

\section{Perché il lupo ama una gallina?}

Credo nella libertà di amare chiunque, senza limiti di età, sesso, razza, o specie animale, anche se mia moglie è una comune femmina di specie umana. Se poi vogliamo riferirci al fatto che i lupi di solito le galline le mangiano, ebbene, forse in quel lontano inverno di trentasette anni fa ho semplicemente voluto ribaltare l'ancestrale stereotipo del lupo feroce predatore. Ho ammansito un lupo, tutto qua. Non lo aveva già fatto anche san Francesco? 
Cosa consiglieresti a un giovane che vuole fare il fumettista?

Di non fare sciocchezze. La maggior parte per fortuna desiste dall'insano proposito ancora prima di suonare il campanello del tuo studio, e quelle sono le persone che partono col piede giusto, che avranno soddisfazioni dalla vita e successo negli affari. Gli altri vanno incontro a cocenti delusioni, mortificati e scherniti da amici e parenti. Ma dato che ciascuno ha il diritto di impiccarsi come crede, un consiglio lo do volentieri: è quello di copiare, copiare, copiare, disegnare, disegnare, disegnare, fino allo sfinimento, e poi di leggere, leggere, leggere, studiare, studiare, studiare, e non sentirsi mai soddisfatti dei risultati raggiunti. $\grave{E}$ altresì inutile tediare il fumettista affermato: qui grazie a Dio non si va per raccomandazioni. Se hai talento qualcuno te lo riconoscerà. Se non ce l'hai, non ce l'hai. Amen.

\section{Che scuole hai fatto per diventare fumettista?}

Non ho fatto scuole per diventare fumettista. A quei tempi non ce n'erano e se anche ce ne fossero state probabilmente la mia famiglia non avrebbe potuto permettersi la retta, generalmente salata. Io e la maggior parte dei miei colleghi (che come me non hanno frequentato scuole di fumetto) siamo comunque la dimostrazione vivente che non sono necessarie scuole specifiche per approdare a questa professione. È più importante una buona istruzione scolastica e un ricco bagaglio di cultura generale. Oltre che una naturale predisposizione, ovviamente.

Hai sempre pensato di fare il fumettista o avevi altri aspirazioni?

Che io ricordi, sì. Dall'età di dieci-dodici anni non ho fatto altro che sognarmi affermato autore di fumetti. Dedicavo moltissimo tempo a questa mia passione. In precedenza avevo espresso il desiderio di diventare o cuoco o prete. Così almeno mi dicono. Oggi devo ammettere che sarei stato un discreto cuoco.

Qual è il tuo rapporto con Lupo Alberto?

I personaggi dei fumetti barattano la loro esistenza a due dimensioni con l'eterna giovinezza. Nel senso che hanno il grande privilegio di non invecchiare mai. Così se Lupo Alberto poteva essere una mia proiezione trent'anni fa (ma non è detto che lo fosse!), oggi una tale identificazione risulterebbe quanto mai forzata. Diciamo che oggi ho qualcosa in comune più con Enrico la Talpa che con Alberto...

Quando realizzi una tavola pensi prima al disegno o al testo?

Ovviamente al testo. Non mandi gli attori in scena senza un copione.

Fai tutto tu ancora oggi?

Fortunatamente no. Non mi basterebbe disegnare giorno e notte. Per Lupo Alberto lavora un team di professionisti che si occupano della maggior parte del 
materiale che viene sceneggiato e disegnato. Io mi occupo della supervisione di questo materiale, ritagliandomi comunque una parte di produzione che realizzo completamente da me. La cosa buffa è che nemmeno io riesco più a distinguere quello che ho fatto io da quello che hanno fatto i collaboratori. Anzi, tutte le volte che mi congratulo con me stesso per un bel disegno, scopro... che $l^{\prime}$ ha fatto un altro.

Qual è il tuo rapporto con gli sceneggiatori e i disegnatori che ti aiutano nel tuo lavoro? Tra noi c'è familiarità. Non ci vediamo spesso perché tutti i collaboratori sono sparpagliati per l'Italia, dal Piemonte al Lazio all'Emilia al Veneto e via dicendo; ma siamo in costante contatto sia telefonico sia informatico. Poi capita di incontrarci in redazione, oltre che a manifestazioni del settore, fiere e convegni.

Hai mai pensato di realizzare altri personaggi?

Ho un cassetto pieno di nuovi personaggi. Ma Lupo Alberto esige da me tutta l'attenzione. Perciò temo che prima o poi mi toccherà comprare un altro cassetto.

Come è la tua giornata tipo?

Mi alzo alle sette; accompagno le figlie a scuola; vado in ufficio; mi occupo delle cose dell'ufficio; faccio qualche telefonata; vado agli appuntamenti, se ho degli appuntamenti; pranzo, possibilmente con mia moglie se non ho colazioni di lavoro; torno in ufficio; a volte esco prima per andare al supermercato, oppure metti che devo andare dal dentista... mondanità poca.

Si dice che tu assomigli a Lupo Alberto e non solo fisicamente: cosa rispondi?

Un mio vecchio insegnante di disegno mi dimostrò come ogni volta che crei qualcosa ci metti sempre qualcosa di te. Fece disegnare a tutta la classe una figura umana, di fantasia, ma molto particolareggiata. $\mathrm{Be}^{\prime}$, ne uscì un divertente esperimento: chi aveva ad esempio mani tozze e grassocce aveva disegnato, senza volerlo, mani di quel genere, e così via per chi aveva figure longilinee o tarchiate, nasi pronunciati, gambe lunghe o corte... Diversamente da tanti colleghi che per narcisismo (o più semplicemente per la comodità di un modello sempre disponibile!) si autoritraggono nei personaggi a cui danno vita, io non ho cercato di dare le mie sembianze a Lupo Alberto. Ciononostante e mio malgrado Lupo Alberto mi somiglia. Che ci posso fare?

Ti senti più bravo come disegnatore o come sceneggiatore?

Non mi ritengo un bravo disegnatore. E neanche un grande sceneggiatore. Semplicemente penso che quello che scrivo e che disegno si armonizzino in modo da essere qualcosa che va oltre l'esercizio letterario o il virtuosismo artistico fine a se stesso, per diventare qualcosa di diverso: fumetto.

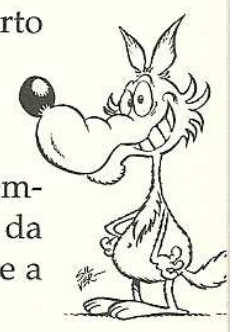


Quale personaggio dei tuoi è il tuo preferito e perché?

I propri personaggi si amano un po' tutti, e tutti in modo diverso, come figli. Ad alcuni ci sentiamo più vicini in certi momenti, di altri si amano alcuni aspetti del carattere. Se da giovane potevo solidarizzare con Lupo Alberto, così recalcitrante agli obblighi sociali, oggi avverto maggiori affinità con Enrico la Talpa, accomodante, irrequieto ma sazio. E quando in casa strillo (sono un papà severo!) $\mathrm{mi}$ sento un pochino Mosè.

Qual è per te la ragione del successo di Lupo Alberto?

Me lo sono chiesto spesso anch'io, poi ho smesso di farlo. Tanto è inutile. Si possono individuare mille ragioni, e altre mille opposte. Se sostenessi che si è trattato soltanto di un immeritato dono della dea bendata, nessuno avrebbe dubbi su una tale affermazione. Lo stesso se dicessi che il merito è da attribuire a una sofisticata e cinica operazione di marketing.

Quali sono i personaggi e gli autori che preferisci (a parte i tuoi ovviamente)?

Rispondendo a domande di questo genere si finisce inevitabilmente per fare torto a qualcuno. Magari a un bravo collega, o a un giovane talento emergente di cui colpevolmente ignoriamo il lavoro. Quindi mi limiterò a citare gli autori e i personaggi che mi hanno influenzato in gioventù. Dico subito che il primo è stato Jacovitti, che mi rammarico di non aver mai incontrato personalmente, avendone avuto l'opportunità, preso da un ridicolo attacco di timor panico. Poi sono venuti gli americani, come George Herriman con Krazy Kat, Shulz e i suoi Peanuts, l'amatissimo Pogo di Walt Kelly, cresciuto alla Disney. Per l'animazione non posso non citare il "prozio" di Lupo Alberto, Wile E. Coyote di Chuck Jones, e poi Tex Avery, e tutta una serie di autori e personaggi della Warner. E vogliamo tacere di Will Eisner? Se a qualcuno alcuni di questi nomi risultassero ostici, gli consiglio di cercarli in fumetteria. Ne vale la pena.

Talvolta usi il lupo per importanti campagne sociali: perché?

Prima di tutto perché me lo chiedono. Se poi il tema della campagna è di quelli che mi coinvolgono, aderisco subito con entusiasmo, e sempre gratis! Penso che chiunque goda di un minimo di popolarità e di credito presso un pubblico più o meno vasto, abbia il dovere morale di spenderne una parte per contribuire al miglioramento della società.

Qual è il tuo rapporto con i lettori?

Dagli inizi della mia carriera ho sempre dato una grande importanza alla comunicazione con il mio pubblico di lettori. Molti li ho incontrati, e li incontro, durante i numerosi dibattiti e conferenze nelle scuole o semplici performance in librerie e cartolerie cui prendo parte. Ma soprattutto ho sviluppato questo aspet- 
to attraverso una rubrica di posta che trova spazio da ormai vent'anni sul mensile «Lupo Alberto». Più di recente è stato realizzato anche un sito per estendere alla rete il dialogo con i lettori. E i tanti amici che ci scrivono sanno che non si tratta mai di futili argomenti. Sulle lettere a Lupo Alberto è stato scritto perfino un libro, che può collocarsi a buon diritto tra i più seri documenti sulle problematiche giovanili.

Cosa fai nel tempo libero?

Tempo libero $d a \cos a$ ? La mia è una professione che coinvolge a tal punto ogni aspetto della vita, che è già tanto che abbia trovato una compagna disposta a condividere con me quella che io considero una forma morbosa di esistenza. Non c'è stacco. Non ci si può calare con lo scafandro nelle profondità metafisiche della fattoria McKenzie alle otto di mattina per poi riemergerne come se nulla fosse alle sei di.sera. Qualcosa ti rimane attaccato addosso. E ti condiziona. Il tempo libero per me è quello che umanamente non posso, non posso, negare alla mia famiglia.

Quali sono, secondo te, gli ingredienti principali necessari per realizzare un buon fumetto comico?

Essere dotati di un innato senso dell'umorismo è fondamentale. L'innato senso dell'umorismo si può esprimere attraverso il disegno, la scrittura, la recitazione, la mimica. Ma da qualche parte deve uscire. Se non esce non sei un umorista. Non è poi così grave...

Come ti è venuto in mente il nome di Lupo Alberto?

Era il 1973. Nel tentativo di sfuggire alla consuetudine che voleva i personaggi dei fumetti, soprattutto se animali antropomorfizzati, dotati di nomi idioti, quali Pik\&Pok, Lupo de Lupis, Pico de Paperis, Yoghi, Bubu e compagnia bella, decisi di dare ai miei personaggi dei nomi normali, anzi, un pochino pretenziosi, quasi aristocratici. Alberto, per un lupo, mi sembrava esilarante. Marta, per una galli$\mathrm{na}$, il riconoscimento di una dignità fino ad allora negata a queste fedeli ovaiole. E così gli altri: Alfredo, Enrico, Lodovico e il biblico Mosè...

\section{Alberto e Marta si sposeranno?}

Certo che si sposeranno. Il giorno in cui si sposeranno Minni e Topolino, Paperina e Paperino, Olivia e Braccio di Ferro...

Perché alla fattoria McKenzie non ci sono umani? Vedremo mai i signori McKenzie?

Gli animali della fattoria McKenzie rappresentano già le varie tipologie antropologiche. Il signor Mckenzie c'è, è un essere umano, esiste da qualche parte, è lui il padrone, ma non abbiamo bisogno di vederlo. Non sarebbe che un doppione di Mosè. Così come nei Peanuts non vediamo gli adulti, che non sarebbero altro 
che una inutile replica del mondo infantile di Charlie Brown e compagni. Lì sono i bambini che interpretano il mondo degli adulti, così come in Lupo Alberto sono gli animali a interpretare le debolezze umane.

Quanti anni ha Lupo Alberto?

Io gli ho dato forma nel 1973. Ha visto la luce (è stato pubblicato la prima volta!) nel 1974. Fai i conti... Se invece vogliamo attribuirgli una virtuale età anagrafica, diciamo che potrebbe avere intorno ai venticinque anni, va bene?

Chi è Lupo Alberto?

Lupo Alberto è tutto ciò che vorremmo essere e tutto ciò che non vorremmo essere. Siamo noi. Sei tu.

Per disegnare le tue strisce a cosa ti ispiri?

La famosa ispirazione. Una volta erano le muse a ispirare artisti, poeti, musicisti. E oggi? Oggi più prosaicamente l'ispirazione è frutto di osservazione, capacità di ascoltare, di annotare dati ed elementi della vita reale. Le persone che mi stanno intorno sono le mie muse.

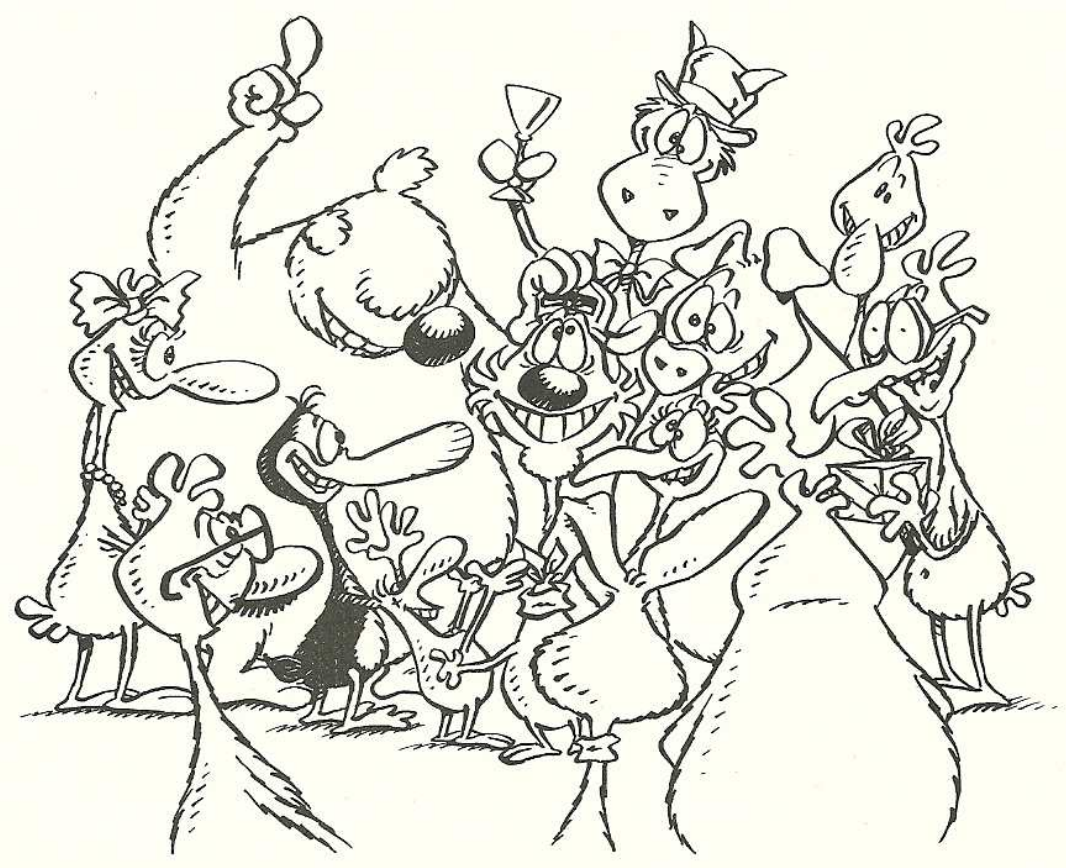


I personaggi del mondo McKenzie

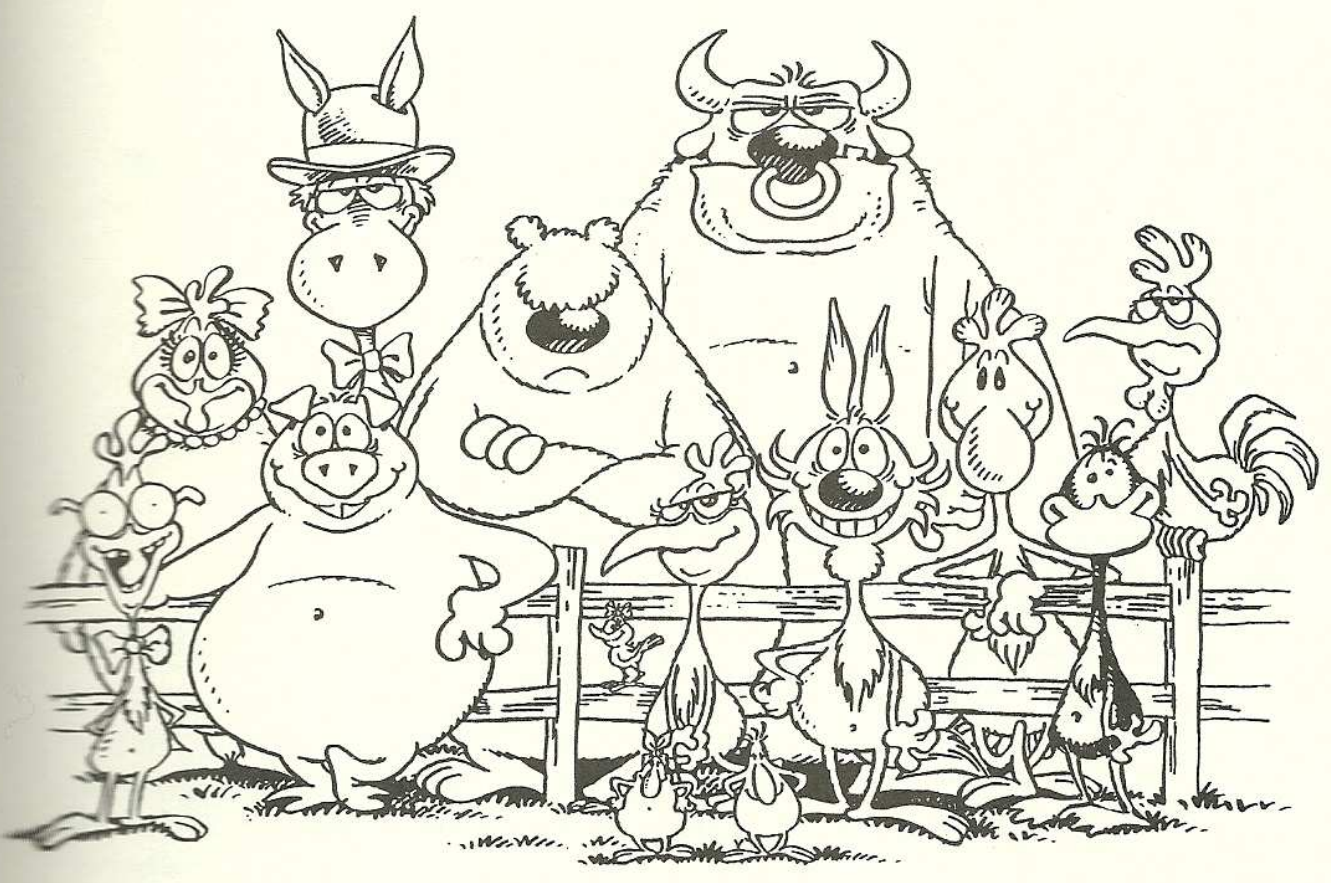




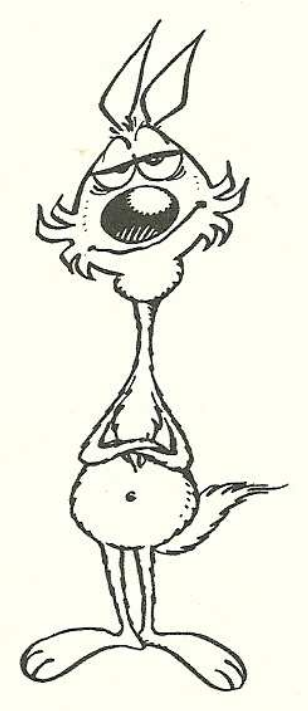

\section{LUPO ALBERTO}

È tranquillo, simpatico e con un forte senso dell'amicizia e della solidarietà. Assolutamente pacifico e pacifista e, per questo, nella sua sfida con l'irascibile Mosè, destinato allo scontro e predestinato alla sconfitta. Vive da solo, indipendente da tutto e da tutti. È libero, pur da eterno fidanzato di Marta, di fare, di pensare e di immaginare la vita che più gli piace.

\section{ALCIDE, il maiale}

È il filosofo, l'intellettuale del gruppo, benché non si sottragga a umili fatiche. I suoi sermoni sono accettati con bonaria tolleranza, ma il suo animo sensibile è messo spesso a dura prova dagli scherzi crudeli di Glicerina.

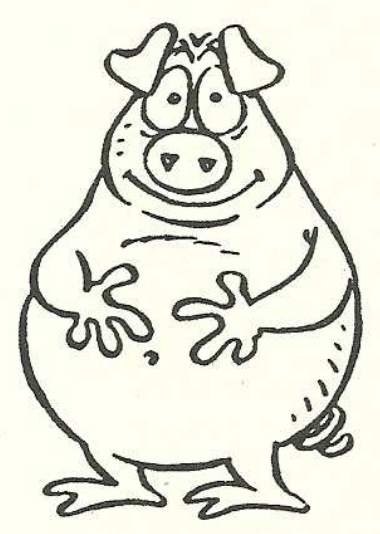




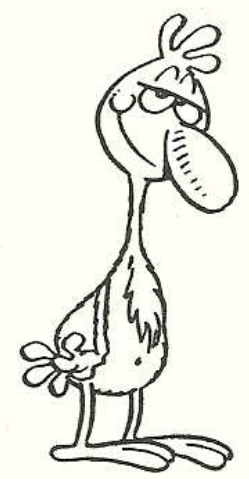

ALFREDO, il tacchino

Alfredo è un personaggio eclettico, si dedica a svariate quanto strambe attività e si intende di meteorologia, di fisica e rabdomanzia. Importante: a Natale, non invitatelo a pranzo...

ALICE, inseparabile amica di Marta

Femminista vecchio stampo, ${ }^{*}$ fruttò al suo autore dure reprimende da parte dello "zoccolo duro" del movimento femminista. Alle nuove generazioni l'ardua sentenza...

*Più per necessità che per vocazione!...

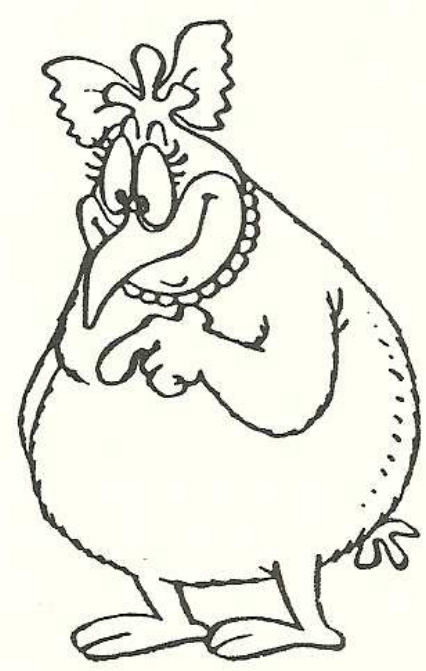




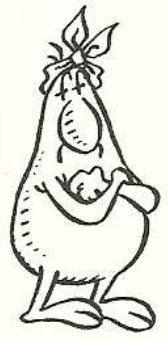

CESIRA, la moglie di Enrico

Assennata e giudiziosa. In parole povere, una rompiscatole. Cucina divinamente.

ENRICO, la talpa

Che dire? Enrico la Talpa è Enrico la Talpa, mica uno qualsiasi. Forse è un po' cialtrone e invadente, ma senz'altro uno speciale.

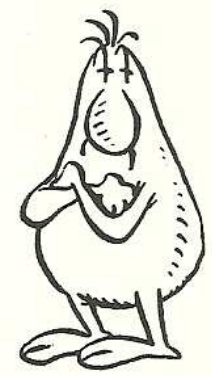




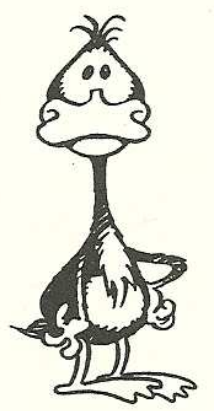

KRUG, il toro

Irascibile e manesco, è l'incarnazione della forza bruta. Disturbarlo durante il sonno rappresenta per tutti un pericolo mortale. Persino il coriaceo Mosè gli gira alla larga.

Detesta gli scherzi.

\section{JOSEPH, il papero detto GLICERINA}

È l'animale più ottimista e sciocco della fattoria. Il suo inguaribile ottimismo è frutto di una ignoranza sconfinata e di una totale inconsapevolezza. Privo di morale, gode sadicamente nel ferire la spiccata sensibilità dell'inseparabile compagno Alcide, il maiale. 


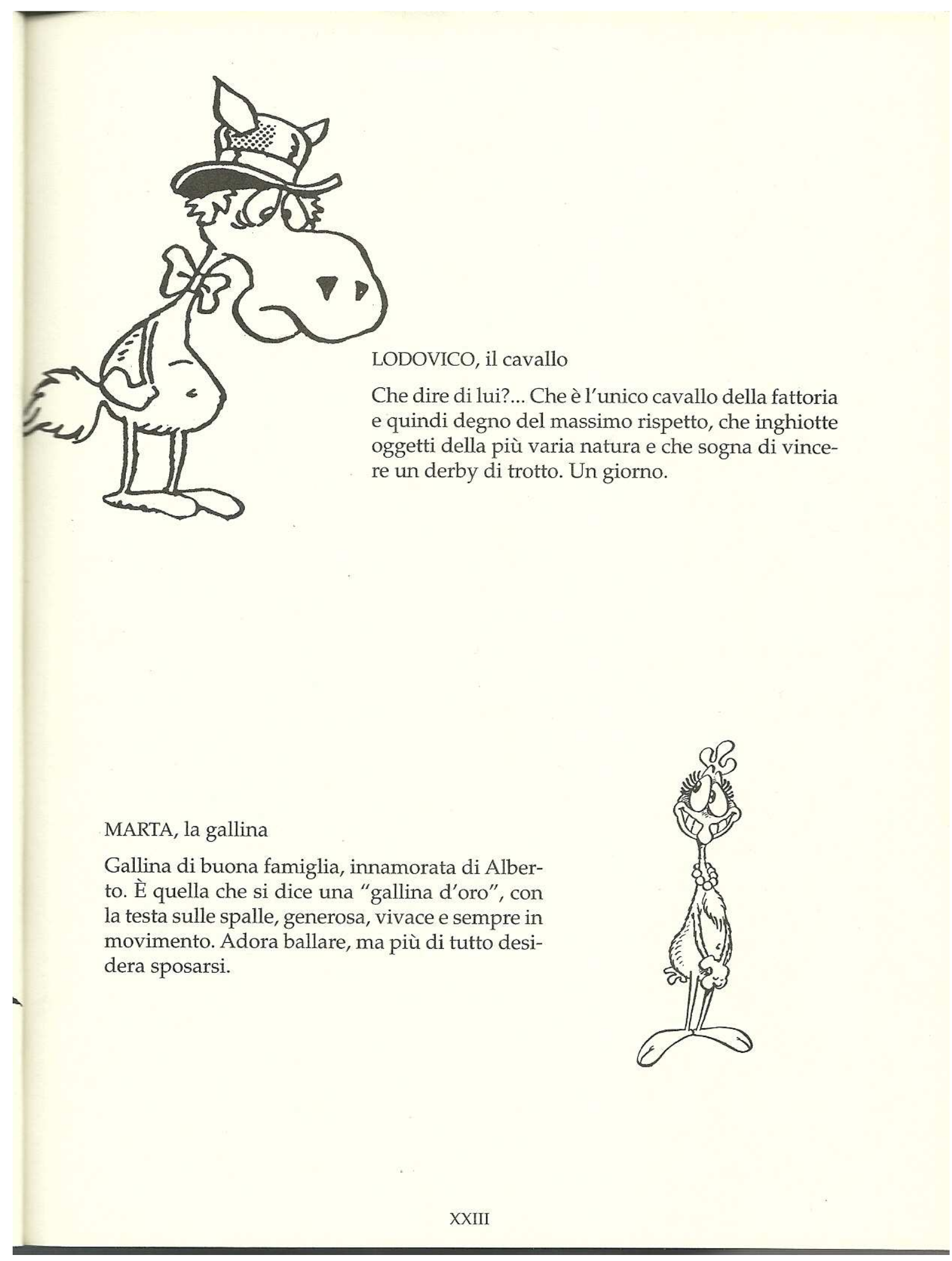




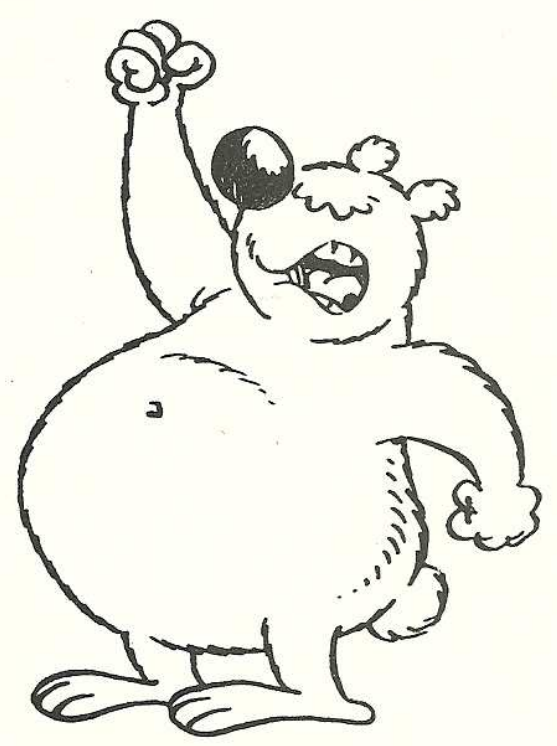

MOSĖ, il guardiano

Paladino dell'ordine costituito, Mosè è l'irriducibile osteggiatore dell'amore tra Alberto e Marta. Serve da sempre un padrone senza chiedersi il perché, proprio come ogni essere umano. Non scambiatelo per un orso!

ODOARDO, il cugino di Marta

Gallinaceo di città, si distingue per inadeguatezza e antipatia. È il tipico primo della classe, il secchione che noi tutti odiamo.

E per giunta ricco!

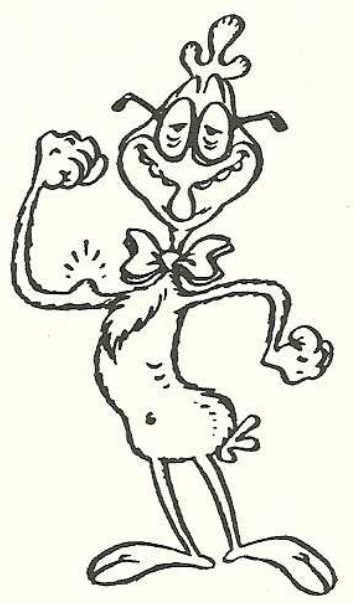




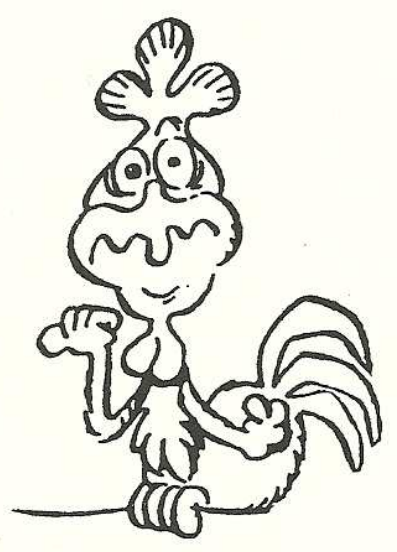

OMAR, il gallo

Dare la sveglia la mattina è il suo unico compito, ma proprio questo è la fonte della sua nevrosi.

\section{SILVIETTA, la passera scopaiola}

Silvietta, con la sua aria da adolescente graziosa, arrivata alla fattoria non si sa come, vi ha subito portato un'ondata di scompiglio. Si rivela invece studentessa zelante, indifferente alle avances di Enrico, le cui fantasie si scatenano ogni qual volta ha occasione di un approccio.

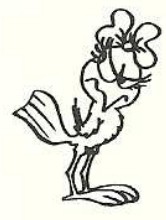

